\title{
Fracture Toughness and Crack Growth Rates of Irradiated Austenitic Stainless Steels
}

Manuscript Completed: March 2003

Date Published: August 2003

Prepared by

O. K. Chopra, E. E. Gruber, and W. J. Shack

Argonne National Laboratory

9700 South Cass Avenue

Argonne, IL 60439

W. H. Cullen, Jr., and C. E. Moyer, NRC Project Managers

Prepared for

Division of Engineering Technology

Office of Nuclear Regulatory Research

U.S. Nuclear Regulatory Commission

Washington, DC 20555-0001

NRC Job Code Y6388

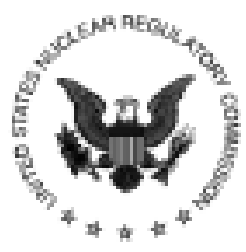




\title{
Fracture Toughness and Crack Growth Rates of Irradiated Austenitic Stainless Steels
}

\author{
by
}

\author{
O. K. Chopra, E. E. Gruber, and W. J. Shack
}

\begin{abstract}
Austenitic stainless steels (SSs) are used extensively as structural alloys in the internal components of reactor pressure vessels because of their superior fracture toughness properties. However, exposure to high levels of neutron irradiation for extended periods leads to significant reduction in the fracture resistance of these steels. Experimental data are presented on fracture toughness and crack growth rates (CGRs) of austenitic SSs irradiated to fluence levels up to $2.0 \times 10^{21} \mathrm{n} / \mathrm{cm}^{2}(\mathrm{E}>1 \mathrm{MeV})(3.0 \mathrm{dpa})$ at $288^{\circ} \mathrm{C}$. Crack growth tests were conducted under cycling loading and long hold time trapezoidal loading in simulated boiling water reactor (BWR) environments, and fracture toughness tests were conducted in air. Neutron irradiation at $288^{\circ} \mathrm{C}$ decreases the fracture toughness of the steels; the data from commercial heats fall within the scatter band for the data obtained at higher temperatures. In addition, the results indicate significant enhancement of CGRs of the irradiated steels in normal water chemistry BWR environment; the CGRs for irradiated steels are a factor of 5 higher than the disposition curve proposed for sensitized austenitic SSs. The rates decreased by more than an order of magnitude in low-dissolved-oxygen BWR environment.
\end{abstract}




\section{Contents}

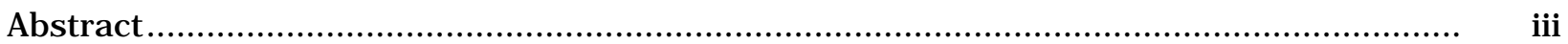

Executive Summary .................................................................................. xiii

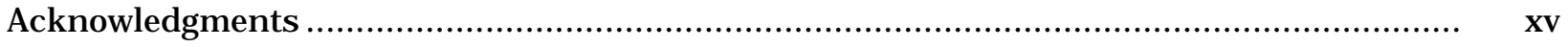

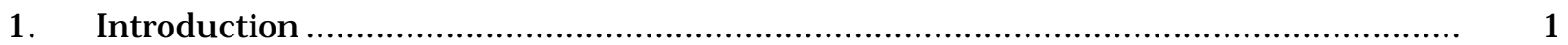

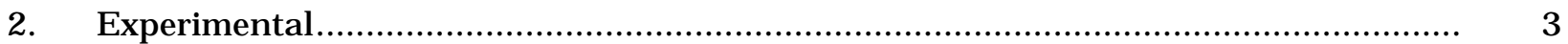

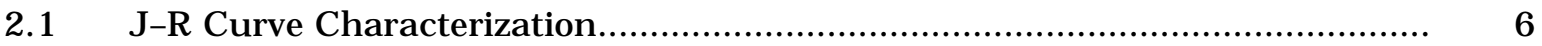

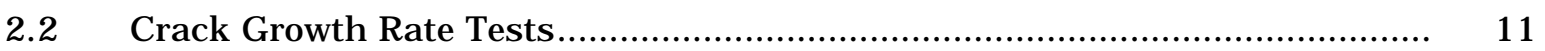

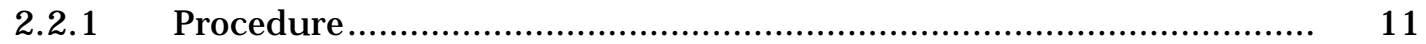

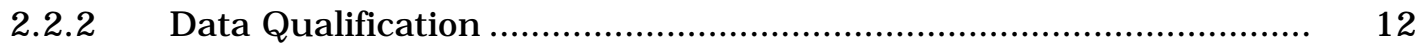

2.2.3 Effect of Specimen Size.................................................. 13

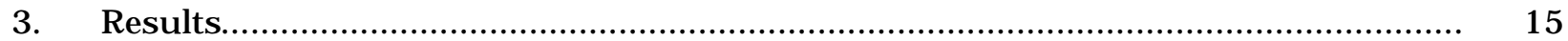

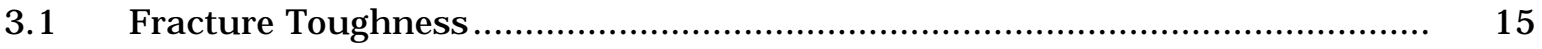

3.1.1 Nonirradiated Type 304 Stainless Steel................................ 15

3.1.2 Irradiated Type 304 Stainless Steels..................................... 18

3.2 Crack Growth Tests on Irradiated Stainless Steels in BWR Environments..... 21

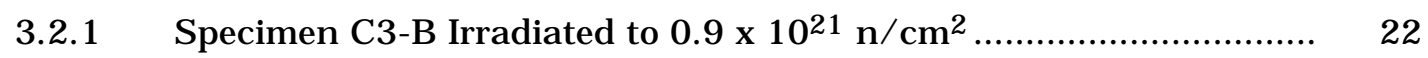

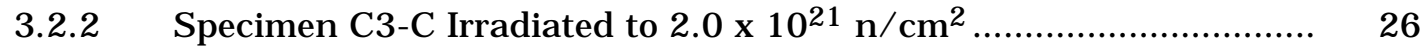

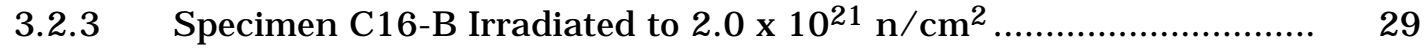

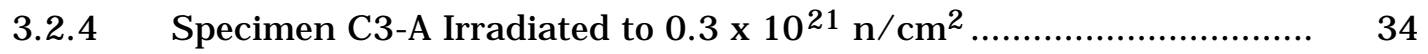

3.2.5 CGRs of Irradiated Austenitic SSs under Continuous Cycling......... 37

3.2.6 CGRs of Irradiated Austenitic SSs under Cycling with Long Hold Periods .................................................................... 38

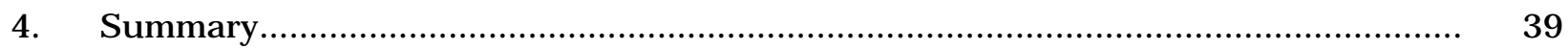

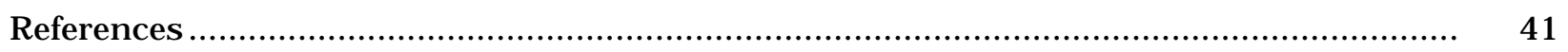

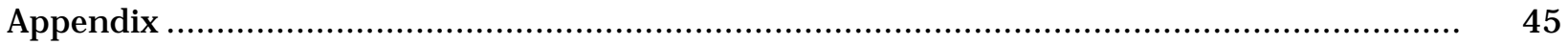




\section{Figures}

1. Fracture toughness $\mathrm{J}_{\mathrm{Ic}}$ as a function of neutron exposure for austenitic Types 304 and 316 SS

2. Configuration of compact-tension specimen used for this study ........................... 3

3. Schematic representation of hot-cell J-R test facility ........................................ 3

4. Schematic of the actuator, load cell, test train, autoclave, and furnace.................. 4

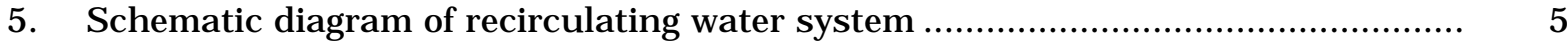

6. Examples of load-vs.-loadline displacement curves for irradiated specimens of Heats C19 and L20 of Type 304 SS tested at $288^{\circ} \mathrm{C}$

7. Fracture toughness J-R curves obtained from DC potential and elastic unloading compliance methods for specimens Y4-02 and Y4-03 of thermally aged cast $\mathrm{CF}-8 \mathrm{M}$ SS

8. Fracture toughness J-R curves obtained from DC potential and elastic unloading compliance methods for thermally aged Heat 75 of cast CF-8M SS; specimen 75-03T, 75-04T, and 75-10T

9. Fracture toughness J-R curves obtained from DC potential and elastic unloading compliance methods for 50\% cold-worked Type $316 \mathrm{NG}$; specimen $184-38$ and $184-40$.

10. Fracture toughness J-R curves for 1/4-T and 1-T CT specimens of aged Heat 75 of $\mathrm{CF}-8 \mathrm{M}$ cast stainless steel at $288^{\circ} \mathrm{C}$

11. Crack growth rate data under continuous cycling for thermally aged cast SS and $50 \%$ cold-worked Type $316 \mathrm{LN}$ SS in high-purity water at $289^{\circ} \mathrm{C}$.

12. Stress corrosion cracking data for austenitic stainless steels in high-DO water at $289^{\circ} \mathrm{C}$

13. Fracture toughness J-R curve obtained by DC potential and unloading compliance methods for nonirradiated specimens L2-C and L2-E of Heat L2 of Type $304 \mathrm{SS}$ at $288^{\circ} \mathrm{C}$.

14. Fracture toughness J-R curve obtained by DC potential and unloading compliance methods for nonirradiated specimen L20-D of Heat L20 of Type $304 \mathrm{SS}$ at $288^{\circ} \mathrm{C}$.

15. Fracture toughness J-R curve obtained by DC potential and unloading compliance methods for nonirradiated specimens C16-C and C16-D of Heat C16 of Type $316 \mathrm{SS}$ at $288^{\circ} \mathrm{C}$.

16. Fracture toughness J-R curve obtained by DC potential and unloading compliance methods for nonirradiated specimen C19-D of Heat C19 of Type $304 \mathrm{SS}$ at $288^{\circ} \mathrm{C}$. 
17. Fracture toughness J-R curves for nonirradiated Type 304 stainless steels at $288^{\circ} \mathrm{C}$

18. Photomicrographs of fracture surfaces of nonirradiated specimens of Heats L2 and $\mathrm{L} 20$ tested at $288^{\circ} \mathrm{C}$.

19. Photomicrograph of fracture surface of nonirradiated specimen of Heat C19 tested at $288^{\circ} \mathrm{C}$

20. Photomicrograph of MnS inclusions on the fracture surface of nonirradiated specimen of Heat $\mathrm{L} 2$ tested at $288^{\circ} \mathrm{C}$.

21. Fracture toughness J-R curve obtained by DC potential and unloading compliance methods at $288^{\circ} \mathrm{C}$ for Heat C19 of Type 304 SS irradiated to a fluence level of $0.3,0.9$, and $2.0 \times 10^{21} \mathrm{n} / \mathrm{cm}^{2}$.

22. Fracture toughness J-R curve obtained by DC potential and unloading compliance methods at $288^{\circ} \mathrm{C}$ for Heat C16 of Type $316 \mathrm{SS}$ irradiated to a fluence level of $0.9 \times 10^{21} \mathrm{n} / \mathrm{cm}^{2}$

23. Fracture toughness J-R curve obtained by DC potential and unloading compliance methods at $288^{\circ} \mathrm{C}$ for Heat L20 of Type 304 SS irradiated to a fluence level of 0.3 and $0.9 \times 10^{21} \mathrm{n} / \mathrm{cm}^{2}$.

24. Fracture toughness J-R curve obtained by DC potential and unloading compliance methods at $288^{\circ} \mathrm{C}$ for Heat L2 of Type 304 SS irradiated to a fluence level of $0.9 \times 10^{21} \mathrm{n} / \mathrm{cm}^{2}$

25. Fracture toughness $\mathrm{J}_{\mathrm{Ic}}$ of austenitic stainless steels as a function of neutron exposure at $288^{\circ} \mathrm{C}$.

26. Changes in crack length and ECP after the dissolved oxygen level in the feedwater was decreased from 500 to $10 \mathrm{ppb}$ and increased from 10 to $300 \mathrm{ppb}$

27. Photomicrographs of the fracture surface of specimen C3-B tested in high-purity water at $289^{\circ} \mathrm{C}$.

28. Crack-length-vs.-time plots for irradiated Type 304 SS in high-purity water at $289^{\circ} \mathrm{C}$ during test periods $2-5,6,7-8,9-12$, and $14-15$...

29. Change in crack length and ECP of Pt and SS electrodes for Specimen C3-C after the dissolved oxygen level in the feedwater was decreased from 300 to $10 \mathrm{ppb}$.....

30. Photomicrographs of the fracture surface of Specimen C3-C

31. Crack-length-vs.-time plots for irradiated Type 304 SS in high-purity water at $289^{\circ} \mathrm{C}$ during test periods $1-2,3-5,6-7$, and $7-8$

32. Change in crack length and ECP of Pt and SS electrodes when the DO level in feedwater was decreased from 300 to $<40 \mathrm{ppb}$ and increased from $<40$ to $300 \mathrm{ppb}$. 
33. Photomicrographs of the fracture surface of Specimen C16-B

34. Crack-length-vs.-time plots for irradiated Type 316 SS in high-purity water at $289^{\circ} \mathrm{C}$ during test periods up to $1,2-3,4-5,6-7,8-10,11-12$, and $13-15$.

35. Photomicrographs of the fracture surface of Specimen C3-A.

36. Crack-length-vs.-time plots for irradiated Type 316 SS in high-purity water at $289^{\circ} \mathrm{C}$ during test periods $1-2,3-5,6-7,8-10$, and $11-12$......

37. CGR data for irradiated austenitic SSs under continuous cycling at $289^{\circ} \mathrm{C}$ in high-purity water with $300 \mathrm{ppb}$ and $<30 \mathrm{ppb}$ dissolved oxygen.

38. CGR data under constant load with periodic partial unloads for irradiated austenitic SSs in high-purity water at $289^{\circ} \mathrm{C}$

A-1.1. Load-vs.-loadline displacement curve for specimen Y4-03 of thermally aged $\mathrm{CF}-8 \mathrm{M}$ cast $\mathrm{SS}$ tested at $288^{\circ} \mathrm{C}$

A-1.2. Fracture surface of specimen Y4-03 tested at $288^{\circ} \mathrm{C}$

A-2.1. Load-vs.-loadline displacement curve for specimen Y4-02 of thermally aged $\mathrm{CF}-8 \mathrm{M}$ cast $\mathrm{SS}$ tested at $288^{\circ} \mathrm{C}$

A-2.2. Fracture surface of specimen Y4-02 tested at $288^{\circ} \mathrm{C}$

A-3.1. Load-vs.-loadline displacement curve for specimen 75-03T of thermally aged $\mathrm{CF}-8 \mathrm{M}$ cast $\mathrm{SS}$ tested at $288^{\circ} \mathrm{C}$

A-3.2. Fracture surface of specimen $75-03 \mathrm{~T}$ tested at $288^{\circ} \mathrm{C}$

A-4.1. Load-vs.-loadline displacement curve for specimen 75-04T of thermally aged $\mathrm{CF}-8 \mathrm{M}$ cast SS tested at $288^{\circ} \mathrm{C}$

A-4.2. Fracture surface of specimen $75-04 \mathrm{~T}$ tested at $288^{\circ} \mathrm{C}$

A-5.1. Load-vs.-loadline displacement curve for specimen 75-10T of thermally aged $\mathrm{CF}-8 \mathrm{M}$ cast $\mathrm{SS}$ tested at $288^{\circ} \mathrm{C}$

A-5.2. Fracture surface of specimen $75-10 \mathrm{~T}$ tested at $288^{\circ} \mathrm{C}$

A-6.1. Load-vs.-loadline displacement curve for specimen 184-38 of 50\% cold-worked Type $316 \mathrm{NG}$ SS tested at $288^{\circ} \mathrm{C}$

A-6.2. Fracture surface of specimen $184-38$ tested at $288^{\circ} \mathrm{C}$

A-7.1. Load-vs.-loadline displacement curve for specimen $184-40$ of 50\% cold-worked Type $316 \mathrm{NG}$ SS tested at $288^{\circ} \mathrm{C}$

A-7.2. Fracture surface of specimen $184-40$ tested at $288^{\circ} \mathrm{C}$

A-8.1. Load-vs.-loadline displacement curve for specimen C19-D of nonirradiated Type $304 \mathrm{SS}$ tested at $288^{\circ} \mathrm{C}$ 
A-8.2. Fracture surface of specimen C19-D tested at $288^{\circ} \mathrm{C}$

A-9.1. Load-vs.-loadline displacement curve for specimen C16-C of nonirradiated Type $316 \mathrm{SS}$ tested at $288^{\circ} \mathrm{C}$

A-9.2. Fracture surface of specimen $\mathrm{C} 16-\mathrm{C}$ tested at $288^{\circ} \mathrm{C}$

A-10.1. Load-vs.-loadline displacement curve for specimen C16-D of nonirradiated Type $316 \mathrm{SS}$ tested at $288^{\circ} \mathrm{C}$

A-10.2. Fracture surface of specimen C16-D tested at $288^{\circ} \mathrm{C}$

A-11.1. Load-vs.-loadline displacement curve for specimen L20-D of nonirradiated Type $304 \mathrm{SS}$ tested at $288^{\circ} \mathrm{C}$

A-11.2. Fracture surface of specimen L20-D tested at $288^{\circ} \mathrm{C}$

A-12.1. Load-vs.-loadline displacement curve for specimen L2-C of nonirradiated Type 304 SS tested at $288^{\circ} \mathrm{C}$

A-12.2. Fracture surface of specimen $\mathrm{L} 2-\mathrm{C}$ tested at $288^{\circ} \mathrm{C}$

A-13.1. Load-vs.-loadline displacement curve for specimen L2-E of nonirradiated Type 304 SS tested at $288^{\circ} \mathrm{C}$

A-13.2. Fracture surface of specimen $\mathrm{L} 2-\mathrm{E}$ tested at $288^{\circ} \mathrm{C}$

A-14.1 Load-vs.-loadline displacement curve for specimen C19-A of irradiated Type 304 SS tested at $288^{\circ} \mathrm{C}$

A-14.2 Fracture surface of specimen C19-A tested at $288^{\circ} \mathrm{C}$

A-15.1 Load-vs.-loadline displacement curve for specimen C19-B of irradiated Type $304 \mathrm{SS}$ tested at $288^{\circ} \mathrm{C}$

A-15.2 Fracture surface of specimen C19-B tested at $288^{\circ} \mathrm{C}$.

A-16.1 Load-vs.-loadline displacement curve for specimen C19-C of irradiated Type 304 SS tested at $288^{\circ} \mathrm{C}$

A-16.2 Fracture surface of specimen C19-C tested at $288^{\circ} \mathrm{C}$

A-17.1 Load-vs.-loadline displacement curve for specimen C16-A of irradiated Type 316 SS tested at $288^{\circ} \mathrm{C}$

A-17.2 Fracture surface of specimen C16-A tested at $288^{\circ} \mathrm{C}$

A-18.1. Load-vs.-loadline displacement curve for specimen L20-A of irradiated Type $304 \mathrm{SS}$ tested at $288^{\circ} \mathrm{C}$

A-18.2. Fracture surface of specimen L2O-A tested at $288^{\circ} \mathrm{C}$

A-19.1. Load-vs.-loadline displacement curve for specimen L20-B of irradiated Type 304 SS tested at $288^{\circ} \mathrm{C}$ 
A-19.2. Fracture surface of specimen L20-B tested at $288^{\circ} \mathrm{C}$

A-20.1. Load-vs.-loadline displacement curve for specimen L2-A of irradiated

Type 304 SS tested at $288^{\circ} \mathrm{C}$

A-20.2. Fracture surface of specimen L2-A tested at $288^{\circ} \mathrm{C}$

86

\section{Tables}

1. Composition of austenitic stainless steels irradiated in the Halden reactor........... 6

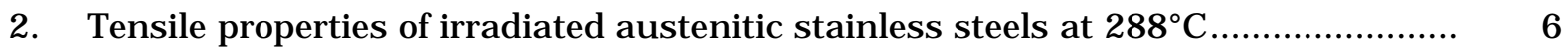

3. Crack growth results for Specimen C3-B of Type 304 SS in high-purity water at $289^{\circ} \mathrm{C}$

4. Crack growth results for Specimen C3-C of Type 304 SS in high-purity water at $289^{\circ} \mathrm{C}$

5. Crack growth results for Specimen C16-B of Type 316 SS in high-purity water at $289^{\circ} \mathrm{C}$

6. Crack growth results for Specimen C3-A of Type 304 SS in high-purity water at $289^{\circ} \mathrm{C}$

A-1. Test data for specimen Y4-03 of thermally aged CF-8M cast SS tested at $288^{\circ} \mathrm{C}$

A-2. Test data for specimen Y4-02 of thermally aged CF-8M cast SS tested at $288^{\circ} \mathrm{C}$

A-3. Test data for specimen 75-03T of thermally aged CF-8M cast SS tested at $288^{\circ} \mathrm{C}$

A-4. Test data for specimen 75-04T of thermally aged CF-8M cast SS tested at $288^{\circ} \mathrm{C}$

A-5. Test data for specimen 75-10T of thermally aged CF-8M cast SS tested at $288^{\circ} \mathrm{C}$

A-6. Test data for specimen 184-38 of 50\% cold-worked Type 316NG SS tested at $288^{\circ} \mathrm{C}$

A-7. Test data for specimen 184-40 of 50\% cold-worked Type 316NG SS tested at $288^{\circ} \mathrm{C}$

A-8. Test data for specimen C19-D of nonirradiated Type 304 SS tested at $288^{\circ} \mathrm{C}$

A-9. Test data for specimen C16-C of nonirradiated Type 316 SS tested at $288^{\circ} \mathrm{C}$ 
A-10. Test data for specimen C16-D of nonirradiated Type 316 SS tested at $288^{\circ} \mathrm{C} \ldots \ldots . . .65$

A-11. Test data for specimen L20-D of nonirradiated Type 304 SS tested at $288^{\circ} \mathrm{C} \ldots \ldots \ldots . \quad 67$

A-12. Test data for specimen L2-C of nonirradiated Type 304 SS tested at $288^{\circ} \mathrm{C} \ldots \ldots \ldots . . \quad 69$

A-13. Test data for specimen L2-E of nonirradiated Type 304 SS tested at $288^{\circ} \mathrm{C} \ldots \ldots \ldots . . \quad 71$

A-14. Test data for specimen C19-A of irradiated Type 304 SS tested at $288^{\circ} \mathrm{C} \ldots \ldots \ldots \ldots \ldots . . . . . \quad 73$

A-15. Test data for specimen C19-B of irradiated Type 304 SS tested at $288^{\circ} \mathrm{C} \ldots \ldots \ldots \ldots \ldots . . . . . \quad 75$

A-16. Test data for specimen C19-C of irradiated Type 304 SS tested at $288^{\circ} \mathrm{C} \ldots \ldots \ldots \ldots . . . . . \quad 77$

A-17. Test data for specimen C16-A of irradiated Type 316 SS tested at $288^{\circ} \mathrm{C} \ldots \ldots \ldots \ldots . . . . . \quad 79$

A-18. Test data for specimen L20-A of irradiated Type 304 SS tested at $288^{\circ} \mathrm{C} \ldots \ldots \ldots \ldots \ldots . \quad 81$

A-19. Test data for specimen L20-B of irradiated Type 304 SS tested at $288^{\circ} \mathrm{C} \ldots \ldots \ldots \ldots \ldots . . . . \quad 83$

A-20. Test data for specimen L2-A of irradiated Type 304 SS tested at $288^{\circ} \mathrm{C} \ldots \ldots \ldots \ldots \ldots . \quad 85$ 


\section{Executive Summary}

Austenitic stainless steels (SSs) are used extensively as structural alloys in the internal components of reactor pressure vessels because of their high strength, ductility, and fracture toughness. Fracture of these steels occurs by stable tearing at stresses well above the yield stress, and tearing instabilities require extensive plastic deformation. However, exposure to neutron irradiation for extended periods changes the microstructure and degrades the fracture properties of these steels. Irradiation leads to a significant increase in yield strength and reduction in ductility and fracture resistance of austenitic SSs. Existing data on fracture toughness of austenitic SSs indicate substantial decrease in toughness at exposures of 1-10 dpa; the effect is largest in high-toughness steels. However, most of the existing fracture toughness test data have been obtained at temperatures above $350^{\circ} \mathrm{C}$; fracture toughness results that are relevant to light water reactors (LWRs) are very limited.

In addition, radiation can exacerbate the corrosion fatigue and stress corrosion cracking (SCC) behavior of SSs by affecting the material microchemistry, e.g., radiation-induced segregation; material microstructure, e.g., radiation hardening; and water chemistry, e.g., radiolysis. Service failures in core components of several operating reactors have been attributed to irradiation assisted stress corrosion cracking (IASCC). While initially considered as a unique form of cracking that would not occur in the absence of radiation, IASCC is now generally considered as a radiation accelerated environmental cracking process. It has been termed as premature subcritical cracking of materials exposed to ionizing irradiation. The factors that influence SCC susceptibility of materials include neutron fluence, cold work, corrosion potential, water purity, temperature, and loading.

This report presents experimental data on fracture toughness and crack growth rate (CGR) for austenitic Types 304 and 316 SS that were irradiated to fluence levels of $0.3,0.9$, and $2.0 \times 10^{21} \mathrm{n} / \mathrm{cm}^{2}(\mathrm{E}>1 \mathrm{MeV})(0.45,1.35$, and $3.0 \mathrm{dpa})$ at $288^{\circ} \mathrm{C}$. The irradiations were carried out in a He environment in the Halden heavy water boiling reactor. Fracture toughness tests were conducted in air and CGR tests in normal water chemistry (NWC) and hydrogen water chemistry (HWC) BWR environments at $288^{\circ} \mathrm{C}$. All tests were performed on $1 / 4-\mathrm{T}$ compact tension specimens.

Neutron irradiation at $288^{\circ} \mathrm{C}$ to $2.0 \times 10^{21} \mathrm{n} / \mathrm{cm}^{2}(\mathrm{E}>1 \mathrm{MeV})(3.0 \mathrm{dpa})$ decreased the fracture toughness of all of the steels. In general, fracture toughness of the commercial Heats $\mathrm{C} 16$ and $\mathrm{C} 19$ is superior to that of the laboratory Heats L2O and L2. These differences arise primarily from differences in toughness of the nonirradiated steels, i.e., the fracture toughness of the laboratory heats is significantly lower than that of the commercial heats. The fracture toughness J-R curves for irradiated Types 304 and 316 SS are comparable. The data from commercial heats fall within the scatter band for the data obtained at higher temperatures. For Heat C19 of Type 304 SS irradiated to $0.3,0.9$, and $2.0 \times 10^{21} \mathrm{n} / \mathrm{cm}^{2}$, the $\mathrm{J}_{\text {Ic }}$ values are 507,313 , and $188 \mathrm{~kJ} / \mathrm{m}^{2}$, respectively.

The results indicate significant enhancement of CGRs of irradiated steel in the NWC BWR environment. The CGRs of irradiated steels are a factor of 5 higher than the disposition curve proposed in NUREG-0313 for sensitized austenitic SSs in water with $8 \mathrm{ppm}$ dissolved oxygen (DO). The CGRs of Type 304 SS irradiated to 0.9 and $2.0 \times 10^{21} \mathrm{n} / \mathrm{cm}^{2}$ and of Types 304 and $316 \mathrm{SS}$ irradiated to $2.0 \times 10^{21} \mathrm{n} / \mathrm{cm}^{2}$ are comparable. 
In low-DO BWR environments, the CGRs of the irradiated steels decreased by an order of magnitude in some tests, e.g., Heat C3 of Type 304 SS irradiated to $0.9 \times 10^{21} \mathrm{n} / \mathrm{cm}^{2}$ and Heat C16 of Type 316 SS irradiated to $2 \times 10^{21} \mathrm{n} / \mathrm{cm}^{2}$. The beneficial effect of decreased DO was not observed for Heat C3 of Type 304 SS irradiated to $2 \times 10^{21} \mathrm{n} / \mathrm{cm}^{2}$; it is possible that this different behavior is associated with the loss of constraint in the specimen due to the high applied load.

Type 304 SS irradiated to $0.3 \times 10^{21} \mathrm{n} / \mathrm{cm}^{2}$ shows very little environmental enhancement of CGRs in the NWC BWR environment; the CGRs under SCC conditions are below the disposition curve for sensitized SSs in water with 8 ppm DO given in NUREG-0313. 


\section{Acknowledgments}

The authors thank T. M. Galvin, L. A. Knoblich, E. J. Listwan, and R. W. Clark for their contributions to the experimental effort. This work is sponsored by the Office of Nuclear Regulatory Research, U.S. Nuclear Regulatory Commission, under Job Code Y6388; Project Manager: W. H. Cullen, Jr. and C. E. Moyer. 


\section{Introduction}

Austenitic stainless steels (SSs) are used extensively as structural alloys in reactor pressure vessel internal components because of their high strength, ductility, and fracture toughness. Fracture of these steels occurs by stable tearing at stresses well above the yield stress, and tearing instabilities require extensive plastic deformation. However, exposure to neutron irradiation for extended periods changes the microstructure and degrades the fracture properties of these steels. Irradiation leads to a significant increase in yield strength and reduction in ductility and fracture resistance of austenitic SSs. ${ }^{1-3}$ Changes in mechanical properties are known to influence fatigue or corrosion fatigue properties of irradiated materials. ${ }^{4}$ Irradiation assisted stress corrosion cracking (IASCC) is another degradation process that affects light water reactor (LWR) internals exposed to fast neutron radiation. 1,5,6

Neutron irradiation of austenitic SSs at temperatures below $400^{\circ} \mathrm{C}$ leads to the formation of a substructure with very fine defects that consist of small $(<5 \mathrm{~nm})$ vacancy and interstitial loops or "black spots" and larger $(>5 \mathrm{~nm})$ faulted interstitial loops. ${ }^{7-9}$ The latter are obstacles to dislocation motion and lead to matrix strengthening and increase in tensile strength. Also, irradiation-induced defects cause loss of ductility and reduced strain-hardening capacity of the material. The effects of radiation on various austenitic SSs vary significantly and appear to be related to minor differences in the chemical composition of the steels; ${ }^{1}$ the chemical composition can influence the stacking fault energy and/or irradiation-induced microstructure. As yield strength approaches ultimate strength, planar slip or dislocation channeling is promoted and leads to pronounced degradation in the fracture resistance of these steels. ${ }^{3}$ In general, higher stacking-fault energy enhances and cold working inhibits dislocation channeling. ${ }^{1}$

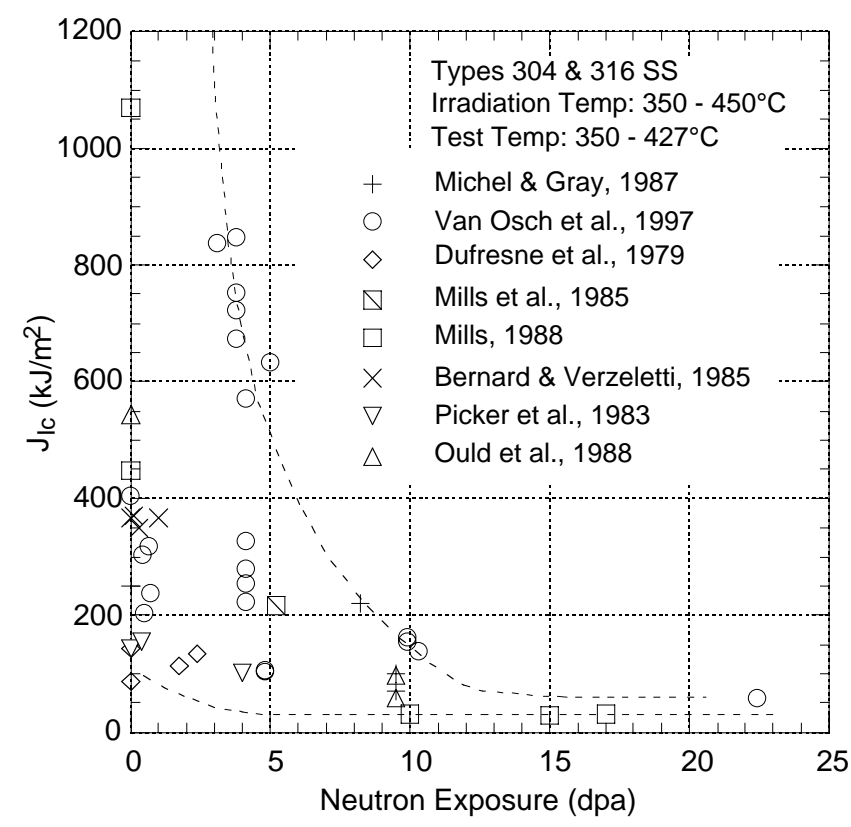

Figure 1.

Fracture toughness $J_{\mathrm{Ic}}$ as a function of neutron exposure for austenitic Types 304 and 316 SS

The effect of neutron exposure on the fracture toughness $\mathrm{J}_{\text {Ic }}$ of austenitic SSs irradiated at $350-450^{\circ} \mathrm{C}$ is shown in Fig. $1 .{ }^{10-18}$ The effects of irradiation may be divided into three regimes: little or no loss of toughness below a threshold exposure of $\approx 1 \mathrm{dpa}$, substantial 
decrease in toughness at exposures of 1-10 dpa, and no further reduction in toughness above a saturation exposure of $10 \mathrm{dpa}$. The effect is largest in high-toughness steels. The degradation in fracture properties saturates at a $J_{\text {Ic }}$ value of $\approx 30 \mathrm{~kJ} / \mathrm{m}^{2}$ (or equivalent critical stress intensity factor $\mathrm{K}_{\mathrm{Jc}}$ of $70 \mathrm{MPa} \mathrm{m}^{0.5}$ ). Also, the failure mode changes from dimple fracture to channel fracture. However, most of the existing fracture toughness test data have been obtained at temperatures above $350^{\circ} \mathrm{C}$; fracture toughness results that are relevant to LWRs are very limited. ${ }^{2}$

Radiation can exacerbate the corrosion fatigue and stress corrosion cracking (SCC) behavior of SSs by affecting the material microchemistry, e.g., radiation-induced segregation; material microstructure, e.g., radiation hardening; and water chemistry, e.g., radiolysis. ${ }^{5}$ Service failures in core components of several boiling water reactors (BWRs) ${ }^{19,20}$ and pressurized water reactors (PWRs) ${ }^{4,21}$ have been attributed to IASCC. While initially considered as a unique form of cracking that would not occur in the absence of radiation, IASCC is now generally considered as a radiation accelerated environmental cracking process. It has been termed as premature subcritical cracking of materials exposed to ionizing irradiation.

The factors that influence SCC susceptibility of materials include neutron fluence, cold work, corrosion potential, water purity, temperature, and loading. The effects of neutron fluence on IASCC of austenitic SSs has been investigated for BWR control blade sheaths ${ }^{20}$ and laboratory tests on BWR-irradiated material; $5,22-24$ the extent of intergranular SCC increases with fluence. Although a threshold fluence level of $5 \times 10^{20} \mathrm{n} / \mathrm{cm}^{2}(\mathrm{E}>1 \mathrm{MeV})$ has been reported for austenitic SSs in BWR environment, the experimental data show an increase in intergranular cracking above a fluence of $\approx 2 \times 10^{20} \mathrm{n} / \mathrm{cm}^{2}(\mathrm{E}>1 \mathrm{MeV})(\approx 0.3 \mathrm{dpa})$. The results also show the beneficial effect of reducing the corrosion potential of the environment. ${ }^{25,26}$ However, low corrosion potential does not provide immunity to IASCC, e.g., intergranular SCC has been observed in cold worked, irradiated SS baffle bolts in PWRs. The threshold fluence for IASCC is higher under low potential conditions such as HWC in BWRs or PWR primary water chemistry.

This report presents experimental data on fracture toughness, corrosion fatigue, and stress corrosion cracking (SCC) of austenitic SSs that were irradiated to fluence levels of $\approx 0.3$, 0.9 , and $2.0 \times 10^{21} \mathrm{n} / \mathrm{cm}^{2}(\mathrm{E}>1 \mathrm{MeV})(\approx 0.45,1.35$, and $3.0 \mathrm{dpa})$ at $\approx 288^{\circ} \mathrm{C}$. The irradiations were carried out in a He environment in the Halden heavy water boiling reactor. Fracture toughness tests were conducted in air and CGR tests in normal water chemistry (NWC) and low-DO BWR environments at $288^{\circ} \mathrm{C}$. The results are compared with the existing data obtained from irradiated reactor internal components removed from operating plants and materials irradiated in test reactors. 


\section{Experimental}

Fracture toughness J-R curve and crack growth rate (CGR) tests have been conducted at $288^{\circ} \mathrm{C}$ on several austenitic SSs that were irradiated up to $2.0 \times 10^{21} \mathrm{n} / \mathrm{cm}^{2}(\mathrm{E}>1 \mathrm{MeV})$ $(\approx 3.0 \mathrm{dpa})$ at $\approx 288^{\circ} \mathrm{C}$ in a helium environment in the Halden boiling heavy water reactor. The tests were performed on 1/4-T compact tension (CT) specimens; the J-R curve tests were performed in air and CGR tests in BWR environments. A modified configuration of the CT specimen geometry, Fig. 2, was used in the present study. Crack extensions were determined by both DC potential and elastic unloading compliance techniques.

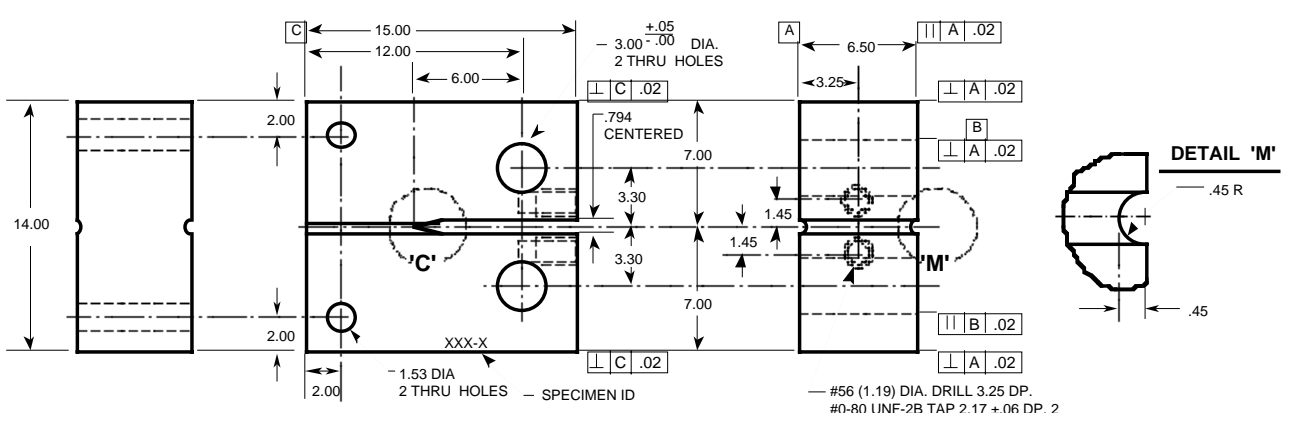

Figure 2. Configuration of compact-tension specimen used for this study (dimensions in $\mathrm{mm}$ )

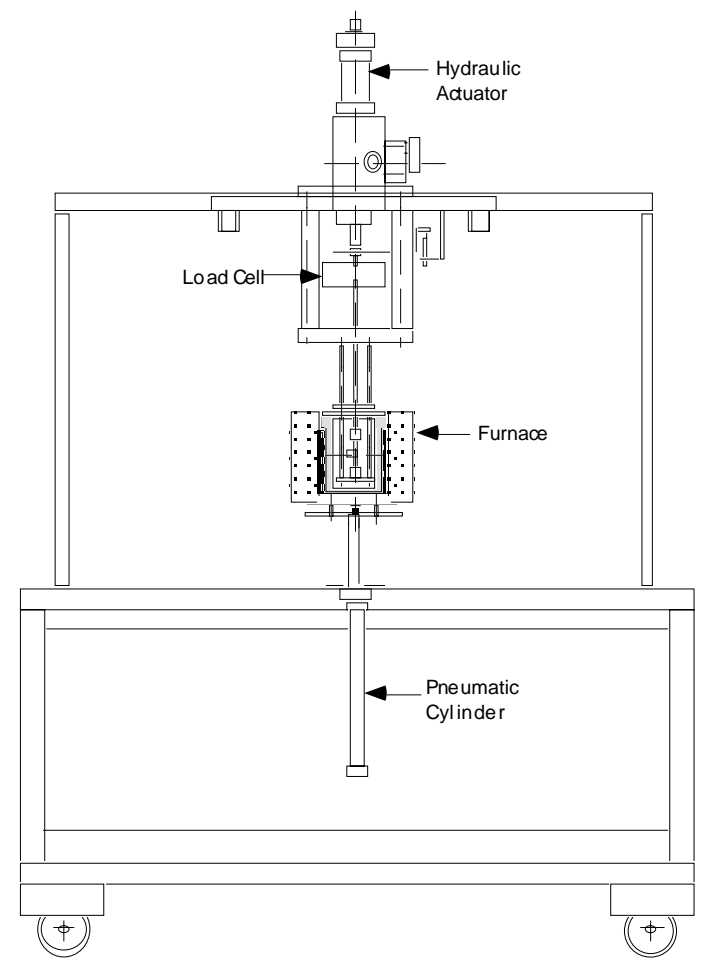

Figure 3. Schematic representation of hot-cell J-R test facility

The facility for conducting the tests is designed for in-cell testing, with the test train, furnace, and other required equipment mounted on top of a portable wheeled cart that can be easily rolled into the cell. A schematic representation of the system is shown in Fig. 3. A small 
autoclave is installed inside the furnace for conducting tests in simulated BWR environments. Water is circulated through a port in the autoclave cover plate that serves both as inlet and outlet. The hydraulic actuator is mounted on top of the frame, with the test train components suspended beneath it. A drawing of the actuator, load cell, test train, autoclave, and furnace are shown in Fig. 4. The 22-kN (5-kip) load cell is at the top of the pull rod. The furnace is mounted on a pneumatic cylinder and can be raised to enclose the autoclave with the load cage and the specimen during the test. An Instron Model 8500+ Dynamic Materials Testing System is used for performing the tests.

The load cage that contains the test specimen consists of the cover plate of a 1-liter SS autoclave (from PARR Associates) and a 12.7-mm-thick bottom plate separated by four compression rods. The lower two-piece clevis assembly is fastened to the bottom plate of the cage with the two sections connected by an oxidized zircalloy pin, electrically insulated with mica washers. The same arrangement is used for the upper clevice assembly, connected to the pull rod. A 1/4-T CT specimen is mounted in the clevises with Inconel pins. Platinum wires are used for the current and potential leads. The current leads are attached to SS split pins that are inserted into the holes at the top and bottom of the specimen. The potential leads are attached by screwing short SS pins into threaded holes in the specimen and attaching the platinum wires with in-line SS crimps.

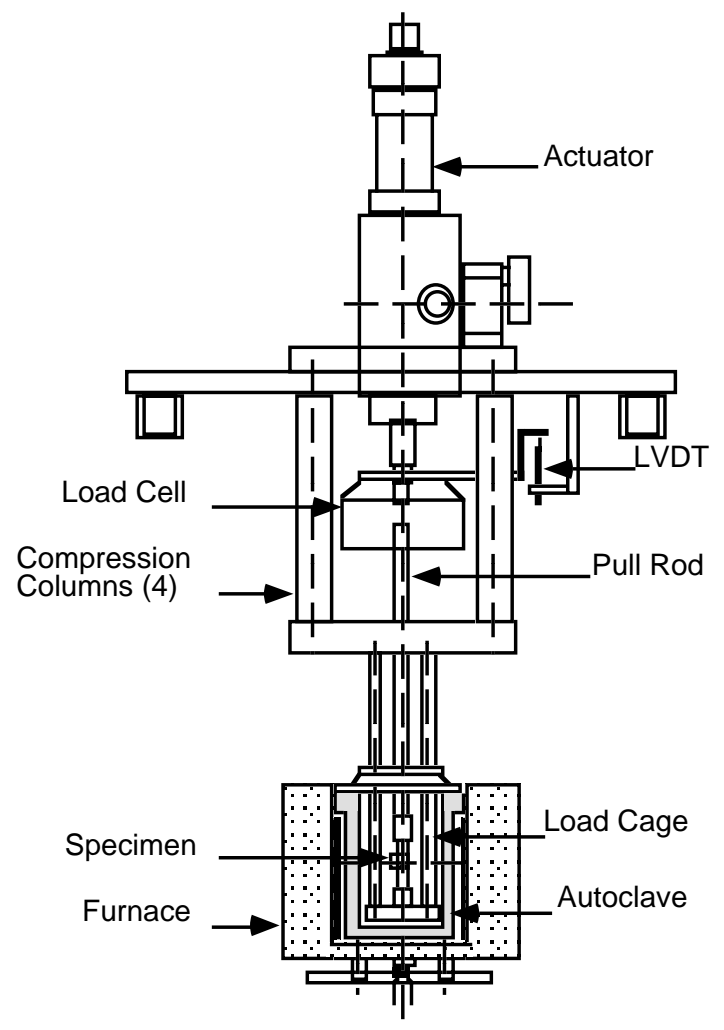

Figure 4. Schematic of the actuator, load cell, test train, autoclave, and furnace

The recirculating water system consists of a storage tank, high pressure pump, regenerative heat exchanger, autoclave preheater, test autoclave, electrochemical potential (ECP) cell preheater, ECP cell, regenerative heat exchanger, Mity Mite ${ }^{\mathrm{TM}}$ back-pressure regulator, an ion-exchange cartridge, a 0.2 micron filter, a demineralizer resin bed, another 
0.2 micron filter, and return line to the tank. A schematic diagram of the recirculating water system is shown in Fig. 5 . Water is circulated at low flow rates, e.g., $\approx 10 \mathrm{~mL} / \mathrm{min}$.

The BWR environments comprise high-purity-deionized water that contains either $\approx 300 \mathrm{ppb}$ or $<30 \mathrm{ppb}$ DO resulting in ECPs for SS that range from 160 to $-500 \mathrm{mV}$. The feedwater is stored in a 135-L SS tank manufactured by Filpaco Industries. The tank is designed for vacuum and over pressure to $60 \mathrm{psig}$. The deionized water is prepared by passing purified water through a set of filters that comprise a carbon filter, an Organex- $\mathrm{Q}$ filter, two ion exchangers, and a $0.2-\mathrm{mm}$ capsule filter. Water samples are taken periodically to measure $\mathrm{pH}$, resistivity, and DO concentration. The DO level in water is established by bubbling nitrogen that contains $\approx 1 \%$ oxygen through the deionized water in the supply tank. The DO is reduced to $<10 \mathrm{ppb}$ by bubbling nitrogen through the water; a vacuum is drawn on the tank cover gas to speed deoxygenation. The cover gas of the storage tank is nitrogen plus $1 \%$ oxygen for high-DO environment, and either pure nitrogen or nitrogen plus 5\% hydrogen for low-DO environment.

1. COVER GAS SUPPLY TANK

2. HIGH-PRESSURE REGULATOR WITH FLASH ARRESTOR

3. LOW-PRESSURE REGULATOR

4. FLOW METER

5. GAS PURIFIER

6. PRESSURE GAUGE

7. PRESSURE RELIEF VALVE

8. VENT TO AIR WITH FLASH ARRESTOR

9. FEEDWATER STORAGE TANK

10. SPARGE TUBE

11. FEEDWATER FILL PORT

12. WATER SAMPLE PORT

13. SOLENOID VALVE

14. $0.2-M I C R O N$ FILTER

15. HIGH-PRESSURE PUMP

16. CHECK VALVE

17. RUPTURE DISK

18. HEAT EXCHANGER

19. SYSTEM BLEED PORT

20. HIGH-PRESSURE GAUGE

21. AUTOCLAVE PREHEATER

22. PARR AUTOCLAVE

23. THERMOCOUPLE WELL

24. ECP CELL PREHEATER

25. ECP CELL

26. ECP CELL BYPASS LINE

27. BACK-PRESSURE RELIEF VAVLE

28. ION EXCHANGE CARTRIDGE

29. RECIRCULATING PUMP

30. DEMINERALIZER

31. DEMINERALIZER BYPASS LINE

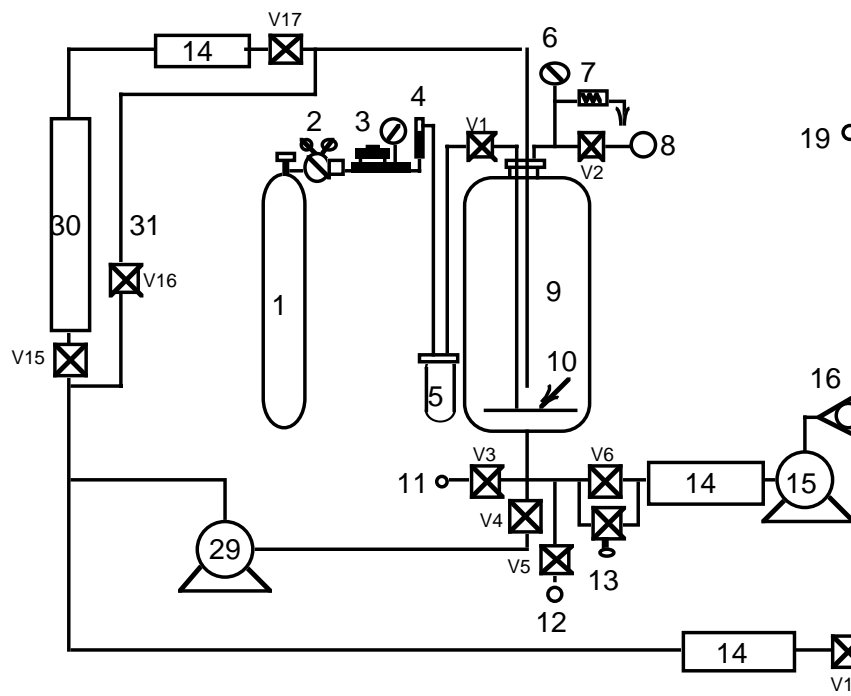

Figure 5. Schematic diagram of recirculating water system

The fracture toughness $\mathrm{J}-\mathrm{R}$ curve tests were performed in accordance with the requirements of ASTM Specification E 1737 for "J-Integral Characterization of Fracture Toughness." The CGR tests were performed in accordance with ASTM E-647 "Standard Test Method for Measurement of Fatigue Crack Growth Rates" and ASTM E-1681 "Standard Test Method for Determining a Threshold Stress Intensity Factor for Environment-Assisted 
Cracking of Metallic Materials Under Constant Load." The composition of the various heats of irradiated austenitic SSs is presented in Table 1. The tensile yield and ultimate stress for the various SSs irradiated to the three fluence levels and in the nonirradiated condition ${ }^{27,28}$ are given in Table 2.

Table 1. Composition (wt.\%) of austenitic stainless steels irradiated in the Halden reactor

\begin{tabular}{ccccccccccccc}
\hline $\begin{array}{c}\text { Alloy } \\
\text { ID }\end{array}$ & $\begin{array}{c}\text { Vendor } \\
\text { Heat ID }\end{array}$ & Analysis & $\mathrm{Ni}$ & $\mathrm{Si}$ & $\mathrm{P}$ & $\mathrm{S}$ & $\mathrm{Mn}$ & $\mathrm{C}$ & $\mathrm{N}$ & $\mathrm{Cr}$ & $\mathrm{Mo}$ & $\mathrm{O}$ \\
\hline \multirow{2}{*}{ C3 } & Type 304 SS & PNL-C-6 & Vendor & 8.91 & 0.46 & 0.019 & 0.004 & 1.81 & 0.016 & 0.083 & 18.55 & \\
& & ANL & 9.10 & 0.45 & 0.020 & 0.003 & 1.86 & 0.024 & 0.074 & 18.93 & 144 \\
C19 & DAN-74827 & Vendor & 8.08 & 0.45 & 0.031 & 0.003 & 0.99 & 0.060 & 0.070 & 18.21 & - \\
& & ANL & 8.13 & 0.51 & 0.028 & 0.008 & 1.00 & 0.060 & 0.068 & 18.05 & 200 \\
L2 & BPC-4-111 & Vendor & 10.50 & 0.82 & 0.080 & 0.034 & 1.58 & 0.074 & 0.102 & 17.02 & 66 \\
L20 & BPC-4-101 & Vendor & 8.91 & 0.17 & 0.010 & 0.004 & 0.41 & 0.002 & 0.002 & 18.10 & - \\
& & ANL & 8.88 & 0.10 & 0.020 & 0.005 & 0.47 & 0.009 & 0.036 & 18.06 & 940 \\
& & & & & & & & & & & \\
C16 & Type 316 SS & PNL-SS-14 & Vendor & 12.90 & 0.38 & 0.014 & 0.002 & 1.66 & 0.020 & 0.011 & 16.92 & - \\
& & ANL & 12.32 & 0.42 & 0.026 & 0.003 & 1.65 & 0.029 & 0.011 & 16.91 & 2.18 & 157 \\
\hline
\end{tabular}

aFirst letters "C" and "L" denote commercial and laboratory heats, respectively.

bIn wppm.

Table 2. Tensile properties ${ }^{\mathrm{a}}$ of irradiated austenitic stainless steels at $288^{\circ} \mathrm{C}$

\begin{tabular}{|c|c|c|c|c|c|c|c|c|}
\hline \multirow[b]{3}{*}{$\begin{array}{c}\text { Steel Type } \\
\text { (Heat) }\end{array}$} & & & \multicolumn{6}{|c|}{ Fluence $(\mathrm{E}>1 \mathrm{MeV})$} \\
\hline & \multicolumn{2}{|c|}{ Nonirradiated } & \multicolumn{2}{|c|}{$0.3 \times 10^{21} \mathrm{n} / \mathrm{cm}^{2}$} & \multicolumn{2}{|c|}{$0.9 \times 10^{21} \mathrm{n} / \mathrm{cm}^{2}$} & \multicolumn{2}{|c|}{$2.0 \times 10^{21} \mathrm{n} / \mathrm{cm}^{2}$} \\
\hline & $\begin{array}{l}\text { Yield } \\
(\mathrm{MPa})\end{array}$ & $\begin{array}{l}\text { Ultimate } \\
(\mathrm{MPa})\end{array}$ & $\begin{array}{l}\text { Yield } \\
\text { (MPa) }\end{array}$ & $\begin{array}{l}\text { Ultimate } \\
(\mathrm{MPa})\end{array}$ & $\begin{array}{l}\text { Yield } \\
(\mathrm{MPa})\end{array}$ & $\begin{array}{l}\text { Ultimate } \\
(\mathrm{MPa})\end{array}$ & $\begin{array}{l}\text { Yield } \\
(\mathrm{MPa})\end{array}$ & $\begin{array}{c}\text { Ultimate } \\
(\mathrm{MPa})\end{array}$ \\
\hline 304 SS (C3) & $(154)$ & $(433)$ & 338 & 491 & 632 & 668 & 796 & 826 \\
\hline 304 SS (C19) & 178 & 501 & 554 & 682 & 750 & 769 & 787 & 801 \\
\hline 304 SS (L2) & 193 & 348 & - & - & 839 & 849 & - & - \\
\hline 304 SS (L20) & - & - & 454 & 552 & $\begin{array}{l}670 \\
632\end{array}$ & $\begin{array}{l}743 \\
697\end{array}$ & - & - \\
\hline 316 SS (C16) & (189) & $(483)$ & 370 & 527 & 562 & 618 & 766 & 803 \\
\hline
\end{tabular}

aEstimated values within parentheses.

The experimental data for the fracture toughness $\mathrm{J}-\mathrm{R}$ curves are compiled in the Appendix. Some of the results have been presented earlier. ${ }^{29-32}$ Because tensile properties of the material were not available for some irradiation conditions, estimated values of flow stress were used in the earlier presentations. In the present report, the fracture toughness results have been reevaluated using tensile properties determined from comparably irradiated tensile specimens. ${ }^{27,28}$

Also, in earlier publications, ${ }^{29-33}$ Heat C16 was erroneously identified as Type 304 SS. Because the flow stress for solution annealed Type 316 SS is typically higher than that for solution annealed Type 304 SS, the experimental data for nonirradiated Heat C16 have been corrected in the present report; the difference is essentially in the slope of the blunting line.

\subsection{J-R Curve Characterization}

Before testing, the specimens were fatigue-precracked in air at room temperature. The precracked specimens were then tested at $288^{\circ} \mathrm{C}$ at a constant extension rate; tests were interrupted periodically to determine the crack length. Specimens were held at constant extension to measure crack length by both the DC potential drop and elastic unloading compliance techniques. For most steels, load relaxation occurs during the hold period or 
unloading, which causes a time-dependent nonlinearity in the unloading curve. Consequently, before unloading, the specimen was held for $\approx 1 \mathrm{~min}$ to allow load relaxation. Elastic unloading and reloading was carried out in the load control mode.

Specimen extension was monitored and controlled outside the high-temperature zone. The displacement of load points was determined by subtracting the extension of the load train from the measured extension. The load train displacement was determined as a function of applied load using a very stiff specimen. The load-line displacements determined by this method were compared with actual displacements measured optically during J-R curve tests at room temperature. The measured and estimated values were in very good agreement; for load-line displacements up to $2 \mathrm{~mm}$, the error in the estimated values was $<0.02 \mathrm{~mm}$. ${ }^{33}$ Examples of load-vs.-loadline displacement curves for irradiated SS are shown in Fig. 6.

The J-integral was calculated from the load-vs.-loadline displacement curves according to the correlations for DC(T) specimens in ASTM Specification E 1737. The following correlation, obtained from the best-fit of the experimental data, was used to determine crack lengths by the unloading compliance method.

$$
\mathrm{a}_{\mathrm{i}} / \mathrm{W}=1.2011-7.1572 \mathrm{u}_{\mathrm{x}}+16.87 \mathrm{u}_{\mathrm{x}}^{2}-13.527 \mathrm{u}_{\mathrm{x}}^{3},
$$

where

$$
\begin{aligned}
& \mathrm{u}_{\mathrm{x}}=1 /\left[\left(\mathrm{B}_{\mathrm{ef}} \mathrm{E}_{\mathrm{ef}} \mathrm{C}_{\mathrm{ci}}\right)^{1 / 2}+1\right], \\
& \mathrm{B}_{\mathrm{ef}}=\mathrm{B}-\left(\mathrm{B}-\mathrm{B}_{\mathrm{N}}\right)^{2} / \mathrm{B}, \\
& \mathrm{E}_{\mathrm{ef}}=\mathrm{E} /\left(1-v^{2}\right),
\end{aligned}
$$

$\mathrm{W}$ is the specimen width, $\mathrm{B}$ is the specimen thickness, $\mathrm{B}_{\mathrm{N}}$ is the net specimen thickness or distance between the roots of the side grooves, $\mathrm{E}$ is the elastic modulus, $v$ is Poisson's ratio, and $\mathrm{C}_{\mathrm{ci}}$ is the specimen elastic compliance corrected for rotation of the crack centerline. The effective elastic modulus $\mathrm{E}_{\mathrm{ef}}$ was adjusted with the measured initial crack length $\mathrm{a}_{\mathrm{i}}$, i.e., $\mathrm{E}_{\mathrm{ef}}$ was determined from Eqs. 1 and 2 by using the measured fatigue precrack length $a_{i}$ and the corresponding corrected specimen elastic compliance $\mathrm{C}_{\mathrm{ci}}$.

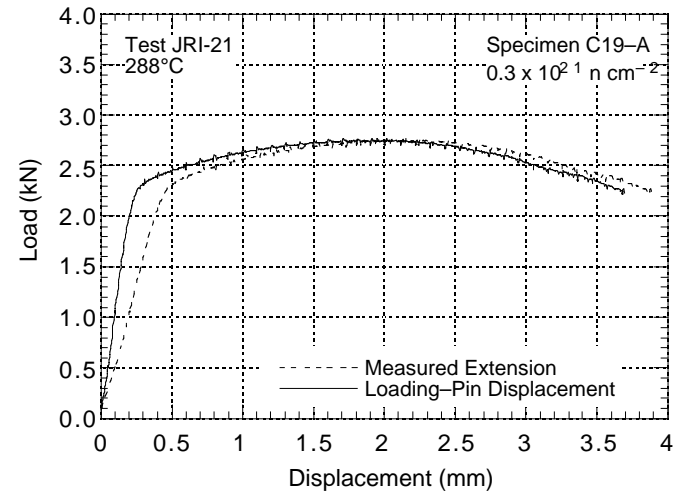

(a)

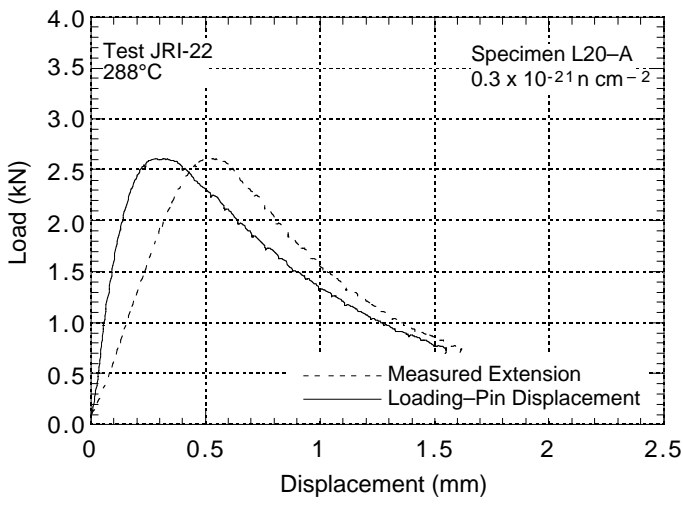

(b)

Figure 6. Examples of load-vs.-loadline displacement curves for irradiated specimens of Heats (a) C19 and (b) L20 of Type 304 SS tested at $288^{\circ} \mathrm{C}$ 
The following correlation, obtained from the best-fit of the experimental data for normalized crack length and normalized DC potential, was used to determine crack lengths by the DC potential method.

$$
\frac{a_{i}}{W}=\left[0.28887\left(\frac{U}{U_{0}}-0.5\right)\right]^{0.34775},
$$

where $\mathrm{W}$ is the specimen width, and $\mathrm{U}$ and $\mathrm{U}_{0}$ are the current and initial potentials. Equation 5 is comparable to the ASTM E 1737 correlation for a CT specimen with current inputs at the $\mathrm{W} / 4$ position and DC potential lead connections at the $\mathrm{W} / 3$ position.

The DC potential data were corrected for the effects of plasticity on the measured potential, i.e., large crack-tip plasticity can increase measured potentials due to resistivity increases without crack extension. As per ASTM E 1737, the change in potential before crack initiation was ignored, and the remainder of the potential change was used to establish the J-R curve. A plot of normalized potential vs. loadline displacement generally remains linear until the onset of crack extension. For all data within the linear portion of the curve, crack extension was calculated from the blunting-line relationship $\Delta \mathrm{a}=\mathrm{J} /\left(4 \sigma_{\mathrm{f}}\right)$, where $\sigma_{\mathrm{f}}$ is the flow stress defined as the average of the $0.2 \%$ offset yield stress and ultimate tensile stress. The exclusion lines are parallel to the blunting line intersecting the abscissa at 0.15 and $1.50 \mathrm{~mm}$.

Although ASTM E 813 specifies a slope of two times the effective yield stress (or flow stress) for the offset line, a slope of four times the flow stress was used to define the offset and exclusion lines. For high-strain-hardening materials, e.g., nonirradiated austenitic SSs, a slope that is four times the flow stress $\left(4 \sigma_{f}\right)$ represents the blunting line better than the slope of $2 \sigma_{\mathrm{f}}$ defined in ASTM E $1737 .{ }^{3}$ In irradiated materials, the increase in yield stress is primarily due to a high density of barriers to dislocation motion. During deformation as dislocations sweep through the irradiated matrix, they annihilate the very fine scale of barriers, thus creating a "channel" for easy dislocation motion. This may result in marked work softening. To account for possible strain softening that may occur in irradiated materials, an effective flow stress defined as the average of the nonirradiated and irradiated flow stress was used in J-R curve data analysis. Because the effective flow stress discounts the irradiation-induced increase in flow stress by a factor of 2 , the slope of the blunting line was defined as $4 \sigma_{\mathrm{f}}$ even for the irradiated materials.

The final crack size was marked by fatigue cycling at room temperature. The specimens were then fractured and the initial (i.e., fatigue precrack) and final (test) crack lengths of both halves of the fractured specimen were measured optically. The crack lengths were determined by the $9 / 8$ averaging technique, i.e., the two near-surface measurements were averaged and the resultant value was averaged with the remaining seven measurements.

The elastic unloading compliance measurements were adjusted only with the measured initial crack length, whereas the crack length measurements obtained by the DC potential-drop technique were adjusted with both the initial and final crack lengths. The two-point pinning method was used to correct the measured potentials from the test data. The corrected normalized potentials $\overline{N P}$ are expressed in terms of the measured normalized potentials $N P$ $\left(\mathrm{U} / \mathrm{U}_{0}\right.$ in Eq. 5) by the relationship 


$$
\overline{N P}=\frac{N P-P_{1}}{P_{2}-P_{1}}
$$

The variables $\mathrm{P}_{1}$ and $\mathrm{P}_{2}$ are solutions of the expressions

$$
\overline{N P}_{i}=\frac{N P_{i}-P_{i}}{P_{2}-P_{1}},
$$

and

$$
\overline{N P}_{f}=\frac{N P_{f}-P_{i}}{P_{2}-P_{1}},
$$

where $\overline{N P}_{i}$ and $\overline{N P}_{f}$ are normalized potentials that correspond to initial and final crack lengths determined from Eq. 5, and $N P_{i}$ and $N P_{f}$ are the measured values. The fracture toughness $\mathrm{J}_{\text {Ic }}$ values were determined from ASTM E-813 as the intersection of the $0.2-\mathrm{mm}$ offset line with the power law fit (of the form $\mathrm{J}=\Delta \mathrm{a}^{\mathrm{n}}$ ) of the test data between the 0.15- and 1.50-mm exclusion lines.

Several fracture toughness $\mathrm{J}-\mathrm{R}$ curve tests were conducted at room temperature and $288^{\circ} \mathrm{C}$ on thermally aged $\mathrm{CF}-8 \mathrm{M}$ cast SS and on a 50\% cold-worked (CW) Type 316LN SS to develop correlations for estimating crack lengths and to validate the test procedure. Experimental data for the tests at $288^{\circ} \mathrm{C}$ are given in the Appendix, Tables A-1 to A-7.

For materials with relatively low fracture toughness, e.g., $J_{\text {Ic }}<300 \mathrm{~kJ} / \mathrm{m}^{2}$, the measurements of crack extension by the elastic unloading compliance method showed excellent agreement with those obtained by DC potential methods. The J-R curves obtained from DC potential and elastic unloading compliance methods for thermally aged cast CF-8M SSs and 50\% cold-worked Type 316NG SS at $288^{\circ} \mathrm{C}$ are shown in Figs. $7-9$. Replicate tests on different specimens of the same material show good reproducibility of the J-R curves.

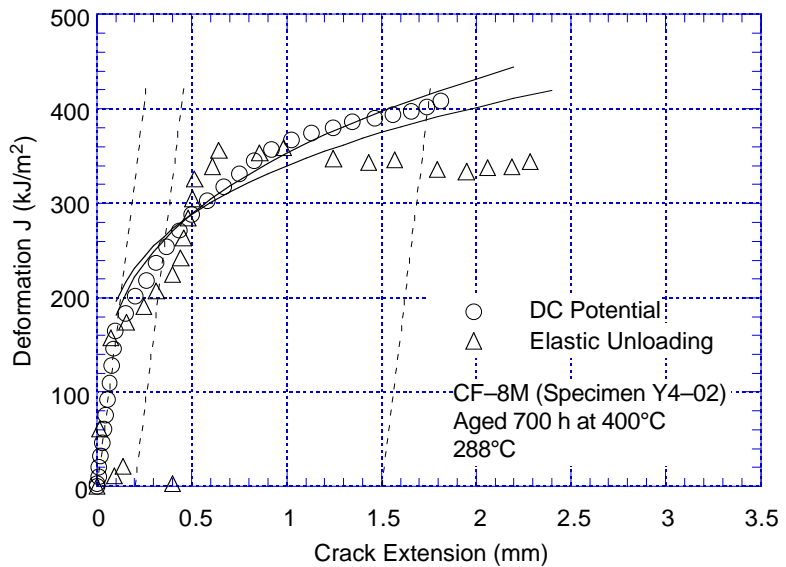

(a)

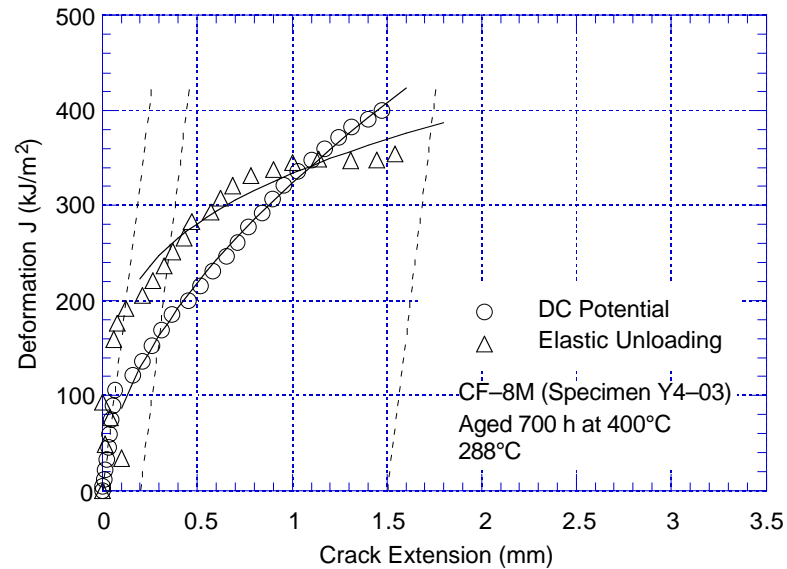

(b)

Figure 7. Fracture toughness $\mathrm{J}-\mathrm{R}$ curves obtained from $\mathrm{DC}$ potential and elastic unloading compliance methods for specimens (a) Y4-02 and (b) Y4-03 of thermally aged cast CF-8M SS 


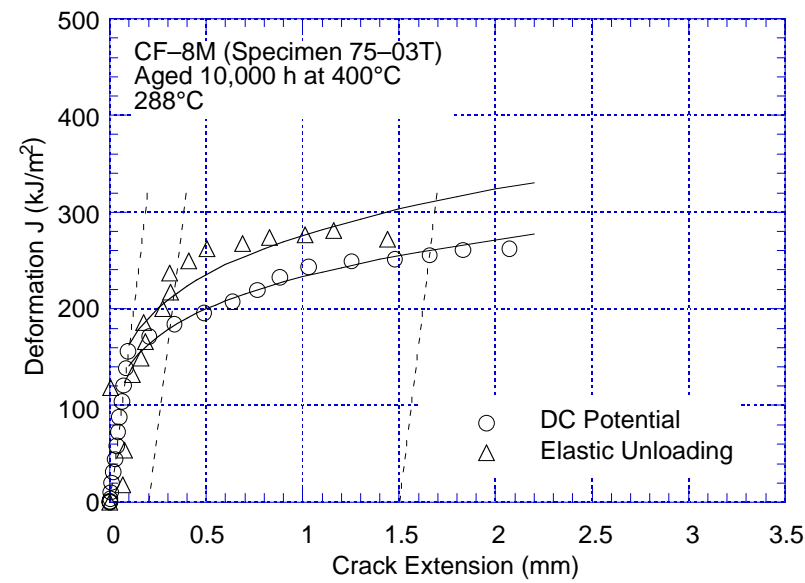

(a)

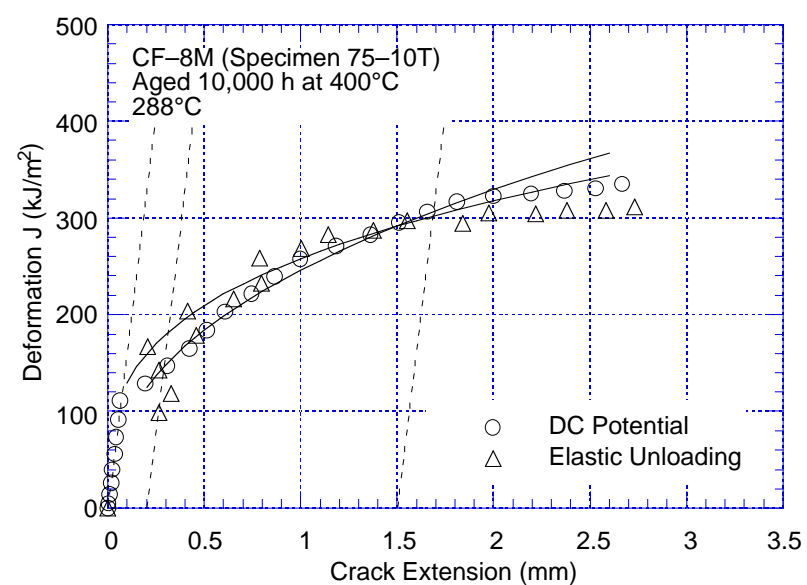

(c)

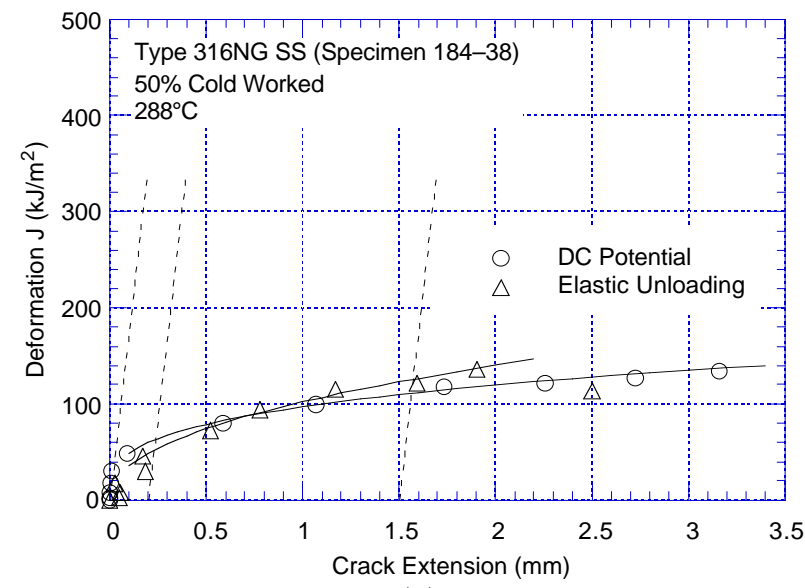

(a)

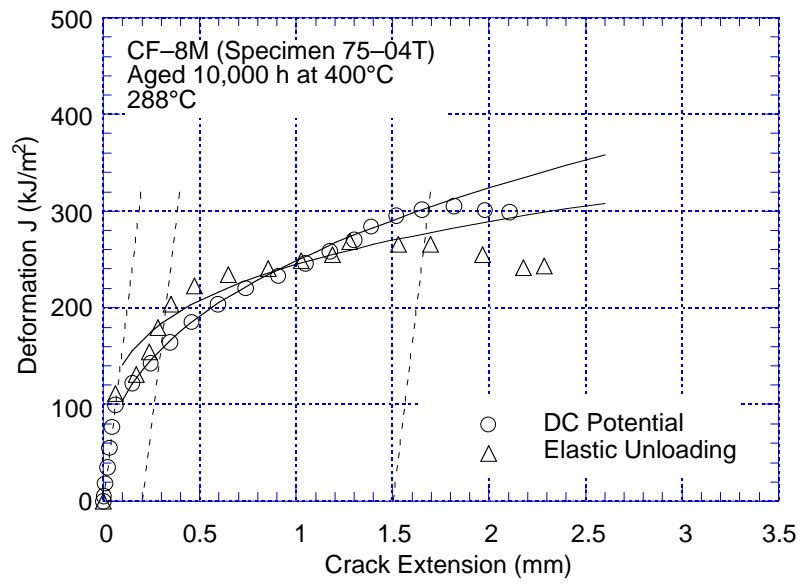

(b)

Figure 8.

Fracture toughness $\mathrm{J}-\mathrm{R}$ curves obtained from DC potential and elastic unloading compliance methods for thermally aged Heat 75 of cast CF-8M SS; specimen (a) 75-03T, (b) 75-04T, and (c) 75-10T

Figure 9. Fracture toughness $\mathrm{J}-\mathrm{R}$ curves obtained from DC potential and elastic unloading compliance methods for 50\% cold-worked Type 316NG; specimen (a) 184-38 and (b) 184-40

The J-R curves obtained from 1/4-T CT specimens of thermally aged Heat 75 of CF-8M cast SS are compared with those obtained from 1-T CT specimens of the same heat in Fig. 10. The curves for the 1/4-T CT specimens show good agreement with the curve for the 1-T CT specimen with the same orientation, e.g., transverse orientation. 


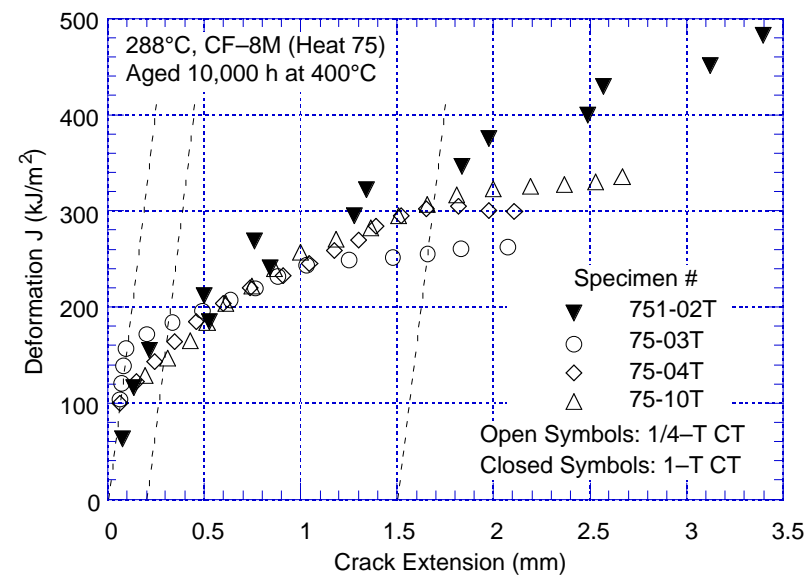

\subsection{Crack Growth Rate Tests}

\subsubsection{Procedure}

All specimens were fatigue precracked in the test environment at temperature and load ratio $\mathrm{R}=0.2, \approx 1 \mathrm{~Hz}$ frequency, and maximum stress intensity factor $\mathrm{K}_{\max } \approx 15 \mathrm{MPa} \mathrm{m}^{1 / 2}$. After $\approx 0.5-\mathrm{mm}$ extension, $\mathrm{R}$ was increased incrementally to 0.7 , and the loading waveform changed to a slow/fast sawtooth with rise times of 30-1000 s. Constant-load tests were conducted with the trapezoidal waveform, $\mathrm{R}=0.7,1-$ or $2-\mathrm{h}$ hold period at peak, and either $4-$ or 24-s unload/reload period. During individual test periods, $\mathrm{K}_{\max }$ was maintained approximately constant by periodic load shedding (less than $2 \%$ decrease in load at any given time).

The stress intensity factor range $\Delta \mathrm{K}$ was calculated as follows:

$$
\begin{aligned}
& \Delta K=\frac{\Delta P}{\left(B B_{N} W\right)^{1 / 2}} \frac{\left(2+\frac{a}{W}\right)}{\left(1-\frac{a}{W}\right)^{3 / 2}} f\left(\frac{a}{W}\right) \\
& \Delta P=P_{\max }-P_{\min } \quad \text { for } \mathrm{R}>0 \\
& f\left(\frac{a}{W}\right)=0.886+4.64\left(\frac{a}{W}\right)-13.32\left(\frac{a}{W}\right)^{2}+14.72\left(\frac{a}{W}\right)^{3}-5.6\left(\frac{a}{W}\right)^{4} .
\end{aligned}
$$

where $P_{\max }$ and $P_{\min }$ are maximum and minimum applied load, a is crack length, $\mathrm{W}$ is the specimen width, and effective thickness $B_{\text {eff }}=\left(B_{N}\right)^{0.5}$. Also, because a modified configuration of disc-shaped CT specimen was used in the present study, crack length was calculated from Eq. 5 that was developed from the best fit of the experimental data for normalized crack length and normalized DC potential.

Under cyclic loading, the CGR $(\mathrm{m} / \mathrm{s})$ can be expressed as the superposition of the rate in air (i.e., mechanical fatigue) and the rates due to corrosion fatigue and SCC, given as

$$
\dot{a}_{e n v}=\dot{a}_{a i r}+\dot{a}_{c f}+\dot{a}_{s c c} \text {. }
$$


During crack growth tests in high-temperature water, environmental enhancement of CGRs does not occur from the start of the test. Under more rapid cyclic loading, the crack growth is dominated by mechanical fatigue. The CGRs during precracking and initial periods of cyclic loading were primarily due to mechanical fatigue. For the present tests on irradiated SSs, environmental enhancement typically was observed under loading conditions that would lead to CGRs between $10^{-10}$ and $10^{-9} \mathrm{~m} / \mathrm{s}$ in air. For $\mathrm{K}_{\max }$ values of $15-18 \mathrm{MPa} \mathrm{m}^{1 / 2}$, these values correspond to a load ratio $\mathrm{R} \geq 0.5$ and rise time $\geq 30 \mathrm{~s}$.

All tests were started in high-purity water that contained 250-300 ppb DO (i.e., NWC BWR environment). The ECPs of a Pt electrode and a SS sample located at the exit of the autoclave were monitored continuously during the test while the water DO level and conductivity were determined periodically. After data were obtained for high-DO water, the DO level in the feedwater was decreased to $<30 \mathrm{ppb}$ by sparging the feedwater with pure $\mathrm{N}_{2}$, and in some cases, this was followed by sparging with $\mathrm{N}_{2}+5 \% \mathrm{H}_{2}$ [to simulate hydrogen water chemistry (HWC) BWR environment]. Because of the very low water flow rates, it took several days for the environmental conditions to stabilize. In general, the changes in ECP of the SS sample were slower than in the ECP of the Pt electrode.

After the test the final crack size was marked by fatigue cycling in air at room temperature. The specimens were then fractured, and the fracture surface of both halves of the specimen was photographed with a telephoto lens through the hot cell window. The final crack length of each half of the fractured specimen was measured from the photograph by the 9/8 averaging technique.

\subsubsection{Data Qualification}

The ASTM specifications for specimen K/size criteria are intended to ensure applicability and transferability of the cracking behavior of a component or specimen of a given thickness under a specific loading condition to a crack associated with a different geometry, thickness, and loading condition.

The CGR test results were validated in accordance with the specimen size criteria of ASTM E 1681 and E 647. These criteria require that the plastic zone at the tip of a fatigue crack is small relative to the specimen geometry. For constant load tests, ASTM E 1681 requires that

$$
\mathrm{B}_{\text {eff }} \text { and }(\mathrm{W}-\mathrm{a}) \geq 2.5\left(\mathrm{~K} / \sigma_{\mathrm{ys}}\right)^{2} \text {, }
$$

and for cyclic loading ASTM 647 requires that

$$
(\mathrm{W}-\mathrm{a}) \geq(4 / \pi)\left(\mathrm{K} / \sigma_{\mathrm{ys}}\right)^{2},
$$

where $\mathrm{K}$ is the applied stress intensity factor, and $\sigma_{\mathrm{ys}}$ is the yield stress of the material. For tests on irradiated material, side grooved specimens are strongly recommended, with a depth for each side groove between 5 and $10 \%$ of the specimen thickness. The effective thickness $B_{\text {eff }}$ of side-grooved specimen should be calculated as a root mean square, i.e., $\left(\mathrm{B} \cdot \mathrm{B}_{\mathrm{N}}\right)^{0.5}$. In high-temperature water, because the primary mechanism for crack growth during continuous cycling is not mechanical fatigue, Eq. 13 is probably the more appropriate criterion, but Eq. 14 may give acceptable results. For high-strain hardening materials, i.e., materials with an 

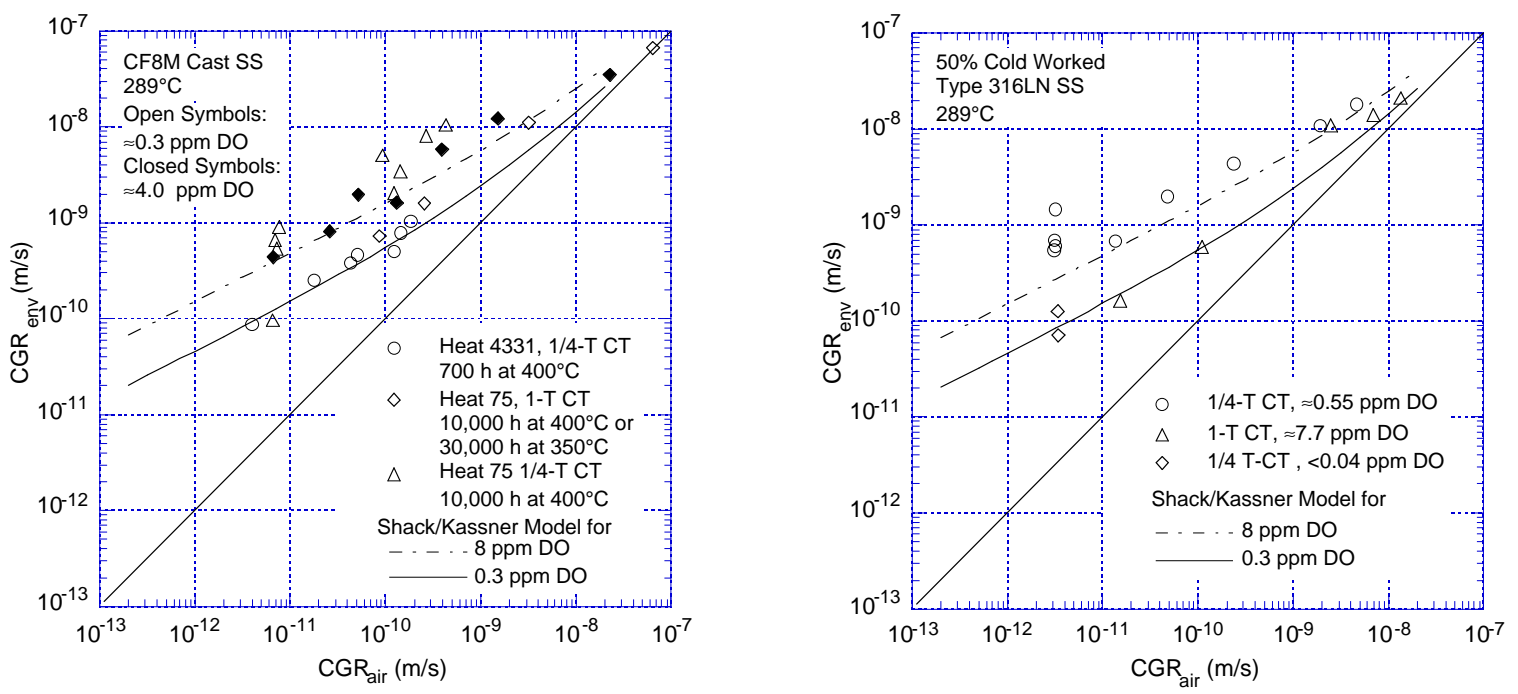

Figure 11. Crack growth rate data under continuous cycling for thermally aged cast SS and $50 \%$ cold-worked Type $316 \mathrm{LN}$ SS in high-purity water at $289^{\circ} \mathrm{C}$.

ultimate to yield stress ratio $\left(\sigma_{\text {ult }} / \sigma_{\mathrm{ys}}\right) \geq 1.3$, both criteria allow the use of the flow stress defined as $\sigma_{\mathrm{f}}=\left(\sigma_{\mathrm{ult}}+\sigma_{\mathrm{ys}}\right) / 2$ rather than the yield stress.

The K/size criteria were developed for materials that show work hardening and, therefore, may not be valid for materials irradiated to fluence levels where, on a local level, they do not strain harden. This lack of strain hardening, or strain softening, is most dramatic when dislocation channeling occurs but may also occur at lower fluences. For moderate to highly irradiated material, it has been suggested that an effective yield stress, defined as the average of the nonirradiated and irradiated yield stresses, be used; ${ }^{34}$ this discounts the irradiation-induced increase in yield stress by a factor of 2 . This modification of the K/size criteria has been used in the current analysis.

\subsubsection{Effect of Specimen Size}

Several CGR tests were conducted on thermally aged CF-8M cast SS and on a 50\% CW Type 316LN SS in BWR environments to establish the test procedures and determine the possible effect of specimen size. The experimental CGRs for the materials in water and those predicted in air for the same loading conditions are plotted in Fig. 11. The results obtained earlier on a 1-T CT specimen of the same heat of 50\% CW Type 316LN SS and Heat 75 of CF8M cast SS in high-DO water are also included in the figure. ${ }^{35}$ The CGRs in air, $\dot{a}_{\text {air }}(\mathrm{m} / \mathrm{s})$, were determined from the correlations developed by James and Jones; ${ }^{36}$ it is expressed as

$$
\dot{a}_{\text {air }}=\mathrm{C}_{\mathrm{SS}} \mathrm{S}(\mathrm{R}) \Delta \mathrm{K}^{3.3} / \mathrm{T}_{\mathrm{R}} \text {, }
$$

where $R$ is the load ratio $\left(\mathrm{K}_{\min } / \mathrm{K}_{\max }\right), \Delta \mathrm{K}$ is $\mathrm{K}_{\max }-\mathrm{K}_{\min }$ in $\mathrm{MPa} \mathrm{m}^{1 / 2}$, $\mathrm{T}_{\mathrm{R}}$ is the rise time (s) of the loading waveform, and function $\mathrm{S}(\mathrm{R})$ is expressed in terms of the load ratio $\mathrm{R}$ as follows:

$$
\begin{array}{ll}
\mathrm{S}(\mathrm{R})=1.0 & \mathrm{R}<0 \\
\mathrm{~S}(\mathrm{R})=1.0+1.8 \mathrm{R} & 0<\mathrm{R}<0.79 \\
\mathrm{~S}(\mathrm{R})=-43.35+57.97 \mathrm{R} & 0.79<\mathrm{R}<1.0,
\end{array}
$$


and function $\mathrm{C}_{\mathrm{SS}}$ is given by a third-order polynomial of temperature $\mathrm{T}\left({ }^{\circ} \mathrm{C}\right)$, expressed as

$$
\mathrm{C}_{\mathrm{SS}}=1.9142 \times 10^{-12}+6.7911 \times 10^{-15} \mathrm{~T}-1.6638 \times 10^{-17} \mathrm{~T}^{2}+3.9616 \times 10^{-20} \mathrm{~T}^{3} .
$$

The two curves in the figure represent the best-fit curves for sensitized austenitic SSs in high-purity water at $289^{\circ} \mathrm{C} .{ }^{35}$ The CGRs in water with $\approx 0.3 \mathrm{ppm}$ DO are given by the expression

$$
\dot{a}_{\text {env }}=\dot{a}_{\text {air }}+4.5 \times 10^{-5}\left(\dot{a}_{\text {air }}\right)^{0.5}
$$

and in water with $\approx 8 \mathrm{ppm}$ DO by the expression

$$
\dot{a}_{e n v}=\dot{a}_{\text {air }}+1.5 \times 10^{-4}\left(\dot{a}_{\text {air }}\right)^{0.5} .
$$

The experimental CGRs for the 1/4-T CT specimen of Heat 4331 are in good agreement with the data obtained on the 1-T CT specimen of Heat 75. The rates for the 1/4-T CT specimen of Heat 75 and 50\% CW Type 316LN SS are somewhat higher. However, the K/size criteria were generally exceeded for these tests, i.e., the values of $K_{\max }$ were higher than those allowed by Eqs. 13 or 14 .

For the 50\% CW Type 316LN SS, the CGR under constant load conditions in high-DO water at $289^{\circ} \mathrm{C}$ is plotted in Fig. 12 ; the maximum stress intensity for the test was within the $\mathrm{K} /$ size-validity criteria. Data obtained earlier on 1-T CT specimens of several heats of Types 304 and 316 SS are also included in the figure. In $\approx 250-$ ppb-DO water, the CGRs for a 1/4-T CT specimen of 50\% CW Type 316LN SS are higher than those for a 1-T CT specimen of sensitized Type 304 SS. Rates for the 1/4-T specimen are comparable to those of sensitized Type 304 SS in very high-DO water (>6000 ppb DO).

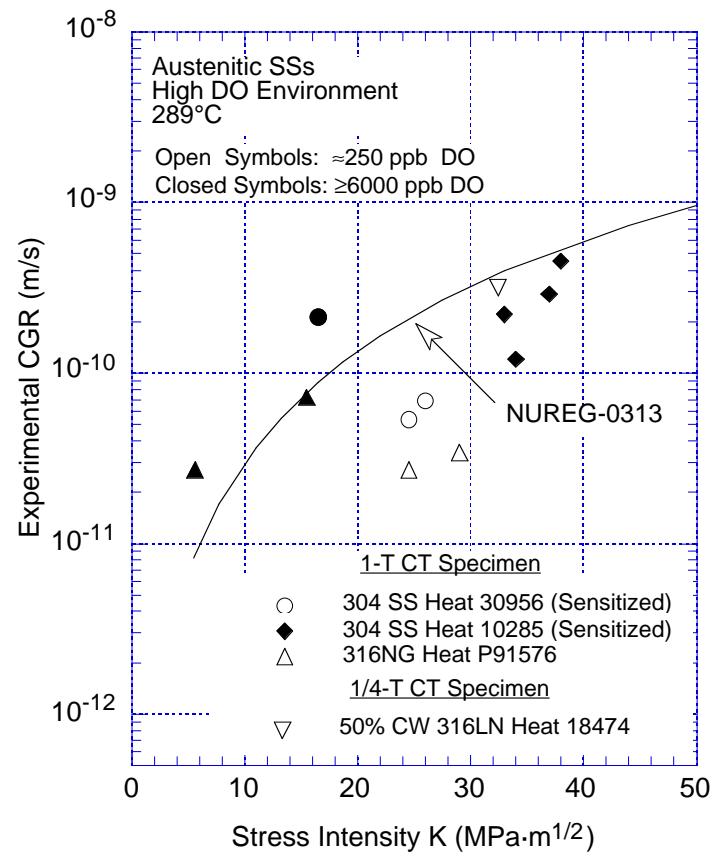

Figure 12.

Stress corrosion cracking data for austenitic stainless steels in high-DO water at $289^{\circ} \mathrm{C}$. 


\section{Results}

\subsection{Fracture Toughness}

\subsubsection{Nonirradiated Type 304 Stainless Steel}

The fracture toughness J-R curves for nonirradiated specimens of Heats L2, L20, C16, and $\mathrm{C} 19$, obtained in air by the DC potential and elastic unloading compliance methods, are shown in Figs. 13-16; experimental data for the tests are given in the Appendix. Duplicate tests were conducted for Heats L2 and C16. The results indicate that the fracture toughness of the laboratory Heats L2 and L20 is very low. The J-R curves are significantly lower than those typically observed for Type 304 SSs, Fig. 17. ${ }^{15,38-41}$ For wrought austenitic SSs, ${ }^{3}$ the $\mathrm{J}_{\text {Ic }}$ values at temperatures up to $550^{\circ} \mathrm{C}$ are typically $>400 \mathrm{~kJ} / \mathrm{m}^{2}$; experimental $\mathrm{J}_{\text {Ic }}$ for Heats L2 and $\mathrm{L} 20$ is in the range of $150-230$ and $80-120 \mathrm{~kJ} / \mathrm{m}^{2}$, respectively. The commercial Heats C16 and C19 show the very high fracture toughnesses expected for Type 304 SSs. For both steels, the J-R curve could not be obtained; the experimental curve is composed only of the blunting line. Fracture toughness $\mathrm{J}_{\mathrm{Ic}}$ is $>830 \mathrm{~kJ} / \mathrm{m}^{2}$ for $\mathrm{C} 19$, and it could not be determined for Heat C16.
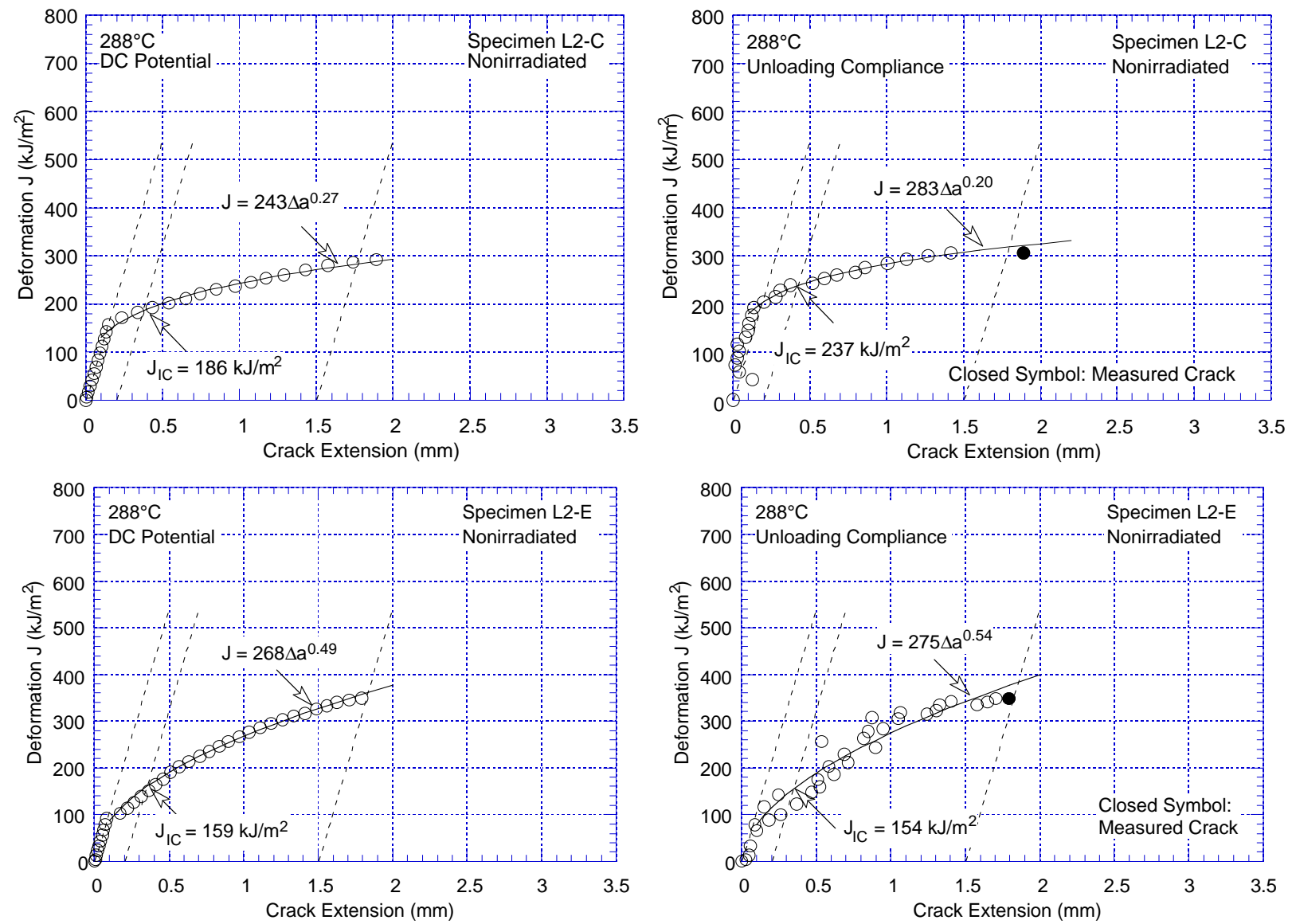

Figure 13. Fracture toughness $\mathrm{J}-\mathrm{R}$ curve obtained by DC potential and unloading compliance methods for nonirradiated specimens L2-C and L2-E of Heat L2 of Type 304 SS at $288^{\circ} \mathrm{C}$. 

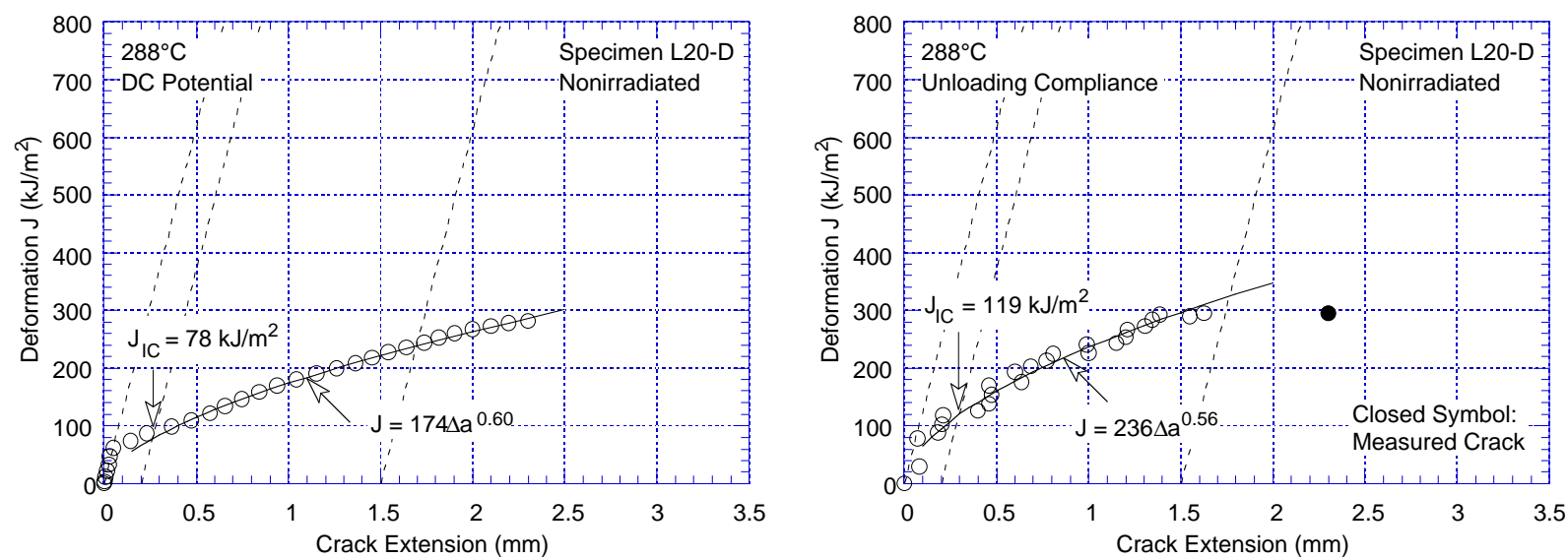

Figure 14. Fracture toughness $\mathrm{J}-\mathrm{R}$ curve obtained by DC potential and unloading compliance methods for nonirradiated specimen L20-D of Heat L20 of Type 304 SS at $288^{\circ} \mathrm{C}$.
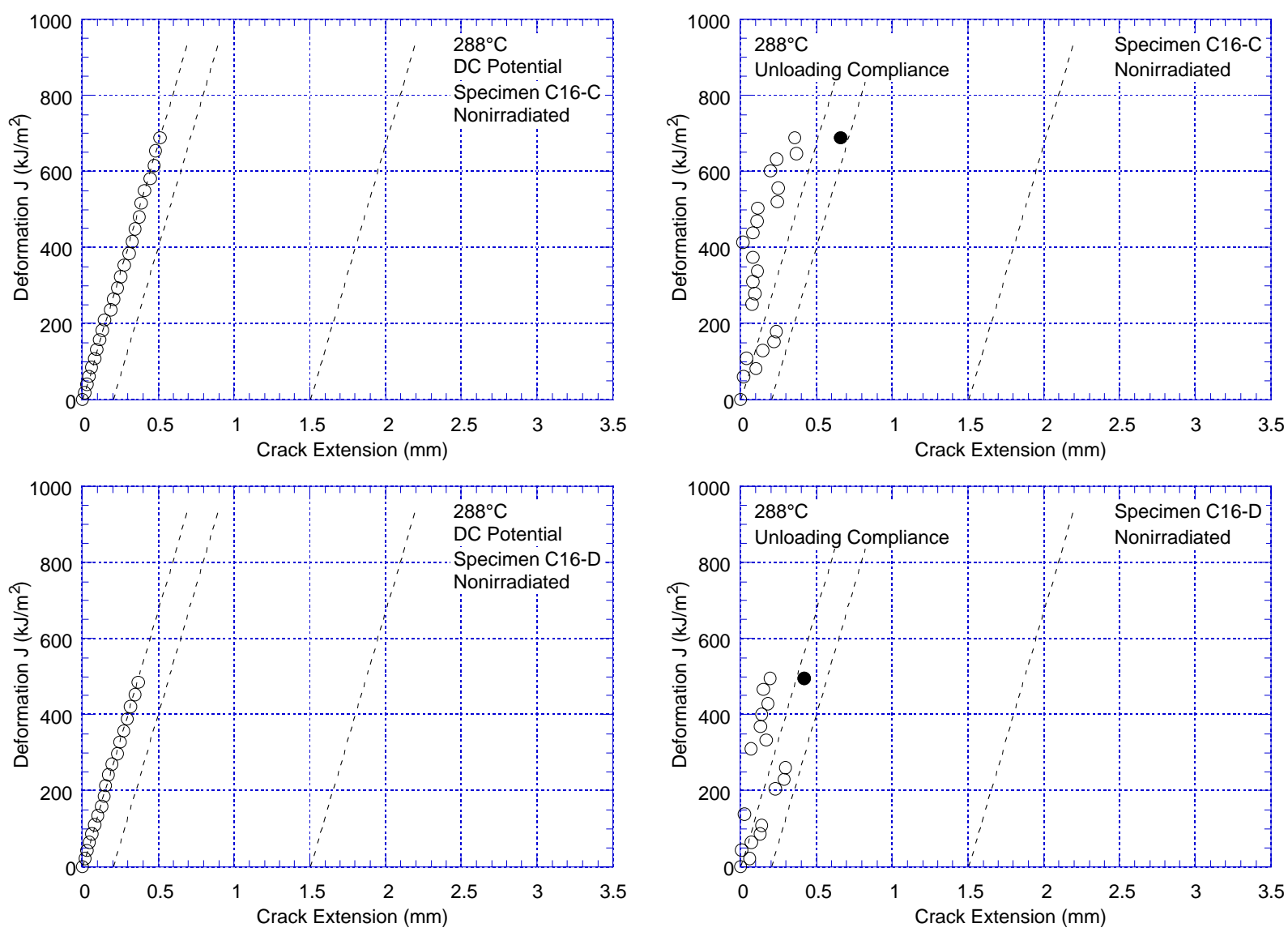

Figure 15. Fracture toughness $\mathrm{J}-\mathrm{R}$ curve obtained by DC potential and unloading compliance methods for nonirradiated specimens C16-C and C16-D of Heat C16 of Type 316 SS at $288^{\circ} \mathrm{C}$. 

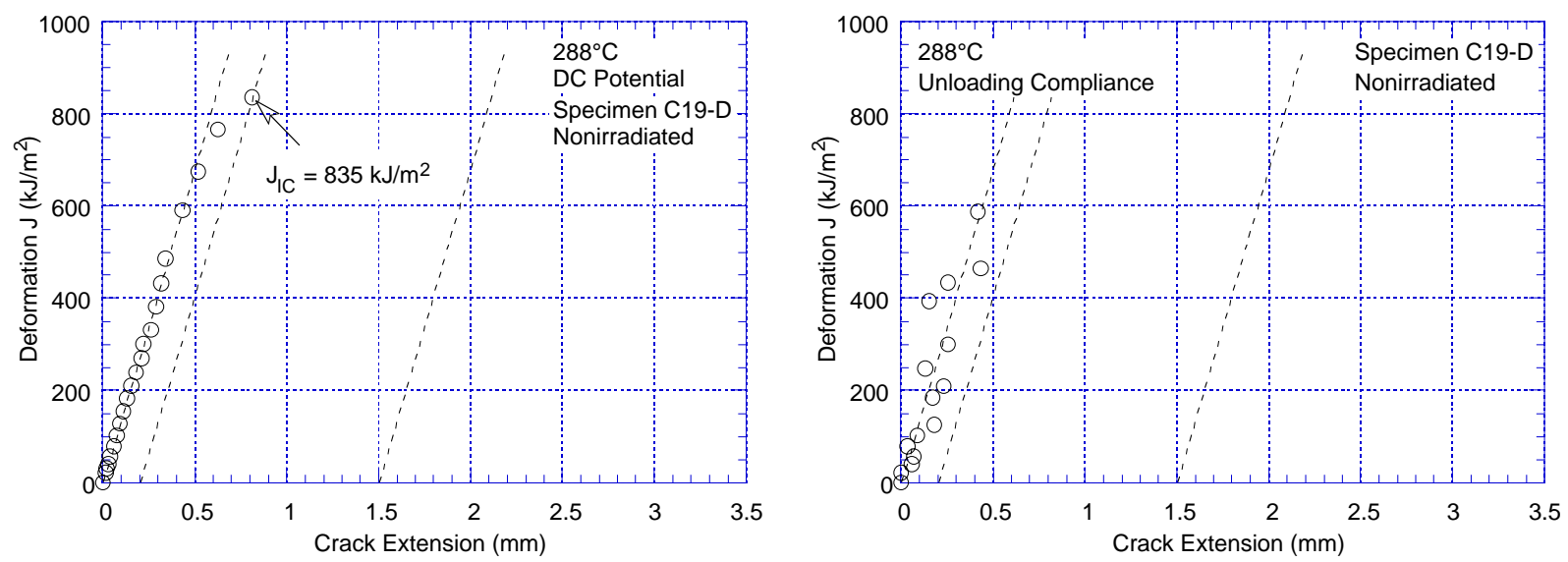

Figure 16. Fracture toughness $\mathrm{J}-\mathrm{R}$ curve obtained by DC potential and unloading compliance methods for nonirradiated specimen C19-D of Heat C19 of Type 304 SS at $288^{\circ} \mathrm{C}$.

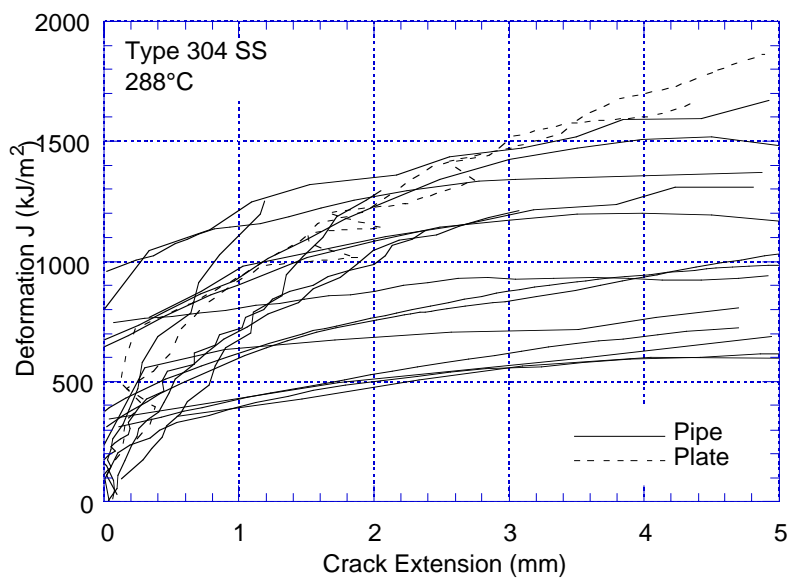

Figure 17.

Fracture toughness J-R curves for nonirradiated Type 304 stainless steels at $288^{\circ} \mathrm{C}$.

The differences between the fracture toughness of laboratory and commercial heats are reflected in their fracture behavior. Photomicrographs of the fracture surface of broken nonirradiated specimens of laboratory Heats L2 and L2O and commercial Heat C19 are shown in Figs. 18 and 19, respectively. Heat L2 contains relatively high S and P contents and many clusters of MnS inclusions. Failure occurs primarily via grain-boundary separation, which is

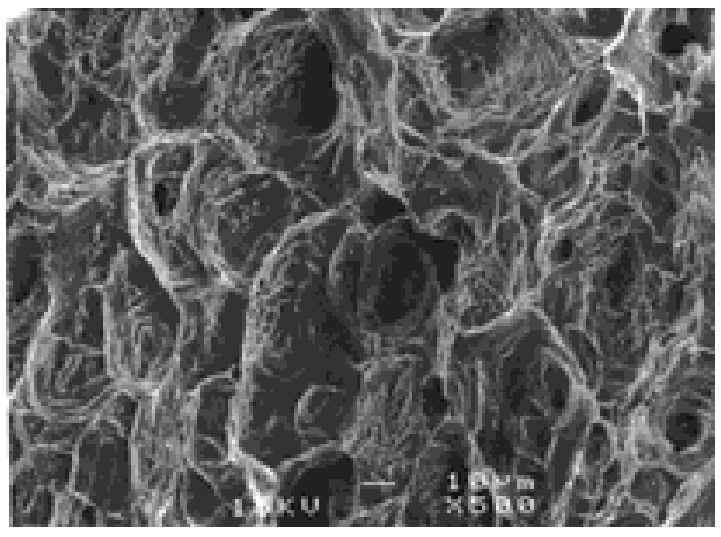

(a)

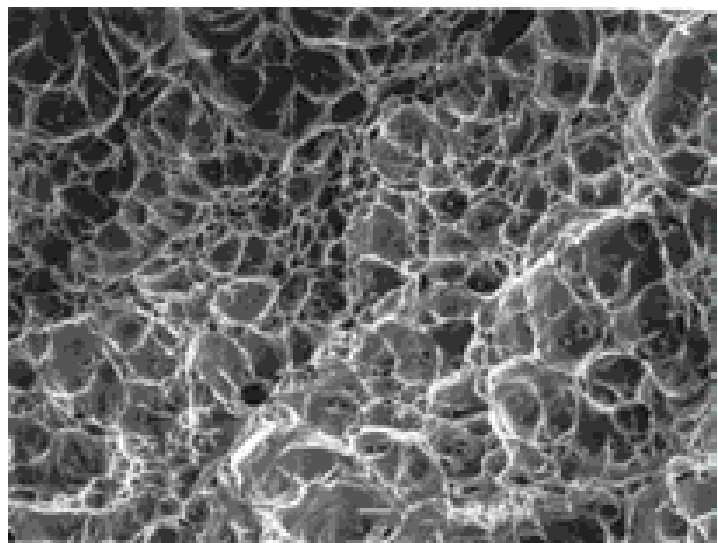

(b)

Figure 18. Photomicrographs of fracture surfaces of nonirradiated specimens of Heats (a) L2 and (b) L20 tested at $288^{\circ} \mathrm{C}$. 
accompanied by some plastic deformation and decohesion along the MnS clusters (Fig. 20). Heat L20 exhibits a dimple fracture; failure occurs by nucleation and growth of microvoids and rupture of remaining ligaments. Heat L20 contains relatively high oxygen and many oxide particle inclusions. In Fig. 18b, nearly every dimple appears to have been initiated by decohesion of an oxide inclusion. An identical fracture behavior was observed for Heat L20 irradiated to $0.9 \times 10^{21} \mathrm{n} \cdot \mathrm{cm}^{-2}(1.35 \mathrm{dpa})$. In contrast, commercial heats exhibit ductile failure with some dimple fracture, as shown for Heat C19 in Fig. 19.
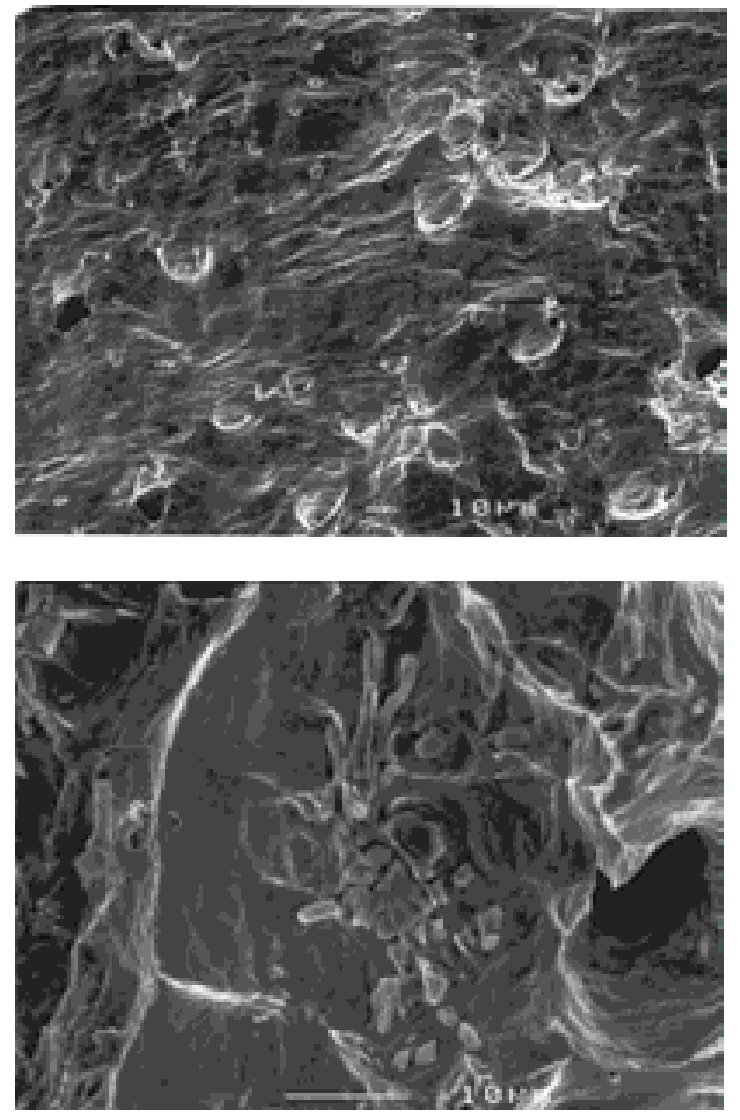

Figure 19 .

Photomicrograph of fracture surface of nonirradiated specimen of Heat C19 tested at $288^{\circ} \mathrm{C}$.
Figure 20.

Photomicrograph of MnS inclusions on the fracture surface of nonirradiated specimen of Heat L2 tested at $288^{\circ} \mathrm{C}$.

\subsubsection{Irradiated Type 304 Stainless Steels}

Fracture toughness J-R curve tests were conducted at $288^{\circ} \mathrm{C}$ on Heats C19, L20, and L2 of Type $304 \mathrm{SS}$ and Heat C16 of Type $316 \mathrm{SS}$ irradiated to $2.0 \times 10^{21} \mathrm{n} \cdot \mathrm{cm}^{-2}(\mathrm{E}>1 \mathrm{MeV})$ (3.0 dpa). The J-R curves for the various steels are shown in Figs. 21-24; experimental data for the tests are given in the Appendix. For specimen C19-C, the J-R curve could not be determined from the DC potential method because of broken potential leads. Note that the rather flat J-R curve determined for specimen C19-A most likely is due to the small specimen size used in these tests; the maximum allowed $\mathrm{J}$ values were exceeded for the test.

Neutron irradiation at $288^{\circ} \mathrm{C}$ decreases the fracture toughness of all steels. In general, fracture toughness of the commercial Heats C16 and C19 is superior to that of the laboratory Heats L2O and L2. These differences arise primarily from differences in toughness of the nonirradiated steels, i.e., the fracture toughness of the laboratory heats is significantly lower than that of the commercial heats. The fracture toughness J-R curves for irradiated Types 304 and 316 SS are comparable. 

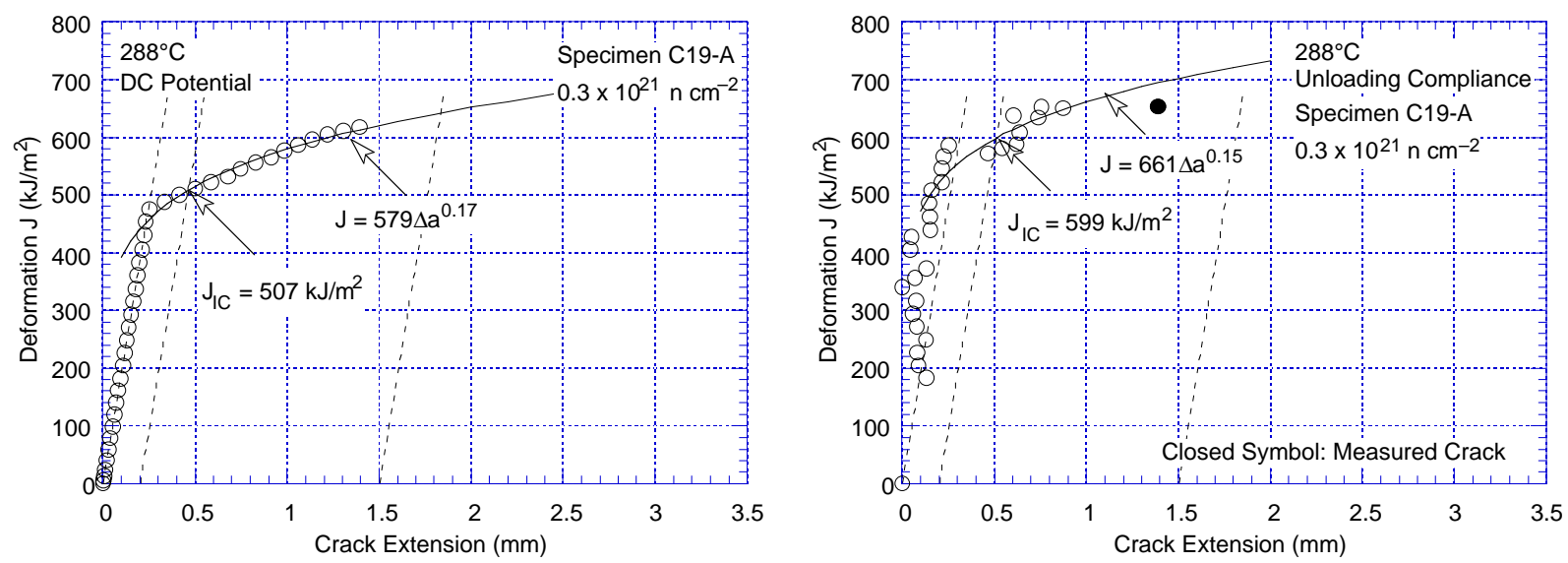

(a)
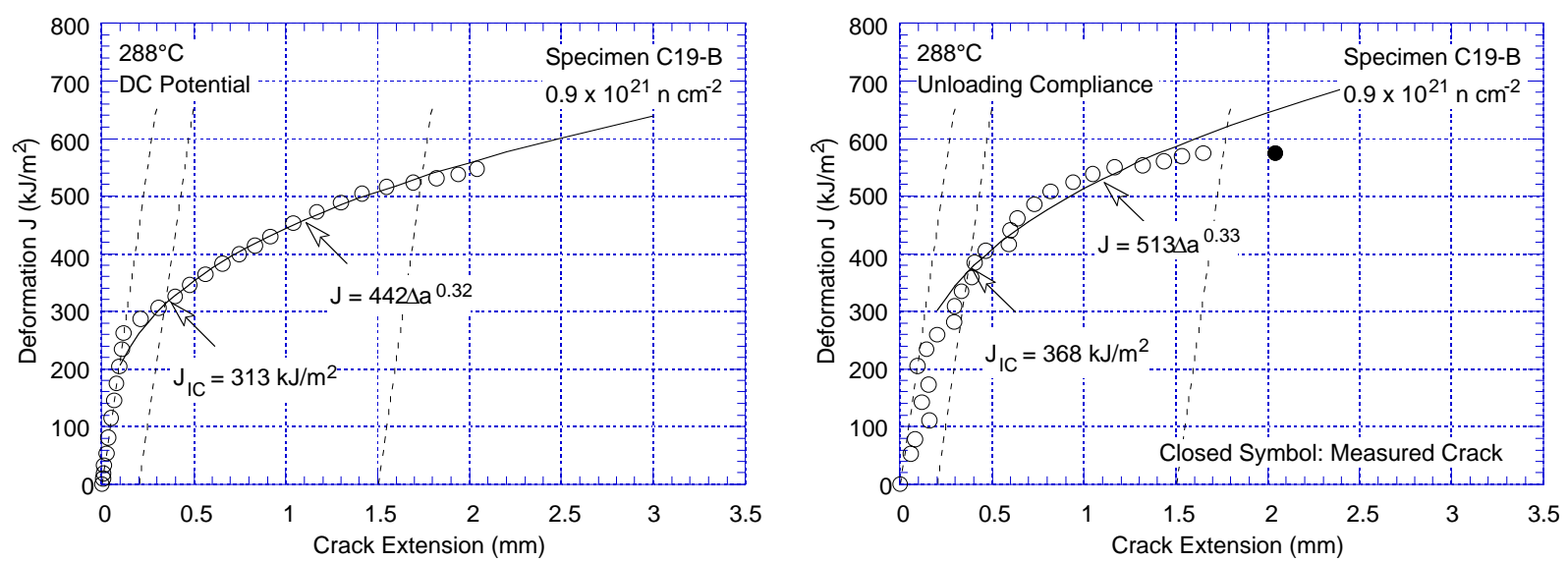

(b)

\section{Specimen C19-C - DC Potential method Data not obtained}

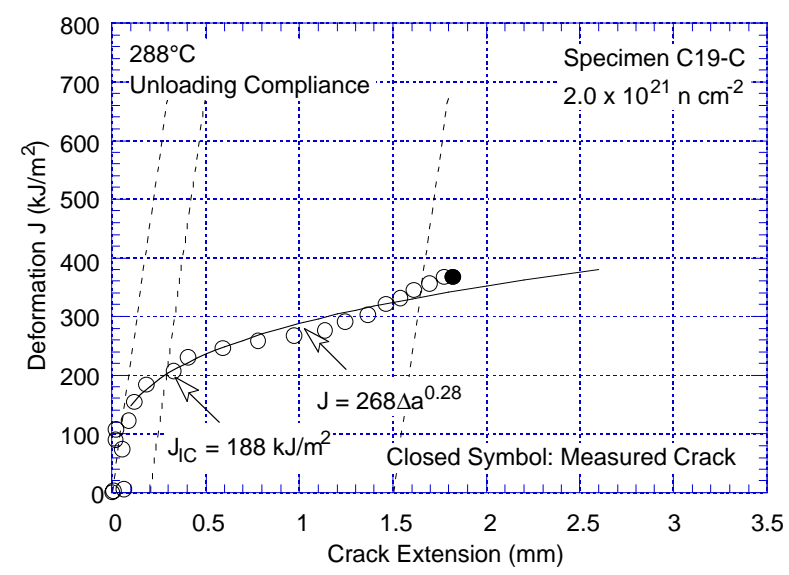

(c)

Figure 21. Fracture toughness $\mathrm{J}-\mathrm{R}$ curve obtained by DC potential and unloading compliance methods at $288^{\circ} \mathrm{C}$ for Heat $\mathrm{C} 19$ of Type 304 SS irradiated to a fluence level of (a) 0.3 , (b) 0.9 , and (c) $2.0 \times 10^{21} \mathrm{n} / \mathrm{cm}^{2}$. 

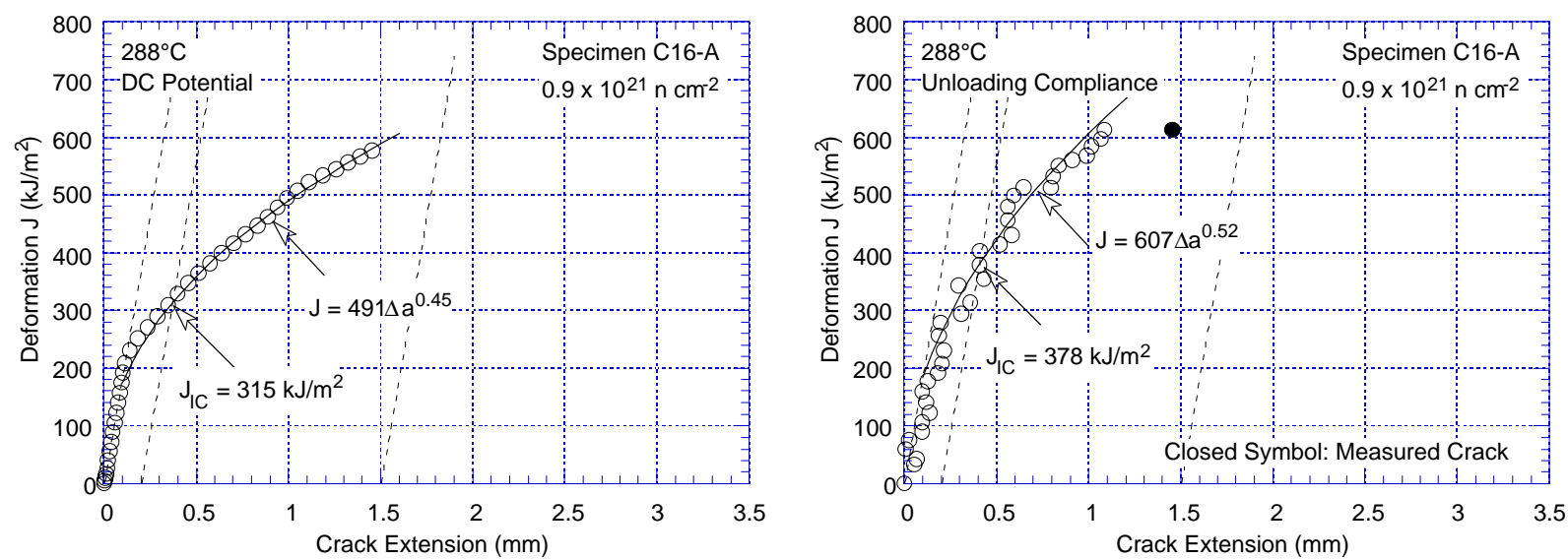

Figure 22. Fracture toughness $\mathrm{J}-\mathrm{R}$ curve obtained by DC potential and unloading compliance methods at $288^{\circ} \mathrm{C}$ for Heat $\mathrm{C} 16$ of Type $316 \mathrm{SS}$ irradiated to a fluence level of $0.9 \times 10^{21} \mathrm{n} / \mathrm{cm}^{2}$.
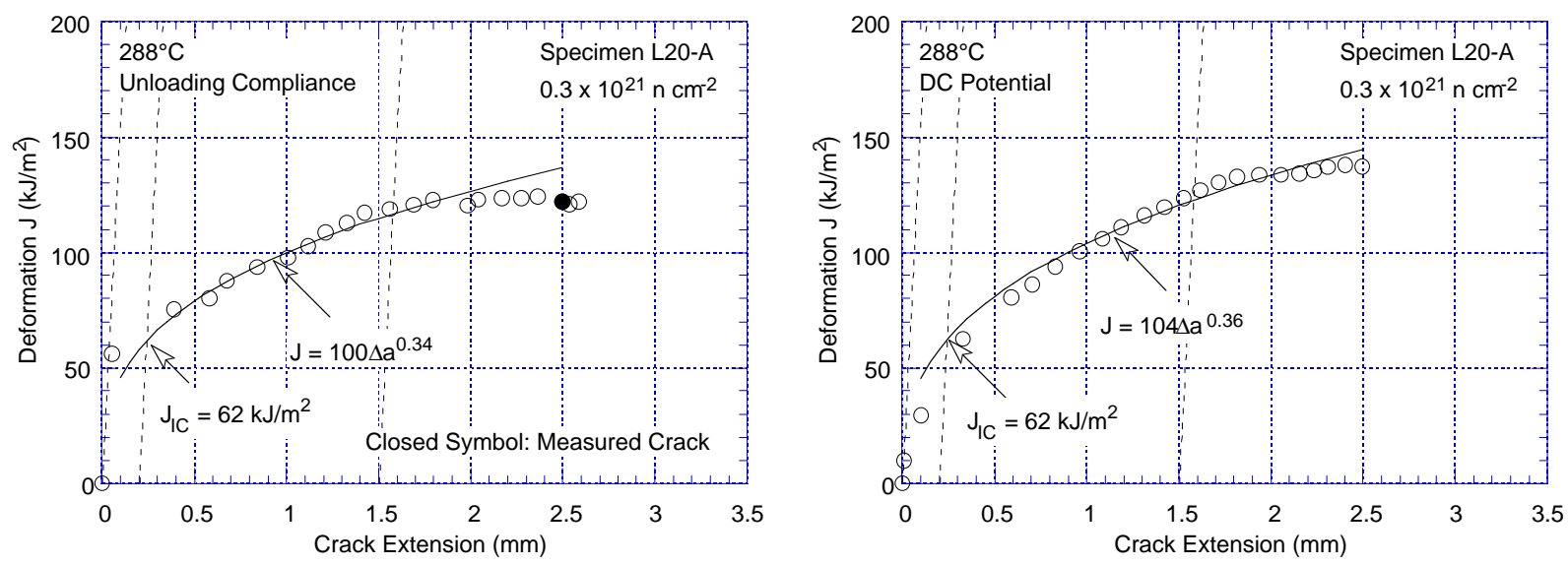

(a)
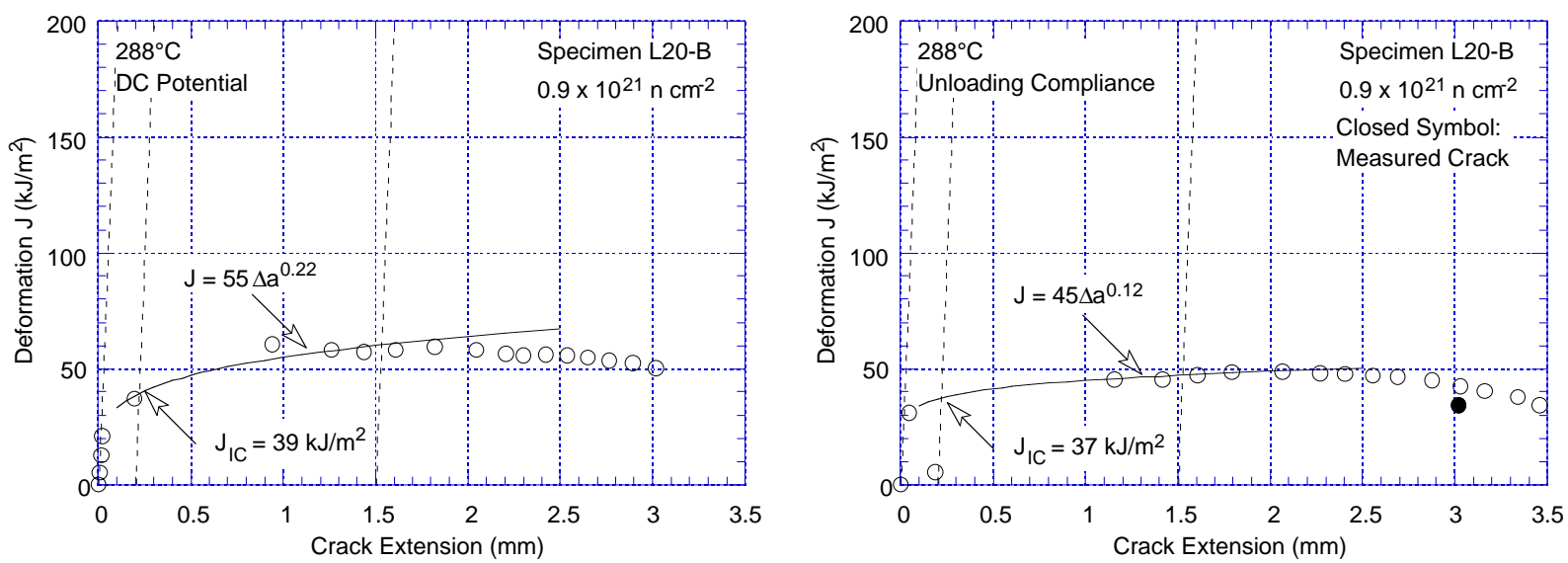

(b)

Figure 23. Fracture toughness $\mathrm{J}-\mathrm{R}$ curve obtained by DC potential and unloading compliance methods at $288^{\circ} \mathrm{C}$ for Heat L20 of Type 304 SS irradiated to a fluence level of (a) 0.3 and (b) $0.9 \times 10^{21} \mathrm{n} / \mathrm{cm}^{2}$. 

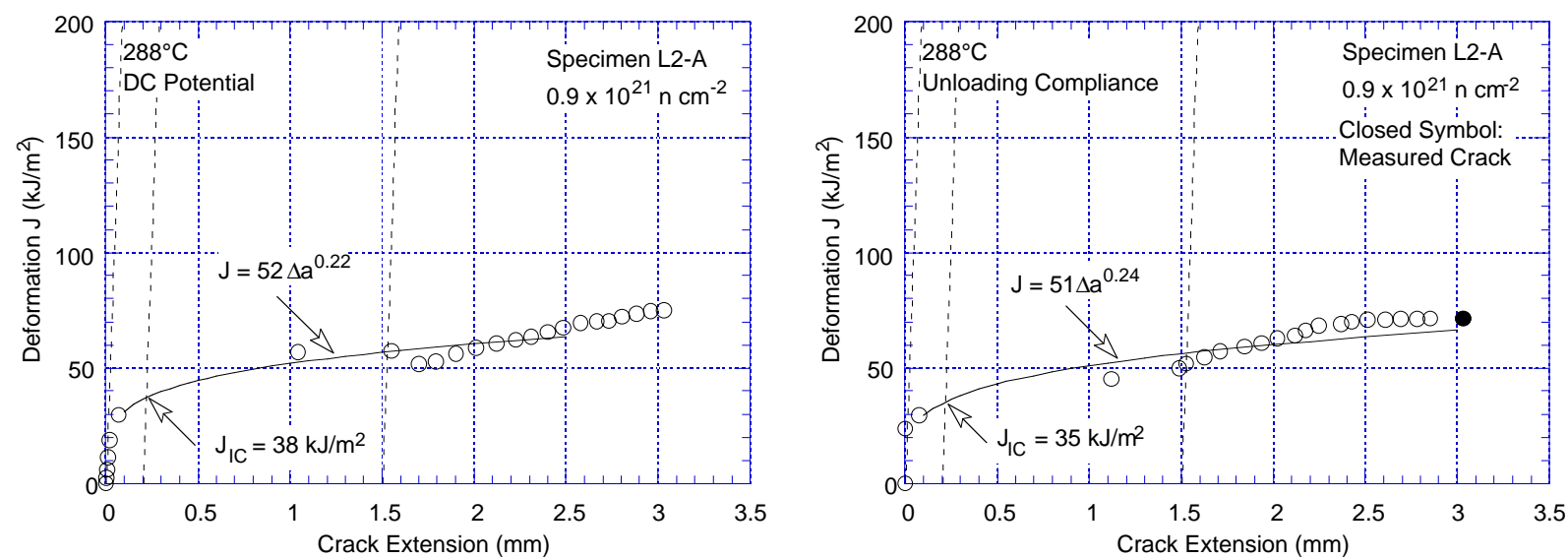

Figure 24. Fracture toughness $\mathrm{J}-\mathrm{R}$ curve obtained by DC potential and unloading compliance methods at $288^{\circ} \mathrm{C}$ for Heat L2 of Type 304 SS irradiated to a fluence level of $0.9 \times 10^{21} \mathrm{n} / \mathrm{cm}^{2}$.

The experimental $J_{\text {Ic }}$ values for the two commercial heats of austenitic SSs are plotted as a function of neutron exposure in Fig. 25. Results from tests on Type 304 SS reactor internal materials from operating BWRs ${ }^{2}$ are also included in the figure. All CT specimen data from commercial heats fall within the scatter band for the data obtained at temperatures higher than $288^{\circ} \mathrm{C}$.

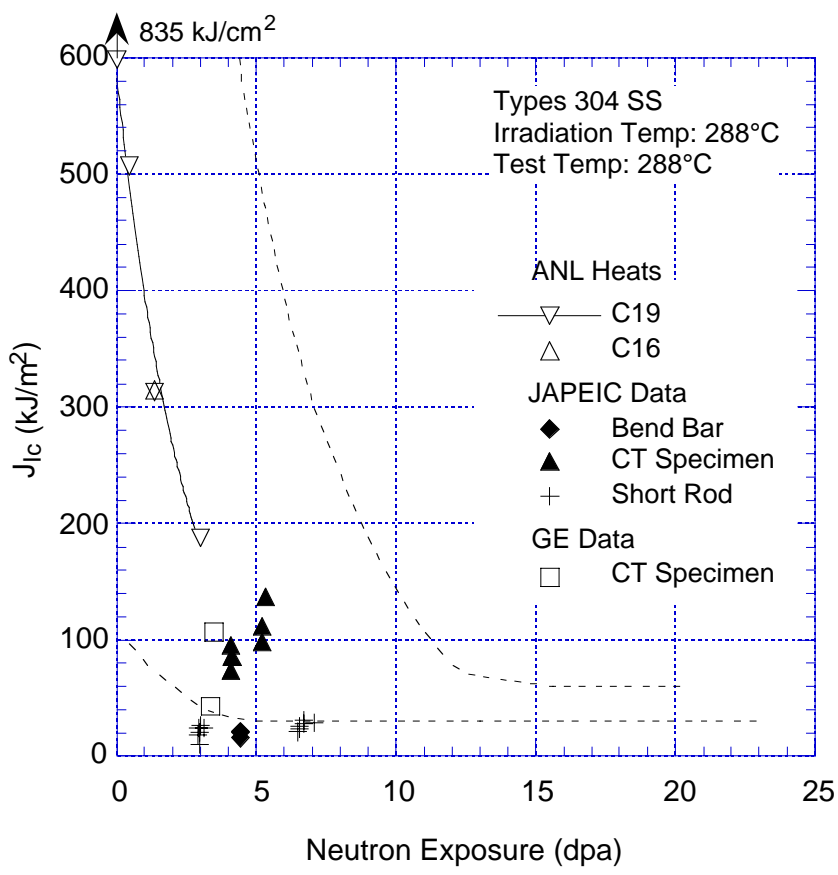

Figure 25.

Fracture toughness $J_{\mid c}$ of austenitic stainless steels as a function of neutron exposure at $288^{\circ} \mathrm{C}$. Dashed lines represent upper and lower bounds for change in $J_{\mathrm{IC}}$ for austenitic SSs irradiated at $350-450^{\circ} \mathrm{C}$.

JAPEIC = Japan Power Engineering and Inspection Corporation, GE = General Electric Nuclear Energy

\subsection{Crack Growth Tests on Irradiated Stainless Steels in BWR Environments}

Crack growth tests have been completed at $289^{\circ} \mathrm{C}$ on $1 / 4-\mathrm{T}$ CT specimens of Type 304 SS (Heat C3) irradiated to $0.3,0.9$, and $2.0 \times 10^{21} \mathrm{n} / \mathrm{cm}^{2}$ and Type $316 \mathrm{SS}$ (Heat C16) irradiated to $2.0 \times 10^{21} \mathrm{n} / \mathrm{cm}^{2}$. The significant results for the various tests are summarized below. 


\subsubsection{Specimen C3-B Irradiated to $0.9 \times 10^{21} \mathrm{n} / \mathrm{cm}^{2}$}

The environmental and loading conditions, experimental CGRs, allowed $\mathrm{K}_{\max }$ from $\mathrm{K} /$ size criterion in Eq. 13, and the deviation of applied $\mathrm{K}_{\max }$ from the allowed value are given in Table 3. Allowed $\mathrm{K}_{\max }$ was determined using effective yield stress in Eq. 13. Precracking was initiated at $\mathrm{R}=0.2$ and $\mathrm{K}_{\max }=16 \mathrm{MPa} \mathrm{m}^{1 / 2}$. During most test periods, $\mathrm{K}_{\max }$ was maintained approximately constant by periodic load shedding.

Table 3. Crack growth results for Specimen C3-B of Type $304 \mathrm{SS}^{\mathrm{a}}$ in high-purity water at $289^{\circ} \mathrm{C}$

\begin{tabular}{|c|c|c|c|c|c|c|c|c|c|c|c|c|c|}
\hline \multirow{2}{*}{$\begin{array}{c}\text { Test } \\
\text { Period }\end{array}$} & \multirow{2}{*}{$\begin{array}{c}\text { Test } \\
\text { Time, } \\
\mathrm{h}\end{array}$} & \multicolumn{2}{|c|}{$\begin{array}{c}\mathrm{ECP} \\
\mathrm{mV}(\mathrm{SHE})^{\mathrm{b}}\end{array}$} & \multirow{2}{*}{$\begin{array}{c}\mathrm{O}_{2} \\
\text { Conc., } \\
\text { ppb }\end{array}$} & \multirow{2}{*}{$\begin{array}{l}\text { Load } \\
\text { Ratio }\end{array}$} & \multirow{2}{*}{$\begin{array}{c}\text { Rise } \\
\text { Time, } \\
\text { s }\end{array}$} & \multirow{2}{*}{$\begin{array}{c}\text { Down } \\
\text { Time, } \\
\text { s }\end{array}$} & \multirow{2}{*}{$\begin{array}{c}\text { Hold } \\
\text { Time, } \\
\text { s }\end{array}$} & \multirow{2}{*}{$\begin{array}{c}\mathrm{K}_{\max } \\
\mathrm{MPa} \cdot \mathrm{m}^{1 / 2}\end{array}$} & \multirow{2}{*}{$\begin{array}{c}\Delta \mathrm{K}, \\
\mathrm{MPa} \cdot \mathrm{m}^{1 / 2}\end{array}$} & \multirow{2}{*}{$\begin{array}{c}\text { Growth } \\
\text { Rate, } \\
\text { m/s }\end{array}$} & \multirow{2}{*}{$\begin{array}{c}\mathrm{K}_{\max } \text { from } \\
\text { Eq. } 13 \\
\text { MPa } \mathrm{m}^{1 / 2}\end{array}$} & \multirow{2}{*}{$\begin{array}{c}\text { Deviation } \\
\text { in } \mathrm{K}_{\max } \text {, } \\
\%\end{array}$} \\
\hline & & $\mathrm{Pt}$ & Steel & & & & & & & & & & \\
\hline 1 & 28 & 230 & 154 & 300 & 0.20 & 0.5 & 0.5 & 0 & 19.14 & 15.31 & $6.83 \mathrm{E}-08$ & 18.4 & 4 \\
\hline 2 & 172 & 239 & 189 & 300 & 0.51 & 60 & 2 & 0 & 18.96 & 9.29 & $1.75 \mathrm{E}-10$ & 18.3 & 3 \\
\hline 3 & 287 & 233 & 187 & 300 & 0.70 & 300 & 2 & 0 & 19.79 & 5.94 & $6.38 \mathrm{E}-10$ & 18.0 & 10 \\
\hline 4 & 335 & 235 & 191 & 300 & 0.70 & 2 & 2 & 7200 & 20.10 & 0 & $1.06 \mathrm{E}-09$ & 17.7 & 14 \\
\hline 5 & 376 & 238 & 195 & 300 & 0.70 & 2 & 2 & 7200 & 22.07 & 0 & $1.04 \mathrm{E}-09$ & 17.4 & 27 \\
\hline 6 & 624 & -475 & -595 & $\approx 10$ & 0.70 & 2 & 2 & 7200 & 22.27 & 0 & $4.02 \mathrm{E}-11$ & 17.2 & 30 \\
\hline 7 & 696 & -482 & -607 & $\approx 10$ & 0.70 & 300 & 2 & 0 & 22.10 & 6.63 & $8.56 \mathrm{E}-11$ & 17.1 & 29 \\
\hline 8 & 935 & -495 & -614 & $\approx 10$ & 0.70 & 2 & 2 & 3600 & 22.66 & 0 & $6.42 \mathrm{E}-12$ & 17.1 & 32 \\
\hline 9 & 1031 & -499 & -609 & $\approx 10$ & 0.70 & 300 & 2 & 0 & 22.53 & 6.76 & $3.37 \mathrm{E}-11$ & 17.1 & 32 \\
\hline $10 \mathrm{a}$ & 1127 & -495 & -613 & $\approx 10$ & 0.70 & 1000 & 2 & 0 & 22.19 & 6.66 & negligible & 17.1 & 30 \\
\hline $10 \mathrm{~b}$ & 1271 & -507 & -620 & $\approx 10$ & 0.70 & 1000 & 2 & 0 & 23.04 & 6.91 & $1.20 \mathrm{E}-11$ & 17.1 & 35 \\
\hline 11 & 1295 & -507 & -624 & $\approx 10$ & 0.70 & 30 & 2 & 0 & 22.87 & 6.86 & $5.17 \mathrm{E}-11$ & 17.1 & 34 \\
\hline 12 & 1343 & -498 & -617 & $\approx 10$ & 0.70 & 300 & 2 & 0 & 23.10 & 6.93 & $1.55 \mathrm{E}-11$ & 17.1 & 36 \\
\hline 14 & 1608 & 248 & 151 & 250 & 0.70 & 1000 & 2 & 0 & 24.17 & 7.25 & $5.93 \mathrm{E}-10$ & 16.7 & 45 \\
\hline 15 & 1655 & 244 & 155 & 250 & 0.70 & 2 & 2 & 3600 & 24.42 & 0 & $8.70 \mathrm{E}-10$ & 16.4 & 49 \\
\hline
\end{tabular}

${ }^{\mathrm{a}}$ Heat C3, irradiated to $0.9 \times 10^{21} \mathrm{n} \mathrm{cm}^{-2}$.

${ }^{b}$ Represents values in the effluent.

Conductivity was 0.07 and $0.3-0.45 \mu \mathrm{S} / \mathrm{cm}$ in feedwater and effluent, respectively. Feedwater $\mathrm{pH}$ at room temperature was 6.5 .

The test was initiated in high-purity water with $\approx 300 \mathrm{ppb}$ DO. After $\approx 375 \mathrm{~h}$, the DO level in the feedwater was decreased to $\approx 10 \mathrm{ppb}$ by sparging it with pure nitrogen. After $1380 \mathrm{~h}$, the DO level was increased from $\approx 10$ to $\approx 300 \mathrm{ppb}$ by sparging the feedwater with nitrogen plus $1 \%$ oxygen gas mixture. Because of the very low flow rates for the recirculating water system it took several days for the environmental conditions to stabilize. Changes in crack length and ECP of Pt and SS electrodes during these transient periods are shown in Fig. 26. During the transition periods, changes in the steel ECP were slower than those in the Pt ECP. For example, in Fig. 26a, although the Pt ECP decreased below $-400 \mathrm{mV}$ (SHE) within $40 \mathrm{~h}$, it took more than $150 \mathrm{~h}$ for the steel ECP to decrease below $-400 \mathrm{mV}$. Also, because of an unexpected power bump the test tripped after $\approx 1390 \mathrm{~h}$ (during the second transition period); it was restarted at $1470 \mathrm{~h}$. The ECPs of both electrodes were below $-200 \mathrm{mV}$ before the interruption and above $100 \mathrm{mV}$ after the test was restarted.

A photomicrograph of the fracture surface of both halves of the specimen is shown in Fig. 27. The final crack length, determined from the photograph, showed very good agreement with the value estimated from the DC potential measurements. Changes in crack length and $\mathrm{K}_{\max }$ with time during various test periods are shown in Fig. 28a-e. In general, the DC potential measurements show very little scatter, particularly for measured growth rates $>5 \times 10^{-11} \mathrm{~m} / \mathrm{s}$. Some fluctuations in DC potential measurements were observed when either the autoclave temperature varied $\pm 3^{\circ} \mathrm{C}$ (e.g., 170-260 h) or the DO level in the water was being changed (e.g., 450-530 $\mathrm{h}$ and 1370-1510 h). 


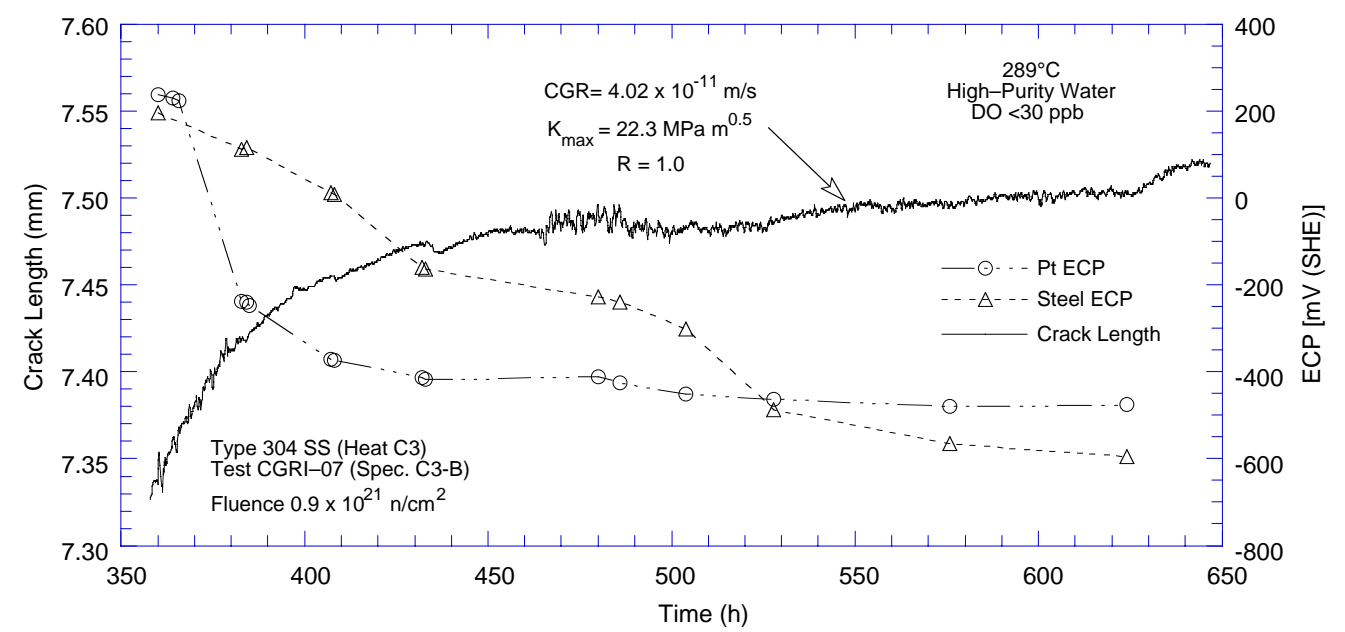

(a)

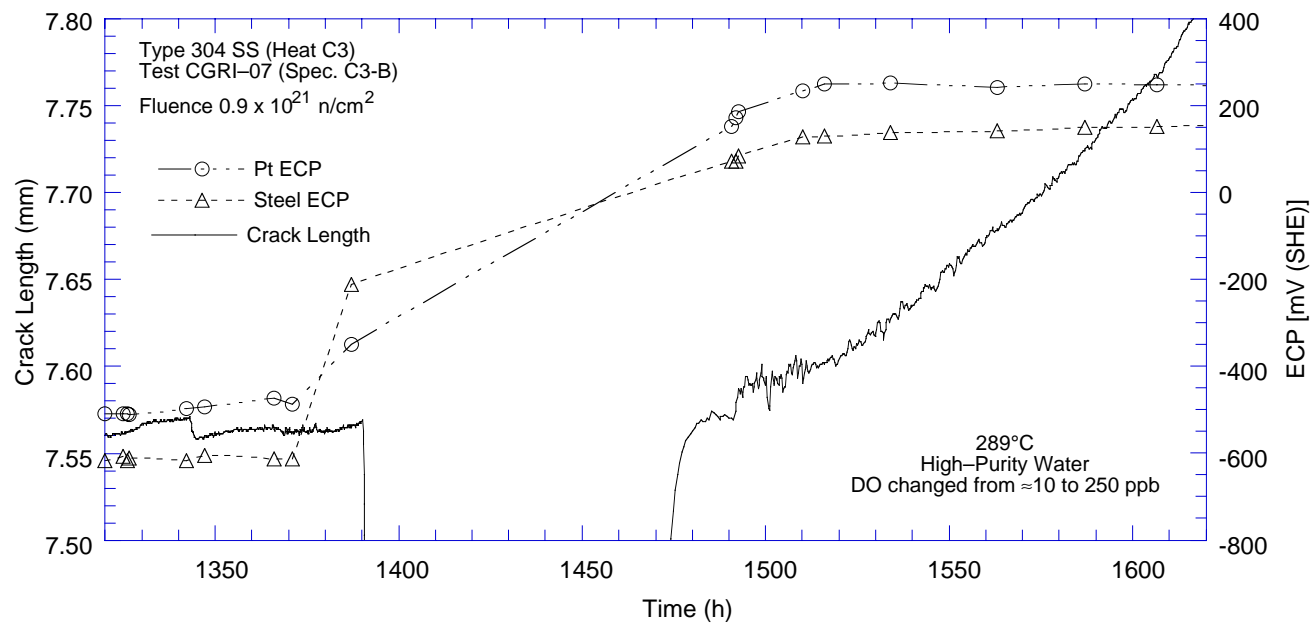

(b)

Figure 26. Changes in crack length and ECP after the dissolved oxygen level in the feedwater was (a) decreased from $\approx 500$ to $10 \mathrm{ppb}$ and (b) increased from $\approx 10$ to $300 \mathrm{ppb}$

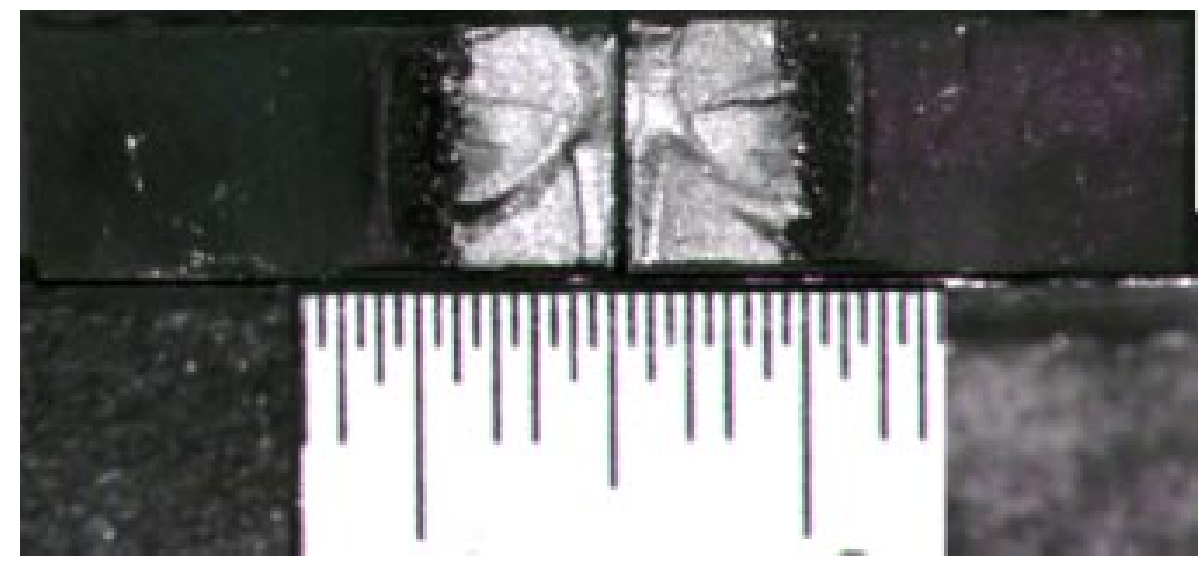

Figure 27. Photomicrographs of the fracture surface of specimen $\mathrm{C} 3-\mathrm{B}$ tested in high-purity water at $289^{\circ} \mathrm{C}$ 


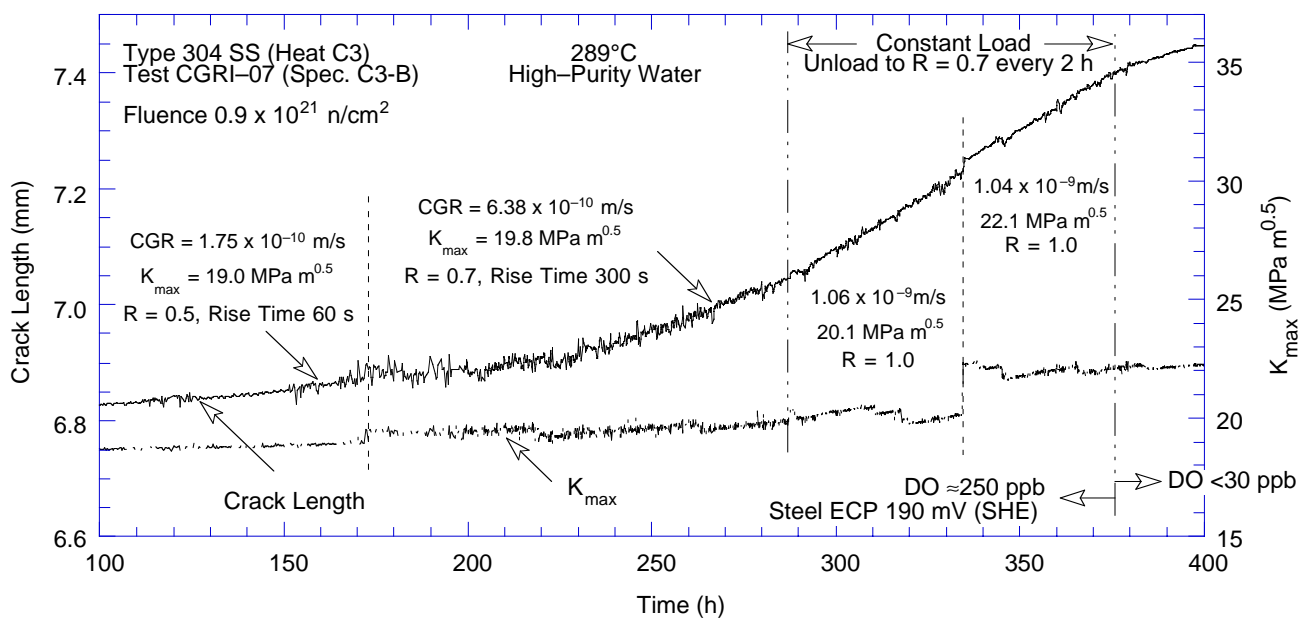

(a)

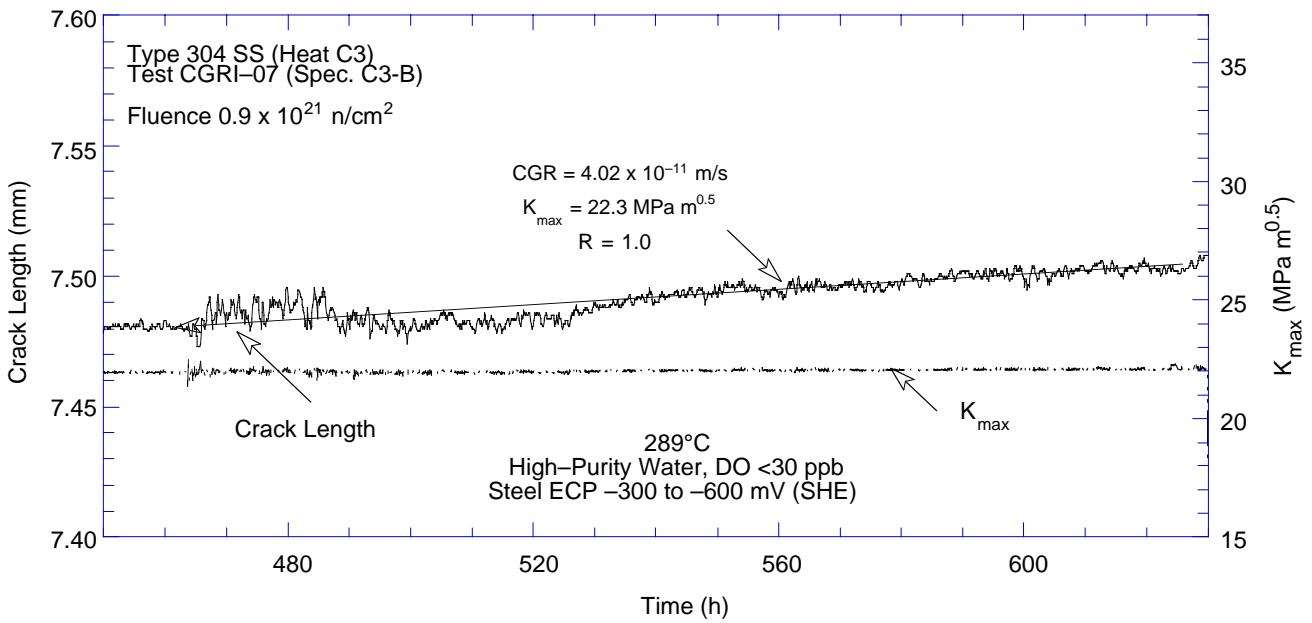

(b)

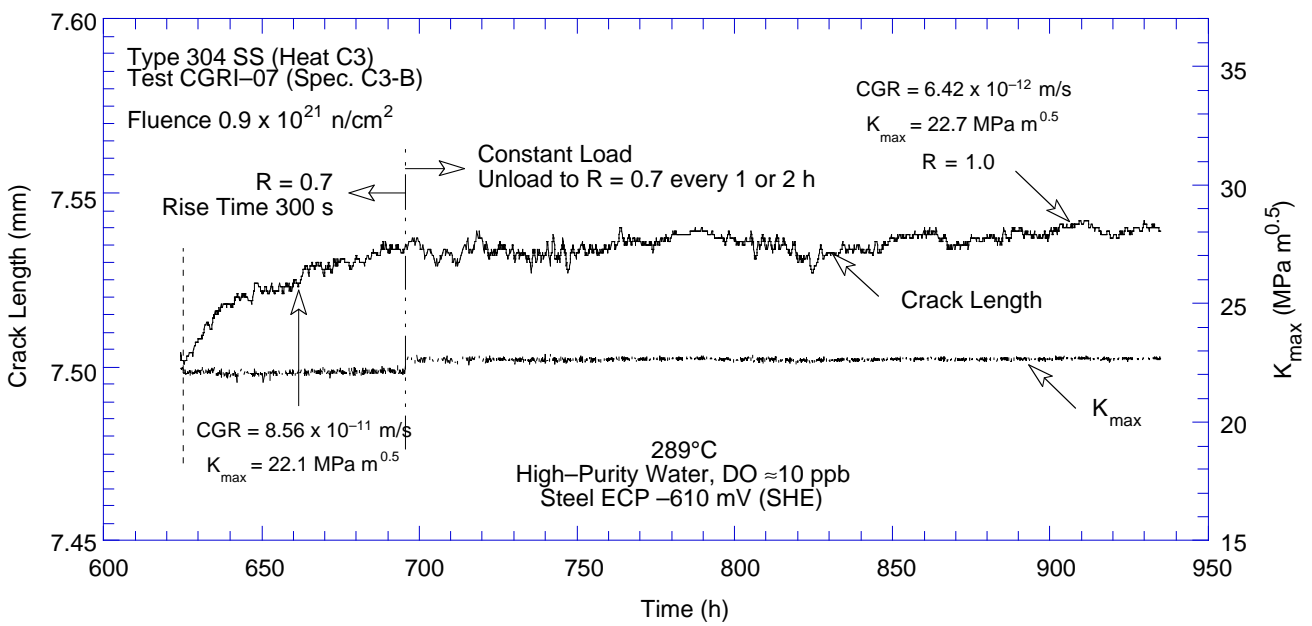

(c)

Figure 28. Crack-length-vs.-time plots for irradiated Type 304 SS (Heat C3) in high-purity water at $289^{\circ} \mathrm{C}$ during test periods (a) 2-5, (b) 6, (c) 7-8, (d) 9-12, and (e) 14-15 


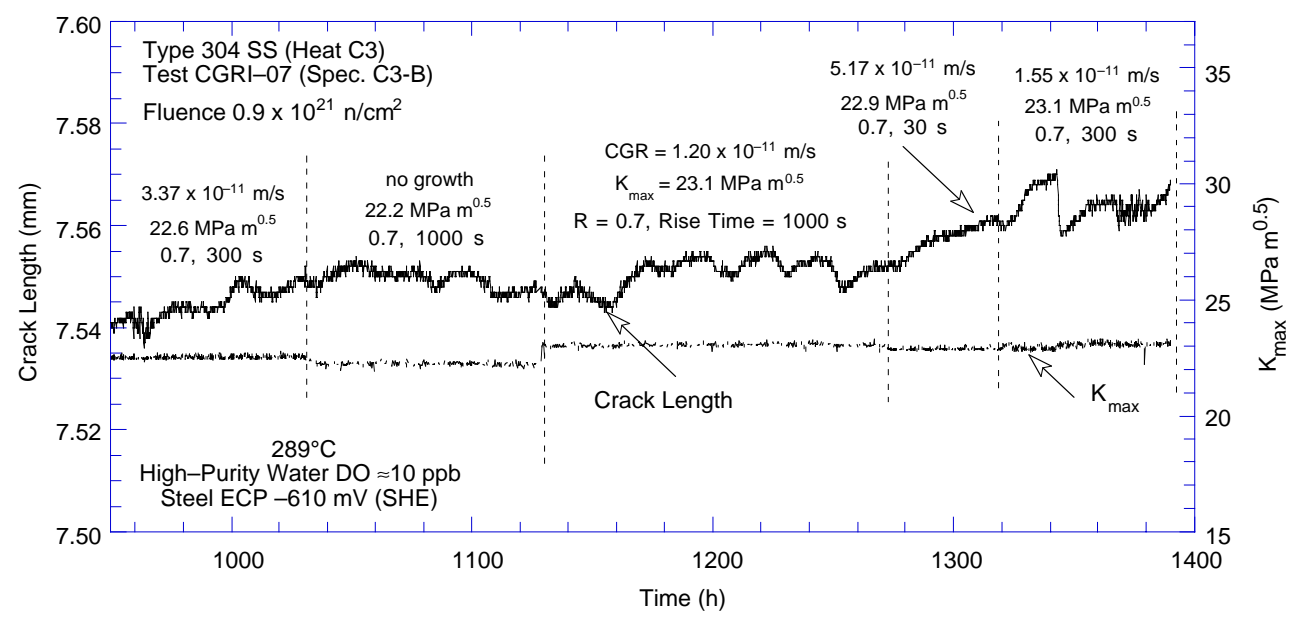

(d)

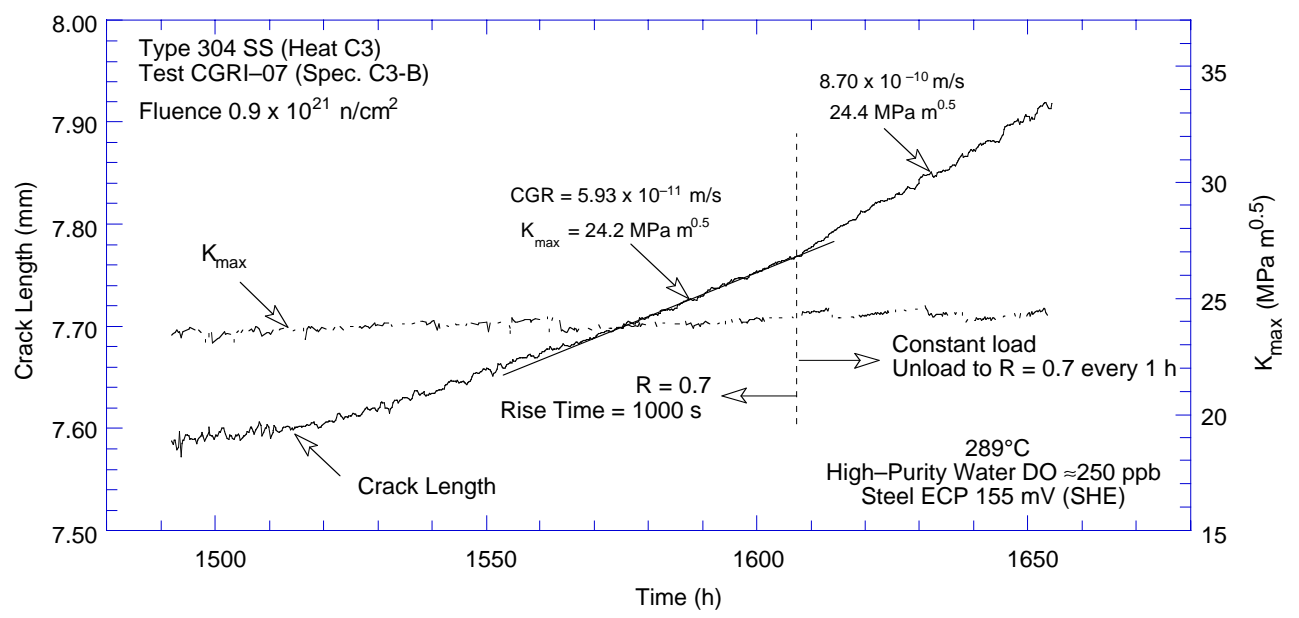

(e)

Figure 28. (Cont'd.)

For this specimen, environmental enhancement occurred after $\approx 170 \mathrm{~h}$ (Fig. 28a), when the load ratio and rise time, respectively, were changed from 0.5 and $60 \mathrm{~s}$ to 0.7 and $300 \mathrm{~s}$. For the new loading condition, although the predicted CGR in air decreased by a factor of $\approx 15$ (Eqs. 15-17), the measured rate in the environment increased by a factor of $\approx 3$. The results indicate the benefit of low-DO environment on growth rates; CGRs decreased by more than an order of magnitude when the DO level was decreased to $<10 \mathrm{ppb}$ and increased when the DO level was raised back to $\approx 300 \mathrm{ppb}$.

The results also suggest a possible effect of loading history on growth rates, e.g., during test periods 6 and 8, the CGRs under the same trapezoidal waveform were $4.0 \times 10^{-11}$ and $6.4 \times 10^{-12} \mathrm{~m} / \mathrm{s}$, respectively. The higher rate was observed following a long period of growth at a higher ECP under a trapezoidal waveform. The lower rate was observed following cycling under a sawtooth waveform with a 300-s rise time at low DO. It is possible that the cyclic loading changed the mode of fracture. The reason for such apparent differences in CGRs under similar loading conditions will be investigated by metallographic evaluation of the fracture surfaces; if a transition in fracture mode is observed, additional precautions to avoid such transitions will be observed in future tests. 
For specimen C3-B, during Test Periods 1-4 the experimental $\mathrm{K}_{\max }$ values were 4-14\% higher than the allowable value based on the effective yield stress and 30-50\% higher during Periods 5-15. For this specimen, loading conditions for all test periods would satisfy the K/size criterion of Eq. 13 if the actual yield stress instead of effective yield stress is used. The crack-length-vs.-time plots in Figs. 26a and 28a and b show that environmental factors still strongly influenced the CGR at these $\mathrm{K}$ levels. For example, the CGRs decreased by a factor of $\approx 20$ when the DO level was decreased from $\approx 300$ to $10 \mathrm{ppb}$. Thus in this case, it is not clear that the violation of the $\mathrm{K}$ size criterion after Test Period 3 actually led to a significant loss of specimen constraint.

\subsubsection{Specimen C3-C Irradiated to $2.0 \times 10^{21} \mathrm{n} / \mathrm{cm}^{2}$}

The environmental and loading conditions, experimental CGRs, allowed $\mathrm{K}_{\max }$ from $\mathrm{K} /$ size criterion in Eq. 13, and the deviation of applied $\mathrm{K}_{\max }$ from the allowed value are given in Table 4. Allowed $\mathrm{K}_{\max }$ was determined using effective yield stress. Precracking was carried out at $\mathrm{R}=0.3$ and $\mathrm{K}_{\max }=17 \mathrm{MPa} \mathrm{m}^{1 / 2}$; the applied $\mathrm{K}_{\max }$ was maintained approximately constant during individual test periods by periodic load shedding. The test was initiated in high-purity water with $\approx 300 \mathrm{ppb}$ DO. After $\approx 240 \mathrm{~h}$, the DO level in the feedwater was decreased to $\approx 10 \mathrm{ppb}$ by sparging the feedwater tank first with pure nitrogen and then with nitrogen plus $5 \%$ hydrogen. The changes in crack length and ECP of Pt and SS electrodes during the transient period are shown in Fig. 29. As seen earlier for Specimen C3-B, it took several days for the DO level to decrease below $20 \mathrm{ppb}$, and changes in the steel ECP were slower than that in the Pt ECP. For example, the Pt ECP decreased to $-450 \mathrm{mV}$ (SHE) within a couple of days while the steel ECP remained above $-250 \mathrm{mV}$ for a long time; it decreased below $-400 \mathrm{mV}$ only after the feedwater tank was sparged with nitrogen plus 5\% hydrogen gas mixture. The test was terminated after $810 \mathrm{~h}$ because the range of valid $\mathrm{K}_{\max }$ was significantly exceeded.

Table 4. Crack growth results for Specimen C3-C of Type $304 \mathrm{SS}^{\mathrm{a}}$ in high-purity water at $289^{\circ} \mathrm{C}$

\begin{tabular}{|c|c|c|c|c|c|c|c|c|c|c|c|c|c|}
\hline \multirow{2}{*}{$\begin{array}{c}\text { Test } \\
\text { Period }\end{array}$} & \multirow{2}{*}{$\begin{array}{c}\text { Test } \\
\text { Time, } \\
\mathrm{h}\end{array}$} & \multicolumn{2}{|c|}{$\begin{array}{c}\text { ECP } \\
\mathrm{mV}(\mathrm{SHE})^{\mathrm{b}}\end{array}$} & \multirow{2}{*}{$\begin{array}{c}\mathrm{O}_{2} \\
\text { Conc., } \\
\text { ppb }\end{array}$} & \multirow{2}{*}{$\begin{array}{l}\text { Load } \\
\text { Ratio }\end{array}$} & \multirow{2}{*}{$\begin{array}{l}\text { Rise } \\
\text { Time, } \\
\text { s }\end{array}$} & \multirow{2}{*}{$\begin{array}{c}\text { Down } \\
\text { Time, } \\
\text { s }\end{array}$} & \multirow{2}{*}{$\begin{array}{l}\text { Hold } \\
\text { Time, } \\
\text { s }\end{array}$} & \multirow{2}{*}{$\begin{array}{c}\mathrm{K}_{\max } \\
\mathrm{MPa} \cdot \mathrm{m}^{1 / 2}\end{array}$} & \multirow{2}{*}{$\begin{array}{c}\Delta \mathrm{K} \\
\mathrm{MPa} \cdot \mathrm{m}^{1 / 2}\end{array}$} & \multirow{2}{*}{$\begin{array}{c}\text { Growth } \\
\text { Rate, } \\
\text { m/s }\end{array}$} & \multirow{2}{*}{$\begin{array}{l}\mathrm{K}_{\max } \text { from } \\
\text { Eq. } 13 \\
\text { MPa } \mathrm{m}^{1 / 2}\end{array}$} & \multirow{2}{*}{$\begin{array}{c}\text { Deviation } \\
\text { in } \mathrm{K}_{\max } \text {, } \\
\%\end{array}$} \\
\hline & & $\mathrm{Pt}$ & Steel & & & & & & & & & & \\
\hline 1 & 46 & 241 & 164 & 300 & 0.26 & 2 & 2 & 0 & 17.89 & 13.24 & $2.00 \mathrm{E}-08$ & 22.4 & -20 \\
\hline 2 & 71 & 223 & 155 & 300 & 0.53 & 30 & 2 & 0 & 18.40 & 8.65 & $2.22 \mathrm{E}-09$ & 22.1 & -17 \\
\hline 3 & 99 & 235 & 167 & 300 & 0.70 & 300 & 2 & 0 & 18.80 & 5.64 & $1.73 \mathrm{E}-09$ & 21.8 & -14 \\
\hline 4 & 142 & 232 & 164 & 300 & 0.69 & 1000 & 2 & 0 & 19.21 & 5.96 & $1.25 \mathrm{E}-09$ & 21.4 & -10 \\
\hline 5 & 191 & 233 & 164 & 300 & 0.70 & 2 & 2 & 3600 & 19.42 & 0 & $6.83 \mathrm{E}-10$ & 21.1 & -8 \\
\hline 6 & 311 & -450 & 7 & 100 & 0.70 & 2 & 2 & 3600 & 23.67 & 0 & $5.07 \mathrm{E}-10$ & 20.5 & 16 \\
\hline 7 & 560 & -547 & -294 & 10 & 0.70 & 2 & 2 & 3600 & 27.49 & 0 & $6.91 \mathrm{E}-10$ & 19.1 & 44 \\
\hline 8 & 706 & -551 & -502 & 10 & 0.70 & 2 & 2 & 3600 & 34.74 & 0 & $2.04 \mathrm{E}-09$ & 16.4 & 111 \\
\hline 9 & 724 & -557 & -457 & 10 & 0.70 & 2 & 2 & 3600 & 36.96 & 0 & $3.70 \mathrm{E}-09$ & 15.8 & 134 \\
\hline
\end{tabular}

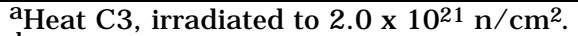

${ }^{b}$ Represents values in the effluent.

Conductivity was 0.07 and $0.3-0.45 \mu \mathrm{S} / \mathrm{cm}$ in feedwater and effluent, respectively. Feedwater $\mathrm{pH}$ at room

temperature was 6.5 .

A photomicrograph of the fracture surface of both halves of the specimen is shown in Fig. 30. The final crack length was determined from the photograph of both halves of the fractured specimen. Several unbroken ligaments can be seen extending back from the final crack front. Because of these unbroken ligaments the crack lengths were determined from an average of 16 evenly spaced measurements. A total 17 measurements were made, the two near-surface measurements were averaged, and the resultant value was averaged with the remaining 15 measurements. The actual crack extension was $\approx 40 \%$ greater than the value 


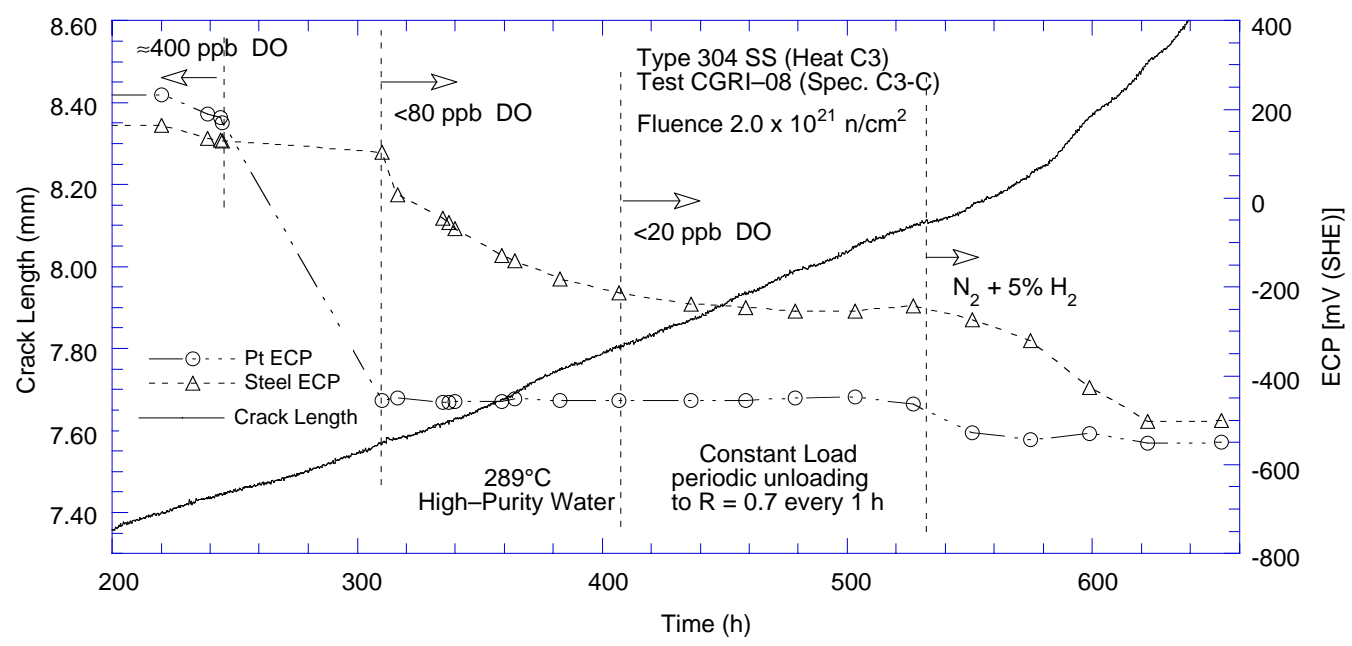

Figure 29. Change in crack length and ECP of Pt and SS electrodes for Specimen C3-C after the dissolved oxygen level in the feedwater was decreased from $\approx 300$ to $10 \mathrm{ppb}$

determined from the DC potential measurements. This difference is larger than is typically observed in most of our CGR tests, and is most likely due to the presence of the unbroken ligaments. Crack extensions estimated from the DC potential method were scaled proportionately. The values given in Table 4 are the corrected values of $K_{\max }$ and growth rate.

The changes in the (corrected) crack length and $\mathrm{K}_{\max }$ with time during various test periods are shown in Figs. 31a-d. For this specimen, significant environmental enhancement occurred after $\approx 100 \mathrm{~h}$ (Fig. $31 \mathrm{~b}$ ) during continuous cycling at $\mathrm{R}=0.7$ when the rise time was changed from $30 \mathrm{~s}$ to $300 \mathrm{~s}$. For the new loading condition, although the predicted CGR in air decreased by a factor of $\approx 10$, the rate in water did not change.

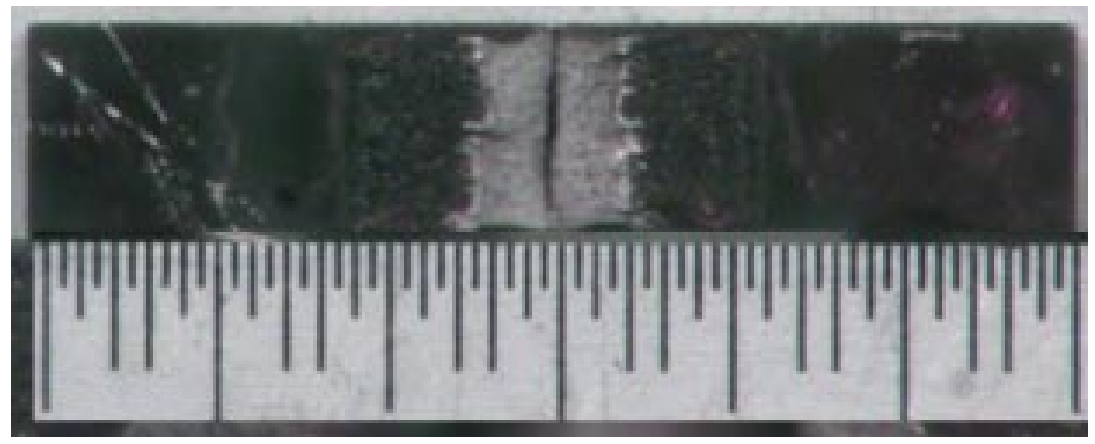

Figure 30. Photomicrographs of the fracture surface of Specimen C3-C

Figures 29 and $31 \mathrm{c}$ show that when the DO level was decreased from $\approx 300$ to $10 \mathrm{ppb}$, the steel ECP decreased from $\approx 240$ to $-255 \mathrm{mV}$ (SHE), but the CGR did not decrease. For a similar decrease in DO, the CGR of specimen C3-B, irradiated to $0.9 \times 10^{21} \mathrm{n} / \mathrm{cm}^{2}$, decreased by more than an order of magnitude. For specimen C3-C, the CGR actually increased at $\approx 570 \mathrm{~h}$ when the cover gas was changed from pure nitrogen to nitrogen plus $5 \%$ hydrogen and the steel ECP decreased below $-500 \mathrm{mV}$ (Fig. 31d). However, during the whole time at low ECP, the specimen $\mathrm{K} /$ size criteria were exceeded. Thus the apparent absence of a beneficial effect of reduced DO content on growth rates thus may be a test artifact. 


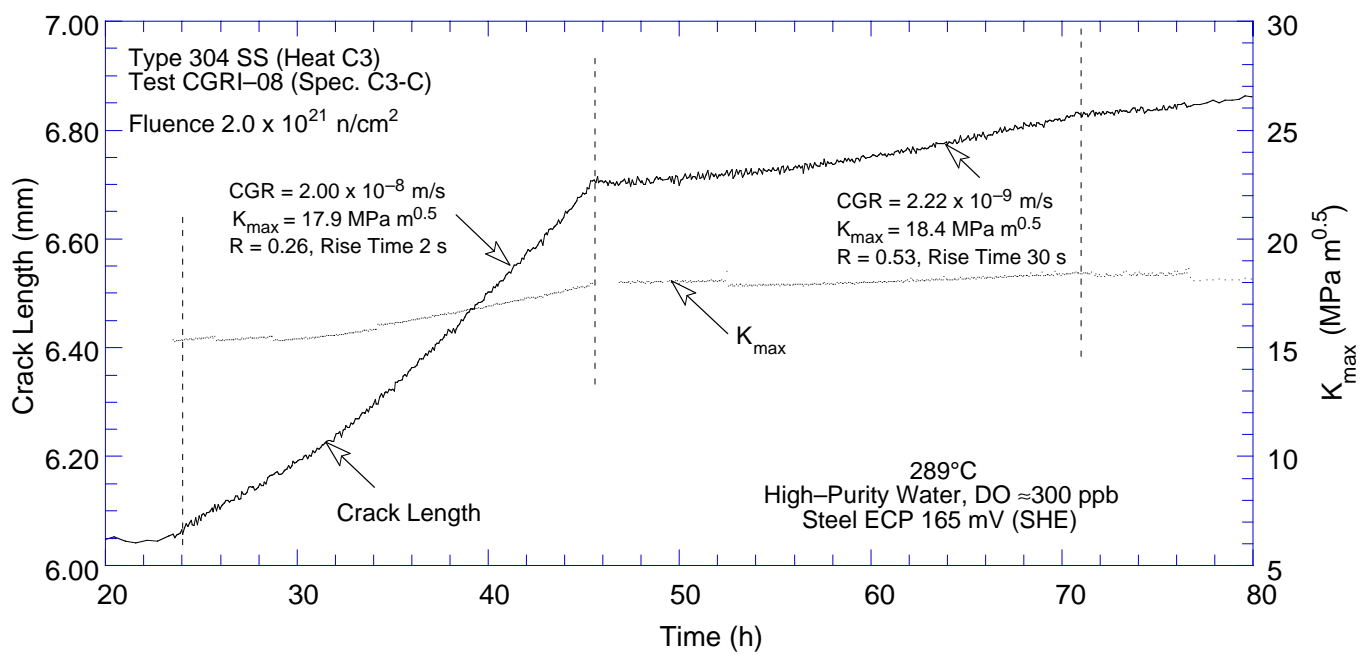

(a)

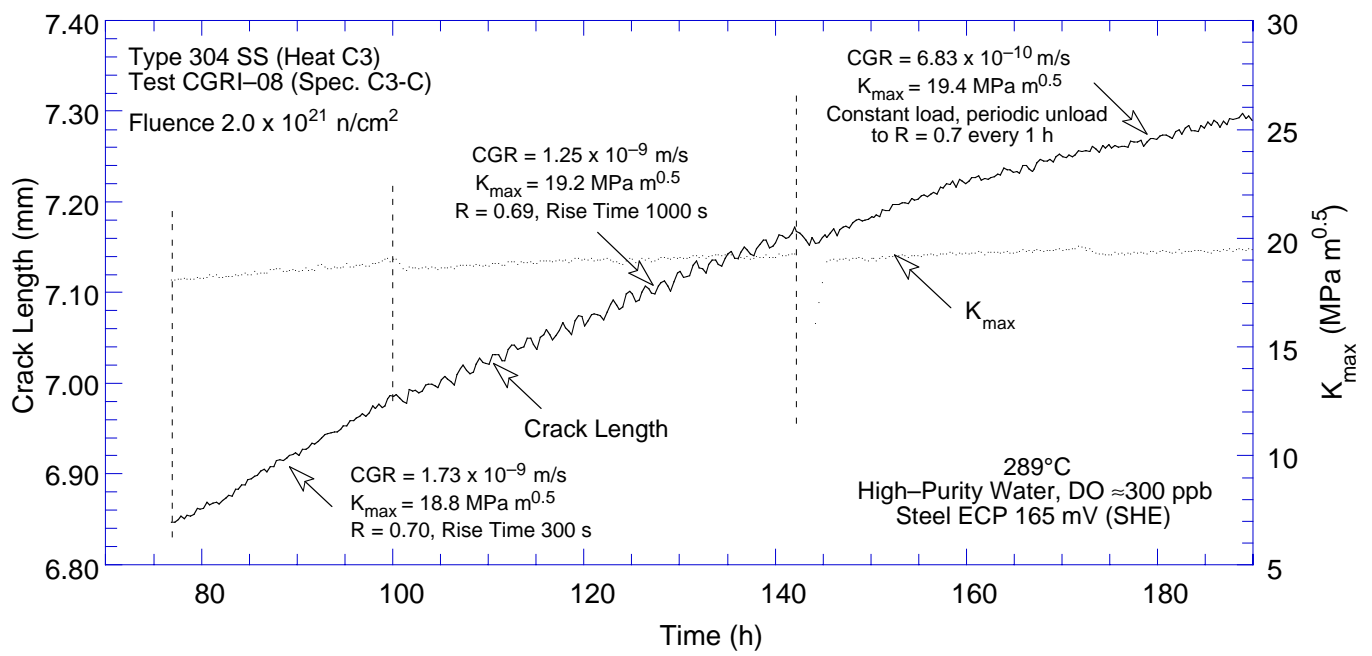

(b)

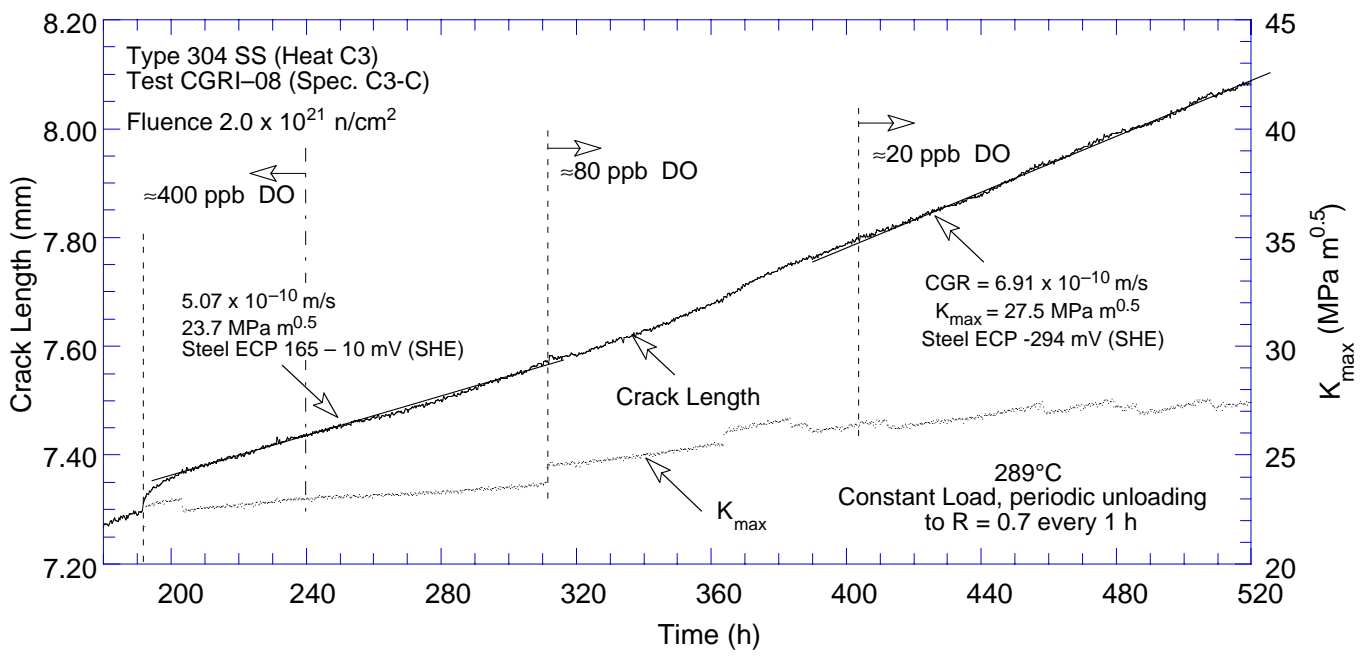

(c)

Figure 31. Crack-length-vs.-time plots for irradiated Type 304 SS (Heat C3) in high-purity water at $289^{\circ} \mathrm{C}$ during test periods (a) $1-2$, (b) $3-5$, (c) $6-7$, and (d) $7-8$ 


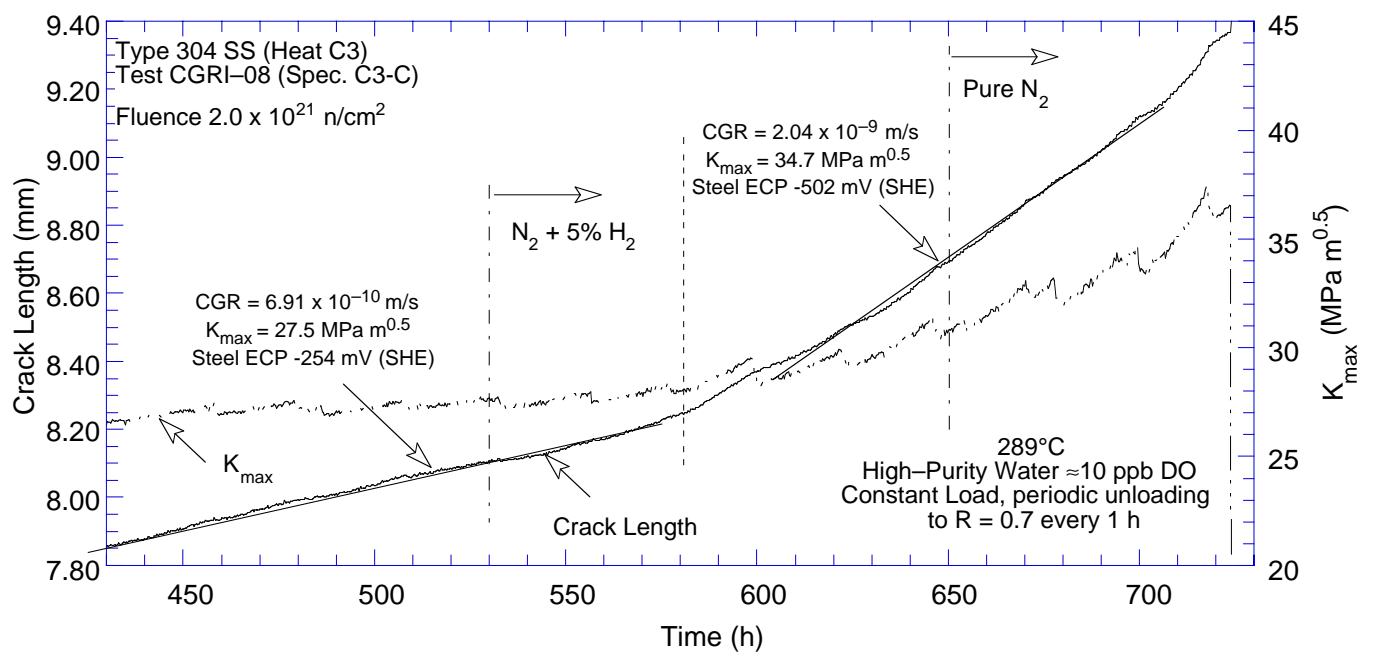

(d)

Figure 31. (Cont'd.)

\subsubsection{Specimen C16-B Irradiated to $2.0 \times 10^{21} \mathrm{n} / \mathrm{cm}^{2}$}

The environmental and loading conditions, experimental CGRs, allowed $\mathrm{K}_{\max }$ from $\mathrm{K} /$ size criterion in Eq. 13, and the deviation of applied $\mathrm{K}_{\max }$ from the allowed value are given in Table 5. Allowed $\mathrm{K}_{\max }$ was determined using effective yield stress in Eq. 13. Precracking was initiated at $\mathrm{R}=0.3$ and $\mathrm{K}_{\max }=14 \mathrm{MPa} \mathrm{m}^{1 / 2}$. After $\approx 0.4 \mathrm{~mm}$ advance, $\mathrm{R}$ was increased incrementally to 0.7 , and rise time increased to $30 \mathrm{~s}$. The maximum stress intensity factor $\mathrm{K}_{\max }$ was maintained approximately constant by periodic load shedding. After $\approx 265 \mathrm{~h}$, the DO level in the feedwater was decreased from $\approx 250 \mathrm{ppb}$ to $<30 \mathrm{ppb}$ by sparging the feedwater tank initially with pure nitrogen and then with nitrogen plus $5 \%$ hydrogen gas mixture. After $780 \mathrm{~h}$,

Table 5. Crack growth results for Specimen C16-B of Type $316 \mathrm{SS}^{\mathrm{a}}$ in high-purity water at $289^{\circ} \mathrm{C}$

\begin{tabular}{|c|c|c|c|c|c|c|c|c|c|c|c|c|c|}
\hline Test & $\begin{array}{l}\text { Test } \\
\text { Time, }\end{array}$ & $\begin{array}{r}\mathrm{EC} \\
\mathrm{mV}\end{array}$ & $\mathrm{HE})$ & $\begin{array}{c}\mathrm{O}_{2} \\
\text { Conc., }{ }^{\mathrm{b}}\end{array}$ & Load & $\begin{array}{l}\text { Rise } \\
\text { Time, }\end{array}$ & $\begin{array}{l}\text { Down } \\
\text { Time, }\end{array}$ & $\begin{array}{l}\text { Hold } \\
\text { Time, }\end{array}$ & $\mathrm{K}_{\max }$ & $\Delta \mathrm{K}$ & $\begin{array}{l}\text { Growth } \\
\text { Rate, }\end{array}$ & $\begin{array}{c}\mathrm{K}_{\max } \text { from } \\
\text { Eq. } 13\end{array}$ & $\begin{array}{l}\text { Deviation } \\
\text { in } \mathrm{K}_{\max }\end{array}$ \\
\hline Period & $\mathrm{h}$ & $\mathrm{Pt}$ & Steel & $\mathrm{ppb}$ & Ratio & & & & $\mathrm{MPa} \cdot \mathrm{m}^{1 / 2}$ & $\mathrm{MPa} \cdot \mathrm{m}^{1 / 2}$ & $\mathrm{~m} / \mathrm{s}$ & $\mathrm{MPa} \mathrm{m}^{1 / 2}$ & \\
\hline Pre a & 6 & - & - & 250 & 0.32 & 1 & 1 & 0 & 14.3 & 9.8 & $1.75 \mathrm{E}-08$ & & \\
\hline Pre b & 30 & 232 & 144 & 250 & 0.30 & 2 & 2 & 0 & 14.0 & 9.8 & 7.54E-09 & & \\
\hline Pre c & 52 & 227 & 144 & 250 & 0.31 & 2 & 2 & 0 & 14.2 & 9.8 & $8.94 \mathrm{E}-09$ & & \\
\hline 1 & 94 & 224 & 148 & 250 & 0.56 & 12 & 2 & 0 & 14.6 & 6.4 & $4.94 \mathrm{E}-10$ & 22.2 & -35 \\
\hline 2 & 132 & 226 & 147 & 250 & 0.73 & 30 & 2 & 0 & 14.8 & 4.0 & $8.65 \mathrm{E}-10$ & 22.0 & -33 \\
\hline 3 & 173 & 228 & 151 & 250 & 0.71 & 300 & 2 & 0 & 15.0 & 4.4 & $8.16 \mathrm{E}-10$ & 21.8 & -31 \\
\hline 4 & 198 & 224 & 153 & 250 & 0.70 & 1000 & 12 & 0 & 15.0 & 4.5 & $7.33 \mathrm{E}-10$ & 21.7 & -31 \\
\hline 5 & 265 & 162 & 117 & 250 & 0.70 & 12 & 12 & 3600 & 15.2 & 0 & $4.62 \mathrm{E}-10$ & 21.4 & -29 \\
\hline 6 & 410 & -547 & -298 & $<30$ & 0.70 & 12 & 12 & 3600 & 15.2 & 0 & $1.90 \mathrm{E}-11$ & 21.3 & -28 \\
\hline 7 & 504 & -562 & -410 & $<30$ & 0.70 & 1000 & 12 & 0 & 15.2 & 4.54 & $2.76 \mathrm{E}-11$ & 21.3 & -29 \\
\hline 8 & 527 & -560 & -449 & $<30$ & 0.73 & 30 & 2 & 0 & 15.2 & 4.10 & $6.07 \mathrm{E}-11$ & 21.3 & -29 \\
\hline 9 & 552 & -557 & -502 & $<30$ & 0.70 & 30 & 2 & 0 & 17.3 & 5.18 & $2.51 \mathrm{E}-10$ & 21.2 & -18 \\
\hline 10 & 600 & -554 & -545 & $<30$ & 0.69 & 1000 & 12 & 0 & 17.2 & 5.34 & $3.59 \mathrm{E}-11$ & 21.2 & -19 \\
\hline 11 & 672 & -557 & -554 & $<30$ & 0.70 & 12 & 12 & 3600 & 17.3 & 0 & $1.73 \mathrm{E}-11$ & 21.1 & -18 \\
\hline 12 & 792 & -438 & -597 & $<30$ & 0.70 & 12 & 12 & 3600 & 19.7 & 0 & $4.11 \mathrm{E}-11$ & 21.1 & -7 \\
\hline 13 & 866 & 219 & 139 & 250 & 0.70 & 12 & 12 & 3600 & 19.6 & 0 & $7.14 \mathrm{E}-10$ & 21.0 & -7 \\
\hline 14 & 871 & 224 & 148 & 250 & 0.70 & 12 & 12 & 3600 & 21.9 & 0 & $1.10 \mathrm{E}-09$ & 20.9 & 5 \\
\hline 15 & 888 & 224 & 148 & 250 & $1.00^{c}$ & 0 & 0 & - & 21.9 & - & $5.27 \mathrm{E}-10$ & 20.9 & 5 \\
\hline
\end{tabular}




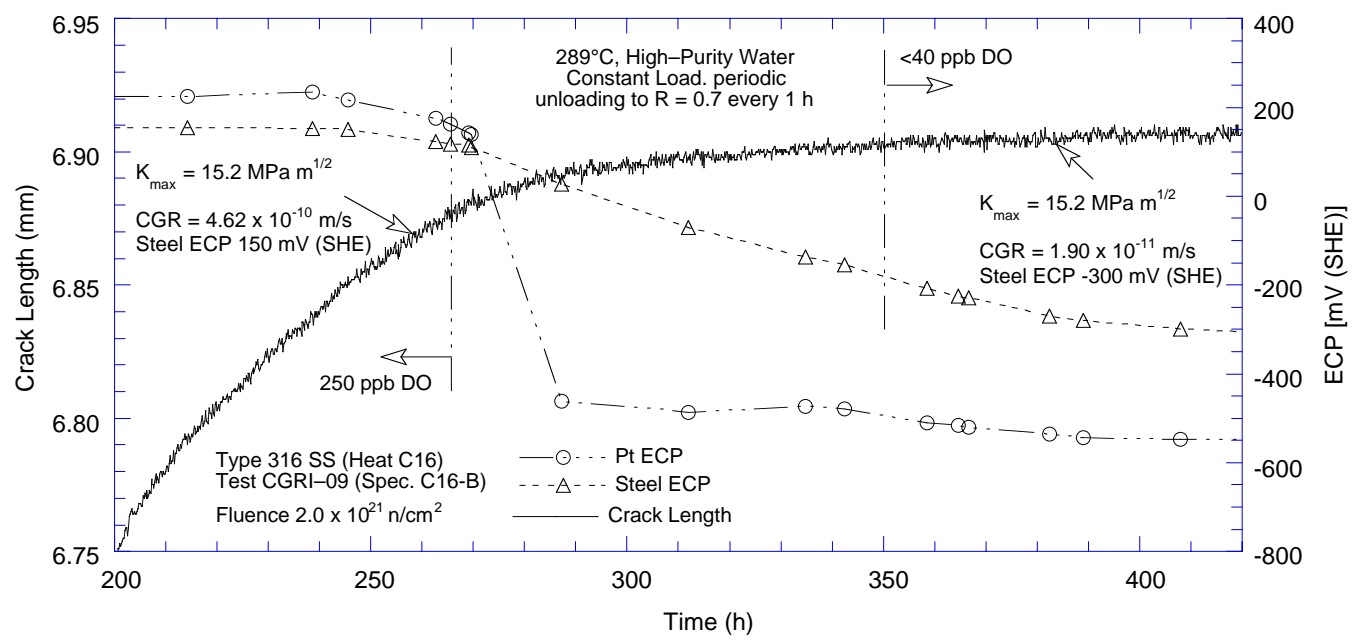

(a)

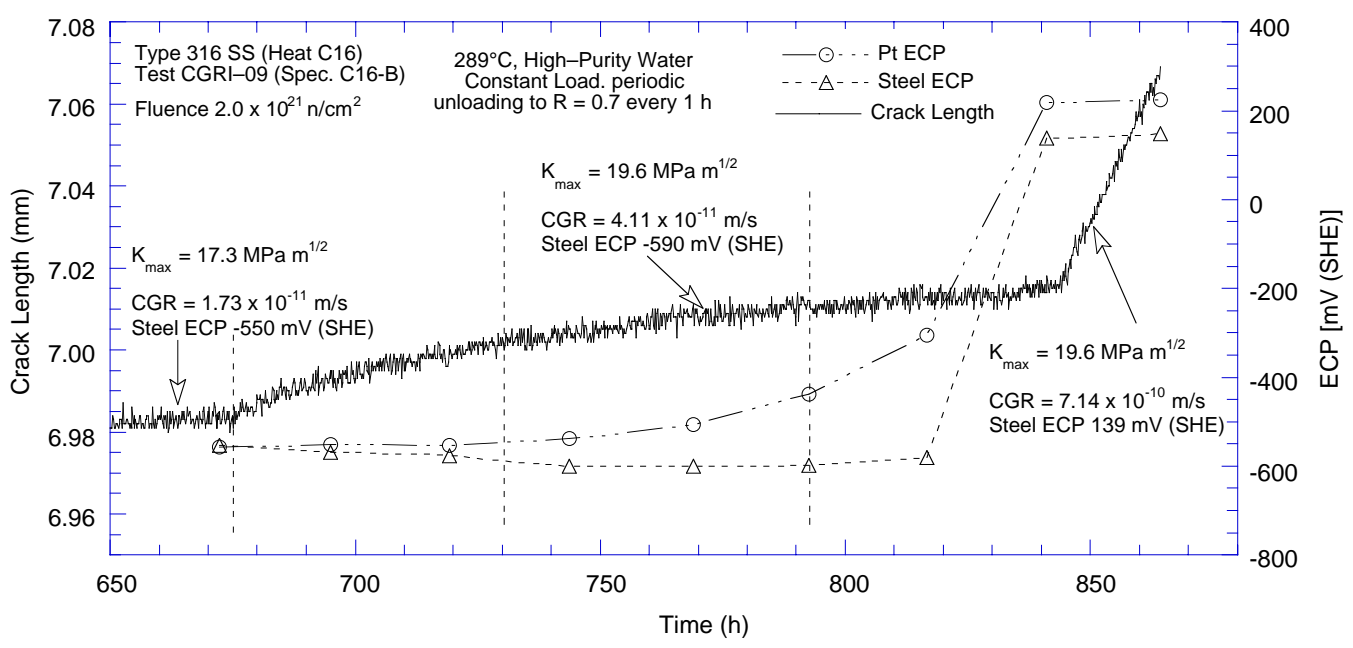

(b)

Figure 32. Change in crack length and ECP of Pt and SS electrodes when the DO level in feedwater was (a) decreased from $\approx 300$ to $<40 \mathrm{ppb}$ and (b) increased from $<40$ to $\approx 300 \mathrm{ppb}$.

the DO level was increased back to $\approx 250 \mathrm{ppb}$ by sparging the feedwater with nitrogen plus $1 \%$ oxygen. Change in crack length and ECP of Pt and SS electrodes during the transient periods are shown in Fig. 32. In both cases, it took more than $100 \mathrm{~h}$ for the changes to occur.

A photomicrograph of the fracture surface of both halves of the specimen is shown in Fig. 33. The final crack length, determined from the photograph, showed very good agreement with the value estimated from the DC potential measurement. Also, the results in Table 5 indicate that for specimen $\mathrm{C} 16-\mathrm{B}$, loading conditions for all test periods satisfied the $\mathrm{K} /$ size criterion of Eq. 13.

The changes in corrected crack length and $\mathrm{K}_{\max }$ with time during various test periods are shown in Figs. 34a-g. For this specimen, environmental enhancement occurred at $\approx 150 \mathrm{~h}$ (Fig. 34b) during continuous cycling at $\mathrm{R}=0.7$ when the rise time was changed from $30 \mathrm{~s}$ to $300 \mathrm{~s}$. For the new loading condition, although the predicted CGR in air decreased by a factor of $\approx 10$, the rate in water did not change. 


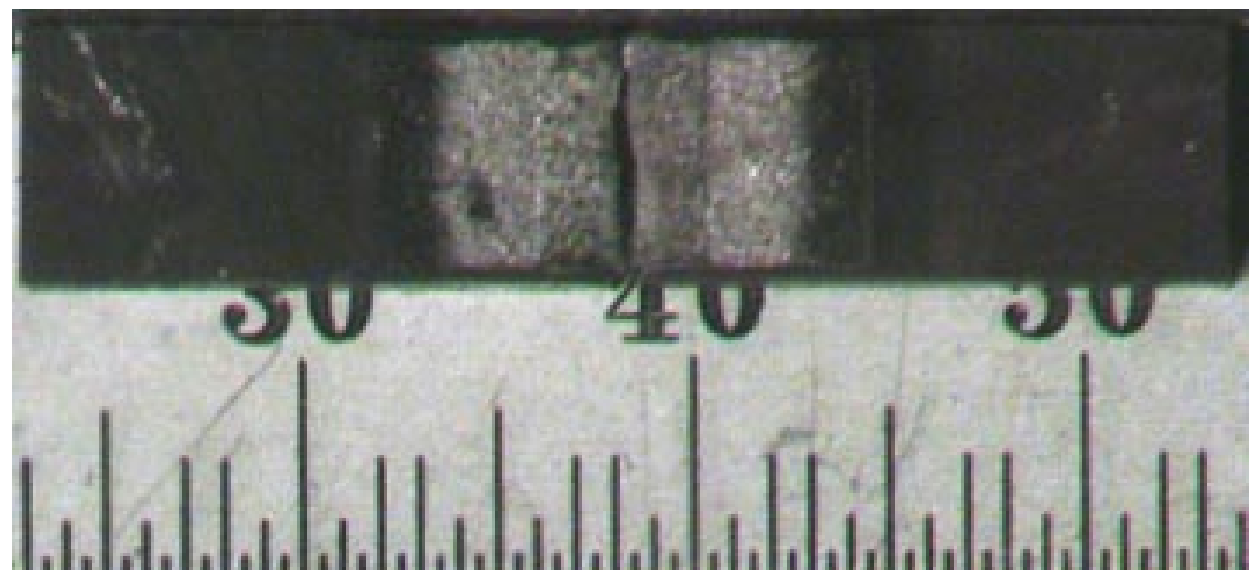

Figure 33. Photomicrographs of the fracture surface of Specimen C16-B

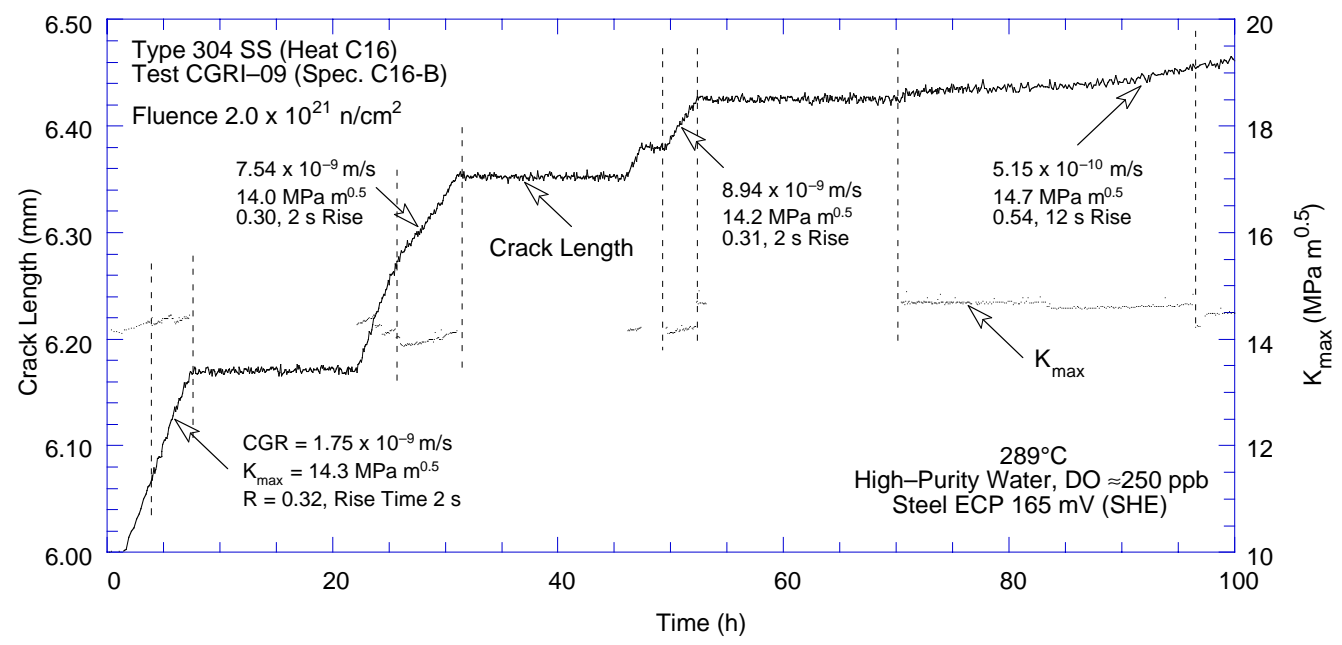

(a)

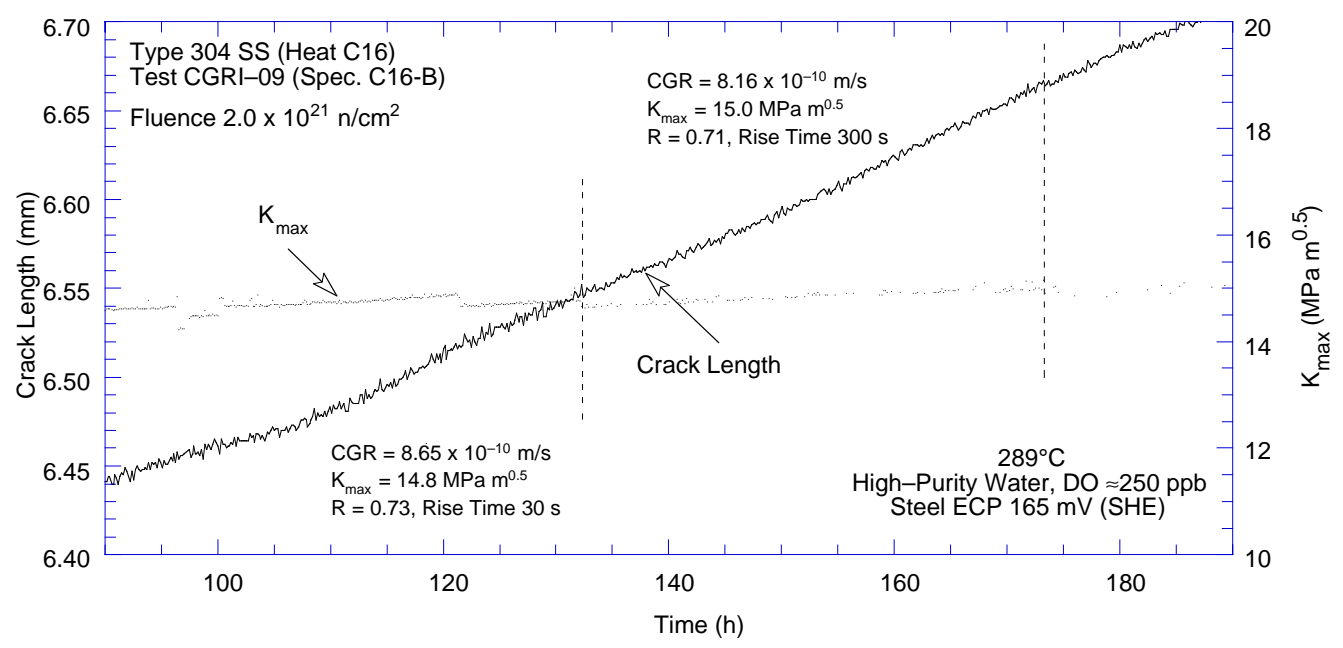

(b)

Figure 34. Crack-length-vs.-time plots for irradiated Type 316 SS (Heat C16) in high-purity water at $289^{\circ} \mathrm{C}$ during test periods (a) up to 1 , (b) $2-3$, (c) $4-5$, (d) $6-7$, (e) $8-10$, (f) $11-12$, and (g) $13-15$. 


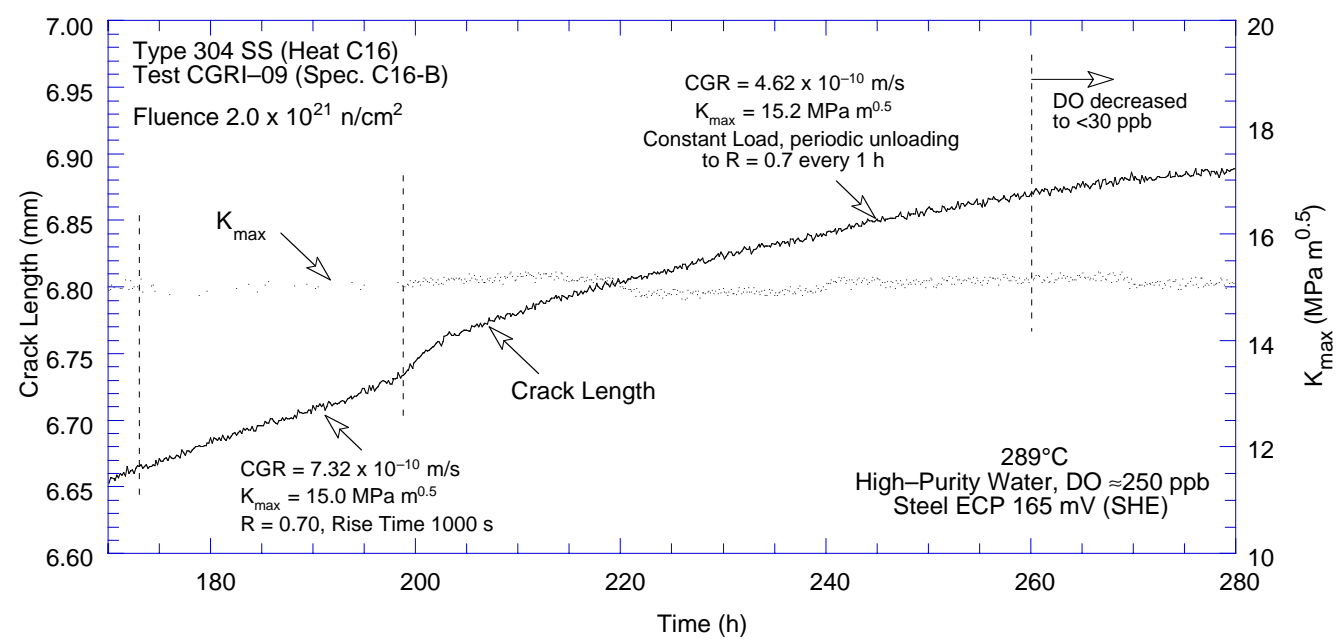

(c)

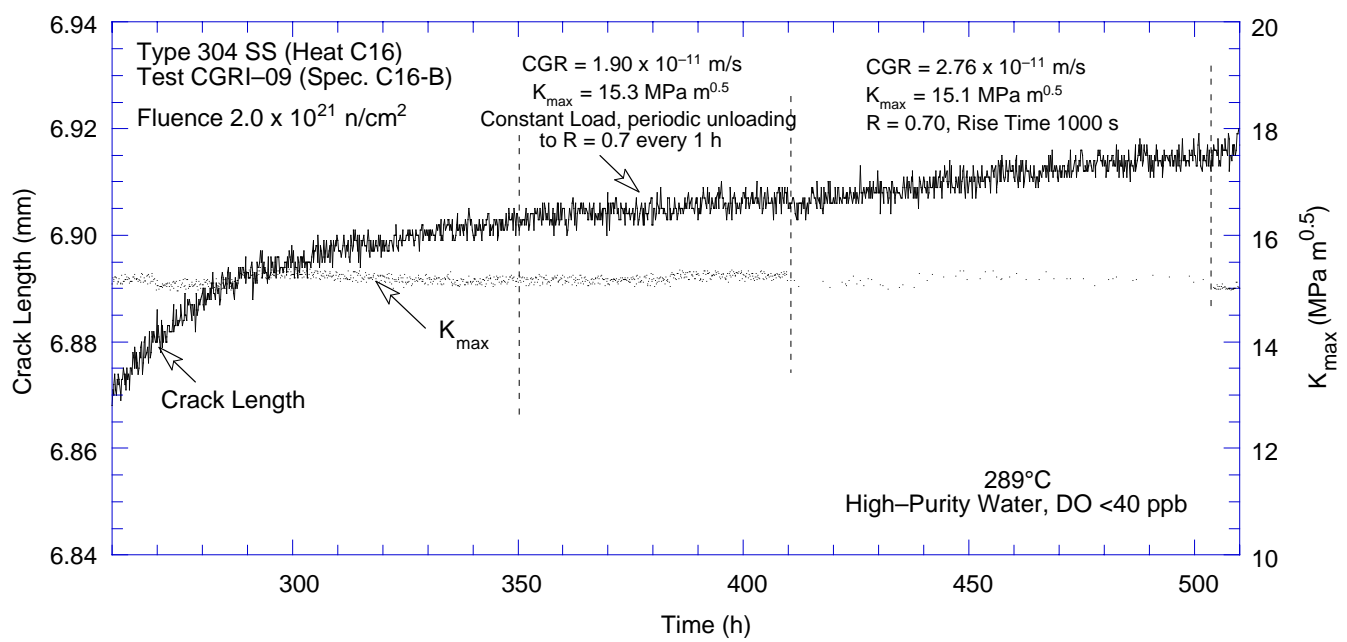

(d)

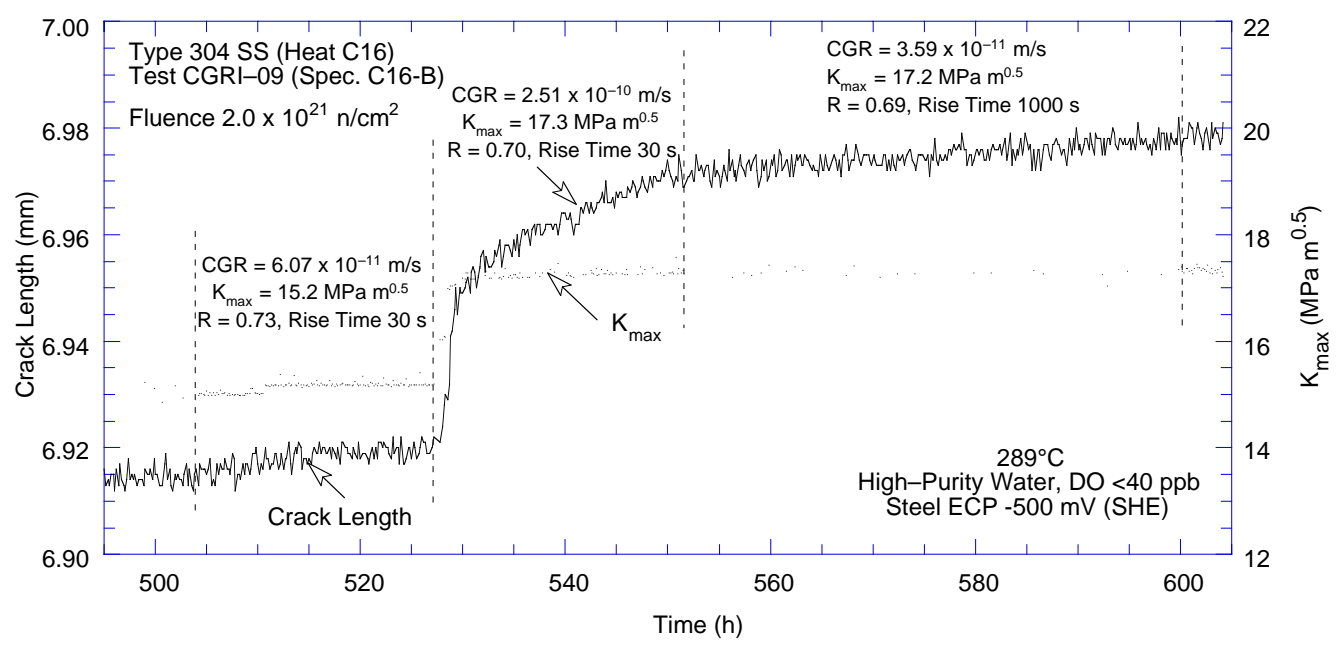

(e)

Figure 34. (Cont'd.) 


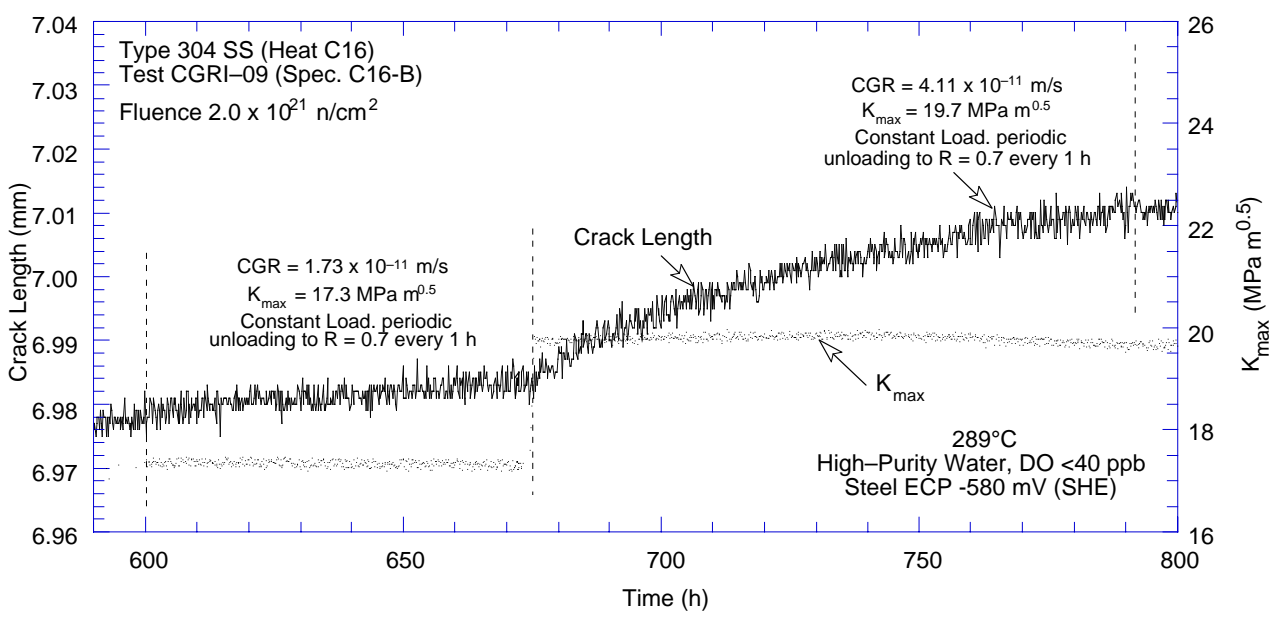

(f)

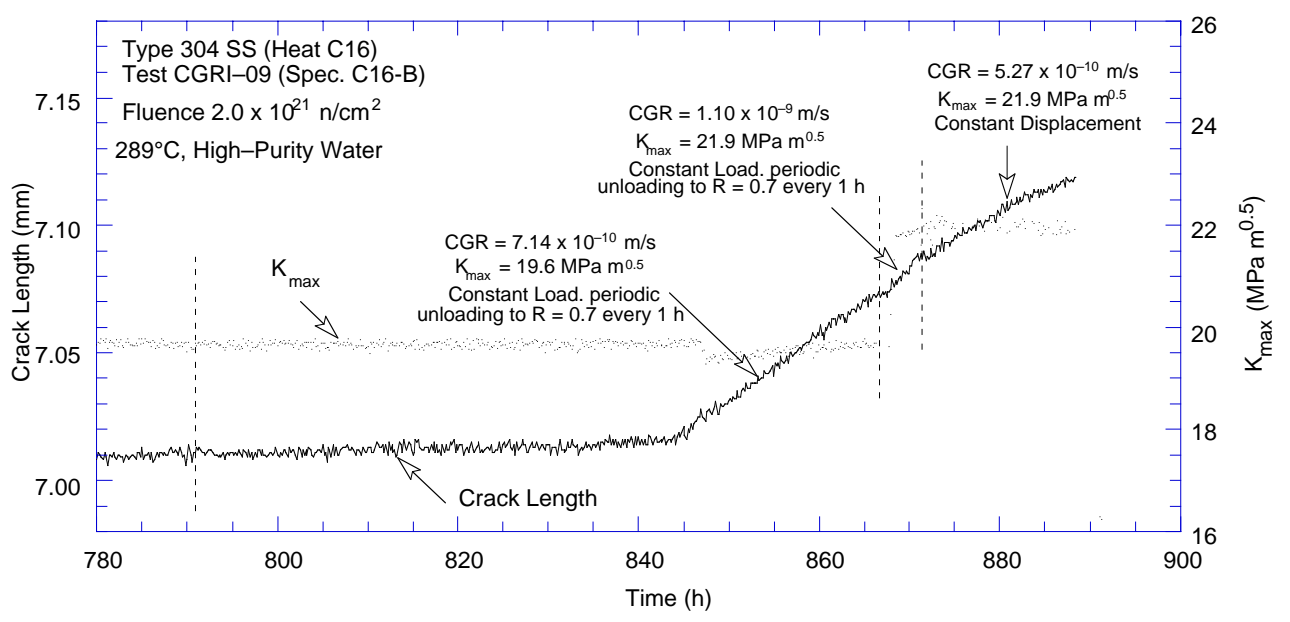

(g)

Figure 34. (Cont'd.)

For this test, a change in loading conditions from continuous cycling to nearly constant load (e.g., at $198 \mathrm{~h}$ ), or an increase in applied $\mathrm{K}_{\max }$ (e.g., at $527 \mathrm{~h}$ ), resulted in a transition period of somewhat high CGRs; the growth rates gradually decrease later with time. At $527 \mathrm{~h}$, the increase in $\mathrm{K}_{\max }$ was accomplished by three load increments over a relatively short period of $\approx 0.5 \mathrm{~h}$. It resulted in a crack advance of $\approx 0.03 \mathrm{~mm}$ (Fig. 34e). To avoid such crack advances, the increase in load at $675 \mathrm{~h}$ was achieved using a ramp loading with $2-\mathrm{h}$ rise time (Fig. 34f). The sudden increase in crack length was not observed with gradual increase in load.

In addition, the crack growth behavior with a decrease in DO differed distinctly from that when the DO level was increased (Fig. 32a and b). With decreasing DO, the CGRs decreased by a factor of about 25, but the change was relatively gradual, extending over $60 \mathrm{~h}$. With increasing DO, the growth rates increased abruptly from $4.11 \times 10^{-11}$ to $7.14 \times 10^{-10} \mathrm{~m} / \mathrm{s}$, a factor of 17 increase in CGRs. The ECPs of both the Pt and steel electrodes were above $100 \mathrm{mV}$ at the time of this increase in growth rate.

Irradiated to the same fluence level as Type 304 SS specimen C3-C, the Type 316 SS specimen C16-B clearly does show a benefit of reduced DO level on CGRs (Fig. 32a). The growth rates decreased by more than an order of magnitude when DO was decreased from 250 
to $<30 \mathrm{ppb}$. Additional data will be obtained to establish the effect of decreased DO level on the CGRs of irradiated austenitic SSs from testing samples from the Halden II irradiation.

\subsubsection{Specimen C3-A Irradiated to $0.3 \times 10^{21} \mathrm{n} / \mathrm{cm}^{2}$}

The environmental and loading conditions, experimental CGRs, allowed $\mathrm{K}_{\max }$ from $\mathrm{K} / \mathrm{size}$ criterion in Eq. 13, and the deviation of applied $K_{\max }$ from the allowed value are given in Table 6. For this specimen, because the ultimate-to-yield stress ratio was $>1.3$ (Table 2), effective flow stress instead of effective yield stress was used to determine the allowed $\mathrm{K}_{\max }$ from Eq. 13. The test was started in a high-DO environment $(\approx 300 \mathrm{ppb} \mathrm{DO}$ in effluent), and the water flow rate was $\approx 10 \mathrm{~mL} / \mathrm{min}$. The ECPs of Pt and SS electrodes in the effluent stream were monitored continuously. Precracking was carried out at $\mathrm{R}=0.3$ and $\mathrm{K}_{\max }=13-14 \mathrm{MPa}$ $\mathrm{m}^{1 / 2}$. After $\approx 0.3 \mathrm{~mm}$ crack advance, $\mathrm{R}$ was increased incrementally to 0.7 , and the waveform was changed from triangular to saw-tooth with rise times of $12-500 \mathrm{~s}$.

A photomicrograph of the fracture surface of both halves of the specimen is shown in Fig. 35. The final crack length, determined from the photograph, showed very good agreement with the value estimated from the DC potential measurement. Also, the results in Table 6 indicate that for specimen C3-A, loading conditions for all test periods, except 11 and 12 , satisfied the K/size criterion of Eq. 13.

The changes in crack length and $\mathrm{K}_{\max }$ with time during various test periods are shown in Figs. 36a-e. For this specimen, crack growth could not be maintained for loading conditions with high values of $R$ and relatively low $K_{\max }$. For example, at $K_{\max }=14 \mathrm{MPa} \mathrm{m}{ }^{1 / 2}$ increasing $\mathrm{R}$ from 0.3 to 0.5 essentially stopped crack growth (Fig. 36a). Changing $\mathrm{R}$ back to the earlier value did not restore crack growth; $\mathrm{K}_{\max }$ had to be increased to start crack growth. To promote environmentally enhanced crack growth, the rise time for the cyclic loading at $\mathrm{R}=0.3$ was increased from 0.5 to $300 \mathrm{~s}$ before increasing $\mathrm{R}$ (Fig. 36b). For $\mathrm{R}=0.7$, crack growth occurred only at $\mathrm{K}_{\max }$ greater than $17 \mathrm{MPa} \mathrm{m}^{1 / 2}$.

Table 6. Crack growth results for Specimen C3-A of Type $304 \mathrm{SS}^{\mathrm{a}}$ in high-purity water at $289^{\circ} \mathrm{C}$

\begin{tabular}{|c|c|c|c|c|c|c|c|c|c|c|c|c|c|}
\hline Test & $\begin{array}{l}\text { Test } \\
\text { Time, }\end{array}$ & $\begin{array}{r}\mathrm{E} \\
\mathrm{mV}\end{array}$ & b & $\begin{array}{c}\mathrm{O}_{2} \\
\text { Conc., }\end{array}$ & Load & $\begin{array}{l}\text { Rise } \\
\text { Time, }\end{array}$ & $\begin{array}{l}\text { Down } \\
\text { Time, }\end{array}$ & $\begin{array}{l}\text { Hold } \\
\text { Time, }\end{array}$ & $\mathrm{K}_{\max }$ & $\Delta \mathrm{K}$ & $\begin{array}{l}\text { Growth } \\
\text { Rate, }\end{array}$ & $\begin{array}{c}\mathrm{K}_{\max } \text { from } \\
\text { Eq. } 13\end{array}$ & $\begin{array}{l}\text { Deviation } \\
\text { in } \mathrm{K}_{\max } \text {, }\end{array}$ \\
\hline Period & $\mathrm{h}$ & $\mathrm{Pt}$ & Steel & $\mathrm{ppb}$ & Ratio & $\mathrm{s}$ & $\mathrm{s}$ & $\mathrm{s}$ & $\mathrm{MPa} \cdot \mathrm{m}^{1 / 2}$ & $\mathrm{MPa} \cdot \mathrm{m}^{1 / 2}$ & $\mathrm{~m} / \mathrm{s}$ & $\mathrm{MPa} \mathrm{m} \mathrm{m}^{1 / 2}$ & $\%$ \\
\hline Pre & 55 & 226 & 167 & 300 & 0.31 & 0.5 & 0.5 & 0 & 12.9 & 8.9 & $2.94 \mathrm{E}-09$ & 18.4 & -30 \\
\hline 1 & 165 & 212 & 166 & 300 & 0.30 & 0.5 & 0.5 & 0 & 14.0 & 9.8 & 8.37E-09 & 17.9 & -22 \\
\hline $2 a$ & 189 & 221 & 169 & 300 & 0.50 & 5 & 5 & 0 & 13.9 & 6.9 & negligible & 17.9 & -23 \\
\hline $2 \mathrm{~b}$ & 193 & 211 & 169 & 300 & 0.50 & 0.5 & 0.5 & 0 & 13.8 & 6.9 & negligible & 17.9 & -23 \\
\hline $2 \mathrm{c}$ & 214 & 209 & 161 & 300 & 0.30 & 0.5 & 0.5 & 0 & 13.9 & 9.7 & negligible & 17.9 & -23 \\
\hline $2 d$ & 219 & 211 & 163 & 300 & 0.30 & 0.5 & 0.5 & 0 & 15.0 & 10.5 & $1.48 \mathrm{E}-08$ & 17.7 & -15 \\
\hline 3 & 364 & 218 & 171 & 300 & 0.30 & 1 & 1 & 0 & 15.9 & 11.1 & $1.39 \mathrm{E}-08$ & 17.5 & -9 \\
\hline 4 & 380 & 218 & 171 & 300 & 0.30 & 30 & 4 & 0 & 16.0 & 11.2 & $1.33 \mathrm{E}-09$ & 17.4 & -8 \\
\hline 5 & 404 & 219 & 177 & 300 & 0.29 & 300 & 4 & 0 & 15.9 & 11.3 & $3.29 \mathrm{E}-10$ & 17.4 & -8 \\
\hline 6 & 479 & 204 & 173 & 300 & 0.48 & 300 & 4 & 0 & 15.7 & 8.2 & $4.75 \mathrm{E}-11$ & 17.4 & -10 \\
\hline 7 & 596 & 235 & 187 & 300 & 0.70 & 12 & 12 & 0 & 15.7 & 4.7 & negligible & 17.4 & -10 \\
\hline 8 & 670 & 228 & 188 & 300 & 0.70 & 12 & 12 & 0 & 17.6 & 5.3 & $6.23 \mathrm{E}-11$ & 17.3 & 2 \\
\hline 9 & 717 & 231 & 186 & 300 & 0.70 & 12 & 12 & 3600 & 17.8 & - & - & 17.3 & 3 \\
\hline 10 & 910 & 234 & 197 & 300 & 0.70 & 500 & 12 & 3600 & 17.9 & - & $8.65 \mathrm{E}-11$ & 17.2 & 4 \\
\hline 11 & 1080 & 232 & 200 & 300 & 0.70 & 500 & 12 & 3600 & 22.0 & - & $1.11 \mathrm{E}-10$ & 17.1 & 29 \\
\hline 12 & 1175 & 226 & 203 & 300 & 0.70 & 500 & 1 & 9500 & 22.3 & - & $1.28 \mathrm{E}-10$ & 17.0 & 31 \\
\hline
\end{tabular}




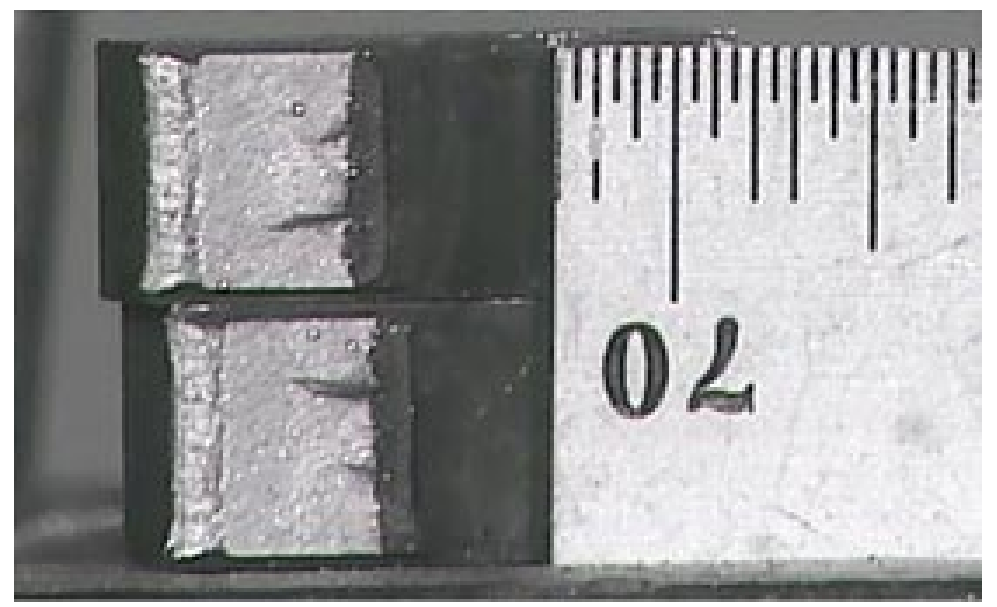

Figure 35. Photomicrographs of the fracture surface of Specimen C3-A

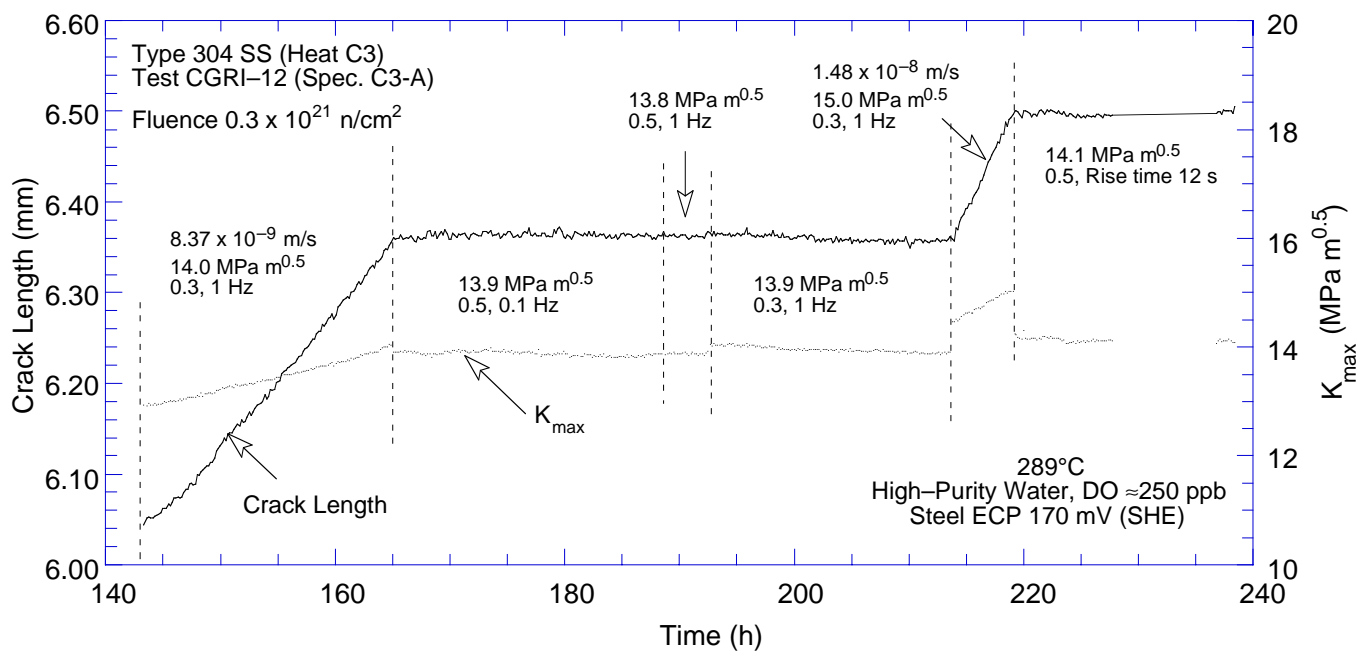

(a)

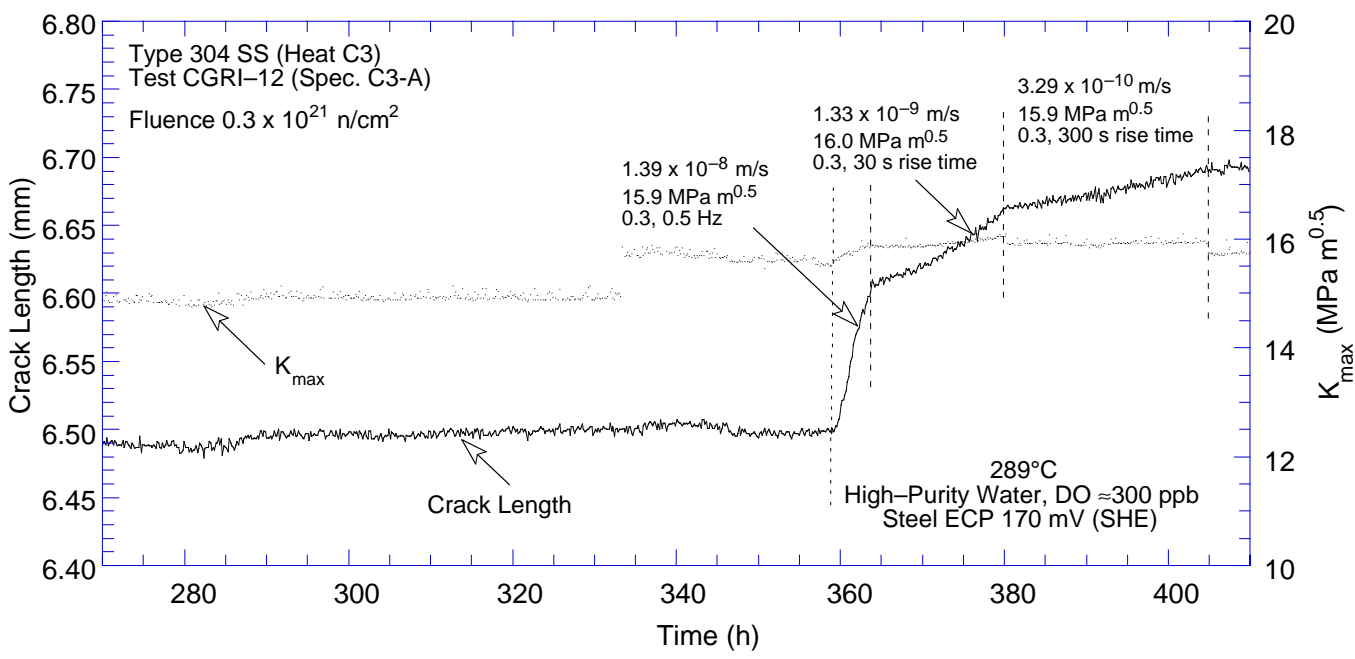

(b)

Figure 36. Crack-length-vs.-time plots for irradiated Type $316 \mathrm{SS}$ (Heat $\mathrm{C} 16$ ) in high-purity water at $289^{\circ} \mathrm{C}$ during test periods (a) $1-2$, (b) $3-5$, (c) $6-7$, (d) $8-10$, and (e) $11-12$. 


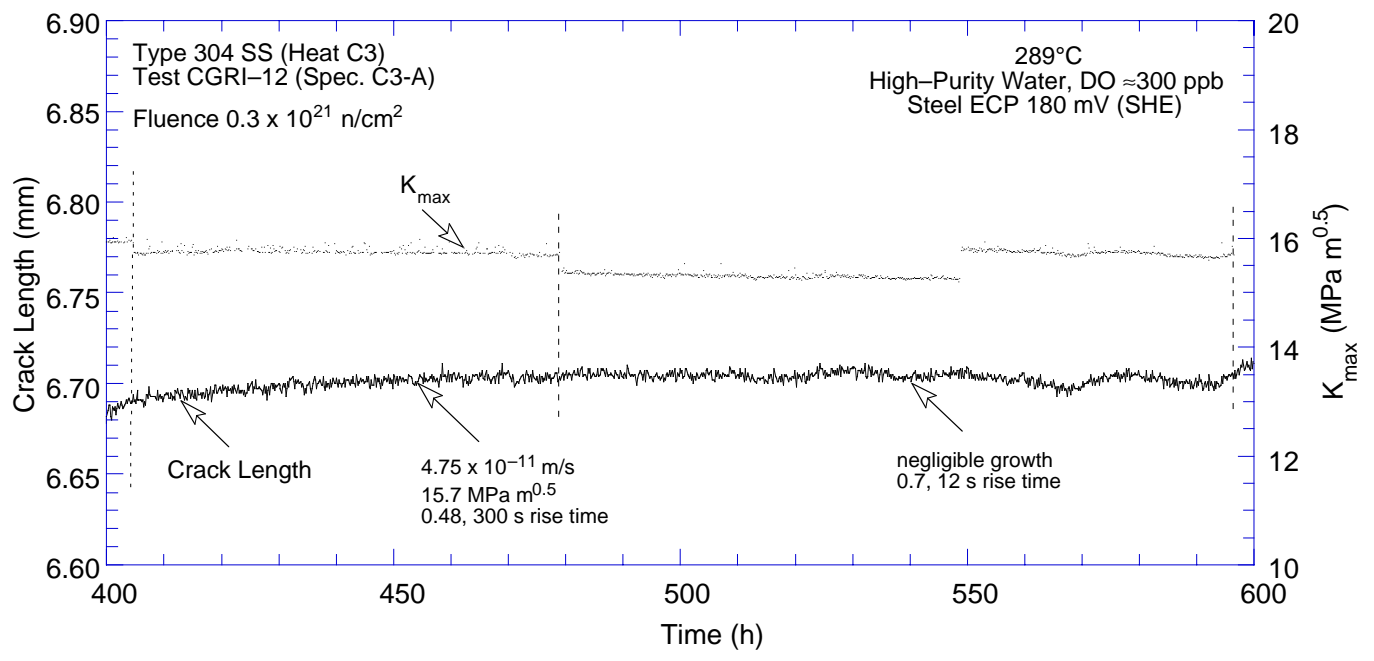

(c)

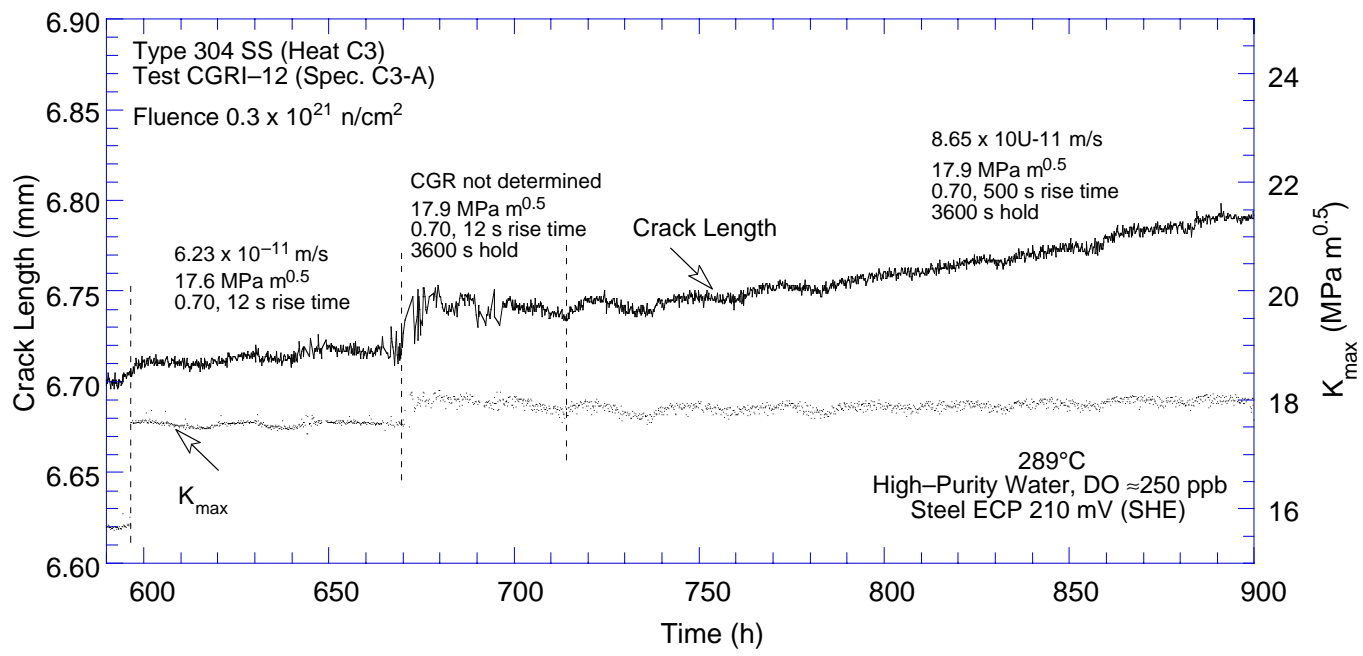

(d)

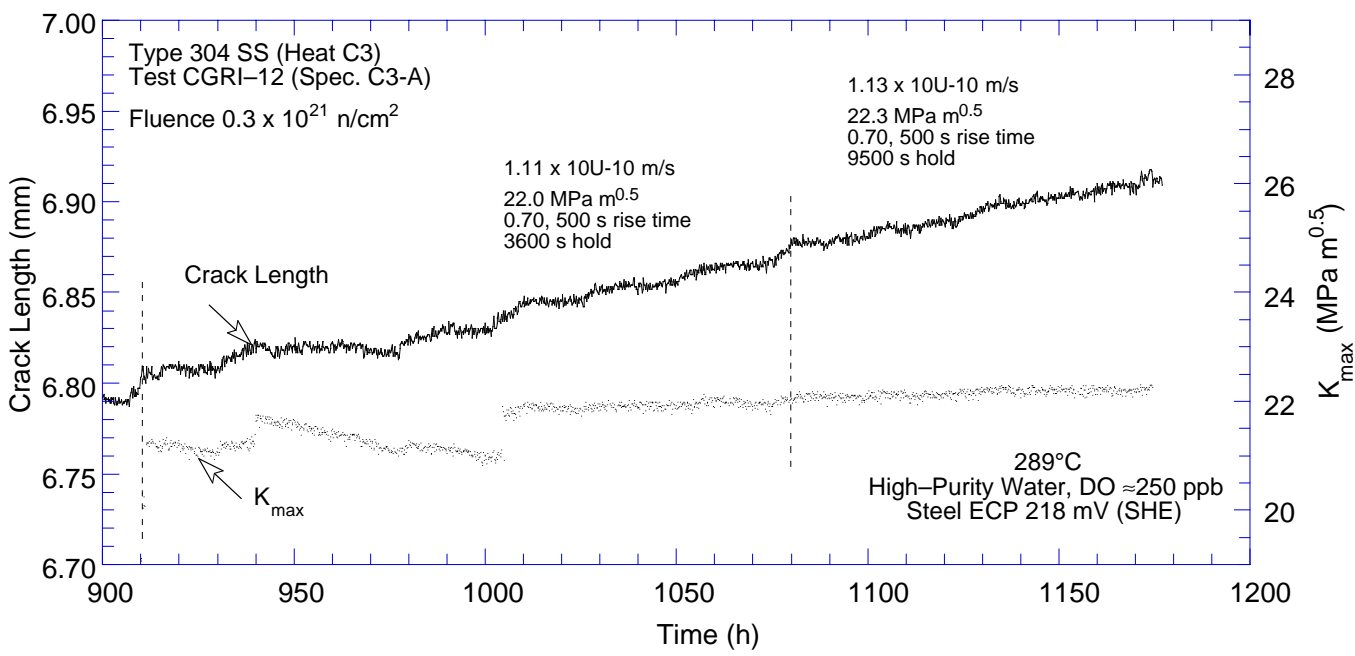

(e)

Figure 36. (Cont'd) 
Crack growth rates could not be measured during test period 9 because of significant variations in the autoclave temperature, which resulted in large fluctuations in the DC potential measurements (Fig. 36d). Also, during test period 11 (Fig. 36e), applied $\mathrm{K}_{\max }$ gradually decreased from the desired value of 22 to $20.5 \mathrm{MPa} \mathrm{m}^{1 / 2}$ over a $50-\mathrm{h}$ period because of faulty back-pressure regulator. Specimen C3-A irradiated to $0.3 \times 10^{21} \mathrm{n} / \mathrm{cm}^{2}$ showed very little environmental enhancement of CGRs both under continuous cycling and SCC conditions. There was no change in CGR when the hold time was increased from 3600 to $9500 \mathrm{~s}$ (Fig. 36e test period 11 and 12).

\subsubsection{CGRs of Irradiated Austenitic SSs under Continuous Cycling}

For continuous cyclic loading, the experimental CGRs for irradiated austenitic SSs in high- and low-DO environments and those predicted in air for the same loading conditions are plotted in Fig. 37. The curves represent the Shack/Kassner model for nonirradiated austenitic SSs in high-purity water with either 8 or $0.2 \mathrm{ppm}$ DO (Eqs. 18 and 19, respectively) and are included to provide a comparison with the irradiated CGR data. The CGRs in air $\dot{a}_{\text {air }}(\mathrm{m} / \mathrm{s})$ were determined from the correlations developed by James and Jones, ${ }^{36}$ e.g., Eqs. 15-17.

The results for SSs irradiated to 0.9 or $2.0 \times 10^{21} \mathrm{n} / \mathrm{cm}^{2}$ (1.35 or 3.0 dpa) indicate significant enhancement of the CGRs in high-DO water under cyclic loading with long rise times. The CGRs for Type $304 \mathrm{SS}$ irradiated to either 0.9 or $2.0 \times 10^{21} \mathrm{n} \cdot \mathrm{cm}^{-2}$, and Type 316 $\mathrm{SS}$ irradiated to $2.0 \times 10^{21} \mathrm{n} \cdot \mathrm{cm}^{-2}$ are comparable. For these irradiation conditions, the CGRs in water with $\approx 300 \mathrm{ppb}$ DO are slightly higher than the rates predicted by the Shack/Kassner model for nonirradiated austenitic SSs in high-purity water with 8 ppm DO (Fig. 37a).

Type $304 \mathrm{SS}$ irradiated to $0.3 \times 10^{21} \mathrm{n} / \mathrm{cm}^{2}(0.45 \mathrm{dpa})$ shows very little environmental enhancement of CGRs in high-DO water (open diamonds in Fig. 37a); the CGRs in water with $\approx 300 \mathrm{ppb}$ DO may be represented by the Shack/Kassner model for nonirradiated austenitic SSs in high-purity water with $0.2 \mathrm{ppm}$ DO.

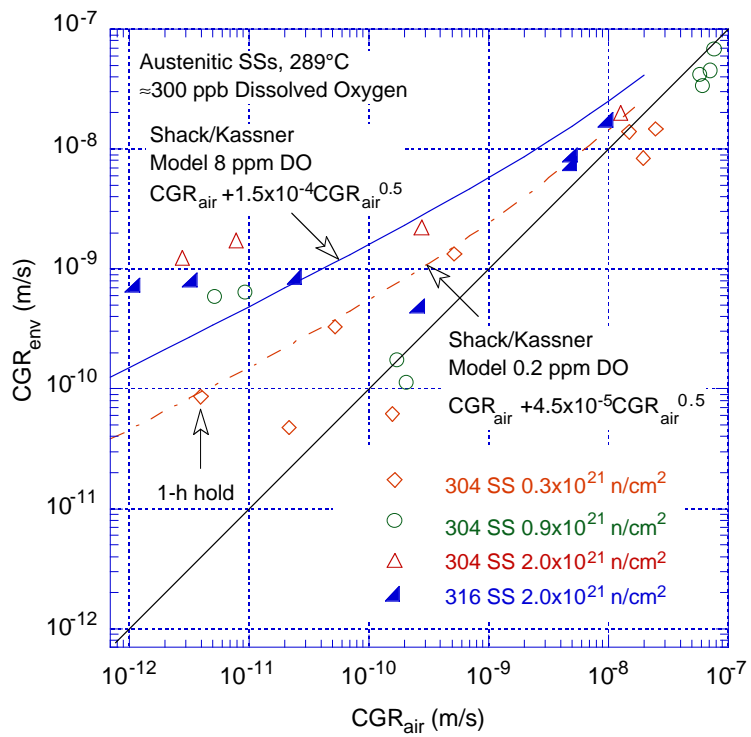

(a)

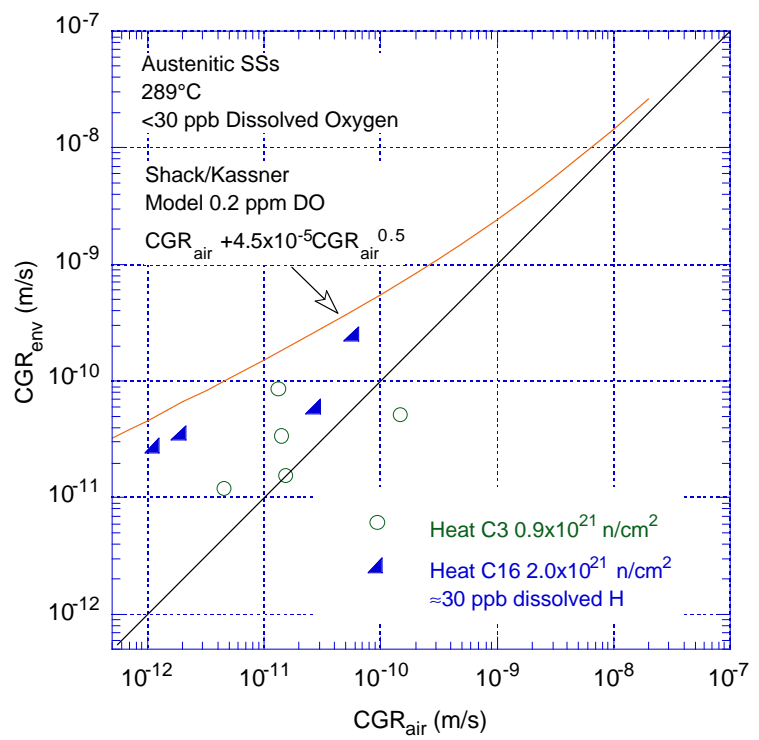

(b)

Figure 37. CGR data for irradiated austenitic SSs under continuous cycling at $289^{\circ} \mathrm{C}$ in high-purity water with $(\mathrm{a}) \approx 300 \mathrm{ppb}$ and $(\mathrm{b})<30 \mathrm{ppb}$ dissolved oxygen. 
For continuous cyclic loading, decreasing the DO level has a beneficial effect on CGRs, e.g., decreasing the DO from $\approx 300 \mathrm{ppb}$ DO to $<30 \mathrm{ppb}$ DO results in a factor of 25 decrease in the CGR. The growth rates are slightly lower for the irradiated steels in water with $<30 \mathrm{ppb}$ DO than for nonirradiated austenitic SSs in high-purity water with $0.2 \mathrm{ppm}$ DO (Fig. 37b). The CGR data in low-DO environment was not obtained for Type 304 SS specimen C3-C irradiated to $2 \times 10^{21} \mathrm{n} / \mathrm{cm}^{2}$. As discussed below, a benefit of reduced DO environment was not observed for this specimen under SCC conditions.

\subsubsection{CGRs of Irradiated Austenitic SSs under Cycling with Long Hold Periods}

For CGR tests with a trapezoidal waveform (i.e., constant load with periodic partial unloading), the experimental CGRs for irradiated SSs in high- and low-DO water are plotted in Fig. 38. In high-DO water, the CGRs obtained in the present study of Types 304 and 316 SS irradiated to either 0.9 or $2.0 \times 10^{21} \mathrm{n} / \mathrm{cm}^{2}$ are a factor of $\approx 5$ higher than the disposition curve for sensitized SSs in water with $8 \mathrm{ppm}$ DO given in NUREG-0313. ${ }^{37}$ The growth rates for the two steels at the same fluence level, as well as those for Type 304 SS irradiated to 0.9 and $2.0 \times 10^{21} \mathrm{n} / \mathrm{cm}^{2}$ fluence levels, are comparable. In high-DO water, the CGRs for Type 304 irradiated to $0.3 \times 10^{21} \mathrm{n} / \mathrm{cm}^{2}$ are below the disposition curve for sensitized SSs in water with 8 ppm DO given in NUREG-0313.

The results also indicate a benefit from a low-DO environment. For Heat C3 irradiated to $0.9 \times 10^{21} \mathrm{n} / \mathrm{cm}^{2}$ and Heat C16 irradiated to $2.0 \times 10^{21} \mathrm{n} / \mathrm{cm}^{2}$ (circles and open diamonds in Fig. 38), the CGRs decreased more than an order of magnitude when the DO level was decreased from $\approx 300$ to $<30 \mathrm{ppb}$.

No benefit of low-DO environment was observed for Heat C3 irradiated to $2.0 \mathrm{x}$ $10^{21} \mathrm{n} / \mathrm{cm}^{2}$ (open and closed triangles in Fig. 38). However, the applied $\mathrm{K}_{\max }$ for the test period in low-DO water was $44 \%$ greater than the allowable value based on the $\mathrm{K} /$ size criterion in Eq. 13. Additional data will be obtained on Type 316 SS Heat C21 irradiated to 0.3, 0.9, and $2.0 \times 10^{21} \mathrm{n} / \mathrm{cm}^{2}$, to better establish the effect of decreased DO level on the CGRs of irradiated austenitic SSs.

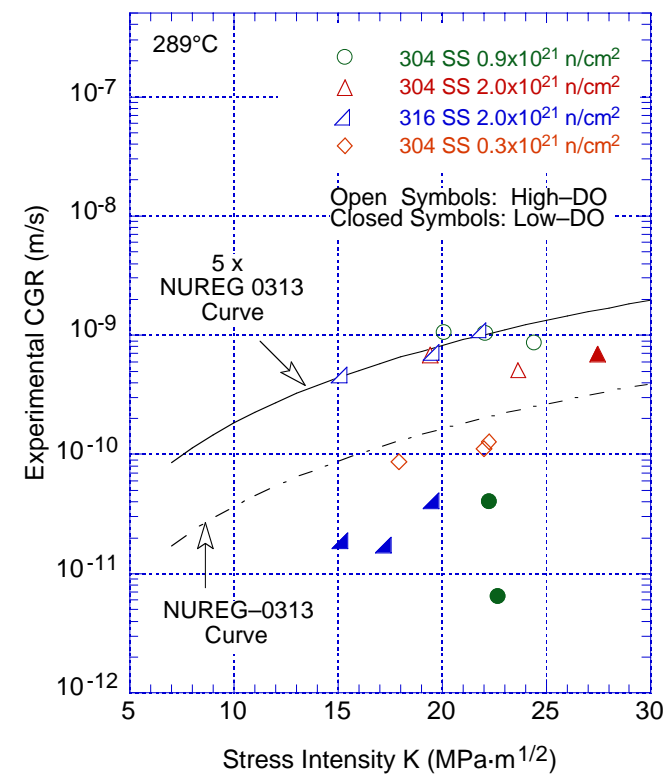

Figure 38.

CGR data under constant load with periodic partial unloads for irradiated austenitic SSs in high-purity water at $289^{\circ} \mathrm{C}$ 


\section{Summary}

Fracture toughness J-R curve tests have been conducted on four heats of Type 304 SS that were irradiated to fluence levels of $\approx 0.3,0.9$, and $2.0 \times 10^{21} \mathrm{n} / \mathrm{cm}^{2}(\mathrm{E}>1 \mathrm{MeV})(\approx 0.45$, $1.35,3.00 \mathrm{dpa}$ ) at $\approx 288^{\circ} \mathrm{C}$ in a helium environment in the Halden boiling heavy water reactor. The tests were performed on 1/4-T compact tension specimens in air at $288^{\circ} \mathrm{C}$; crack extensions were determined by both DC potential and elastic unloading compliance techniques.

Neutron irradiation at $288^{\circ} \mathrm{C}$ to $2.0 \times 10^{21} \mathrm{n} / \mathrm{cm}^{2}$ ( $\left.\mathrm{E}>1 \mathrm{MeV}\right)(3.0 \mathrm{dpa})$ decreased the fracture toughness of all of the steels. For these materials, minor differences in the chemical composition of the steels, e.g., differences in nickel content for Heats C16 and C19 or silicon content for heats L2 and L20, have little or no effect on the fracture toughness of irradiated steels.

In general, fracture toughness of the commercial Heats C16 and C19 is superior to that of the laboratory Heats L2O and L2. These differences arise primarily from differences in toughness of the nonirradiated steels, i.e., the fracture toughness of the laboratory heats is significantly lower than that of the commercial heats. The fracture toughness $\mathrm{J}-\mathrm{R}$ curves for irradiated Types 304 and 316 SS are comparable. The data from commercial heats fall within the scatter band for the data obtained at higher temperatures. For Heat C19 of Type 304 SS irradiated to $0.3,0.9$, and $2.0 \times 10^{21} \mathrm{n} / \mathrm{cm}^{2}$, the $\mathrm{J}_{\mathrm{Ic}}$ values are 507,313 , and $188 \mathrm{~kJ} / \mathrm{m}^{2}$, respectively.

Crack growth tests have been performed in simulated BWR environments at $\approx 289^{\circ} \mathrm{C}$ on Type 304 SS (Heat C3) irradiated to $0.3,0.9$, and $2.0 \times 10^{21} \mathrm{n} / \mathrm{cm}^{2}$ and Type 316 SS (Heat C16) irradiated to $2.0 \times 10^{21} \mathrm{n} / \mathrm{cm}^{2}$ at $\approx 288^{\circ} \mathrm{C}$ in a helium environment. The tests were conducted under cyclic loading with a slow/fast sawtooth waveform and long rise times or a trapezoidal waveform. The latter essentially represents constant load with periodic partial unloads.

The results for the steels irradiated to either 0.9 or $2.0 \times 10^{21} \mathrm{n} / \mathrm{cm}^{2}$ indicate significant enhancement of CGRs in the NWC BWR environment. For these irradiation conditions, the CGRs under continuous cycling are slightly higher than the rates predicted by the Shack/Kassner model for nonirradiated austenitic SSs in high-purity water with 8 ppm DO. The CGRs under SCC conditions are a factor of $\approx 5$ higher than the disposition curve proposed in NUREG-0313 for sensitized austenitic SSs. The CGRs of Type 304 SS irradiated to 0.9 and $2.0 \times 10^{21} \mathrm{n} / \mathrm{cm}^{2}$ and of Types 304 and 316 SS irradiated to $2.0 \times 10^{21} \mathrm{n} / \mathrm{cm}^{2}$ are comparable.

In low-DO BWR environments, the CGRs of the irradiated steels decreased by an order of magnitude in tests where $\mathrm{K}$ values clearly met the validity criteria, e.g., Heat C3 of Type 304 SS irradiated to $0.9 \times 10^{21} \mathrm{n} / \mathrm{cm}^{2}$ and Heat C16 of Type $316 \mathrm{SS}$ irradiated to $2 \times 10^{21} \mathrm{n} / \mathrm{cm}^{2}$. The beneficial effect of decreased DO was not observed for Heat C3 of Type 304 SS irradiated to $2 \times 10^{21} \mathrm{n} / \mathrm{cm}^{2}$; it is possible that this different behavior is associated with the loss of constraint in the specimen due to the high $\mathrm{K}$.

Type $304 \mathrm{SS}$ irradiated to $0.3 \times 10^{21} \mathrm{n} / \mathrm{cm}^{2}(0.45 \mathrm{dpa})$ shows very little environmental enhancement of CGRs in the NWC BWR environment; under continuous cycling, the CGRs are comparable to those predicted by the Shack/Kassner model for nonirradiated austenitic SSs in 
high-purity water with $0.2 \mathrm{ppm}$ DO. The CGRs for Type 304 irradiated to $0.3 \times 10^{21} \mathrm{n} / \mathrm{cm}^{2}$ under SCC conditions are below the disposition curve for sensitized SSs in water with $8 \mathrm{ppm}$ DO given in NUREG-0313. 


\section{References}

1. S. M. Bruemmer et al., "Critical Issue Reviews for the Understanding and Evaluation of Irradiation-Assisted Stress Corrosion Cracking," EPRI TR-107159, Electric Power Research Institute, Palo Alto, CA (1996).

2. M. L. Herrera, et al., "Evaluation of the Effects of Irradiation on the Fracture Toughness of BWR Internal Components," in Proc. ASME/JSME 4th Intl. Conf. on Nucl. Eng. (ICONE-4) Vol. 5, A. S. Rao, R. M. Duffey, and D. Elias, eds., American Society of Mechanical Engineers, New York, pp. 245-251 (1996).

3. W. J. Mills, "Fracture Toughness of Type 304 and 316 Stainless Steels and their Welds," Intl. Mater. Rev. 42, 45-82 (1997).

4. H. Kanasaki, I. Satoh, M. Koyama, T. Okubo, T. R. Mager, and R. G. Lott, "Fatigue and Stress Corrosion Cracking Behaviors of Irradiated Stainless Steels in PWR Primary Water," Proc. 5th Intl. Conf. On Nuclear Engineering, ICONE5-2372, pp. 1-7 (1997).

5. P. L. Andresen, F. P. Ford, S. M. Murphy, and J. M. Perks, "State of Knowledge of Radiation Effects on Environmental Cracking in Light Water Reactor Core Materials," Proc. 4th Intl. Symp. on Environmental Degradation of Materials in Nuclear Power Systems - Water Reactors, NACE, pp. 1.83-1.121 (1990).

6. A. Jenssen and L. G. Ljungberg, "Irradiation Assisted Stress Corrosion Cracking of Stainless Alloys in BWR Normal Water Chemistry and Hydrogen Water Chemistry," Proc. Sixth Intl. Symp. on Environmental Degradation of Materials in Nuclear Power Systems Water Reactor, R. E. Gold and E. P. Simonen, eds., Minerals, Metals \& Materials Society, 547-553 (1993).

7. P. J. Maziasz and C. J. McHargue, "Microstructural Evolution in Annealed Austenitic Steels during Neutron Irradiation,” Int. Met. Rev. 32, 190 (1987).

8. P. J. Maziasz, "Overview of Microstructural Evolution in Neutron-Irradiated Austenitic Stainless Steels,” J. Nucl. Mater. 205, 118-145 (1993).

9. F. A. Garner, "Evolution of Microstructures in Face-Centered Cubic Metals during Neutron Irradiation,” J. Nucl. Mater. 205, 98-111 (1993).

10. J. Dufresne, B. Henry, and H. Larsson, "Fracture Toughness of Irradiated AISI 304 and 316L Stainless Steels," in Effects of Radiation on Structural Materials, ASTM STP 683, J. A. Sprague and D. Kramer, eds., American Society for Testing and Materials, Philadelphia, pp. 511-528 (1979).

11. C. Picker, A. L. Stott, and H. Cocks, "Effects of Low-Dose Fast Neutron Irradiation on the Fracture Toughness of Type 316 Stainless Steel and Weld Metal," in Proc. Specialists Meeting on Mechanical Properties of Fast Reactor Structural Materials, Chester, UK, Paper IWGFR 49/440-4 (1983). 
12. F. H. Huang, "The Fracture Characterization of Highly Irradiated Type 316 Stainless Steel,” Int. J. Fracture 25, 181-193 (1984).

13. J. Bernard and G. Verzeletti, "Elasto-Plastic Fracture Mechanics Characterization of Type $316 \mathrm{H}$ Irradiated Stainless Steel up to 1 dpa," in Effects of Radiation on Materials: 12th Intl. Symp., ASTM STP 870, F. A. Garner and J. S. Perrin, eds., American Society for Testing and Materials, Philadelphia, pp. 619-641 (1985).

14. W. J. Mills, L. A. James, and L. D. Blackburn, 1985, "Results of Fracture Mechanics Tests on PNC SU 304 Plate,” Westinghouse Hanford Report HEDL-7544, Hanford Engineering Development Laboratory, Richland, WA.

15. W. J. Mills, "Fracture Toughness of Irradiated Stainless Steel Alloys," Nucl. Technol. 82, 290-303 (1988).

16. D. J. Michel and R. A. Gray, "Effects of Irradiation on the Fracture Toughness of FBR Structural Materials,” J. Nucl. Mater. 148, 194-203 (1987).

17. P. Ould, P. Balladon, and Y. Meyzaud, Bull. Cercle Etud. Metaux 15, 31.1-31.12 (1988).

18. E. V. Van Osch, M. G. Horsten, and M. I. De Vries, "Fracture Toughness of PWR Internals," ECN Contribution to CEC Contract on PWR Internals-Part 2 (ETNU/CT/94/0136-F), ECN-I-97-010 (71747/NUC/EvO/mh/006274), Netherlands Energy Research Foundation ECN, Petten, the Netherlands (1997).

19. K. S. Brown and G. M. Gordon, "Effects of BWR Coolant Chemistry on the Propensity for IGSCC Initiation and Growth in Creviced Reactor Internals Components," Proc. Third Intl. Symp. on Environmental Degradation of Materials in Nuclear Power Systems - Water Reactor, AIME, pp. 243-248 (1987).

20. G. M. Gordon and K. S. Brown, "Dependence of Creviced BWR Component IGSCC Behavior on Coolant Chemistry," Proc. 4th Intl. Symp. on Environmental Degradation of Materials in Nuclear Power Systems - Water Reactor, Daniel Cubicciotti, ed., NACE, pp. 14.46-14.61 (1990).

21. F. Garzarolli, D. Alter, and P. Dewes, "Deformability of Austenitic Stainless Steels and Nickel-Base Alloys in the Core of a Boiling and a Pressurized Water Reactor," Proc. Intl. Symp. on Environmental Degradation of Materials in Nuclear Power Systems - Water Reactor, ANS, pp. 131-138 (1986).

22. M. Kodama et al., "IASCC Susceptibility of Austenitic Stainless Steels Irradiated to High Neutron Fluence," Proc. Sixth Intl. Symp. on Environmental Degradation of Materials in Nuclear Power Systems - Water Reactor, R. E. Gold and E. P. Simonen, eds., Minerals, Metals \& Materials Society, pp. 583-588 (1993).

23. M. Kodama et al., "Effects of Fluence and Dissolved Oxygen on IASCC in Austenitic Stainless Steels," Proc. Fifth Intl. Symp. on Environmental Degradation of Materials in Nuclear Power Systems - Water Reactor, American Nuclear Society, pp. 948-954 (1991). 
24. W. L. Clark and A. J. Jacobs, "Effect of Radiation Environment on SCC of Austenitic Materials," Proc. First Intl. Symp. on Environmental Degradation of Materials in Nuclear Power Systems - Water Reactor, NACE, p. 451 (1983).

25. A. Jenssen and L. G. Ljungberg, "Irradiation Assisted Stress Corrosion Cracking of Stainless Alloys in BWR Normal Water Chemistry and Hydrogen Water Chemistry," Proc. Sixth Intl. Symp. on Environmental Degradation of Materials in Nuclear Power Systems Water Reactor, R. E. Gold and E. P. Simonen, eds., Minerals, Metals \& Materials Society, pp. 547-553 (1993).

26. A. Jenssen and L. G. Ljungberg, "Irradiation Assisted Stress Corrosion Cracking. Post Irradiation CERT Tests of Stainless Steels in a BWR Test Loop," Proc. Seventh Intl. Symp. on Environmental Degradation of Materials in Nuclear Power Systems - Water Reactor, G. Airey et al., eds., NACE, pp. 1043-1052 (1995).

27. H. M. Chung, W. E. Ruther, R. V. Strain, and W. J. Shack, "Irradiated-Assisted Stress Corrosion Cracking of Model Austenitic Stainless Steel Alloys," NUREG/CR-6687, ANL-00/21 (Oct. 2000).

28. H. M. Chung, R. V. Strain, and R. W. Clark, "Slow-Strain-Rate-Tensile Test of Model Austenitic Stainless Steels Irradiated in the Halden Reactor," in Environmentally Assisted Cracking in Light Water Reactors Annual Report January-December 2001, NUREG/CR-4667, Vol. 32, ANL-02/33, pp. 19-28 (2003).

29. O. K. Chopra, E. E. Gruber, and W. J. Shack, "Fracture Toughness Characterization of Type 304 Stainless Steel Irradiated in the Halden Reactor," Proc. of the 8th Intl. Conf. on Nuclear Engineering, ICONE8-8301, ASME (2000).

30. E. E. Gruber and O. K. Chopra, "Fracture Toughness J-R Test of Austenitic Stainless Steels Irradiated in Halden Reactor," in Environmentally Assisted Cracking in Light Water Reactors Semiannual Report January 1999-June 1999, NUREG/CR-4667, Vol. 28, ANL-00/7, pp. 27-35 (July 2000).

31. E. E. Gruber and O. K. Chopra, "Fracture Toughness J-R Test of Austenitic Stainless Steels Irradiated in Halden Reactor," in Environmentally Assisted Cracking in Light Water Reactors Semiannual Report July 1999-December 1999, NUREG/CR-4667, Vol. 29, ANL-00/23, pp. 30-38 (Nov. 2000).

32. E. E. Gruber and O. K. Chopra, "Fracture Toughness J-R Test of Austenitic Stainless Steels Irradiated in Halden Reactor," in Environmentally Assisted Cracking in Light Water Reactors Semiannual Report July 1998-December 1998, NUREG/CR-4667, Vol. 31, ANL-01/09, pp. 33-37 (April 2002).

33. E. E. Gruber and O. K. Chopra, "Fracture Toughness J-R Test of Austenitic Stainless Steels Irradiated in Halden Reactor," in Environmentally Assisted Cracking in Light Water Reactors Semiannual Report July 1998-December 1998, NUREG/CR-4667, Vol. 27, ANL-99/11, pp. 39-45 (Oct. 1999). 
34. P. L. Andresen, "Similarity of Cold Work and Radiation Hardening in Enhancing Yield Strength and SCC Growth of Stainless Steel in Hot Water," Corrosion/02, Paper 02509, NACE (2002).

35. W. J. Shack and T. F. Kassner, "Review of Environmental Effects on Fatigue Crack Growth of Austenitic Stainless Steels,” NUREG/CR-6176, ANL-94/1 (May 1994).

36. L. A. James and D. P. Jones, "Fatigue Crack Growth Correlation for Austenitic Stainless Steels in Air," Proc. Conf. on Predictive Capabilities in Environmentally-Assisted Cracking, PVP Vol. 99, R. Rungta, ed., American Society of Mechanical Engineers, New York, pp. 363-414 (1985).

37. W. S. Hazelton and W. H. Koo, "Technical Report on Material Selection and Processing Guidelines for BWR Coolant Pressure Boundary Piping, Final Report,” NUREG-0313, Rev. 2 (1988).

38. A. L. Hiser, "Fracture Toughness Characterization of Nuclear Piping Steels," NUREG/CR-5118, MEA-2325, Materials Engineering Associates, Inc., Lanham, MD (1989).

39. G. M. Wilkowski et al., "Degraded Piping Program - Phase II, Semiannual Report," NUREG/CR-4082, Vol. 2 (1985).

40. Mills, W. J., "Heat-to-Heat Variations in the Fracture Toughness of Austenitic Stainless Steels,” Eng. Fracture Mech. 30, 469-492 (1988).

41. M. G. Vassilaros, R. A. Hays, and J. P. Gudas, "Investigation of the Ductile Fracture Properties of Type 304 Stainless Steel Plate, Welds, and 4-Inch Pipe," in Proc. 12th Water Reactor Safety Information Meeting, NUREG/CP-0058, Vol. 4, U.S. Nuclear Regulatory Commission, pp. 176-189 (1985). 
Appendix 
Table A-1. Test data for specimen Y4-03 of thermally aged CF-8M cast SS tested at $288^{\circ} \mathrm{C}$

$\begin{array}{ll}\text { Test Number } & : \text { JR-18 } \\ \text { Material Type } & : \text { CF-8M Cast SS } \\ \text { Aging Temp. } & : 400^{\circ} \mathrm{C} \\ \text { Irradiation Temp. } & :- \\ \text { Thickness } & : 6.515 \mathrm{~mm} \\ \text { Width } & : 12.005 \mathrm{~mm} \\ \text { Modulus E } & : 180 \mathrm{GPa} \\ \text { Initial Crack } & : 7.43 \mathrm{~mm} \\ \text { Final Crack } & : 8.90 \mathrm{~mm} \\ \text { Final Crack } & : 8.97 \mathrm{~mm}\end{array}$

$\begin{array}{ll}\text { Test Temp. } & : 288^{\circ} \mathrm{C} \\ \text { Heat Number } & : 4331 \\ \text { Aging Time } & : 700 \mathrm{~h} \\ \text { Fluence } & :- \\ \text { Net Thickness } & : 5.879 \mathrm{~mm} \\ \text { Flow Stress } & : 410.5 \mathrm{MPa} \\ & \\ \text { Init. a/W } & : 0.62 \text { (Measured) } \\ \text { Final a/W } & : 0.74 \text { (Measured) } \\ \text { Final a/W } & : 0.75 \text { (Compliance) }\end{array}$

\begin{tabular}{|c|c|c|c|c|c|c|}
\hline \multirow[b]{2}{*}{ No. } & \multirow{2}{*}{$\begin{array}{c}\text { Load } \\
(\mathrm{kN})\end{array}$} & \multirow{2}{*}{$\begin{array}{c}\text { Deflection } \\
\text { (mm) }\end{array}$} & \multicolumn{2}{|c|}{ Unloading Compliance } & \multicolumn{2}{|c|}{ DC Potential Method } \\
\hline & & & $\mathrm{J}\left(\mathrm{kJ} / \mathrm{m}^{2}\right)$ & $\Delta \mathrm{a}(\mathrm{mm})$ & $\mathrm{J}\left(\mathrm{kJ} / \mathrm{m}^{2}\right)$ & $\Delta \mathrm{a}(\mathrm{mm})$ \\
\hline 0 & 0.0885 & 0.000 & & & & \\
\hline 1 & 1.6352 & 0.309 & 34.5 & 0.103 & 32.9 & 0.021 \\
\hline 2 & 1.7575 & 0.398 & 48.6 & 0.016 & 45.6 & 0.030 \\
\hline 3 & 1.8598 & 0.490 & 63.3 & -0.030 & 59.3 & 0.039 \\
\hline 4 & 1.9474 & 0.583 & 76.7 & 0.042 & 74.0 & 0.047 \\
\hline 5 & 2.0168 & 0.678 & 93.2 & -0.001 & 89.5 & 0.057 \\
\hline 6 & 2.0747 & 0.774 & 110.1 & -0.014 & 105.7 & 0.067 \\
\hline 7 & 2.1142 & 0.871 & 126.9 & -0.013 & 120.7 & 0.159 \\
\hline 8 & 2.1325 & 0.971 & 144.1 & -0.003 & 136.2 & 0.211 \\
\hline 9 & 2.1641 & 1.069 & 158.8 & 0.061 & 152.2 & 0.262 \\
\hline 10 & 2.1930 & 1.169 & 175.9 & 0.077 & 168.6 & 0.309 \\
\hline 11 & 2.1907 & 1.269 & 192.1 & 0.120 & 185.0 & 0.365 \\
\hline 12 & 2.1627 & 1.373 & 205.9 & 0.209 & 200.2 & 0.451 \\
\hline 13 & 2.1592 & 1.475 & 220.9 & 0.266 & 215.4 & 0.517 \\
\hline 14 & 2.1463 & 1.577 & 235.9 & 0.325 & 230.8 & 0.584 \\
\hline 15 & 2.1369 & 1.679 & 251.6 & 0.370 & 245.9 & 0.652 \\
\hline 16 & 2.1329 & 1.781 & 266.0 & 0.432 & 261.3 & 0.712 \\
\hline 17 & 2.1169 & 1.884 & 282.4 & 0.468 & 276.9 & 0.771 \\
\hline 18 & 2.0898 & 1.988 & 293.2 & 0.569 & 291.6 & 0.841 \\
\hline 19 & 2.0822 & 2.091 & 307.6 & 0.621 & 306.6 & 0.897 \\
\hline 20 & 2.0395 & 2.196 & 321.1 & 0.688 & 321.9 & 0.956 \\
\hline 21 & 1.9870 & 2.302 & 331.2 & 0.781 & 335.5 & 1.027 \\
\hline 22 & 1.9336 & 2.408 & 337.5 & 0.903 & 347.7 & 1.104 \\
\hline 23 & 1.8696 & 2.515 & 345.5 & 1.004 & 359.9 & 1.174 \\
\hline 24 & 1.8184 & 2.621 & 348.7 & 1.139 & 371.5 & 1.243 \\
\hline 25 & 1.7353 & 2.731 & 347.2 & 1.309 & 382.5 & 1.316 \\
\hline 26 & 1.6788 & 2.837 & 348.2 & 1.444 & 390.6 & 1.399 \\
\hline 27 & 1.6272 & 2.943 & 354.2 & 1.541 & 399.1 & 1.471 \\
\hline
\end{tabular}

Power-Law Fit

Unloading Compliance

Coeff. C : $334 \mathrm{~kJ} / \mathrm{m}^{2}$

DC Potential Method

Coeff. C : $324 \mathrm{~kJ} / \mathrm{m}^{2}$
$\mathrm{J}=\mathrm{C}(\Delta \mathrm{a})^{\mathrm{n}}$

$\mathrm{J}_{\mathrm{Ic}} \quad: 258 \mathrm{~kJ} / \mathrm{m}^{2}$

Exponent $\mathrm{n}: 0.25$

$\mathrm{J}_{\mathrm{Ic}} \quad: 162 \mathrm{~kJ} / \mathrm{m}^{2}$

Exponent n : 0.57
(15 Data)

Fit Coeff. $\mathrm{R}: 0.907$

(20 Data)

Fit Coeff. R : 0.997 


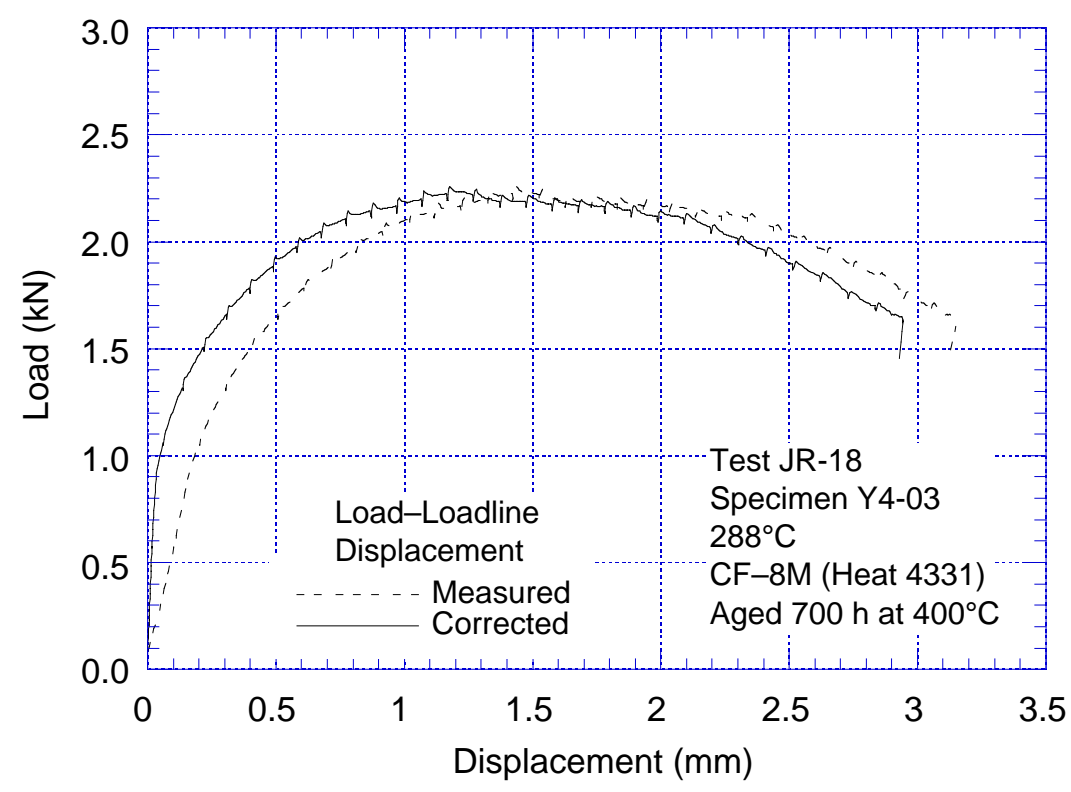

Figure A-1.1. Load-vs.-loadline displacement curve for specimen Y4-03 of thermally aged CF-8M cast SS tested at $288^{\circ} \mathrm{C}$

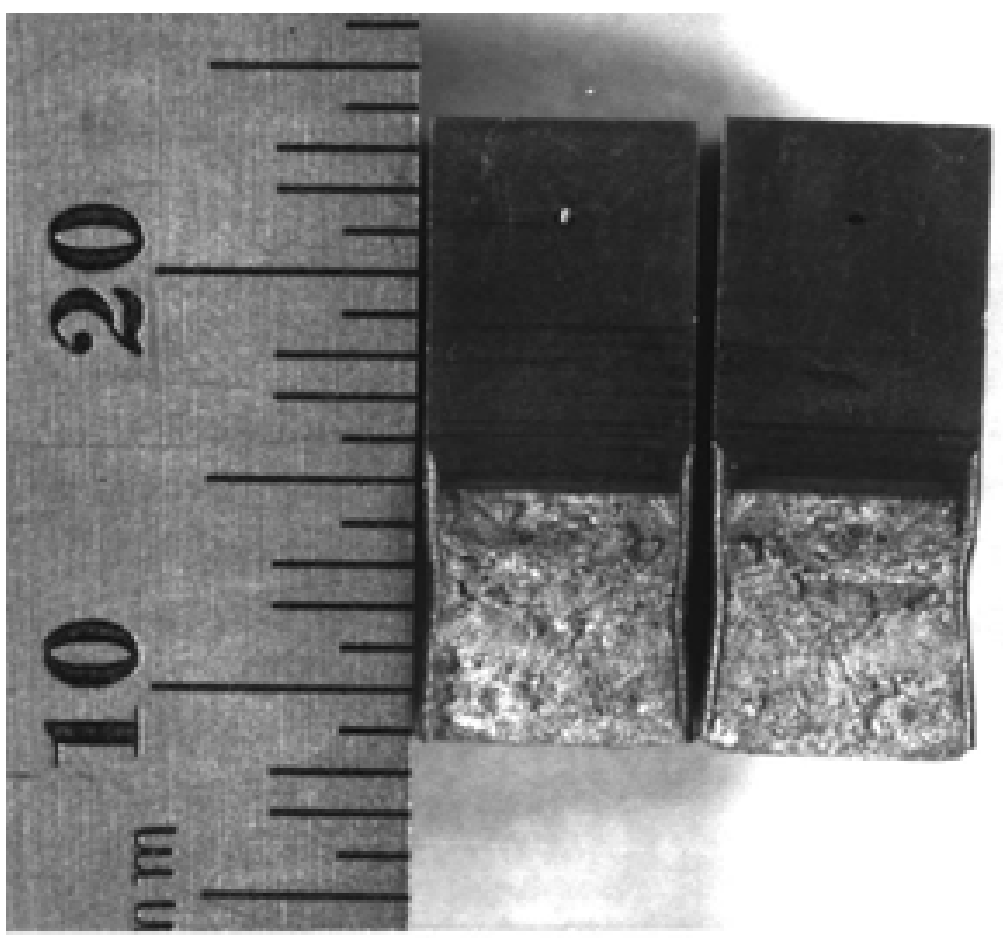

Figure A-1.2. Fracture surface of specimen $Y 4-03$ tested at $288^{\circ} \mathrm{C}$ 
Table A-2. Test data for specimen Y4-02 of thermally aged CF-8M cast SS tested at $288^{\circ} \mathrm{C}$

$\begin{array}{ll}\text { Test Number } & : \text { JR-10 } \\ \text { Material Type } & : \text { CF-8M Cast SS } \\ \text { Aging Temp. } & : 400^{\circ} \mathrm{C} \\ \text { Irradiation Temp. } & :- \\ \text { Thickness } & : 6.515 \mathrm{~mm} \\ \text { Width } & : 12.003 \mathrm{~mm} \\ \text { Modulus E } & : 180 \mathrm{GPa} \\ \text { Initial Crack } & : 7.51 \mathrm{~mm} \\ \text { Final Crack } & : 9.32 \mathrm{~mm} \\ \text { Final Crack } & : 9.79 \mathrm{~mm}\end{array}$

$\begin{array}{ll}\text { Test Temp. } & : 288^{\circ} \mathrm{C} \\ \text { Heat Number } & : 4331 \\ \text { Aging Time } & : 700 \mathrm{~h} \\ \text { Fluence } & :- \\ \text { Net Thickness } & : 5.857 \mathrm{~mm} \\ \text { Flow Stress } & : 410.5 \mathrm{MPa} \\ & \\ \text { Init. a/W } & : 0.63 \text { (Measured) } \\ \text { Final a/W } & : 0.78 \text { (Measured) } \\ \text { Final a/W } & : 0.82 \text { (Compliance) }\end{array}$

\begin{tabular}{|c|c|c|c|c|c|c|}
\hline \multirow[b]{2}{*}{ No. } & \multirow{2}{*}{$\begin{array}{c}\text { Load } \\
(\mathrm{kN})\end{array}$} & \multirow{2}{*}{$\begin{array}{l}\text { Deflection } \\
(\mathrm{mm})\end{array}$} & \multicolumn{2}{|c|}{ Unloading Compliance } & \multicolumn{2}{|c|}{ DC Potential Method } \\
\hline & & & $\mathrm{J}\left(\mathrm{kJ} / \mathrm{m}^{2}\right)$ & $\Delta \mathrm{a}(\mathrm{mm})$ & $\mathrm{J}\left(\mathrm{kJ} / \mathrm{m}^{2}\right)$ & $\Delta \mathrm{a}(\mathrm{mm})$ \\
\hline 0 & 0.0454 & 0.000 & & & & \\
\hline 1 & 1.3318 & 0.126 & 11.3 & 0.090 & 10.2 & 0.006 \\
\hline 2 & 1.5435 & 0.207 & 21.7 & 0.135 & 20.3 & 0.012 \\
\hline 3 & 1.8447 & 0.380 & 49.2 & -0.127 & 45.7 & 0.027 \\
\hline 4 & 1.9550 & 0.471 & 61.3 & 0.015 & 60.3 & 0.036 \\
\hline 5 & 2.2615 & 0.846 & 129.8 & -0.147 & 127.6 & 0.076 \\
\hline 6 & 2.3153 & 0.942 & 142.5 & -0.003 & 146.1 & 0.087 \\
\hline 7 & 2.3602 & 1.039 & 158.0 & 0.075 & 165.0 & 0.098 \\
\hline 8 & 2.3776 & 1.139 & 174.3 & 0.158 & 183.5 & 0.148 \\
\hline 9 & 2.3923 & 1.240 & 190.4 & 0.245 & 201.3 & 0.202 \\
\hline 10 & 2.4221 & 1.338 & 207.1 & 0.313 & 218.4 & 0.259 \\
\hline 11 & 2.4132 & 1.440 & 224.0 & 0.395 & 236.7 & 0.311 \\
\hline 12 & 2.4189 & 1.537 & 242.1 & 0.441 & 253.7 & 0.367 \\
\hline 13 & 2.4221 & 1.638 & 263.4 & 0.454 & 270.7 & 0.433 \\
\hline 14 & 2.3963 & 1.741 & 284.2 & 0.479 & 287.4 & 0.502 \\
\hline 15 & 2.3313 & 1.846 & 304.8 & 0.504 & 303.1 & 0.581 \\
\hline 16 & 2.2815 & 1.951 & 325.9 & 0.516 & 317.4 & 0.668 \\
\hline 17 & 2.2210 & 2.056 & 338.7 & 0.607 & 331.3 & 0.750 \\
\hline 18 & 2.1712 & 2.161 & 356.1 & 0.644 & 344.9 & 0.828 \\
\hline 19 & 2.0689 & 2.270 & 353.6 & 0.856 & 357.3 & 0.920 \\
\hline 20 & 1.9830 & 2.379 & 359.4 & 0.981 & 366.8 & 1.023 \\
\hline 21 & 1.8812 & 2.488 & 347.5 & 1.245 & 374.5 & 1.133 \\
\hline 22 & 1.7815 & 2.597 & 343.0 & 1.435 & 380.2 & 1.245 \\
\hline 23 & 1.7143 & 2.704 & 345.7 & 1.569 & 385.9 & 1.347 \\
\hline 24 & 1.6143 & 2.815 & 335.4 & 1.797 & 389.5 & 1.465 \\
\hline 25 & 1.5329 & 2.923 & 333.6 & 1.950 & 394.1 & 1.560 \\
\hline 26 & 1.4724 & 3.029 & 337.5 & 2.060 & 397.5 & 1.658 \\
\hline 27 & 1.4208 & 3.136 & 338.5 & 2.188 & 402.4 & 1.740 \\
\hline 28 & 1.3745 & 3.241 & 343.7 & 2.284 & 408.5 & 1.813 \\
\hline
\end{tabular}

Power-Law Fit

Unloading Compliance

Coeff. C $\quad: 341 \mathrm{~kJ} / \mathrm{m}^{2}$

DC Potential Method

Coeff. C : $351 \mathrm{~kJ} / \mathrm{m}^{2}$
$J=C(\Delta a)^{n}$

$\mathrm{J}_{\mathrm{Ic}} \quad: 252 \mathrm{~kJ} / \mathrm{m}^{2}$

Exponent n : 0.29

$\mathrm{J}_{\mathrm{Ic}} \quad: 254 \mathrm{~kJ} / \mathrm{m}^{2}$

Exponent $n: 0.31$
(14 Data)

Fit Coeff. R : 0.620

(14 Data)

Fit Coeff. R : 0.976 


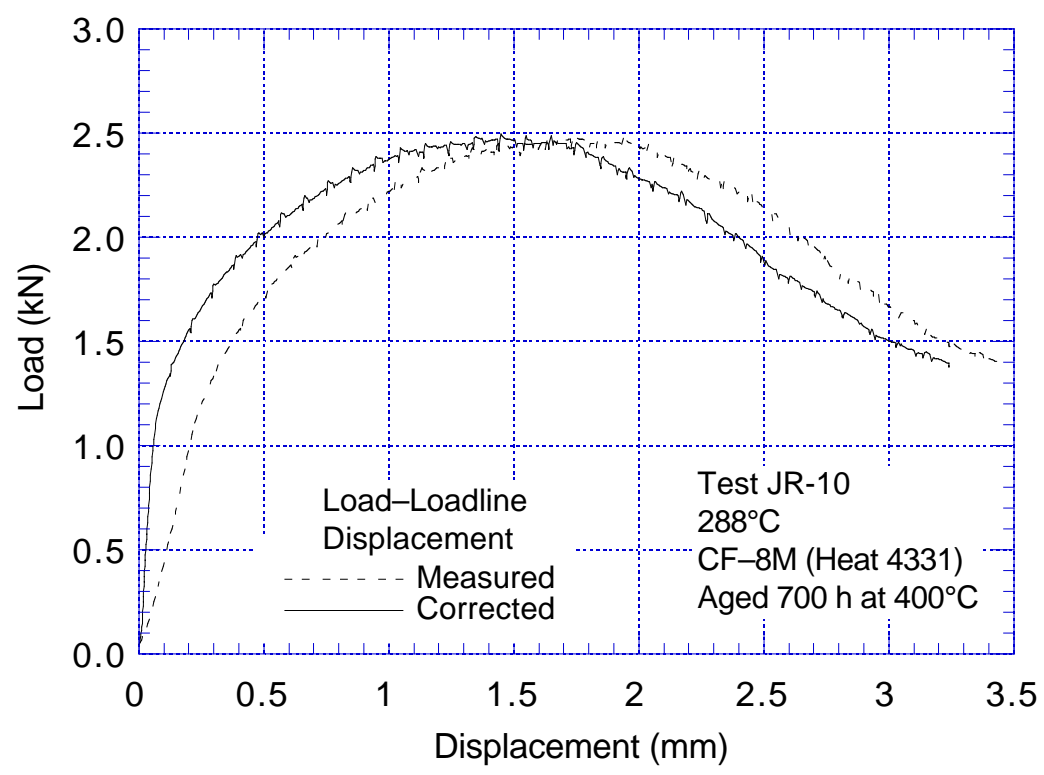

Figure A-2.1. Load-vs.-loadline displacement curve for specimen Y4-02 of thermally aged CF-8M cast SS tested at $288^{\circ} \mathrm{C}$

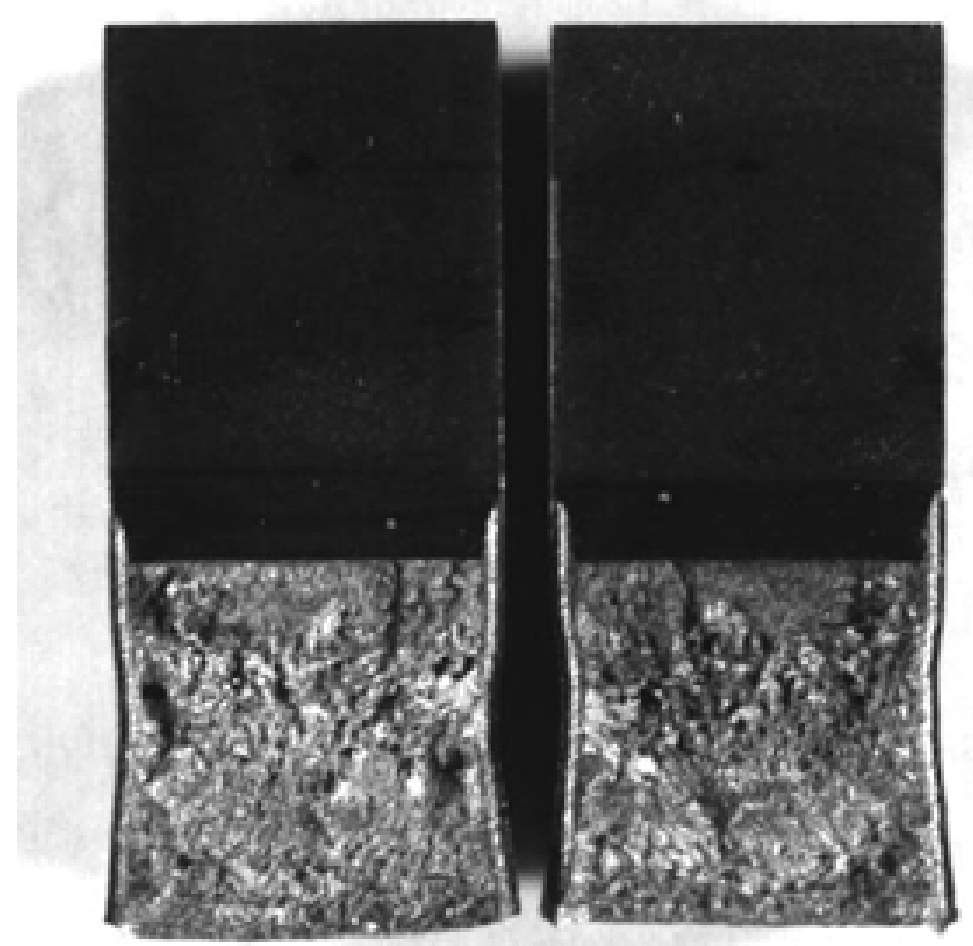

Figure A-2.2. Fracture surface of specimen $\mathrm{Y} 4-02$ tested at $288^{\circ} \mathrm{C}$ 
Table A-3. Test data for specimen $75-03 \mathrm{~T}$ of thermally aged CF-8M cast SS tested at $288^{\circ} \mathrm{C}$

$\begin{array}{ll}\text { Test Number } & : \text { JR-07 } \\ \text { Material Type } & : \text { CF-8M Cast SS } \\ \text { Aging Temp. } & : 400^{\circ} \mathrm{C} \\ \text { Irradiation Temp. } & :- \\ \text { Thickness } & : 6.51 \mathrm{~mm} \\ \text { Width } & : 11.98 \mathrm{~mm} \\ \text { Modulus E } & : 180 \mathrm{GPa} \\ \text { Initial Crack } & : 7.28 \mathrm{~mm} \\ \text { Final Crack } & : 9.35 \mathrm{~mm} \\ \text { Final Crack } & : 8.72 \mathrm{~mm}\end{array}$

$\begin{array}{ll}\text { Test Temp. } & : 288^{\circ} \mathrm{C} \\ \text { Heat Number } & : 75 \\ \text { Aging Time } & : 10,000 \mathrm{~h} \\ \text { Fluence } & :- \\ \text { Net Thickness } & : 5.90 \mathrm{~mm} \\ \text { Flow Stress } & : 410.0 \mathrm{MPa} \\ & \\ \text { Init. a/W } & : 0.61 \text { (Measured) } \\ \text { Final a/W } & : 0.78 \text { (Measured) } \\ \text { Final a/W } & : 0.73 \text { (Compliance) }\end{array}$

\begin{tabular}{|c|c|c|c|c|c|c|}
\hline \multirow[b]{2}{*}{ No. } & \multirow{2}{*}{$\begin{array}{c}\text { Load } \\
(\mathrm{kN})\end{array}$} & \multirow{2}{*}{$\begin{array}{l}\text { Deflection } \\
\text { (mm) }\end{array}$} & \multicolumn{2}{|c|}{ Unloading Compliance } & \multicolumn{2}{|c|}{ DC Potential Method } \\
\hline & & & $\mathrm{J}\left(\mathrm{kJ} / \mathrm{m}^{2}\right)$ & $\Delta \mathrm{a}(\mathrm{mm})$ & $\mathrm{J}\left(\mathrm{kJ} / \mathrm{m}^{2}\right)$ & $\Delta \mathrm{a}(\mathrm{mm})$ \\
\hline 0 & 0.0436 & 0.000 & & & & \\
\hline 1 & 1.0106 & 0.057 & 2.0 & -0.105 & 3.3 & 0.002 \\
\hline 2 & 1.3193 & 0.128 & 10.0 & -0.144 & 10.4 & 0.006 \\
\hline 3 & 1.5284 & 0.209 & 18.5 & 0.064 & 19.9 & 0.012 \\
\hline 4 & 1.8202 & 0.385 & 43.2 & -0.115 & 44.1 & 0.027 \\
\hline 5 & 1.9252 & 0.476 & 54.0 & 0.075 & 57.9 & 0.035 \\
\hline 6 & 2.0155 & 0.569 & 65.1 & 0.293 & 72.7 & 0.044 \\
\hline 7 & 2.0982 & 0.659 & 88.7 & -0.130 & 87.7 & 0.053 \\
\hline 8 & 2.1654 & 0.753 & 103.9 & -0.069 & 103.8 & 0.063 \\
\hline 9 & 2.2201 & 0.849 & 118.4 & 0.005 & 120.8 & 0.073 \\
\hline 10 & 2.2704 & 0.946 & 131.8 & 0.116 & 138.2 & 0.084 \\
\hline 11 & 2.2922 & 1.045 & 148.4 & 0.162 & 156.3 & 0.095 \\
\hline 12 & 2.2904 & 1.147 & 166.6 & 0.184 & 171.4 & 0.205 \\
\hline 13 & 2.2895 & 1.247 & 185.9 & 0.177 & 183.9 & 0.336 \\
\hline 14 & 2.2695 & 1.351 & 200.2 & 0.276 & 195.7 & 0.491 \\
\hline 15 & 2.2375 & 1.455 & 217.3 & 0.316 & 207.2 & 0.638 \\
\hline 16 & 2.2228 & 1.558 & 237.1 & 0.309 & 219.2 & 0.766 \\
\hline 17 & 2.1885 & 1.663 & 249.8 & 0.409 & 232.0 & 0.884 \\
\hline 18 & 2.1151 & 1.770 & 262.2 & 0.505 & 243.1 & 1.033 \\
\hline 19 & 1.9839 & 1.883 & 267.4 & 0.686 & 248.8 & 1.253 \\
\hline 20 & 1.9150 & 1.991 & 273.7 & 0.828 & 251.1 & 1.479 \\
\hline 21 & 1.8491 & 2.099 & 276.1 & 1.010 & 255.4 & 1.660 \\
\hline 22 & 1.7651 & 2.208 & 280.7 & 1.159 & 260.9 & 1.832 \\
\hline 23 & 1.6387 & 2.322 & 271.7 & 1.442 & 261.9 & 2.074 \\
\hline
\end{tabular}

Power-Law Fit

Unloading Compliance

Coeff. C : $277 \mathrm{~kJ} / \mathrm{m}^{2}$

DC Potential Method

Coeff. C : $233 \mathrm{~kJ} / \mathrm{m}^{2}$
$\mathrm{J}=\mathrm{C}(\Delta \mathrm{a})^{\mathrm{n}}$

$\mathrm{J}_{\mathrm{Ic}} \quad: 225 \mathrm{~kJ} / \mathrm{m}^{2}$

Exponent n : 0.19

J $\quad: 180 \mathrm{~kJ} / \mathrm{m}^{2}$

Exponent $\mathrm{n}: 0.22$
(11 Data)

Fit Coeff. R : 0.748

(9 Data)

Fit Coeff. $\mathrm{R}$ : 0.972 


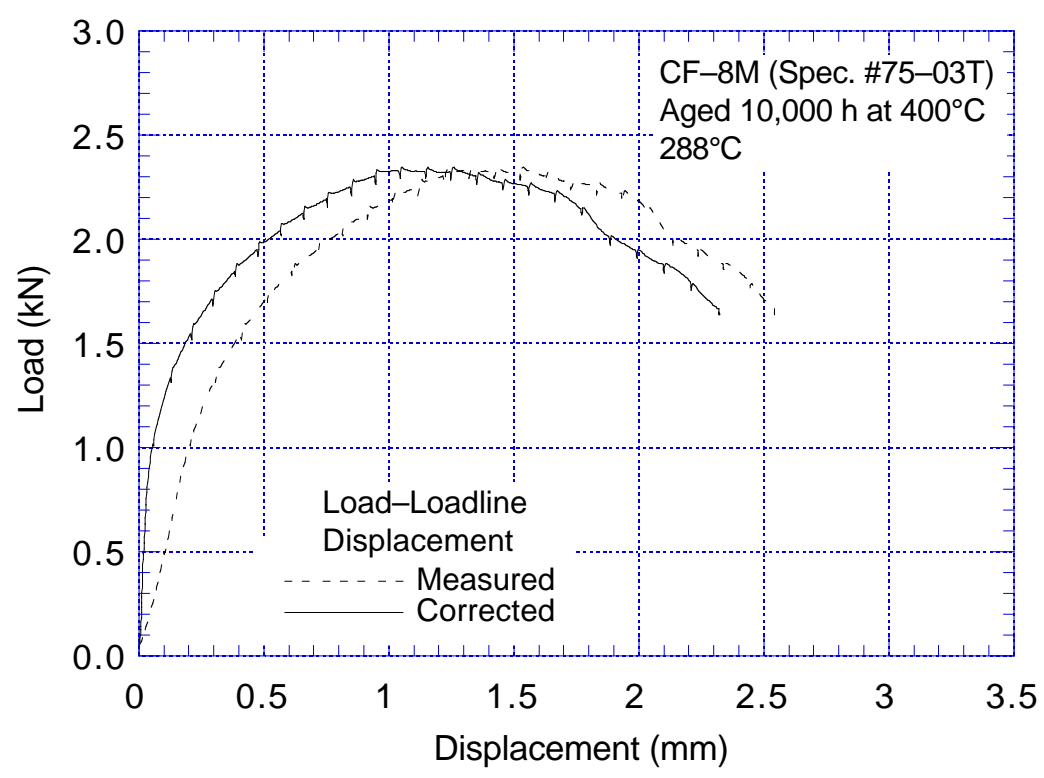

Figure A-3.1. Load-vs.-loadline displacement curve for specimen 75-03T of thermally aged CF-8M cast SS tested at $288^{\circ} \mathrm{C}$

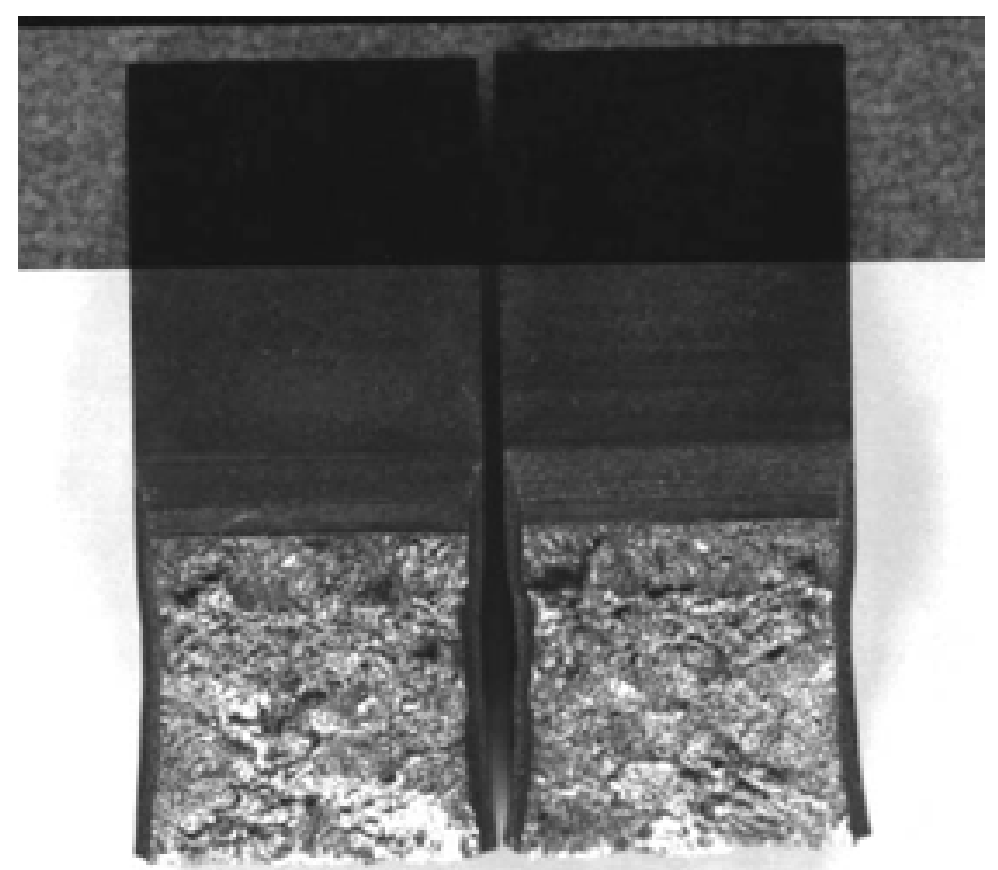

Figure A-3.2. Fracture surface of specimen $75-03 \mathrm{~T}$ tested at $288^{\circ} \mathrm{C}$ 
Table A-4. Test data for specimen $75-04 \mathrm{~T}$ of thermally aged CF-8M cast SS tested at $288^{\circ} \mathrm{C}$

$\begin{array}{ll}\text { Test Number } & : \text { JR-08 } \\ \text { Material Type } & : \text { CF-8M Cast SS } \\ \text { Aging Temp. } & : 400^{\circ} \mathrm{C} \\ \text { Irradiation Temp. } & :- \\ \text { Thickness } & : 6.51 \mathrm{~mm} \\ \text { Width } & : 11.98 \mathrm{~mm} \\ \text { Modulus E } & : 180 \mathrm{GPa} \\ \text { Initial Crack } & : 7.79 \mathrm{~mm} \\ \text { Final Crack } & : 9.89 \mathrm{~mm} \\ \text { Final Crack } & : 10.07 \mathrm{~mm}\end{array}$

$\begin{array}{ll}\text { Test Temp. } & : 288^{\circ} \mathrm{C} \\ \text { Heat Number } & : 75 \\ \text { Aging Time } & : 10,000 \mathrm{~h} \\ \text { Fluence } & :- \\ \text { Net Thickness } & : 5.87 \mathrm{~mm} \\ \text { Flow Stress } & : 410.0 \mathrm{MPa} \\ & \\ \text { Init. a/W } & : 0.65 \text { (Measured) } \\ \text { Final a/W } & : 0.83 \text { (Measured) } \\ \text { Final a/W } & : 0.84 \text { (Compliance) }\end{array}$

\begin{tabular}{|c|c|c|c|c|c|c|}
\hline \multirow[b]{2}{*}{ No. } & \multirow{2}{*}{$\begin{array}{c}\text { Load } \\
(\mathrm{kN})\end{array}$} & \multirow{2}{*}{$\begin{array}{c}\text { Deflection } \\
(\mathrm{mm})\end{array}$} & \multicolumn{2}{|c|}{ Unloading Compliance } & \multicolumn{2}{|c|}{ DC Potential Method } \\
\hline & & & $\mathrm{J}\left(\mathrm{kJ} / \mathrm{m}^{2}\right)$ & $\Delta \mathrm{a}(\mathrm{mm})$ & $\mathrm{J}\left(\mathrm{kJ} / \mathrm{m}^{2}\right)$ & $\Delta \mathrm{a}(\mathrm{mm})$ \\
\hline 0 & 0.0436 & 0.000 & & & & \\
\hline 1 & 0.4938 & 0.033 & 0.9 & -0.198 & 1.0 & 0.000 \\
\hline 2 & 1.9252 & 0.829 & 92.5 & -0.063 & 99.8 & 0.062 \\
\hline 3 & 2.0155 & 0.978 & 111.2 & 0.062 & 121.8 & 0.151 \\
\hline 4 & 2.0982 & 1.128 & 131.3 & 0.171 & 142.9 & 0.246 \\
\hline 5 & 2.1654 & 1.279 & 154.1 & 0.238 & 164.1 & 0.347 \\
\hline 6 & 2.2201 & 1.436 & 179.8 & 0.284 & 185.3 & 0.458 \\
\hline 7 & 2.2704 & 1.592 & 203.9 & 0.348 & 203.5 & 0.595 \\
\hline 8 & 2.2922 & 1.752 & 222.6 & 0.474 & 220.4 & 0.738 \\
\hline 9 & 2.2904 & 1.911 & 234.5 & 0.648 & 232.7 & 0.908 \\
\hline 10 & 2.2895 & 2.071 & 240.6 & 0.857 & 245.4 & 1.048 \\
\hline 11 & 2.2695 & 2.230 & 248.0 & 1.027 & 258.4 & 1.175 \\
\hline 12 & 2.2375 & 2.387 & 254.8 & 1.188 & 269.7 & 1.299 \\
\hline 13 & 2.2228 & 2.544 & 268.4 & 1.278 & 283.7 & 1.390 \\
\hline 14 & 2.1885 & 2.705 & 265.5 & 1.531 & 295.1 & 1.520 \\
\hline 15 & 2.1151 & 2.866 & 265.4 & 1.694 & 301.9 & 1.651 \\
\hline 16 & 1.9839 & 3.032 & 255.1 & 1.968 & 304.6 & 1.819 \\
\hline 17 & 1.9150 & 3.192 & 241.8 & 2.176 & 300.8 & 1.978 \\
\hline 18 & 1.8491 & 3.351 & 242.7 & 2.283 & 299.1 & 2.108 \\
\hline
\end{tabular}

Power-Law Fit

Unloading Compliance

Coeff. C : $248 \mathrm{~kJ} / \mathrm{m}^{2}$

DC Potential Method

Coeff. C : $246 \mathrm{~kJ} / \mathrm{m}^{2}$
$\mathrm{J}=\mathrm{C}(\Delta \mathrm{a})^{\mathrm{n}}$

$\mathrm{J}_{\mathrm{Ic}} \quad: 197 \mathrm{~kJ} / \mathrm{m}^{2}$

Exponent $\mathrm{n}: 0.20$

$\mathrm{J}_{\mathrm{Ic}} \quad: 154 \mathrm{~kJ} / \mathrm{m}^{2}$

Exponent $\mathrm{n}: 0.39$
(10 Data)

Fit Coeff. R : 0.931

(10 Data)

Fit Coeff. R : 0.997 


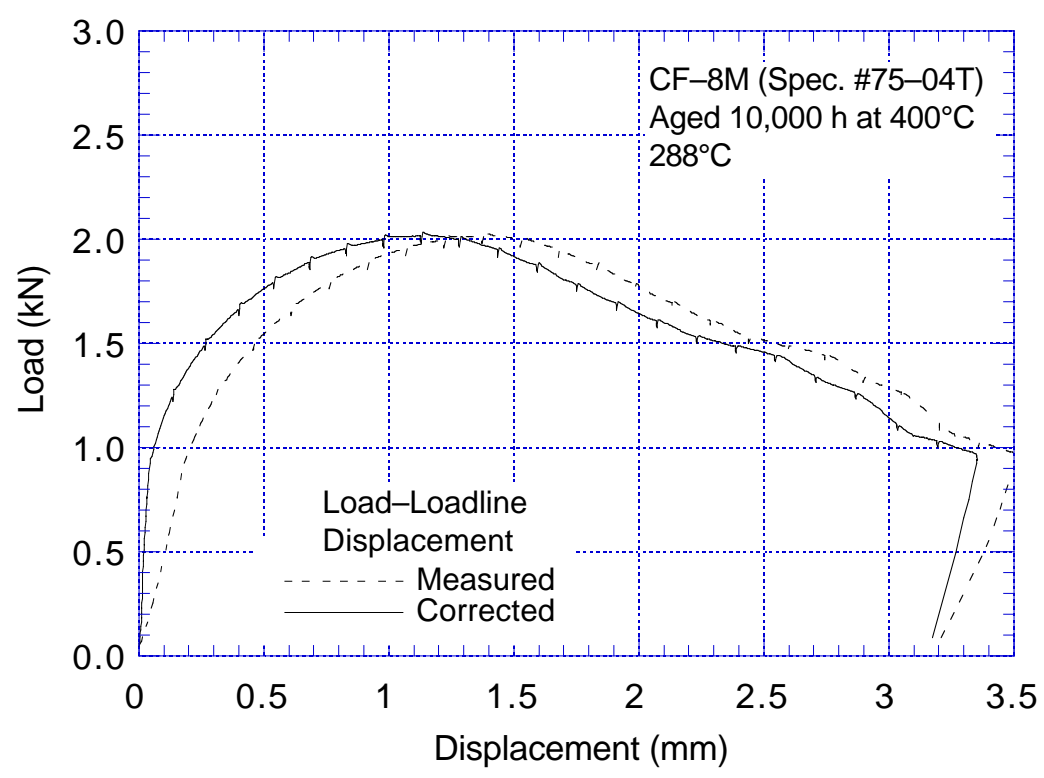

Figure A-4.1. Load-vs.-loadline displacement curve for specimen 75-04T of thermally aged CF-8M cast SS tested at $288^{\circ} \mathrm{C}$

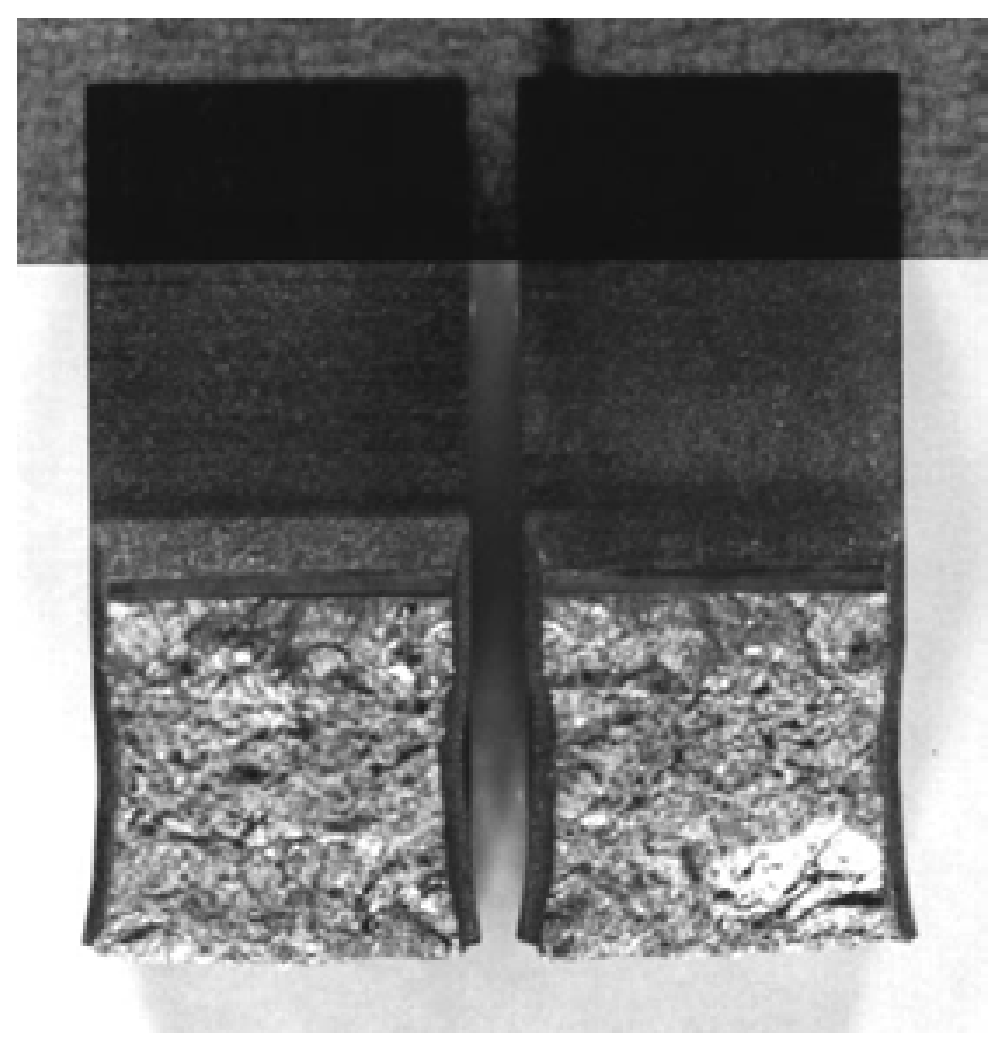

Figure A-4.2. Fracture surface of specimen $75-04 \mathrm{~T}$ tested at $288^{\circ} \mathrm{C}$ 
Table A-5. Test data for specimen $75-10 \mathrm{~T}$ of thermally aged CF-8M cast SS tested at $288^{\circ} \mathrm{C}$

$\begin{array}{ll}\text { Test Number } & : \text { JR-32 } \\ \text { Material Type } & : \text { CF-8M Cast SS } \\ \text { Aging Temp. } & : 400^{\circ} \mathrm{C} \\ \text { Irradiation Temp. } & :- \\ \text { Thickness } & : 6.50 \mathrm{~mm} \\ \text { Width } & : 12.01 \mathrm{~mm} \\ \text { Modulus E } & : 180 \mathrm{GPa} \\ \text { Initial Crack } & : 6.08 \mathrm{~mm} \\ \text { Final Crack } & : 8.75 \mathrm{~mm} \\ \text { Final Crack } & : 8.81 \mathrm{~mm}\end{array}$

$\begin{array}{ll}\text { Test Temp. } & : 288^{\circ} \mathrm{C} \\ \text { Heat Number } & : 75 \\ \text { Aging Time } & : 10,000 \mathrm{~h} \\ \text { Fluence } & :- \\ \text { Net Thickness } & : 5.82 \mathrm{~mm} \\ \text { Flow Stress } & : 410.0 \mathrm{MPa} \\ & \\ \text { Init. a/W } & : 0.51 \text { (Measured) } \\ \text { Final a/W } & : 0.73 \text { (Measured) } \\ \text { Final a/W } & : 0.72 \text { (Compliance) }\end{array}$

\begin{tabular}{|c|c|c|c|c|c|c|}
\hline \multirow[b]{2}{*}{ No. } & \multirow{2}{*}{$\begin{array}{c}\text { Load } \\
(\mathrm{kN})\end{array}$} & \multirow{2}{*}{$\begin{array}{l}\text { Deflection } \\
(\mathrm{mm})\end{array}$} & \multicolumn{2}{|c|}{ Unloading Compliance } & \multicolumn{2}{|c|}{ DC Potential Method } \\
\hline & & & $\mathrm{J}\left(\mathrm{kJ} / \mathrm{m}^{2}\right)$ & $\Delta \mathrm{a}(\mathrm{mm})$ & $\mathrm{J}\left(\mathrm{kJ} / \mathrm{m}^{2}\right)$ & $\Delta \mathrm{a}(\mathrm{mm})$ \\
\hline 0 & 0.0885 & 0.000 & & & & \\
\hline 1 & 2.7615 & 0.368 & 58.5 & -0.496 & 55.8 & 0.038 \\
\hline 2 & 2.9091 & 0.458 & 69.1 & -0.195 & 73.0 & 0.044 \\
\hline 3 & 3.0341 & 0.550 & 85.9 & -0.051 & 91.6 & 0.055 \\
\hline 4 & 3.1404 & 0.642 & 98.7 & 0.264 & 110.7 & 0.062 \\
\hline 5 & 3.2116 & 0.739 & 118.4 & 0.331 & 128.6 & 0.195 \\
\hline 6 & 3.2370 & 0.838 & 142.7 & 0.266 & 146.8 & 0.309 \\
\hline 7 & 3.2792 & 0.937 & 167.1 & 0.209 & 164.9 & 0.426 \\
\hline 8 & 3.3219 & 1.035 & 178.9 & 0.461 & 183.9 & 0.514 \\
\hline 9 & 3.3099 & 1.135 & 204.2 & 0.415 & 203.3 & 0.609 \\
\hline 10 & 3.2659 & 1.240 & 216.2 & 0.654 & 221.5 & 0.747 \\
\hline 11 & 3.2468 & 1.345 & 232.5 & 0.794 & 239.6 & 0.865 \\
\hline 12 & 3.1347 & 1.454 & 258.7 & 0.787 & 257.3 & 0.999 \\
\hline 13 & 2.9554 & 1.567 & 269.0 & 1.005 & 270.9 & 1.185 \\
\hline 14 & 2.8420 & 1.677 & 282.7 & 1.143 & 282.5 & 1.363 \\
\hline 15 & 2.7179 & 1.788 & 287.7 & 1.380 & 294.9 & 1.511 \\
\hline 16 & 2.6173 & 1.896 & 296.5 & 1.552 & 306.6 & 1.656 \\
\hline 17 & 2.4656 & 2.008 & 294.4 & 1.841 & 316.7 & 1.812 \\
\hline 18 & 2.2673 & 2.123 & 305.2 & 1.977 & 322.8 & 2.000 \\
\hline 19 & 2.1098 & 2.235 & 304.0 & 2.215 & 325.3 & 2.194 \\
\hline 20 & 1.9790 & 2.345 & 308.0 & 2.383 & 327.9 & 2.367 \\
\hline 21 & 1.8358 & 2.458 & 307.8 & 2.581 & 330.7 & 2.530 \\
\hline 22 & 1.7366 & 2.567 & 311.3 & 2.731 & 334.8 & 2.667 \\
\hline
\end{tabular}

Power-Law Fit

Unloading Compliance

Coeff. C $\quad: 258 \mathrm{~kJ} / \mathrm{m}^{2}$

DC Potential Method

Coeff. C $\quad: 246 \mathrm{~kJ} / \mathrm{m}^{2}$
$\mathrm{J}=\mathrm{C}(\Delta \mathrm{a})^{\mathrm{n}}$

$\mathrm{J}_{\mathrm{Ic}} \quad: 181 \mathrm{~kJ} / \mathrm{m}^{2} \quad$ (11 Data)

Exponent $n: 0.30$

$\mathrm{J}_{\mathrm{Ic}} \quad: 146 \mathrm{~kJ} / \mathrm{m}^{2}$

Fit Coeff. $\mathrm{R}$ : 0.914

(11 Data)

Exponent $\mathrm{n}: 0.42$
Fit Coeff. R : 0.989 


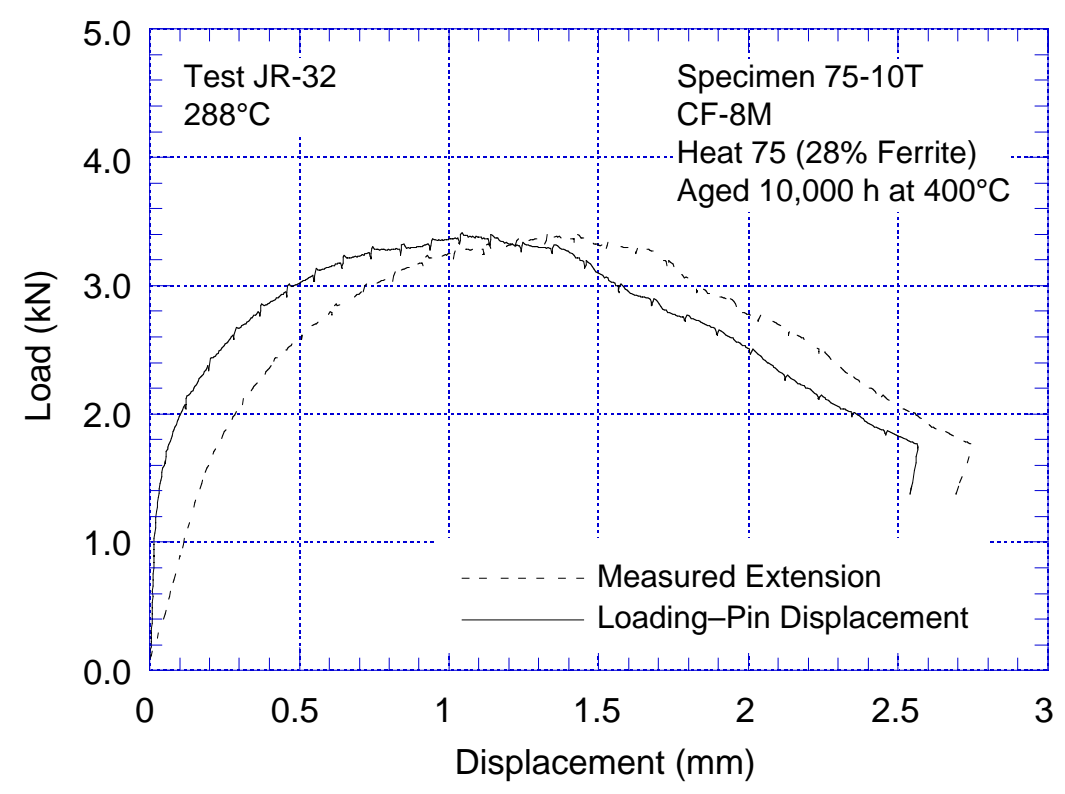

Figure A-5.1. Load-vs.-loadline displacement curve for specimen $75-10 \mathrm{~T}$ of thermally aged CF-8M cast SS tested at $288^{\circ} \mathrm{C}$

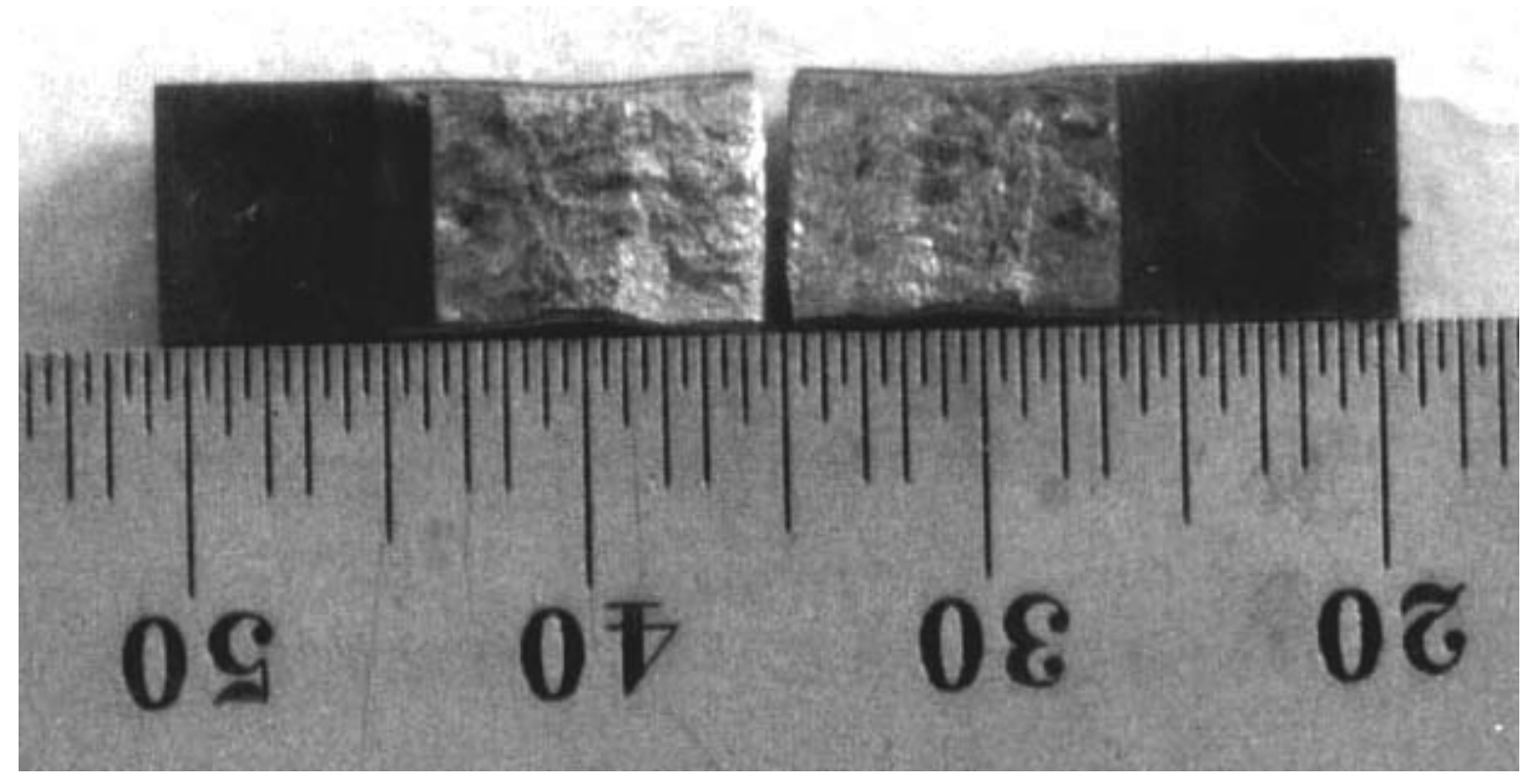

Figure A-5.2. Fracture surface of specimen $75-10 \mathrm{~T}$ tested at $288^{\circ} \mathrm{C}$ 
Table A-6. Test data for specimen $184-38$ of $50 \%$ cold-worked Type $316 N G$ SS tested at $288^{\circ} \mathrm{C}$

$\begin{array}{llll}\text { Test Number } & : \text { JR-12 } & \text { Test Temp. } & : 288^{\circ} \mathrm{C} \\ \text { Material Type } & : 50 \% \text { CW 316NG SS } & \text { Heat Number } & : 18474 \\ \text { Aging Temp. } & :- & \text { Aging Time } & :- \\ \text { Irradiation Temp. } & :- & \text { Fluence } & :- \\ \text { Thickness } & : 6.497 \mathrm{~mm} & \text { Net Thickness } & : 5.819 \mathrm{~mm} \\ \text { Width } & : 12.032 \mathrm{~mm} & \text { Flow Stress } & : 861.0 \mathrm{MPa} \\ \text { Modulus E } & : 175 \mathrm{GPa} & & \\ \text { Initial Crack } & : 7.14 \mathrm{~mm} & \text { Init. a/W } & : 0.59 \text { (Measured) } \\ \text { Final Crack } & : 10.30 \mathrm{~mm} & \text { Final a/W } & : 0.86 \text { (Measured) } \\ \text { Final Crack } & : 9.64 \mathrm{~mm} & \text { Final a/W } & : 0.80 \text { (Compliance) }\end{array}$

\begin{tabular}{|c|c|c|c|c|c|c|}
\hline \multirow[b]{2}{*}{ No. } & \multirow{2}{*}{$\begin{array}{c}\text { Load } \\
(\mathrm{kN})\end{array}$} & \multirow{2}{*}{$\begin{array}{l}\text { Deflection } \\
(\mathrm{mm})\end{array}$} & \multicolumn{2}{|c|}{ Unloading Compliance } & \multicolumn{2}{|c|}{ DC Potential Method } \\
\hline & & & $\mathrm{J}\left(\mathrm{kJ} / \mathrm{m}^{2}\right)$ & $\Delta \mathrm{a}(\mathrm{mm})$ & $\mathrm{J}\left(\mathrm{kJ} / \mathrm{m}^{2}\right)$ & $\Delta \mathrm{a}(\mathrm{mm})$ \\
\hline 0 & 0.0445 & 0.000 & & & & \\
\hline 1 & 1.2522 & 0.045 & 2.1 & 0.048 & 2.1 & 0.001 \\
\hline 2 & 1.9296 & 0.093 & 7.8 & 0.055 & 7.9 & 0.002 \\
\hline 3 & 2.5430 & 0.148 & 17.4 & 0.023 & 17.4 & 0.005 \\
\hline 4 & 3.0577 & 0.208 & 30.1 & 0.184 & 30.2 & 0.009 \\
\hline 5 & 3.4665 & 0.274 & 45.8 & 0.169 & 48.0 & 0.092 \\
\hline 6 & 3.2041 & 0.389 & 72.5 & 0.522 & 79.8 & 0.589 \\
\hline 7 & 2.9932 & 0.505 & 93.9 & 0.779 & 99.0 & 1.069 \\
\hline 8 & 2.2784 & 0.658 & 115.2 & 1.169 & 118.1 & 1.733 \\
\hline 9 & 1.8362 & 0.792 & 121.5 & 1.594 & 121.3 & 2.257 \\
\hline 10 & 1.5115 & 0.919 & 136.3 & 1.903 & 126.9 & 2.728 \\
\hline 11 & 1.2219 & 1.046 & 113.0 & 2.501 & 134.4 & 3.160 \\
\hline
\end{tabular}

Power-Law Fit

Unloading Compliance

Coeff. C : $102 \mathrm{~kJ} / \mathrm{m}^{2}$

DC Potential Method

Coeff. C $\quad: 97 \mathrm{~kJ} / \mathrm{m}^{2}$
$\mathrm{J}=\mathrm{C}(\Delta \mathrm{a})^{\mathrm{n}}$

$\mathrm{J}_{\mathrm{Ic}} \quad: 51 \mathrm{~kJ} / \mathrm{m}^{2} \quad$ (5 Data)

Exponent n : 0.46

$\mathrm{J}_{\mathrm{Ic}} \quad: 61 \mathrm{~kJ} / \mathrm{m}^{2}$

Exponent $n: 0.30$
Fit Coeff. R : 0.989

(5 Data)

Fit Coeff. R : 0.995 


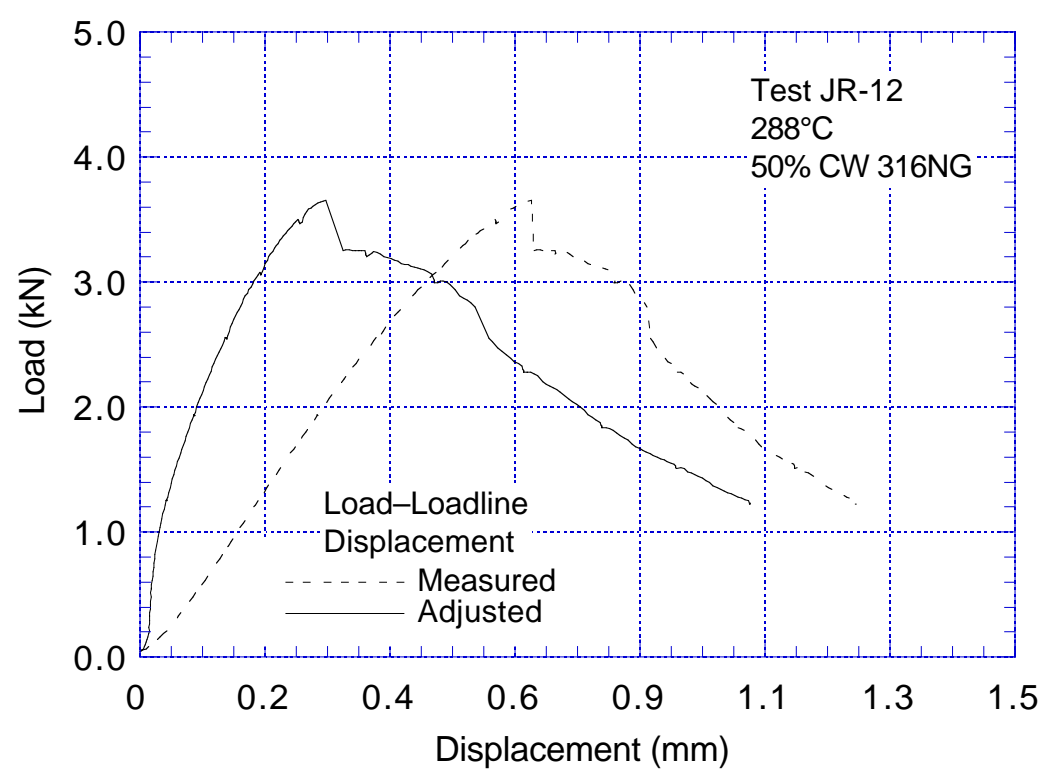

Figure A-6.1. Load-vs.-loadline displacement curve for specimen 184-38 of $50 \%$ cold-worked Type $316 \mathrm{NG}$ SS tested at $288^{\circ} \mathrm{C}$

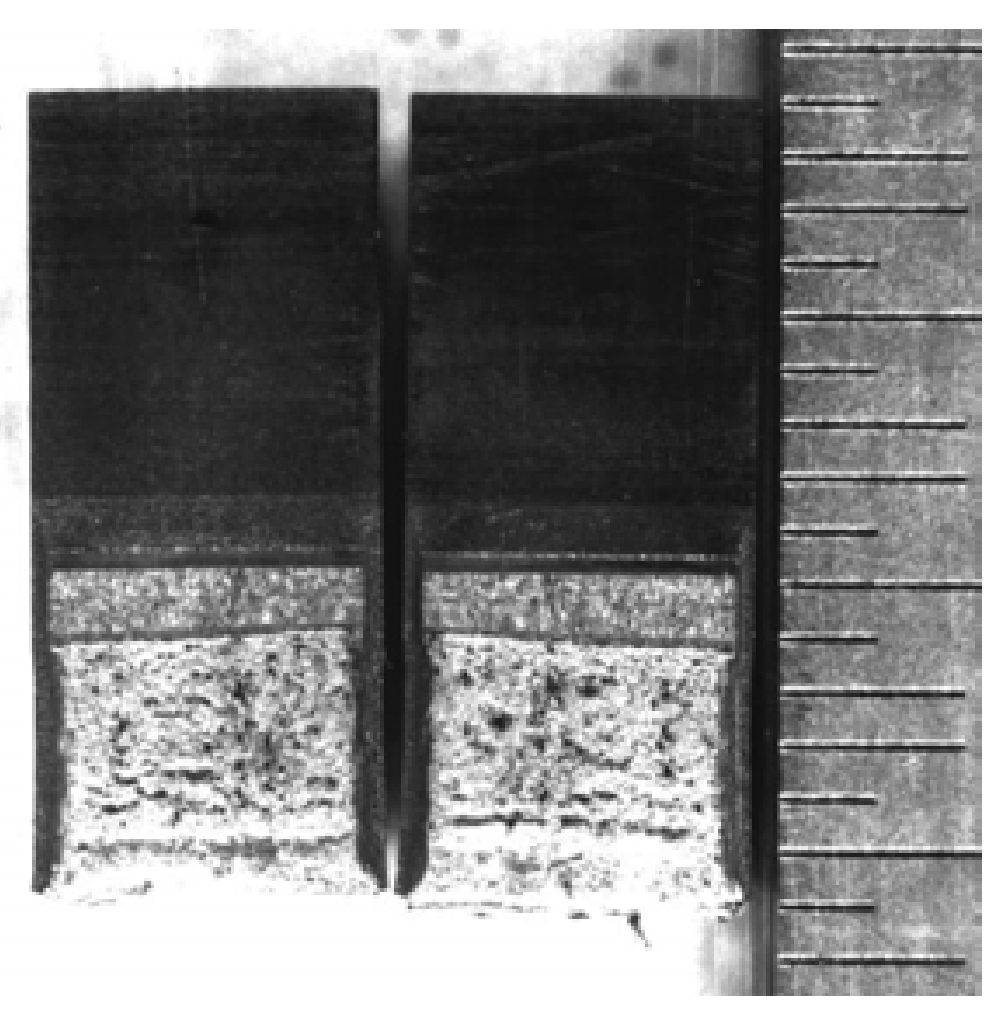

Figure A-6.2. Fracture surface of specimen $184-38$ tested at $288^{\circ} \mathrm{C}$ 
Table A-7. Test data for specimen $184-40$ of $50 \%$ cold-worked Type $316 N G$ SS tested at $288^{\circ} \mathrm{C}$

$\begin{array}{llll}\text { Test Number } & : \text { JR-19 } & \text { Test Temp. } & : 288^{\circ} \mathrm{C} \\ \text { Material Type } & : 50 \% \text { CW 316NG SS } & \text { Heat Number } & : 18474 \\ \text { Aging Temp. } & :- & \text { Aging Time } & :- \\ \text { Irradiation Temp. } & :- & \text { Fluence } & :- \\ \text { Thickness } & : 6.528 \mathrm{~mm} & \text { Net Thickness } & : 5.829 \mathrm{~mm} \\ \text { Width } & : 12.024 \mathrm{~mm} & \text { Flow Stress } & : 861.0 \mathrm{MPa} \\ \text { Modulus E } & : 175 \mathrm{GPa} & & \\ \text { Initial Crack } & : 7.35 \mathrm{~mm} & \text { Init. a/W } & : 0.61 \text { (Measured) } \\ \text { Final Crack } & : 10.28 \mathrm{~mm} & \text { Final a/W } & : 0.86 \text { (Measured) } \\ \text { Final Crack } & : 10.01 \mathrm{~mm} & \text { Final a/W } & : 0.82 \text { (Compliance) }\end{array}$

\begin{tabular}{|c|c|c|c|c|c|c|}
\hline \multirow[b]{2}{*}{ No. } & \multirow{2}{*}{$\begin{array}{c}\text { Load } \\
(\mathrm{kN})\end{array}$} & \multirow{2}{*}{$\begin{array}{l}\text { Deflection } \\
(\mathrm{mm})\end{array}$} & \multicolumn{2}{|c|}{ Unloading Compliance } & \multicolumn{2}{|c|}{ DC Potential Method } \\
\hline & & & $\mathrm{J}\left(\mathrm{kJ} / \mathrm{m}^{2}\right)$ & $\Delta \mathrm{a}(\mathrm{mm})$ & $\mathrm{J}\left(\mathrm{kJ} / \mathrm{m}^{2}\right)$ & $\Delta \mathrm{a}(\mathrm{mm})$ \\
\hline 0 & 0.0894 & 0.000 & & & & \\
\hline 1 & 1.2295 & 0.083 & 4.2 & 0.407 & 4.3 & 0.001 \\
\hline 2 & 1.8900 & 0.126 & 13.1 & 0.177 & 10.0 & 0.004 \\
\hline 3 & 2.5012 & 0.174 & 18.7 & 0.099 & 19.0 & 0.005 \\
\hline 4 & 3.0493 & 0.230 & 32.2 & 0.135 & 31.9 & 0.009 \\
\hline 5 & 3.4621 & 0.304 & 52.6 & 0.148 & 52.3 & 0.015 \\
\hline 6 & 3.2699 & 0.419 & 79.9 & 0.481 & 86.3 & 0.373 \\
\hline 7 & 2.6147 & 0.568 & 99.7 & 1.030 & 110.4 & 0.997 \\
\hline 8 & 2.3976 & 0.634 & 103.4 & 1.228 & 105.4 & 1.229 \\
\hline 9 & 1.9777 & 0.715 & 109.2 & 1.530 & 113.1 & 1.574 \\
\hline 10 & 1.6716 & 0.788 & 114.2 & 1.699 & 112.9 & 1.850 \\
\hline 11 & 1.5275 & 0.850 & 116.5 & 1.890 & 112.8 & 2.051 \\
\hline 12 & 1.4056 & 0.910 & 116.5 & 2.098 & 115.3 & 2.261 \\
\hline 13 & 1.2873 & 0.971 & 118.4 & 2.238 & 116.1 & 2.436 \\
\hline 14 & 1.1210 & 1.037 & 118.8 & 2.420 & 118.1 & 2.642 \\
\hline 15 & 1.0453 & 1.094 & 119.1 & 2.547 & 116.2 & 2.794 \\
\hline 16 & 0.9715 & 1.152 & 120.2 & 2.666 & 117.6 & 2.939 \\
\hline
\end{tabular}

Power-Law Fit

Unloading Compliance

Coeff. C : $96 \mathrm{~kJ} / \mathrm{m}^{2}$

DC Potential Method

Coeff. C $\quad: 104 \mathrm{~kJ} / \mathrm{m}^{2}$
$\mathrm{J}=\mathrm{C}(\Delta \mathrm{a})^{\mathrm{n}}$

$\mathrm{J}_{\text {Ic }} \quad: 61 \mathrm{~kJ} / \mathrm{m}^{2}$

Exponent $\mathrm{n}: 0.30$

J $\quad: 81 \mathrm{~kJ} / \mathrm{m}^{2}$

Exponent n : 0.17
(8 Data)

Fit Coeff. R : 0.993

(8 Data)

Fit Coeff. R : 0.989 


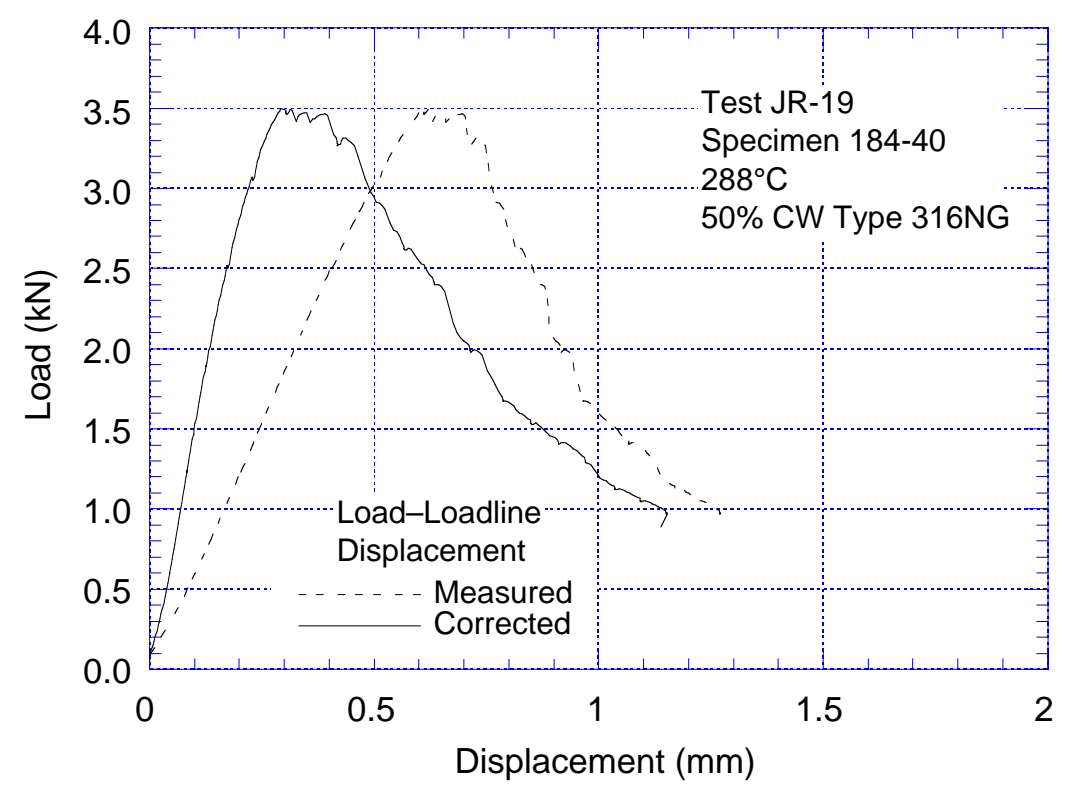

Figure A-7.1. Load-vs.-loadline displacement curve for specimen 184-40 of $50 \%$ cold-worked Type $316 \mathrm{NG}$ SS tested at $288^{\circ} \mathrm{C}$

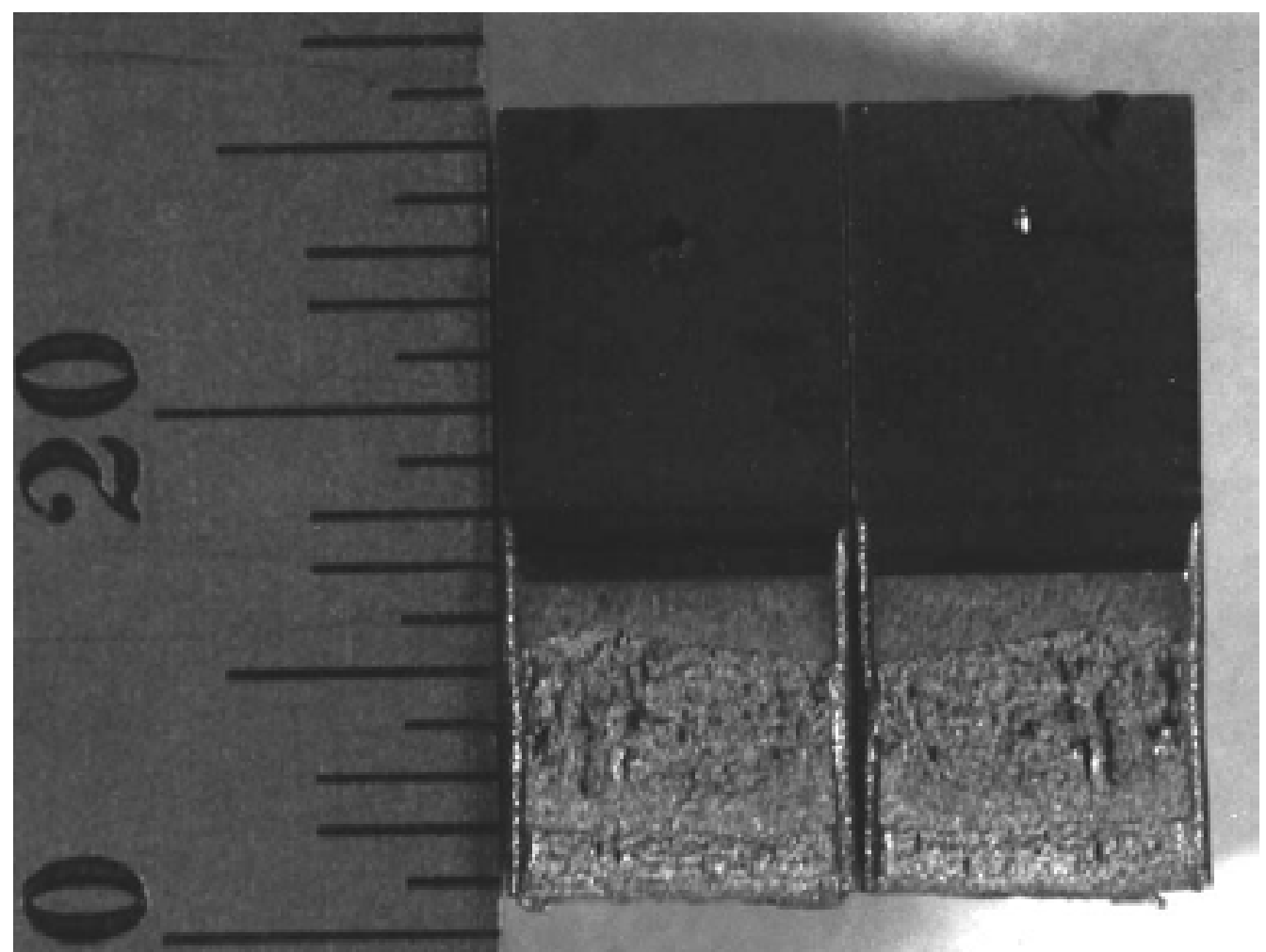

Figure A-7.2. Fracture surface of specimen $184-40$ tested at $288^{\circ} \mathrm{C}$ 
Table A-8. Test data for specimen C19-D of nonirradiated Type 304 SS tested at $288^{\circ} \mathrm{C}$

$\begin{array}{ll}\text { Test Number } & : \text { JR-27 } \\ \text { Material Type } & : \text { Type 304 SS } \\ \text { Aging Temp. } & :- \\ \text { Irradiation Temp. } & :- \\ \text { Thickness } & : 6.480 \mathrm{~mm} \\ \text { Width } & : 12.000 \mathrm{~mm} \\ \text { Modulus E } & : 175 \mathrm{GPa} \\ \text { Initial Crack } & : 7.28 \mathrm{~mm} \\ \text { Final Crack } & : 7.63 \mathrm{~mm} \\ \text { Final Crack } & : 7.70 \mathrm{~mm}\end{array}$

$\begin{array}{ll}\text { Test Temp. } & : 288^{\circ} \mathrm{C} \\ \text { Heat Number } & : \mathrm{C} 19 \\ \text { Aging Time } & :- \\ \text { Fluence } & :- \\ \text { Net Thickness } & : 5.890 \mathrm{~mm} \\ \text { Flow Stress } & : 339.5 \mathrm{MPa} \\ & \\ \text { Init. a/W } & : 0.61 \text { (Measured) } \\ \text { Final a/W } & : 0.64 \text { (Measured) } \\ \text { Final a/W } & : 0.64 \text { (Compliance) }\end{array}$

\begin{tabular}{|c|c|c|c|c|c|c|}
\hline \multirow[b]{2}{*}{ No. } & \multirow{2}{*}{$\begin{array}{c}\text { Load } \\
(\mathrm{kN})\end{array}$} & \multirow{2}{*}{$\begin{array}{l}\text { Deflection } \\
\text { (mm) }\end{array}$} & \multicolumn{2}{|c|}{ Unloading Compliance } & \multicolumn{2}{|c|}{ DC Potential Method } \\
\hline & & & $\mathrm{J}\left(\mathrm{kJ} / \mathrm{m}^{2}\right)$ & $\Delta \mathrm{a}(\mathrm{mm})$ & $\mathrm{J}\left(\mathrm{kJ} / \mathrm{m}^{2}\right)$ & $\Delta \mathrm{a}(\mathrm{mm})$ \\
\hline 0 & 0.089 & 0.000 & & & & \\
\hline 1 & 1.214 & 0.247 & 21.8 & -0.001 & 21.8 & 0.016 \\
\hline 2 & 1.279 & 0.342 & 31.5 & -0.027 & 31.2 & 0.023 \\
\hline 3 & 1.346 & 0.435 & 40.3 & 0.056 & 40.9 & 0.030 \\
\hline 4 & 1.407 & 0.582 & 56.5 & 0.070 & 57.0 & 0.042 \\
\hline 5 & 1.515 & 0.774 & 80.0 & 0.033 & 79.3 & 0.059 \\
\hline 6 & 1.607 & 0.969 & 102.8 & 0.087 & 103.2 & 0.076 \\
\hline 7 & 1.674 & 1.166 & 125.6 & 0.181 & 128.6 & 0.092 \\
\hline 8 & 1.790 & 1.562 & 183.4 & 0.172 & 182.4 & 0.135 \\
\hline 9 & 1.852 & 1.761 & 210.0 & 0.232 & 210.9 & 0.155 \\
\hline 10 & 1.931 & 1.956 & 247.1 & 0.134 & 239.4 & 0.182 \\
\hline 11 & 2.025 & 2.355 & 300.5 & 0.254 & 301.1 & 0.221 \\
\hline 12 & 2.153 & 2.852 & 392.9 & 0.152 & 381.1 & 0.289 \\
\hline 13 & 2.221 & 3.150 & 433.5 & 0.253 & 432.1 & 0.319 \\
\hline 14 & 2.294 & 3.449 & 464.5 & 0.434 & 485.7 & 0.342 \\
\hline 15 & 2.439 & 4.045 & 587.5 & 0.418 & 590.0 & 0.433 \\
\hline 16 & 2.536 & 4.524 & & & 673.8 & 0.519 \\
\hline 17 & 2.617 & 5.046 & & & 765.5 & 0.625 \\
\hline 18 & 2.670 & 5.550 & & & 834.9 & 0.811 \\
\hline
\end{tabular}

Power-Law Fit

Unloading Compliance

Coeff. C : $765 \mathrm{~kJ} / \mathrm{m}^{2}$

DC Potential Method
$\mathrm{J}=\mathrm{C}(\Delta \mathrm{a})^{\mathrm{n}}$

$\mathrm{J}_{\text {Ic }} \quad: 695 \mathrm{~kJ} / \mathrm{m}^{2} \quad$ (9 Data)

Exponent $\mathrm{n}: 0.28 \quad$ Fit Coeff. $\mathrm{R}: 0.338$

(information could not be determined) 


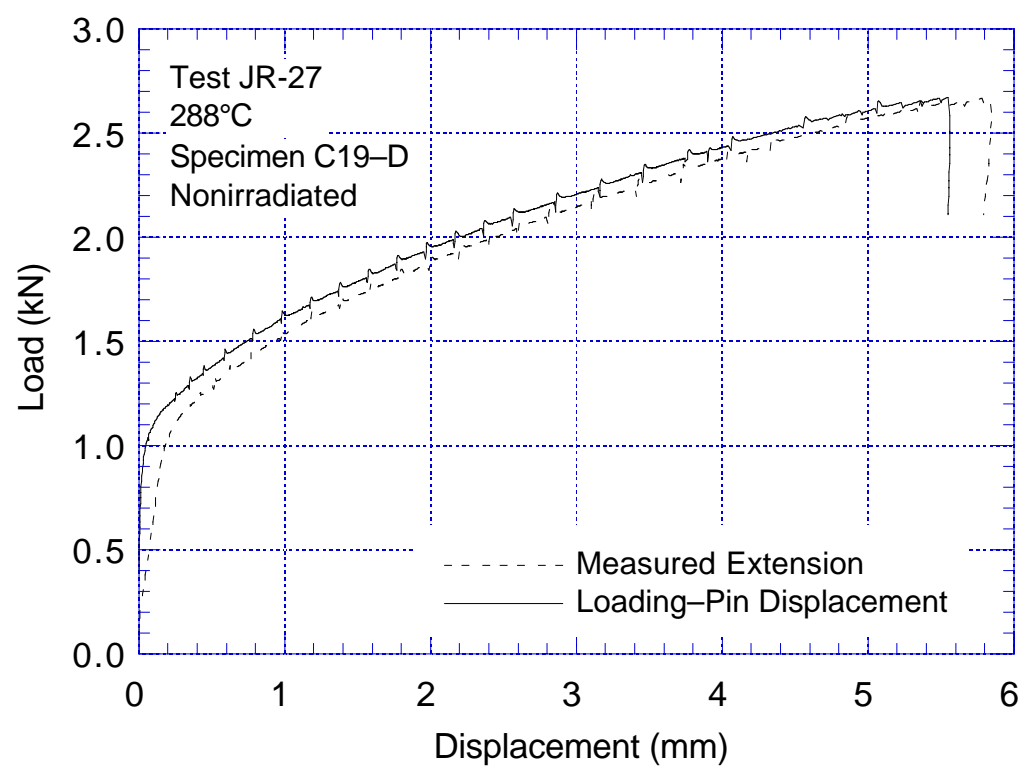

Figure A-8.1. Load-vs.-loadline displacement curve for specimen C19-D of nonirradiated Type 304 SS tested at $288^{\circ} \mathrm{C}$

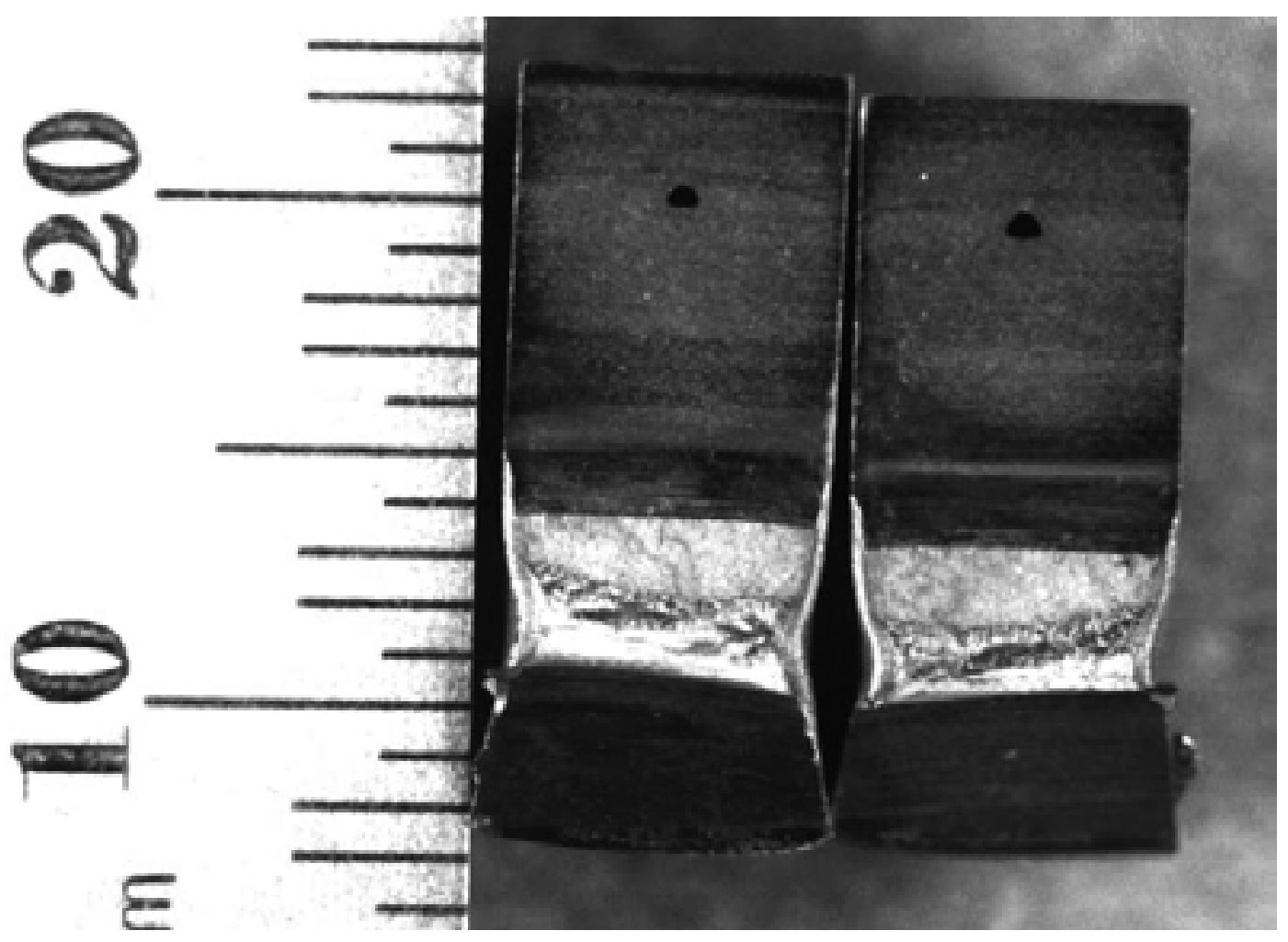

Figure A-8.2. Fracture surface of specimen C19-D tested at $288^{\circ} \mathrm{C}$ 
Table A-9. Test data for specimen C16-C of nonirradiated Type 316 SS tested at $288^{\circ} \mathrm{C}$

$\begin{array}{ll}\text { Test Number } & : \text { JR-31 } \\ \text { Material Type } & : \text { Type 316 SS } \\ \text { Aging Temp. } & :- \\ \text { Irradiation Temp. } & :- \\ \text { Thickness } & : 6.500 \mathrm{~mm} \\ \text { Width } & : 11.990 \mathrm{~mm} \\ \text { Modulus E } & : 175 \mathrm{GPa} \\ \text { Initial Crack } & : 7.30 \mathrm{~mm} \\ \text { Final Crack } & : 7.96 \mathrm{~mm} \\ \text { Final Crack } & : 7.65 \mathrm{~mm}\end{array}$

$\begin{array}{ll}\text { Test Temp. } & : 288^{\circ} \mathrm{C} \\ \text { Heat Number } & : \mathrm{C} 16 \\ \text { Aging Time } & :- \\ \text { Fluence } & :- \\ \text { Net Thickness } & : 5.810 \mathrm{~mm} \\ \text { Flow Stress } & : 336.0 \mathrm{MPa} \text { (estimated) } \\ & : 0.61 \text { (Measured) } \\ \text { Init. a/W } & : 0.66 \text { (Measured) } \\ \text { Final a/W } & : 0.64 \text { (Compliance) }\end{array}$

\begin{tabular}{|c|c|c|c|c|c|c|}
\hline \multirow[b]{2}{*}{ No. } & \multirow{2}{*}{$\begin{array}{c}\text { Load } \\
(\mathrm{kN})\end{array}$} & \multirow{2}{*}{$\begin{array}{l}\text { Deflection } \\
\text { (mm) }\end{array}$} & \multicolumn{2}{|c|}{ Unloading Compliance } & \multicolumn{2}{|c|}{ DC Potential Method } \\
\hline & & & $\mathrm{J}\left(\mathrm{kJ} / \mathrm{m}^{2}\right)$ & $\Delta \mathrm{a}(\mathrm{mm})$ & $\mathrm{J}\left(\mathrm{kJ} / \mathrm{m}^{2}\right)$ & $\Delta \mathrm{a}(\mathrm{mm})$ \\
\hline 0 & 0.065 & 0.000 & & & 0.0 & 0.000 \\
\hline 1 & 1.207 & 0.208 & 18.9 & -0.002 & 19.0 & 0.014 \\
\hline 2 & 1.293 & 0.412 & 40.2 & -0.064 & 39.5 & 0.030 \\
\hline 3 & 1.370 & 0.618 & 60.7 & 0.023 & 61.5 & 0.045 \\
\hline 4 & 1.426 & 0.826 & 82.5 & 0.103 & 84.7 & 0.061 \\
\hline 5 & 1.492 & 1.023 & 108.6 & 0.041 & 107.8 & 0.081 \\
\hline 6 & 1.555 & 1.220 & 129.2 & 0.146 & 132.0 & 0.096 \\
\hline 7 & 1.620 & 1.417 & 152.1 & 0.219 & 157.0 & 0.113 \\
\hline 8 & 1.674 & 1.615 & 178.7 & 0.236 & 182.9 & 0.133 \\
\hline 9 & 1.784 & 2.012 & 251.4 & 0.077 & 236.3 & 0.187 \\
\hline 10 & 1.831 & 2.211 & 278.6 & 0.095 & 264.8 & 0.207 \\
\hline 11 & 1.877 & 2.410 & 310.1 & 0.082 & 293.7 & 0.231 \\
\hline 12 & 1.925 & 2.609 & 338.6 & 0.112 & 323.6 & 0.252 \\
\hline 13 & 1.977 & 2.808 & 373.7 & 0.081 & 353.6 & 0.278 \\
\hline 14 & 2.023 & 3.007 & 413.8 & 0.015 & 384.0 & 0.308 \\
\hline 15 & 2.060 & 3.207 & 439.0 & 0.083 & 416.3 & 0.327 \\
\hline 16 & 2.100 & 3.407 & 469.7 & 0.108 & 448.6 & 0.349 \\
\hline 17 & 2.140 & 3.607 & 503.6 & 0.114 & 481.1 & 0.375 \\
\hline 18 & 2.180 & 3.807 & 520.0 & 0.243 & 515.9 & 0.387 \\
\hline 19 & 2.219 & 4.007 & 555.5 & 0.249 & 549.1 & 0.413 \\
\hline 20 & 2.259 & 4.207 & 601.8 & 0.197 & 581.4 & 0.448 \\
\hline 21 & 2.298 & 4.406 & 632.6 & 0.239 & 616.3 & 0.471 \\
\hline 22 & 2.330 & 4.607 & 646.5 & 0.371 & 654.1 & 0.481 \\
\hline 23 & 2.359 & 4.808 & 689.0 & 0.356 & 688.2 & 0.513 \\
\hline
\end{tabular}

Power-Law Fit $\quad \mathrm{J}=\mathrm{C}(\Delta \mathrm{a})^{\mathrm{n}}$

(information could not be determined) 


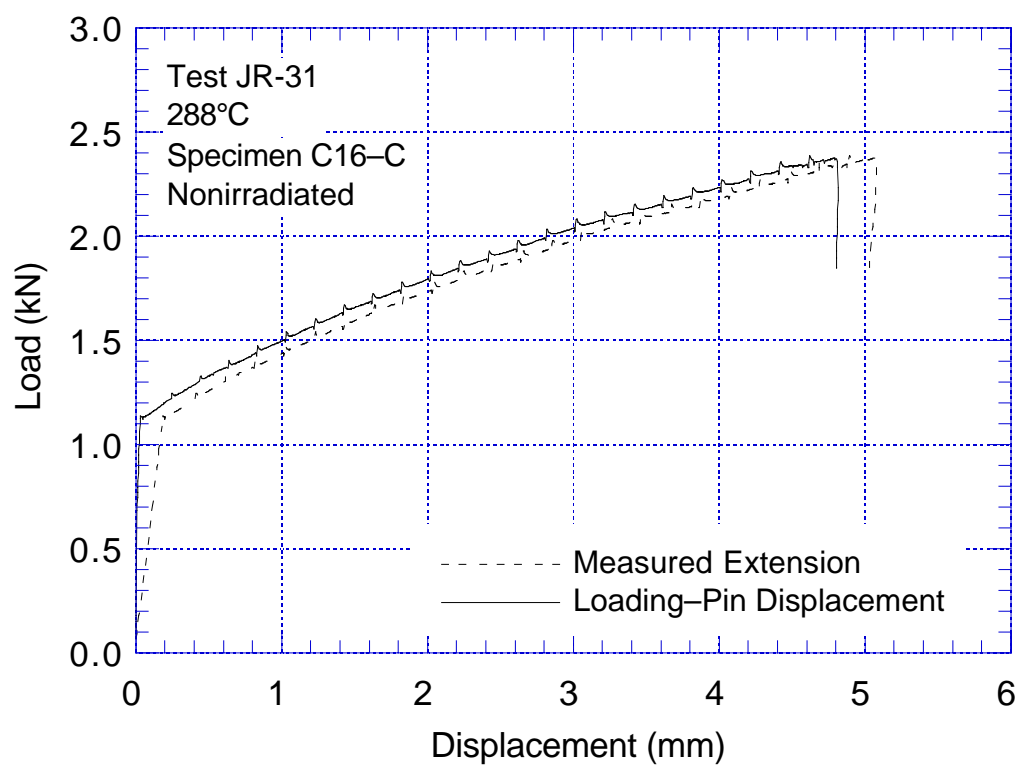

Figure A-9.1. Load-vs.-loadline displacement curve for specimen C16-C of nonirradiated Type $316 \mathrm{SS}$ tested at $288^{\circ} \mathrm{C}$

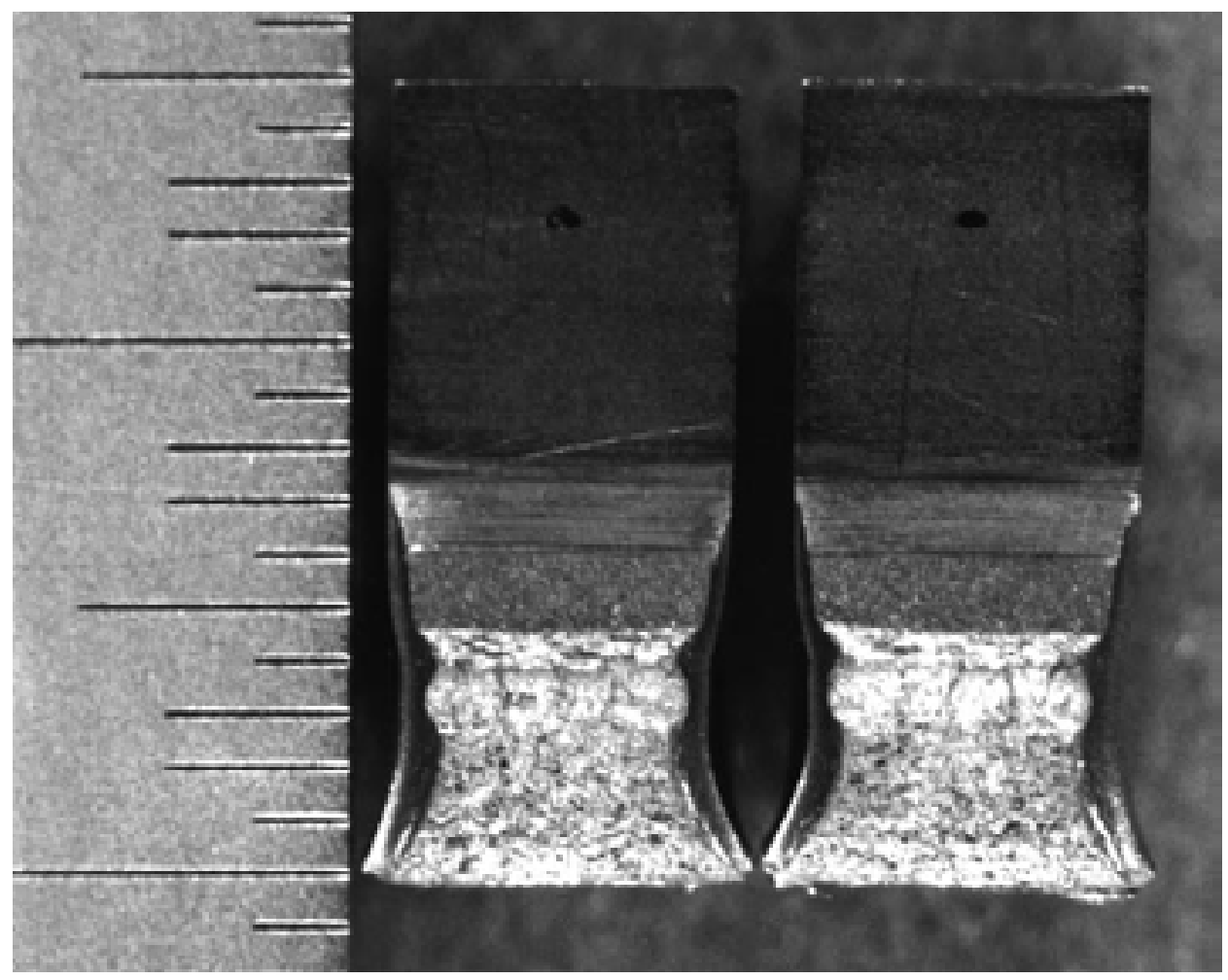

Figure A-9.2. Fracture surface of specimen $\mathrm{C} 16-\mathrm{C}$ tested at $288^{\circ} \mathrm{C}$ 
Table A-10. Test data for specimen C16-D of nonirradiated Type 316 SS tested at $288^{\circ} \mathrm{C}$

$\begin{array}{ll}\text { Test Number } & : \text { JR-28 } \\ \text { Material Type } & : \text { Type 316 SS } \\ \text { Aging Temp. } & :- \\ \text { Irradiation Temp. } & :- \\ \text { Thickness } & : 6.470 \mathrm{~mm} \\ \text { Width } & : 11.980 \mathrm{~mm} \\ \text { Modulus E } & : 175 \mathrm{GPa} \\ \text { Initial Crack } & : 7.41 \mathrm{~mm} \\ \text { Final Crack } & : 7.83 \mathrm{~mm} \\ \text { Final Crack } & : 7.60 \mathrm{~mm}\end{array}$

$\begin{array}{ll}\text { Test Temp. } & : 288^{\circ} \mathrm{C} \\ \text { Heat Number } & : \mathrm{C} 16 \\ \text { Aging Time } & :- \\ \text { Fluence } & :- \\ \text { Net Thickness } & : 5.90 \mathrm{~mm} \\ \text { Flow Stress } & : 336.0 \mathrm{MPa} \text { (estimated) } \\ & : 0.62 \text { (Measured) } \\ \text { Init. a/W } & : 0.65 \text { (Measured) } \\ \text { Final a/W } & : 0.63 \text { (Compliance) }\end{array}$

\begin{tabular}{|c|c|c|c|c|c|c|}
\hline \multirow[b]{2}{*}{ No. } & \multirow{2}{*}{$\begin{array}{c}\text { Load } \\
(\mathrm{kN})\end{array}$} & \multirow{2}{*}{$\begin{array}{l}\text { Deflection } \\
\text { (mm) }\end{array}$} & \multicolumn{2}{|c|}{ Unloading Compliance } & \multicolumn{2}{|c|}{ DC Potential Method } \\
\hline & & & $\mathrm{J}\left(\mathrm{kJ} / \mathrm{m}^{2}\right)$ & $\Delta \mathrm{a}(\mathrm{mm})$ & $\mathrm{J}\left(\mathrm{kJ} / \mathrm{m}^{2}\right)$ & $\Delta \mathrm{a}(\mathrm{mm})$ \\
\hline 0 & 0.088 & 0.000 & & & 0.0 & 0.000 \\
\hline 1 & 1.218 & 0.247 & 22.5 & 0.059 & 23.0 & 0.017 \\
\hline 2 & 1.304 & 0.441 & 43.5 & 0.007 & 42.9 & 0.032 \\
\hline 3 & 1.373 & 0.637 & 63.8 & 0.072 & 64.1 & 0.047 \\
\hline 4 & 1.439 & 0.834 & 85.4 & 0.129 & 86.5 & 0.064 \\
\hline 5 & 1.501 & 1.031 & 109.2 & 0.140 & 109.9 & 0.081 \\
\hline 6 & 1.567 & 1.228 & 138.6 & 0.026 & 134.1 & 0.103 \\
\hline 7 & 1.621 & 1.426 & 170.1 & -0.096 & 159.3 & 0.127 \\
\hline 8 & 1.672 & 1.625 & 192.1 & -0.014 & 185.7 & 0.143 \\
\hline 9 & 1.725 & 1.823 & 204.8 & 0.230 & 213.3 & 0.152 \\
\hline 10 & 1.772 & 2.023 & 230.1 & 0.287 & 241.3 & 0.171 \\
\hline 11 & 1.818 & 2.222 & 260.1 & 0.295 & 269.7 & 0.194 \\
\hline 12 & 1.865 & 2.421 & 310.7 & 0.068 & 297.6 & 0.231 \\
\hline 13 & 1.908 & 2.621 & 332.8 & 0.169 & 327.7 & 0.248 \\
\hline 14 & 1.949 & 2.820 & 368.4 & 0.134 & 357.8 & 0.274 \\
\hline 15 & 1.982 & 3.020 & 400.4 & 0.141 & 388.8 & 0.298 \\
\hline 16 & 2.019 & 3.221 & 428.9 & 0.182 & 420.6 & 0.319 \\
\hline 17 & 2.055 & 3.420 & 467.3 & 0.148 & 452.3 & 0.348 \\
\hline 18 & 2.088 & 3.621 & 495.4 & 0.195 & 484.8 & 0.369 \\
\hline
\end{tabular}

Power-Law Fit $J=C(\Delta a)^{n}$

(information could not be determined) 


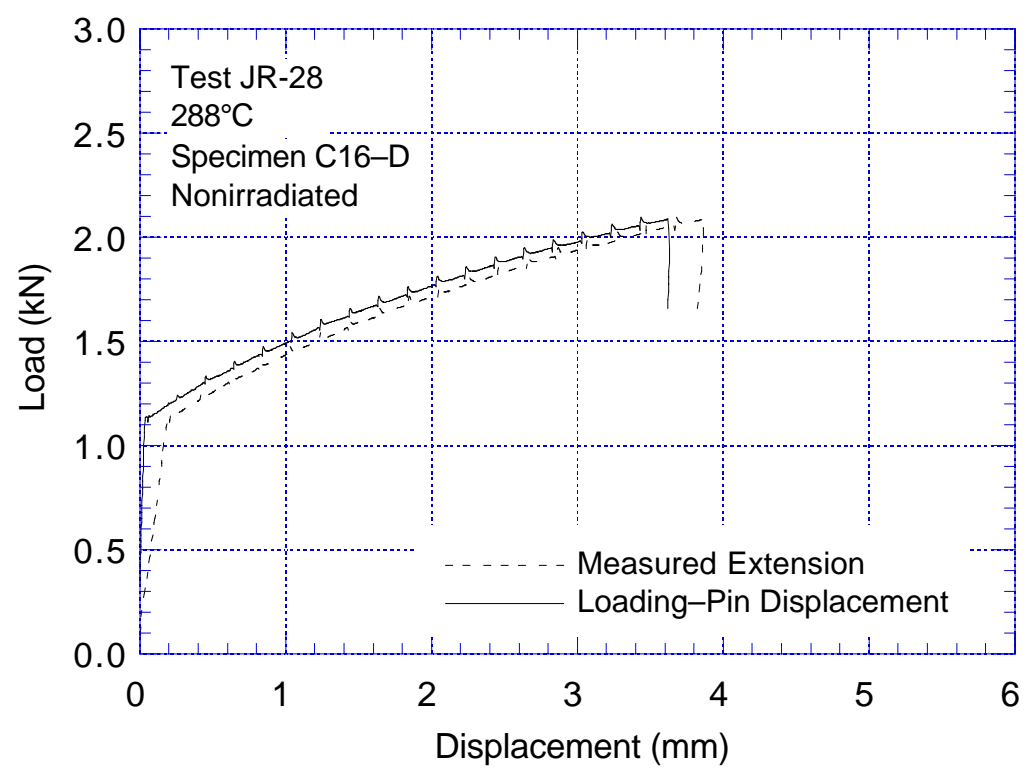

Figure A-10.1. Load-vs.-loadline displacement curve for specimen C16-D of nonirradiated Type 316 SS tested at $288^{\circ} \mathrm{C}$

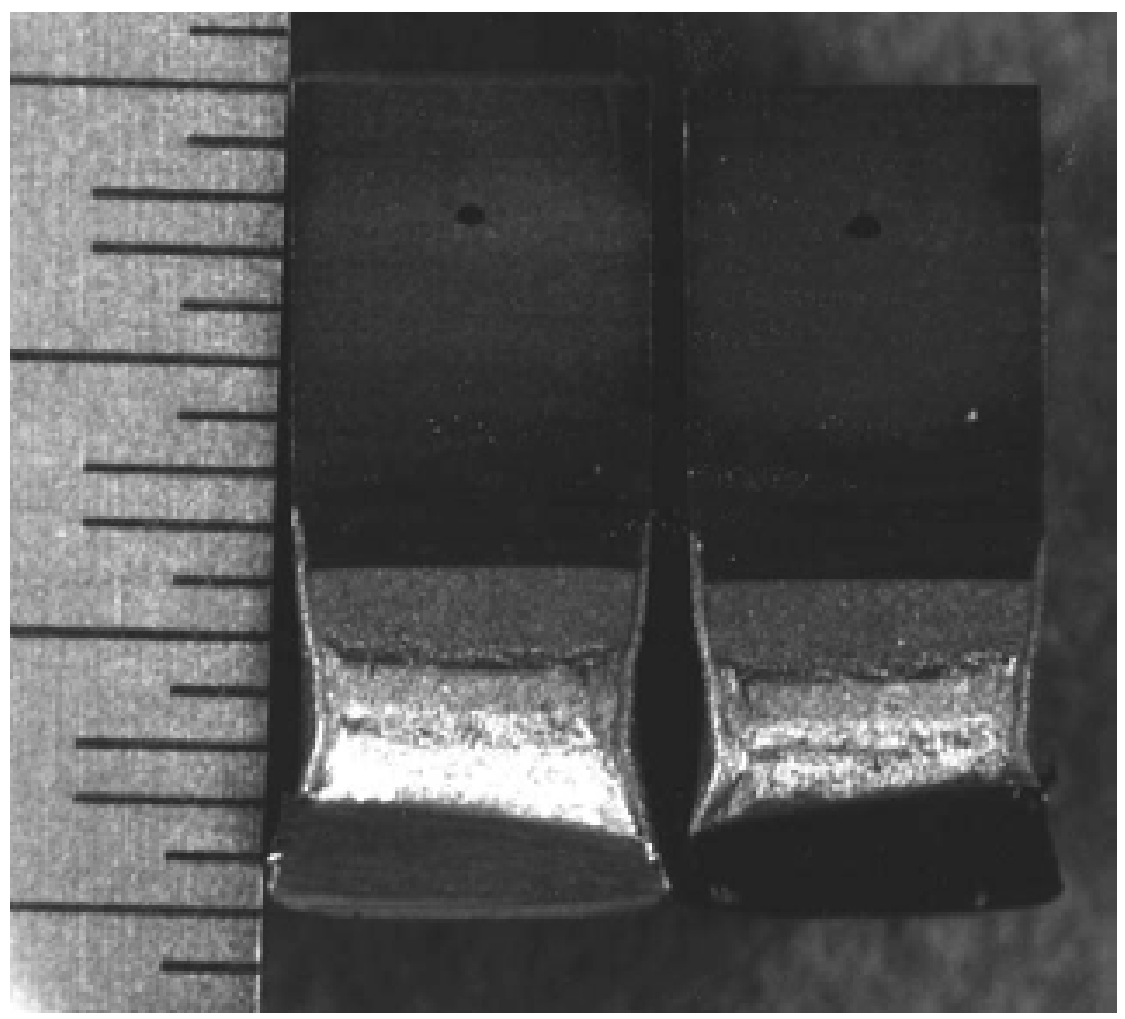

Figure A-10.2. Fracture surface of specimen $C 16-D$ tested at $288^{\circ} \mathrm{C}$ 
Table A-11. Test data for specimen L20-D of nonirradiated Type 304 SS tested at $288^{\circ} \mathrm{C}$

$\begin{array}{llll}\text { Test Number } & : \text { JR-29 } & \text { Test Temp. } & : 288^{\circ} \mathrm{C} \\ \text { Material Type } & : \text { Type 304L SS (HP) } & \text { Heat Number } & : \text { L20 } \\ \text { Aging Temp. } & :- & \text { Aging Time } & :- \\ \text { Irradiation Temp. } & :- & \text { Fluence } & :- \\ \text { Thickness } & : 6.50 \mathrm{~mm} & \text { Net Thickness } & : 5.89 \mathrm{~mm} \\ \text { Width } & : 12.00 \mathrm{~mm} & \text { Flow Stress } & : 307.0 \mathrm{MPa} \text { (estimated) } \\ \text { Modulus E } & : 175 \mathrm{GPa} & & \\ \text { Initial Crack } & : 7.22 \mathrm{~mm} & \text { Init. a/W } & : 0.60 \text { (Measured) } \\ \text { Final Crack } & : 9.52 \mathrm{~mm} & \text { Final a/W } & : 0.79 \text { (Measured) } \\ \text { Final Crack } & : 8.84 \mathrm{~mm} & \text { Final a/W } & : 0.74 \text { (Compliance) }\end{array}$

\begin{tabular}{|c|c|c|c|c|c|c|}
\hline \multirow[b]{2}{*}{ No. } & \multirow{2}{*}{$\begin{array}{c}\text { Load } \\
(\mathrm{kN})\end{array}$} & \multirow{2}{*}{$\begin{array}{l}\text { Deflection } \\
(\mathrm{mm})\end{array}$} & \multicolumn{2}{|c|}{ Unloading Compliance } & \multicolumn{2}{|c|}{ DC Potential Method } \\
\hline & & & $\mathrm{J}\left(\mathrm{kJ} / \mathrm{m}^{2}\right)$ & $\Delta \mathrm{a}(\mathrm{mm})$ & $\mathrm{J}\left(\mathrm{kJ} / \mathrm{m}^{2}\right)$ & $\Delta \mathrm{a}(\mathrm{mm})$ \\
\hline 0 & 0.0000 & 0.000 & & & & \\
\hline 1 & 1.2384 & 0.028 & 3.3 & -0.704 & 3.4 & 0.003 \\
\hline 2 & 1.4995 & 0.103 & 8.4 & -0.481 & 11.4 & 0.007 \\
\hline 3 & 1.6414 & 0.190 & 17.4 & -0.170 & 22.1 & 0.014 \\
\hline 4 & 1.7179 & 0.285 & 28.9 & 0.082 & 33.0 & 0.024 \\
\hline 5 & 1.8211 & 0.581 & 78.1 & 0.072 & 74.0 & 0.143 \\
\hline 6 & 1.8264 & 0.682 & 88.5 & 0.184 & 86.6 & 0.232 \\
\hline 7 & 1.8069 & 0.786 & 102.8 & 0.204 & 98.4 & 0.366 \\
\hline 8 & 1.7975 & 0.888 & 117.5 & 0.209 & 110.0 & 0.473 \\
\hline 9 & 1.7949 & 0.991 & 125.9 & 0.397 & 121.8 & 0.576 \\
\hline 10 & 1.7917 & 1.092 & 138.0 & 0.460 & 134.0 & 0.659 \\
\hline 11 & 1.7704 & 1.196 & 153.0 & 0.473 & 146.4 & 0.748 \\
\hline 12 & 1.7468 & 1.300 & 169.2 & 0.460 & 158.1 & 0.843 \\
\hline 13 & 1.7148 & 1.405 & 175.8 & 0.635 & 169.6 & 0.940 \\
\hline 14 & 1.6761 & 1.510 & 192.7 & 0.600 & 180.3 & 1.044 \\
\hline 15 & 1.6365 & 1.615 & 203.1 & 0.686 & 190.0 & 1.153 \\
\hline 16 & 1.5991 & 1.720 & 212.3 & 0.774 & 199.3 & 1.263 \\
\hline 17 & 1.5627 & 1.825 & 224.8 & 0.808 & 208.5 & 1.363 \\
\hline 18 & 1.5440 & 1.929 & 225.6 & 0.999 & 217.8 & 1.455 \\
\hline 19 & 1.5088 & 2.033 & 240.6 & 0.990 & 227.2 & 1.544 \\
\hline 20 & 1.4684 & 2.139 & 243.0 & 1.150 & 235.9 & 1.641 \\
\hline 21 & 1.4354 & 2.244 & 253.0 & 1.200 & 243.8 & 1.737 \\
\hline 22 & 1.4021 & 2.349 & 266.8 & 1.211 & 252.5 & 1.815 \\
\hline 23 & 1.3652 & 2.454 & 272.8 & 1.306 & 260.8 & 1.902 \\
\hline 24 & 1.3260 & 2.559 & 283.3 & 1.344 & 267.3 & 2.000 \\
\hline 25 & 1.2886 & 2.665 & 293.3 & 1.386 & 272.9 & 2.098 \\
\hline 26 & 1.2517 & 2.770 & 289.9 & 1.550 & 278.1 & 2.194 \\
\hline 27 & 1.2104 & 2.876 & 294.9 & 1.626 & 281.8 & 2.302 \\
\hline
\end{tabular}

Power-Law Fit

Unloading Compliance

Coeff. C $\quad: 236 \mathrm{~kJ} / \mathrm{m}^{2}$

DC Potential Method

Coeff. C $\quad: 174 \mathrm{~kJ} / \mathrm{m}^{2}$
$\mathrm{J}=\mathrm{C}(\Delta \mathrm{a})^{\mathrm{n}}$

$\mathrm{J}_{\mathrm{Ic}} \quad: 119 \mathrm{~kJ} / \mathrm{m}^{2} \quad$ (19 Data)

Exponent $\mathrm{n}: 0.56$

J Ic $\quad: 78 \mathrm{~kJ} / \mathrm{m}^{2} \quad$ (21 Data)

Exponent $n: 0.60$
Fit Coeff. R : 0.948

Fit Coeff. $\mathrm{R}$ : 0.998 


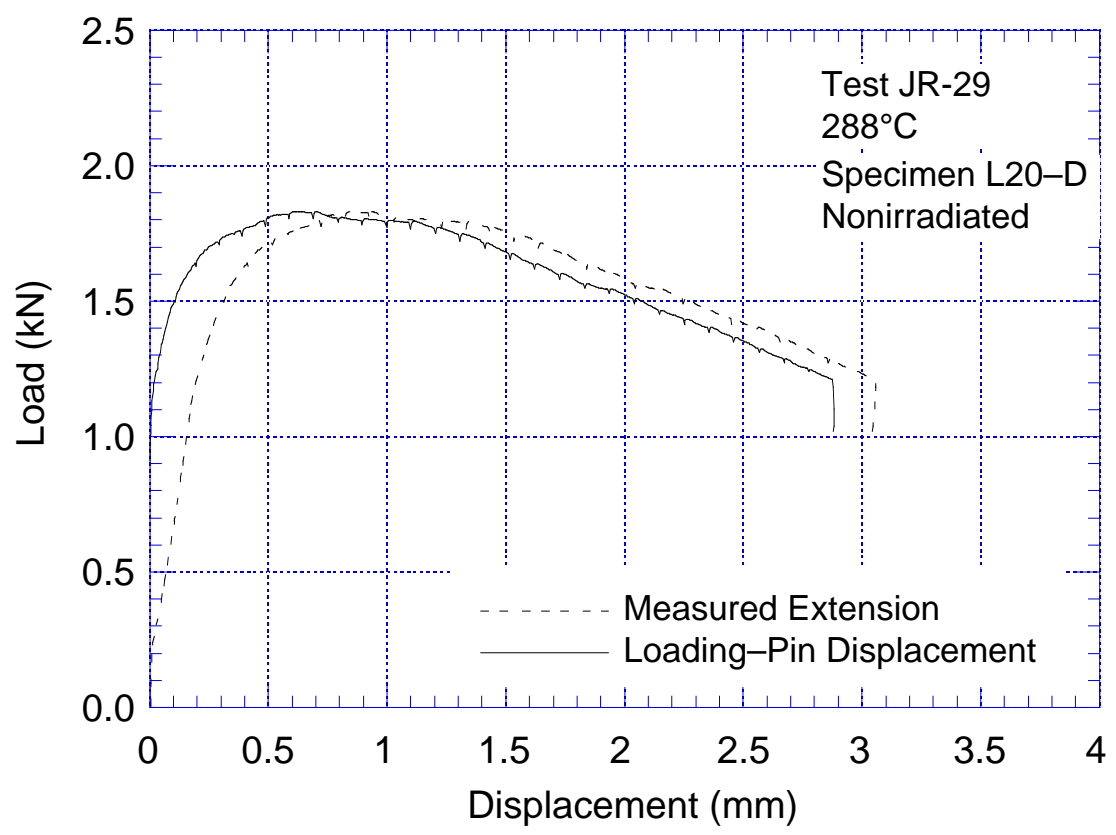

Figure A-11.1. Load-vs.-loadline displacement curve for specimen L20-D of nonirradiated Type $304 \mathrm{SS}$ tested at $288^{\circ} \mathrm{C}$

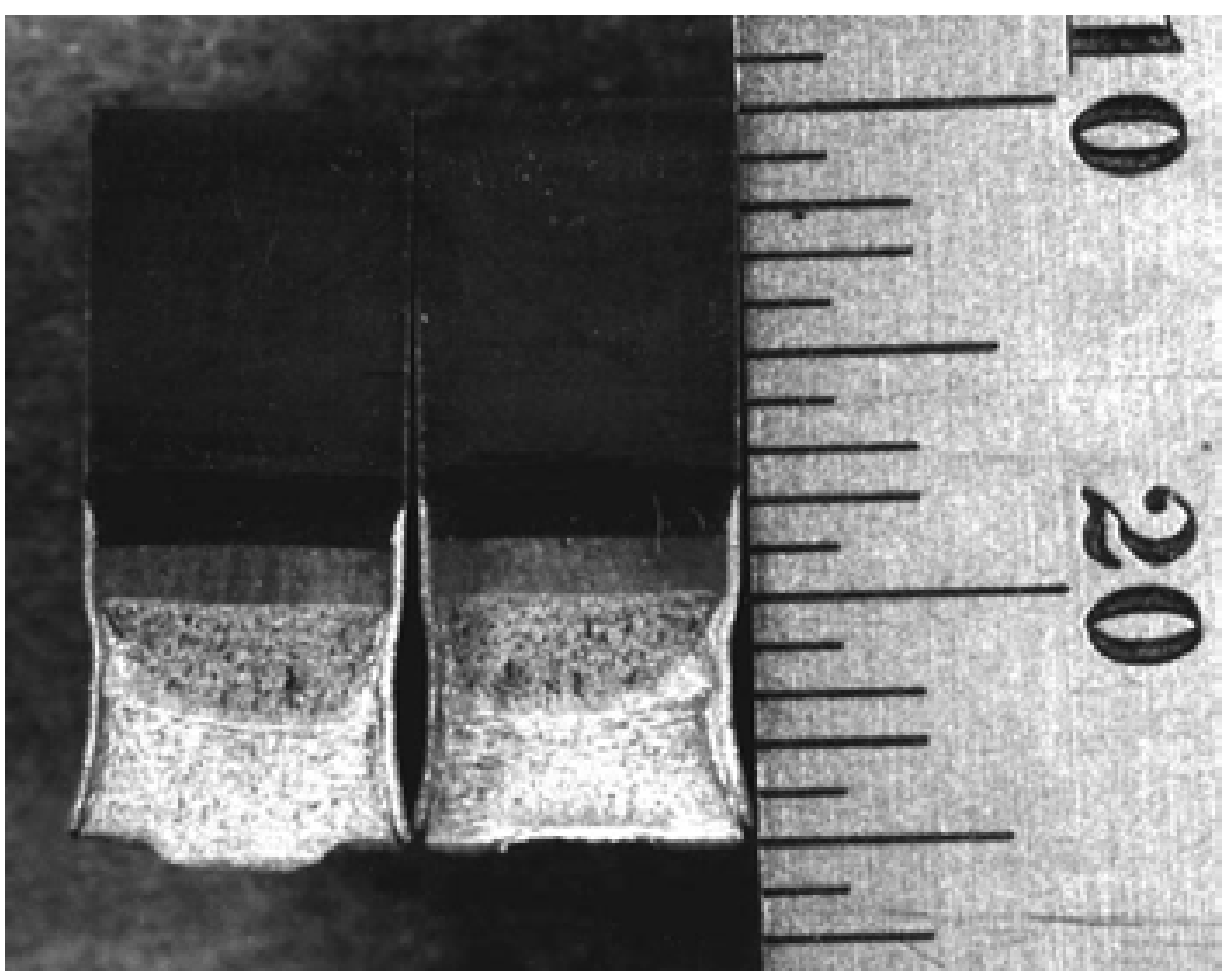

Figure A-11.2. Fracture surface of specimen L20-D tested at $288^{\circ} \mathrm{C}$ 
Table A-12. Test data for specimen L2-C of nonirradiated Type $304 \mathrm{SS}$ tested at $288^{\circ} \mathrm{C}$

$\begin{array}{ll}\text { Test Number } & : \text { JR-20 } \\ \text { Material Type } & : \text { Type 304 SS } \\ \text { Aging Temp. } & :- \\ \text { Irradiation Temp. } & :- \\ \text { Thickness } & : 6.51 \mathrm{~mm} \\ \text { Width } & : 11.98 \mathrm{~mm} \\ \text { Modulus E } & : 175 \mathrm{GPa} \\ \text { Initial Crack } & : 7.38 \mathrm{~mm} \\ \text { Final Crack } & : 9.17 \mathrm{~mm} \\ \text { Final Crack } & : 8.08 \mathrm{~mm}\end{array}$

$\begin{array}{ll}\text { Test Temp. } & : 288^{\circ} \mathrm{C} \\ \text { Heat Number } & : \text { L2 } \\ \text { Aging Time } & :- \\ \text { Fluence } & :- \\ \text { Net Thickness } & : 5.84 \mathrm{~mm} \\ \text { Flow Stress } & : 270.5 \mathrm{MPa} \\ & \\ \text { Init. a/W } & : 0.61 \text { (Measured) } \\ \text { Final a/W } & : 0.76 \text { (Measured) } \\ \text { Final a/W } & : 0.75 \text { (Compliance) }\end{array}$

\begin{tabular}{|c|c|c|c|c|c|c|}
\hline \multirow[b]{2}{*}{ No. } & \multirow{2}{*}{$\begin{array}{c}\text { Load } \\
(\mathrm{kN})\end{array}$} & \multirow{2}{*}{$\begin{array}{l}\text { Deflection } \\
(\mathrm{mm})\end{array}$} & \multicolumn{2}{|c|}{ Unloading Compliance } & \multicolumn{2}{|c|}{ DC Potential Method } \\
\hline & & & $\mathrm{J}\left(\mathrm{kJ} / \mathrm{m}^{2}\right)$ & $\Delta \mathrm{a}(\mathrm{mm})$ & $\mathrm{J}\left(\mathrm{kJ} / \mathrm{m}^{2}\right)$ & $\Delta \mathrm{a}(\mathrm{mm})$ \\
\hline 0 & 0.089 & 0.000 & & & & \\
\hline 1 & 1.300 & 0.080 & 6.5 & 0.237 & 6.5 & 0.006 \\
\hline 2 & 1.453 & 0.169 & 18.9 & 0.152 & 17.1 & 0.016 \\
\hline 3 & 1.529 & 0.265 & 30.2 & 0.155 & 29.3 & 0.028 \\
\hline 4 & 1.596 & 0.361 & 43.7 & 0.126 & 41.9 & 0.040 \\
\hline 5 & 1.648 & 0.459 & 58.7 & 0.041 & 55.2 & 0.054 \\
\hline 6 & 1.685 & 0.556 & 72.5 & 0.015 & 68.9 & 0.067 \\
\hline 7 & 1.717 & 0.656 & 87.4 & 0.027 & 83.2 & 0.080 \\
\hline 8 & 1.741 & 0.756 & 101.7 & 0.040 & 97.7 & 0.093 \\
\hline 9 & 1.754 & 0.857 & 117.1 & 0.027 & 112.4 & 0.107 \\
\hline 10 & 1.769 & 0.958 & 130.1 & 0.082 & 127.1 & 0.119 \\
\hline 11 & 1.774 & 1.059 & 144.7 & 0.101 & 142.1 & 0.132 \\
\hline 12 & 1.780 & 1.160 & 159.9 & 0.104 & 157.0 & 0.146 \\
\hline 13 & 1.775 & 1.275 & 176.7 & 0.120 & 171.1 & 0.234 \\
\hline 14 & 1.759 & 1.379 & 191.6 & 0.136 & 181.6 & 0.339 \\
\hline 15 & 1.734 & 1.482 & 203.5 & 0.200 & 192.3 & 0.432 \\
\hline 16 & 1.708 & 1.586 & 214.2 & 0.277 & 201.9 & 0.542 \\
\hline 17 & 1.692 & 1.688 & 227.3 & 0.310 & 211.0 & 0.651 \\
\hline 18 & 1.666 & 1.793 & 238.6 & 0.372 & 220.9 & 0.747 \\
\hline 19 & 1.619 & 1.898 & 243.2 & 0.518 & 230.0 & 0.850 \\
\hline 20 & 1.580 & 2.001 & 252.5 & 0.593 & 237.2 & 0.973 \\
\hline 21 & 1.544 & 2.105 & 260.8 & 0.676 & 244.9 & 1.075 \\
\hline 22 & 1.504 & 2.209 & 265.5 & 0.798 & 253.0 & 1.173 \\
\hline 23 & 1.461 & 2.315 & 275.3 & 0.859 & 259.4 & 1.289 \\
\hline 24 & 1.411 & 2.470 & 283.6 & 1.006 & 270.8 & 1.429 \\
\hline 25 & 1.353 & 2.627 & 292.9 & 1.132 & 280.0 & 1.577 \\
\hline 26 & 1.280 & 2.785 & 299.8 & 1.271 & 286.5 & 1.741 \\
\hline 27 & 1.219 & 2.942 & 304.8 & 1.417 & 292.3 & 1.893 \\
\hline
\end{tabular}

Power-Law Fit

Unloading Compliance

Coeff. C : $283 \mathrm{~kJ} / \mathrm{m}^{2}$

DC Potential Method

Coeff. C : $243 \mathrm{~kJ} / \mathrm{m}^{2}$
$\mathrm{J}=\mathrm{C}(\Delta \mathrm{a})^{\mathrm{n}}$

J $\quad: 237 \mathrm{~kJ} / \mathrm{m}^{2} \quad$ (13 Data)

Exponent $\mathrm{n}: 0.20$

J $\quad: 186 \mathrm{~kJ} / \mathrm{m}^{2} \quad$ (15 Data)

Exponent $\mathrm{n}: 0.27$
Fit Coeff. R : 0.988

Fit Coeff. $\mathrm{R}$ : 0.996 


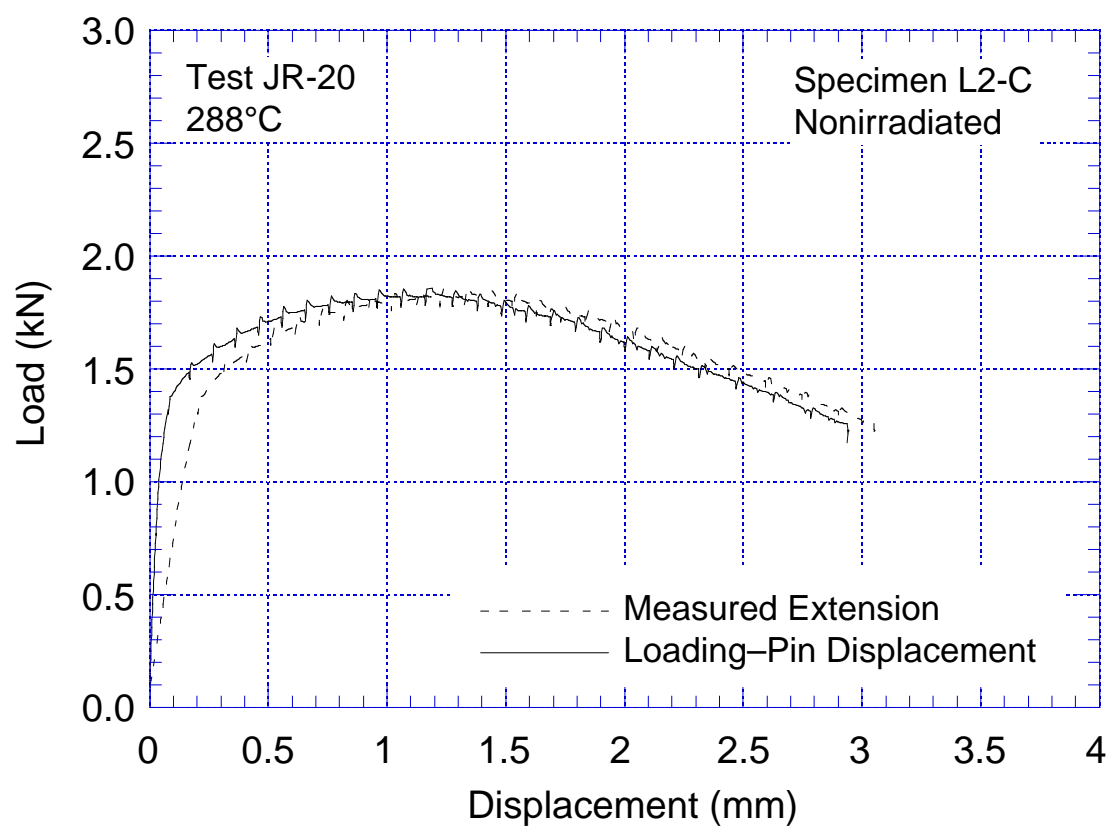

Figure A-12.1. Load-vs.-loadline displacement curve for specimen L2-C of nonirradiated Type $304 \mathrm{SS}$ tested at $288^{\circ} \mathrm{C}$

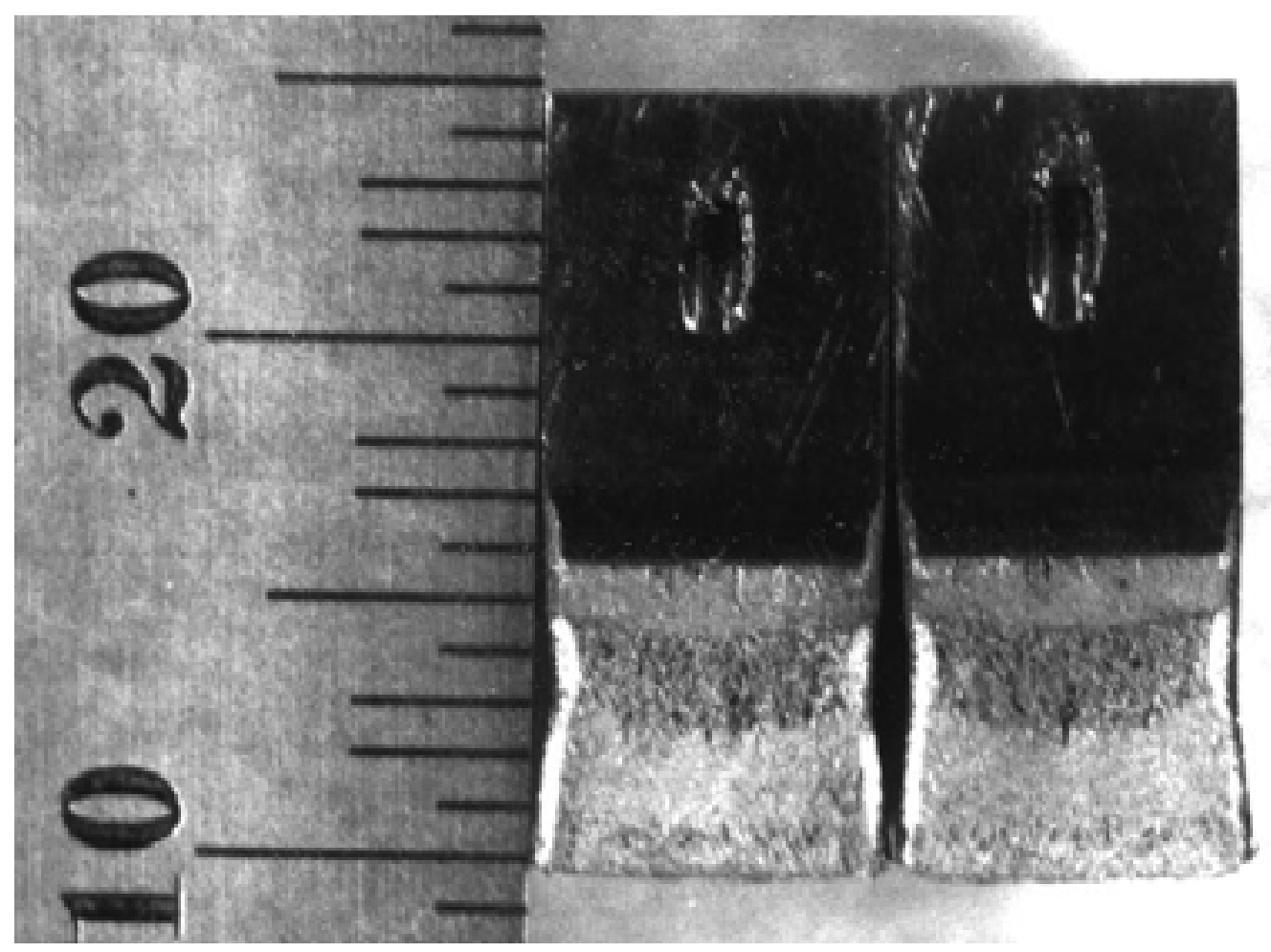

Figure A-12.2. Fracture surface of specimen $\mathrm{L} 2-\mathrm{C}$ tested at $288^{\circ} \mathrm{C}$ 
Table A-13. Test data for specimen L2-E of nonirradiated Type 304 SS tested at $288^{\circ} \mathrm{C}$

$\begin{array}{ll}\text { Test Number } & : \text { JR-30 } \\ \text { Material Type } & : \text { Type 304 SS } \\ \text { Aging Temp. } & :- \\ \text { Irradiation Temp. } & :- \\ \text { Thickness } & : 6.49 \mathrm{~mm} \\ \text { Width } & : 12.03 \mathrm{~mm} \\ \text { Modulus E } & : 175 \mathrm{GPa} \\ \text { Initial Crack } & : 7.38 \mathrm{~mm} \\ \text { Final Crack } & : 9.17 \mathrm{~mm} \\ \text { Final Crack } & : 8.08 \mathrm{~mm}\end{array}$

$\begin{array}{ll}\text { Test Temp. } & : 288^{\circ} \mathrm{C} \\ \text { Heat Number } & : \mathrm{L} 2 \\ \text { Aging Time } & :- \\ \text { Fluence } & :- \\ \text { Net Thickness } & : 5.87 \mathrm{~mm} \\ \text { Flow Stress } & : 270.5 \mathrm{MPa} \\ & \\ \text { Init. a/W } & : 0.61 \text { (Measured) } \\ \text { Final a/W } & : 0.76 \text { (Measured) } \\ \text { Final a/W } & : 0.75 \text { (Compliance) }\end{array}$

\begin{tabular}{|c|c|c|c|c|c|c|}
\hline \multirow[b]{2}{*}{ No. } & \multirow{2}{*}{$\begin{array}{c}\text { Load } \\
(\mathrm{kN})\end{array}$} & \multirow{2}{*}{$\begin{array}{l}\text { Deflection } \\
(\mathrm{mm})\end{array}$} & \multicolumn{2}{|c|}{ Unloading Compliance } & \multicolumn{2}{|c|}{ DC Potential Method } \\
\hline & & & $\mathrm{J}\left(\mathrm{kJ} / \mathrm{m}^{2}\right)$ & $\Delta \mathrm{a}(\mathrm{mm})$ & $\mathrm{J}\left(\mathrm{kJ} / \mathrm{m}^{2}\right)$ & $\Delta \mathrm{a}(\mathrm{mm})$ \\
\hline 0 & 0.0885 & 0.000 & & & & \\
\hline 1 & 1.1441 & 0.052 & 4.2 & 0.027 & 4.2 & 0.004 \\
\hline 2 & 1.2273 & 0.144 & 13.0 & 0.049 & 13.1 & 0.012 \\
\hline 3 & 1.3033 & 0.238 & 23.0 & -0.020 & 22.6 & 0.021 \\
\hline 4 & 1.3669 & 0.334 & 32.8 & 0.057 & 32.9 & 0.030 \\
\hline 5 & 1.4225 & 0.430 & 44.4 & -0.014 & 43.7 & 0.041 \\
\hline 6 & 1.4741 & 0.527 & 55.9 & -0.022 & 55.0 & 0.052 \\
\hline 7 & 1.5226 & 0.624 & 65.5 & 0.102 & 66.7 & 0.061 \\
\hline 8 & 1.5627 & 0.722 & 78.0 & 0.088 & 78.8 & 0.072 \\
\hline 9 & 1.6022 & 0.820 & 88.5 & 0.185 & 91.2 & 0.082 \\
\hline 10 & 1.6347 & 0.918 & 99.6 & 0.261 & 102.2 & 0.173 \\
\hline 11 & 1.6534 & 1.019 & 116.8 & 0.150 & 114.1 & 0.218 \\
\hline 12 & 1.6743 & 1.118 & 123.1 & 0.371 & 126.3 & 0.266 \\
\hline 13 & 1.6908 & 1.219 & 142.0 & 0.244 & 138.8 & 0.312 \\
\hline 14 & 1.7019 & 1.320 & 147.3 & 0.468 & 151.2 & 0.362 \\
\hline 15 & 1.7095 & 1.421 & 159.3 & 0.523 & 163.8 & 0.411 \\
\hline 16 & 1.7166 & 1.522 & 175.1 & 0.512 & 176.2 & 0.463 \\
\hline 17 & 1.7192 & 1.630 & 185.8 & 0.619 & 189.7 & 0.512 \\
\hline 18 & 1.7143 & 1.732 & 203.4 & 0.584 & 201.9 & 0.568 \\
\hline 19 & 1.6899 & 1.835 & 211.2 & 0.715 & 213.6 & 0.633 \\
\hline 20 & 1.6690 & 1.938 & 228.6 & 0.688 & 224.1 & 0.709 \\
\hline 21 & 1.6561 & 2.041 & 255.8 & 0.535 & 235.1 & 0.771 \\
\hline 22 & 1.6458 & 2.143 & 242.8 & 0.899 & 246.1 & 0.835 \\
\hline 23 & 1.6276 & 2.246 & 263.8 & 0.819 & 256.8 & 0.899 \\
\hline 24 & 1.6009 & 2.350 & 277.7 & 0.848 & 266.7 & 0.971 \\
\hline 25 & 1.5867 & 2.453 & 284.1 & 0.949 & 276.6 & 1.037 \\
\hline 26 & 1.5529 & 2.557 & 307.0 & 0.874 & 285.8 & 1.113 \\
\hline 27 & 1.5280 & 2.661 & 305.2 & 1.049 & 294.6 & 1.185 \\
\hline 28 & 1.4928 & 2.765 & 318.5 & 1.064 & 302.9 & 1.261 \\
\hline 29 & 1.4599 & 2.870 & 314.4 & 1.244 & 310.9 & 1.335 \\
\hline 30 & 1.4265 & 2.975 & 322.2 & 1.307 & 316.6 & 1.412 \\
\hline 31 & 1.3963 & 3.080 & 335.2 & 1.329 & 325.3 & 1.489 \\
\hline 32 & 1.3705 & 3.184 & 341.3 & 1.406 & 332.3 & 1.559 \\
\hline 33 & 1.3300 & 3.289 & 334.7 & 1.579 & 339.7 & 1.627 \\
\hline 34 & 1.2771 & 3.396 & 340.4 & 1.649 & 345.0 & 1.710 \\
\hline 35 & 1.2371 & 3.501 & 348.0 & 1.706 & 349.1 & 1.792 \\
\hline
\end{tabular}

Power-Law Fit

Unloading Compliance

Coeff. C : $275 \mathrm{~kJ} / \mathrm{m}^{2}$

DC Potential Method

Coeff. C : $268 \mathrm{~kJ} / \mathrm{m}^{2}$
$\mathrm{J}=\mathrm{C}(\Delta \mathrm{a})^{\mathrm{n}}$

$\mathrm{J}_{\mathrm{Ic}} \quad: 154 \mathrm{~kJ} / \mathrm{m}^{2} \quad$ (25 Data)

Exponent n : 0.54

J $\quad: 159 \mathrm{~kJ} / \mathrm{m}^{2}$

Fit Coeff. R : 0.866

(19 Data)

Fit Coeff. R : 0.997 


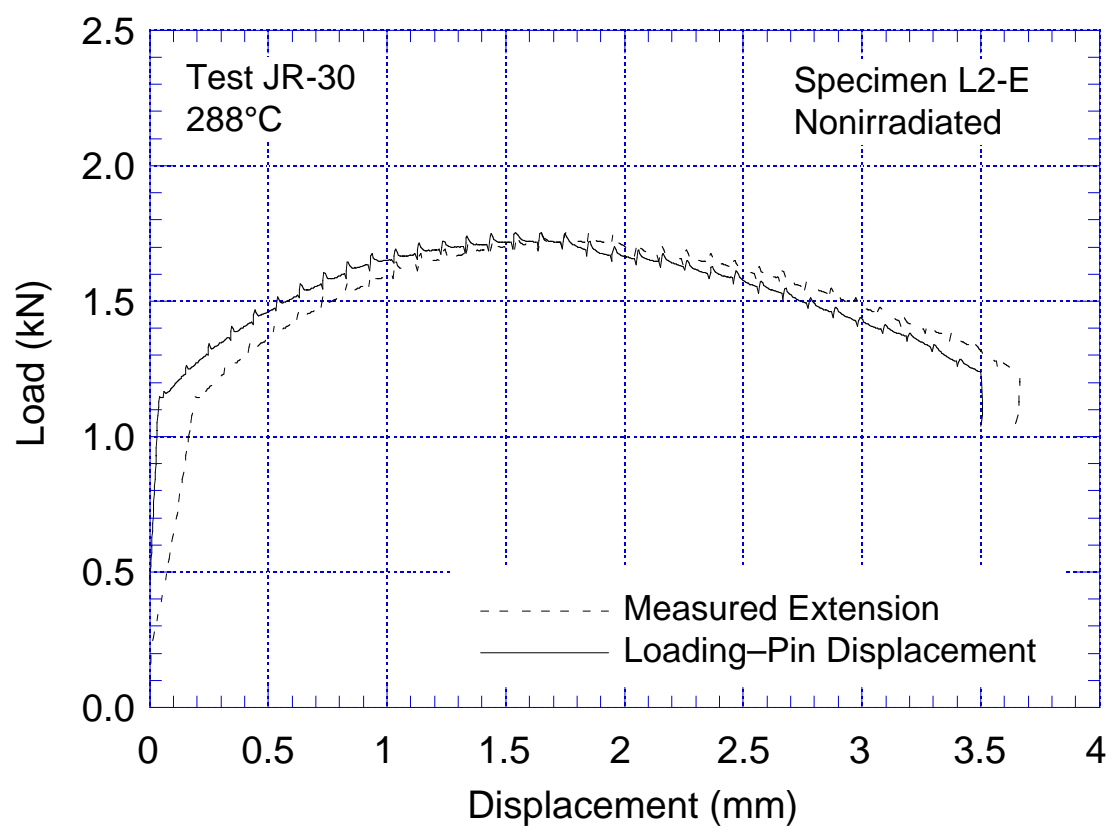

Figure A-13.1. Load-vs.-loadline displacement curve for specimen L2-E of nonirradiated Type 304 SS tested at $288^{\circ} \mathrm{C}$

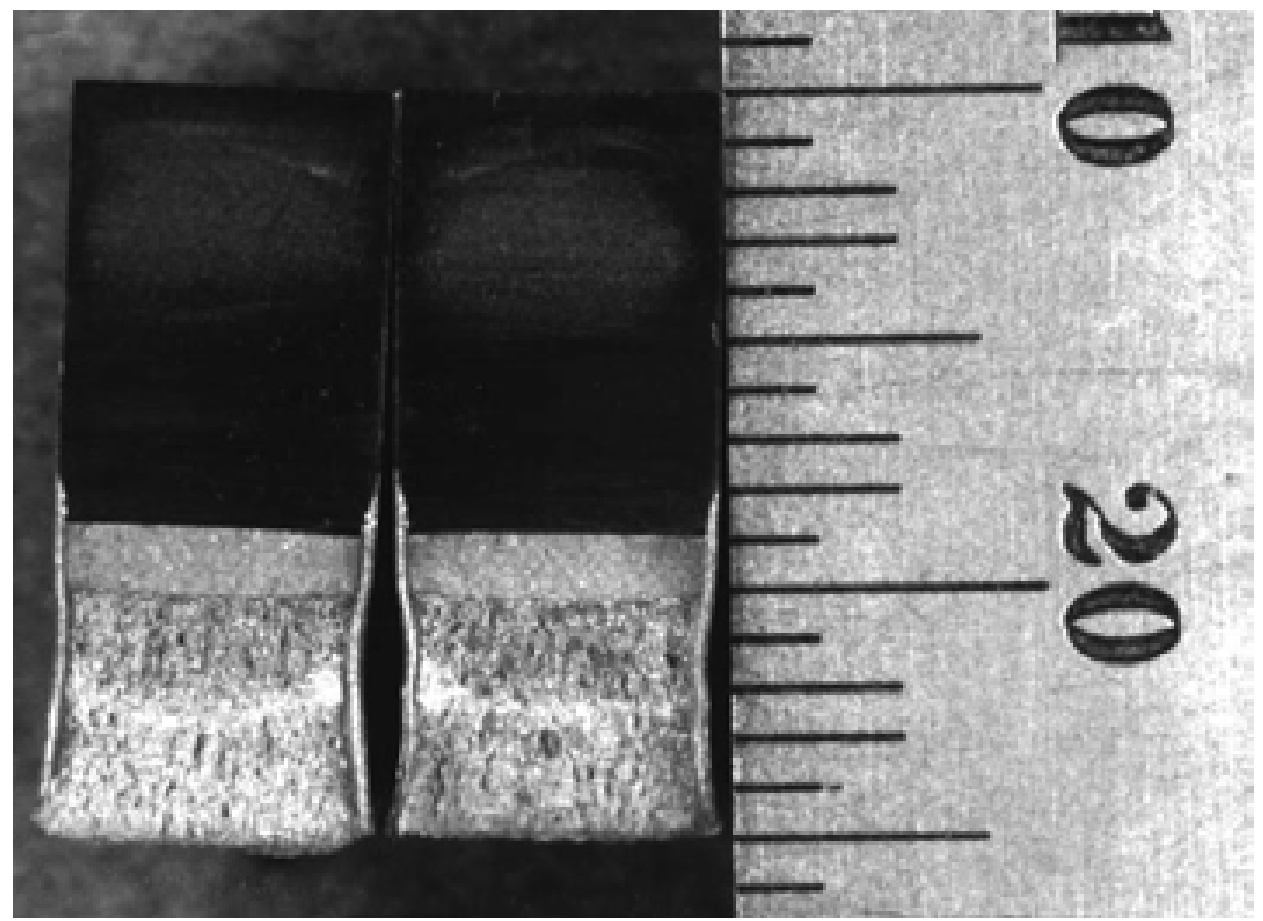

Figure A-13.2. Fracture surface of specimen $\mathrm{L} 2-\mathrm{E}$ tested at $288^{\circ} \mathrm{C}$ 
Table A-14. Test data for specimen C19-A of irradiated Type 304 SS tested at $288^{\circ} \mathrm{C}$

$\begin{array}{ll}\text { Test Number } & : \text { JRI-21 } \\ \text { Material Type } & : \text { Type } 304 \mathrm{SS} \\ \text { Aging Temp. } & :- \\ \text { Irradiation Temp. } & : 288^{\circ} \mathrm{C} \\ \text { Thickness } & : 6.50 \mathrm{~mm} \\ \text { Width } & : 12.00 \mathrm{~mm} \\ \text { Modulus E } & : 175 \mathrm{GPa} \\ \text { Initial Crack } & : 7.45 \mathrm{~mm} \\ \text { Final Crack } & : 8.84 \mathrm{~mm} \\ \text { Final Crack } & : 8.32 \mathrm{~mm}\end{array}$

$\begin{array}{ll}\text { Test Temp. } & : 288^{\circ} \mathrm{C} \\ \text { Heat Number } & : \mathrm{C} 19 \\ \text { Aging Time } & :- \\ \text { Fluence } & : 0.3 \times 10^{21} \mathrm{n} / \mathrm{cm}^{2} \\ \text { Net Thickness } & : 5.85 \mathrm{~mm} \\ \text { Flow Stress } & : 618.0 \mathrm{MPa} \\ \text { Effective Flow Stress } & : 478.8 \mathrm{MPa} \\ \text { Init. a/W } & : 0.62 \text { (Measured) } \\ \text { Final a/W } & : 0.74 \text { (Measured) } \\ \text { Final a/W } & : 0.69 \text { (Compliance) }\end{array}$

\begin{tabular}{|c|c|c|c|c|c|c|}
\hline \multirow[b]{2}{*}{ No. } & \multirow{2}{*}{$\begin{array}{c}\text { Load } \\
(\mathrm{kN})\end{array}$} & \multirow{2}{*}{$\begin{array}{l}\text { Deflection } \\
(\mathrm{mm})\end{array}$} & \multicolumn{2}{|c|}{ Unloading Compliance } & \multicolumn{2}{|c|}{ DC Potential Method } \\
\hline & & & $\mathrm{J}\left(\mathrm{kJ} / \mathrm{m}^{2}\right)$ & $\Delta \mathrm{a}(\mathrm{mm})$ & $\mathrm{J}\left(\mathrm{kJ} / \mathrm{m}^{2}\right)$ & $\Delta \mathrm{a}(\mathrm{mm})$ \\
\hline 0 & 0.088 & 0.000 & & & & \\
\hline 1 & 2.618 & 1.094 & 204.8 & 0.000 & 204.3 & 0.107 \\
\hline 2 & 2.637 & 1.194 & 226.8 & 0.000 & 226.0 & 0.118 \\
\hline 3 & 2.658 & 1.295 & 249.3 & 0.000 & 248.1 & 0.130 \\
\hline 4 & 2.673 & 1.395 & 271.4 & 0.000 & 270.1 & 0.140 \\
\hline 5 & 2.687 & 1.497 & 294.4 & 0.000 & 292.7 & 0.153 \\
\hline 6 & 2.702 & 1.597 & 316.8 & 0.000 & 314.9 & 0.164 \\
\hline 7 & 2.701 & 1.699 & 339.5 & 0.000 & 337.1 & 0.179 \\
\hline 8 & 2.706 & 1.802 & 356.2 & 0.068 & 360.2 & 0.188 \\
\hline 9 & 2.705 & 1.902 & 372.4 & 0.132 & 382.8 & 0.196 \\
\hline 10 & 2.708 & 2.004 & 405.3 & 0.044 & 405.0 & 0.213 \\
\hline 11 & 2.705 & 2.104 & 427.5 & 0.050 & 430.1 & 0.227 \\
\hline 12 & 2.698 & 2.207 & 438.3 & 0.152 & 453.5 & 0.232 \\
\hline 13 & 2.680 & 2.310 & 461.9 & 0.149 & 475.0 & 0.251 \\
\hline 14 & 2.666 & 2.414 & 486.0 & 0.147 & 487.4 & 0.336 \\
\hline 15 & 2.645 & 2.516 & 507.6 & 0.158 & 499.7 & 0.415 \\
\hline 16 & 2.613 & 2.619 & 522.2 & 0.215 & 510.7 & 0.502 \\
\hline 17 & 2.589 & 2.723 & 545.4 & 0.215 & 521.8 & 0.587 \\
\hline 18 & 2.562 & 2.827 & 566.4 & 0.227 & 531.2 & 0.681 \\
\hline 19 & 2.526 & 2.931 & 585.2 & 0.252 & 544.1 & 0.748 \\
\hline 20 & 2.460 & 3.037 & 570.7 & 0.467 & 555.4 & 0.829 \\
\hline 21 & 2.425 & 3.143 & 580.0 & 0.541 & 565.2 & 0.913 \\
\hline 22 & 2.395 & 3.246 & 587.8 & 0.623 & 575.7 & 0.987 \\
\hline 23 & 2.354 & 3.351 & 608.1 & 0.639 & 586.4 & 1.062 \\
\hline 24 & 2.332 & 3.454 & 637.1 & 0.607 & 595.9 & 1.138 \\
\hline 25 & 2.267 & 3.561 & 633.3 & 0.741 & 604.7 & 1.220 \\
\hline 26 & 2.218 & 3.666 & 652.0 & 0.757 & 611.3 & 1.307 \\
\hline 27 & 2.166 & 3.771 & 649.6 & 0.874 & 617.3 & 1.393 \\
\hline
\end{tabular}

Power-Law Fit

Unloading Compliance

Coeff. C $\quad: 661 \mathrm{~kJ} / \mathrm{m}^{2}$

DC Potential Method

Coeff. C : $579 \mathrm{~kJ} / \mathrm{m}^{2}$
$\mathrm{J}=\mathrm{C}(\Delta \mathrm{a})^{\mathrm{n}}$

$\mathrm{J}_{\mathrm{Ic}} \quad: 599 \mathrm{~kJ} / \mathrm{m}^{2} \quad$ (15 Data)

Exponent $\mathrm{n}: 0 . .15$

J $\quad: 507 \mathrm{~kJ} / \mathrm{m}^{2} \quad$ (17 Data)

Exponent $n: 0.17$
Fit Coeff. R : 0.834

Fit Coeff. $\mathrm{R}$ : 0.975 


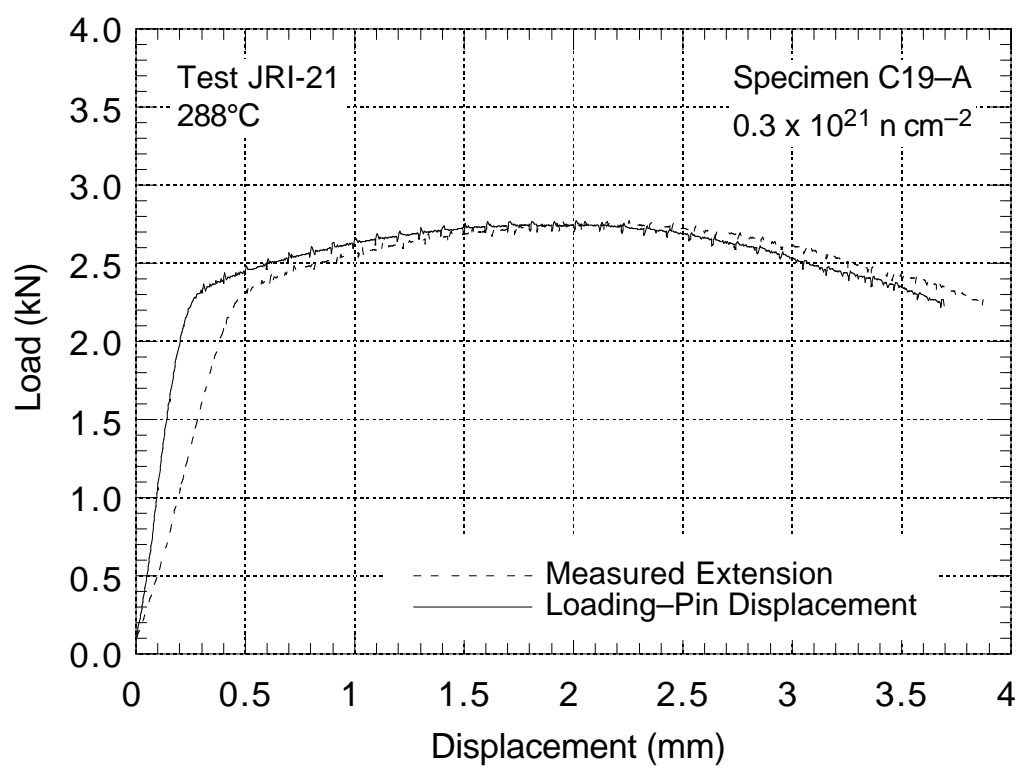

Figure A-14.1 Load-vs.-loadline displacement curve for specimen C19-A of irradiated Type 304 SS tested at $288^{\circ} \mathrm{C}$

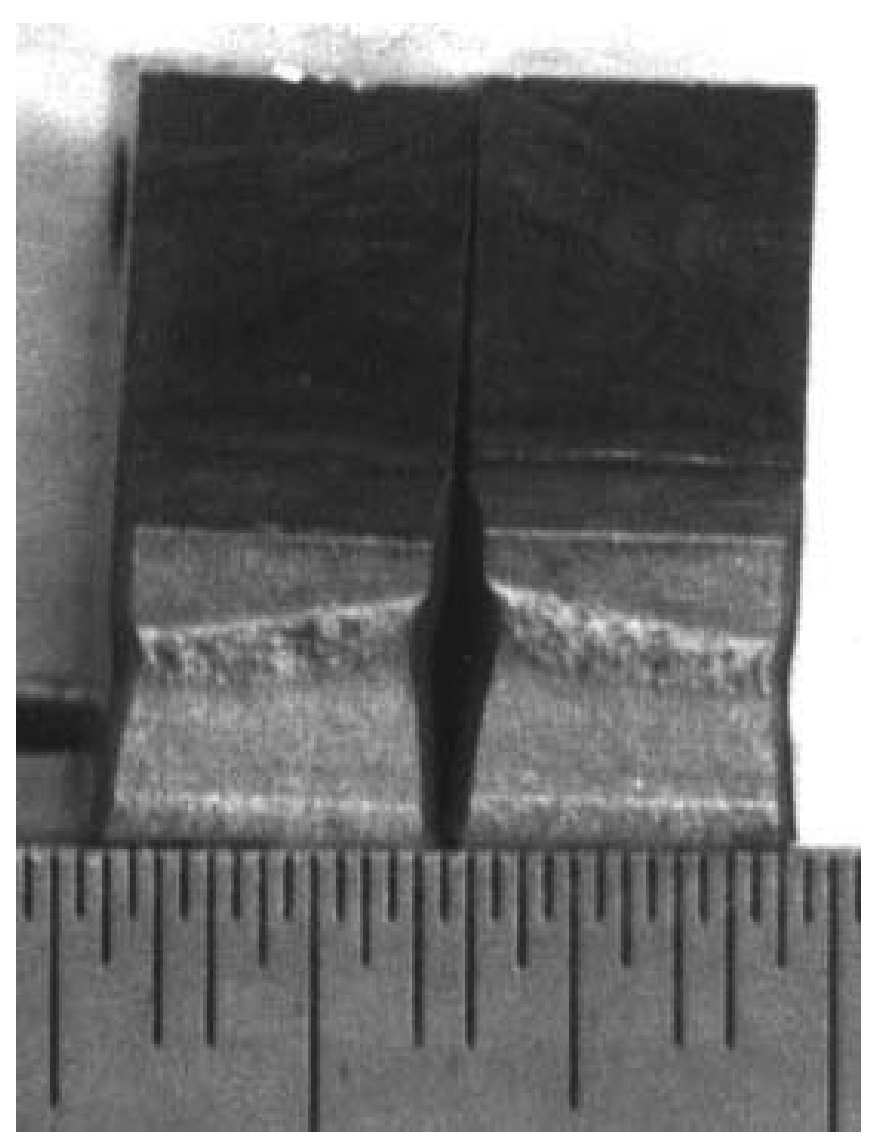

Figure A-14.2 Fracture surface of specimen $\mathrm{C} 19-\mathrm{A}$ tested at $288^{\circ} \mathrm{C}$ 
Table A-15. Test data for specimen C19-B of irradiated Type 304 SS tested at $288^{\circ} \mathrm{C}$

$\begin{array}{ll}\text { Test Number } & : \text { JRI-23 } \\ \text { Material Type } & : \text { Type } 304 \mathrm{SS} \\ \text { Aging Temp. } & :- \\ \text { Irradiation Temp. } & : 288^{\circ} \mathrm{C} \\ \text { Thickness } & : 6.50 \mathrm{~mm} \\ \text { Width } & : 12.00 \mathrm{~mm} \\ \text { Modulus E } & : 175 \mathrm{GPa} \\ \text { Initial Crack } & : 7.36 \mathrm{~mm} \\ \text { Final Crack } & : 9.40 \mathrm{~mm} \\ \text { Final Crack } & : 9.01 \mathrm{~mm}\end{array}$

$\begin{array}{ll}\text { Test Temp. } & : 288^{\circ} \mathrm{C} \\ \text { Heat Number } & : \mathrm{C} 19 \\ \text { Aging Time } & :- \\ \text { Fluence } & : 0.9 \times 10^{21} \mathrm{n} / \mathrm{cm}^{2} \\ \text { Net Thickness } & : 5.85 \mathrm{~mm} \\ \text { Flow Stress } & : 759.5 \mathrm{MPa} \\ \text { Effective Flow Stress } & : 549.5 \mathrm{MPa} \\ \text { Init. a/W } & : 0.61 \text { (Measured) } \\ \text { Final a/W } & : 0.78 \text { (Measured) } \\ \text { Final a/W } & : 0.75 \text { (Compliance) }\end{array}$

\begin{tabular}{|c|c|c|c|c|c|c|}
\hline \multirow[b]{2}{*}{ No. } & \multirow{2}{*}{$\begin{array}{c}\text { Load } \\
(\mathrm{kN})\end{array}$} & \multirow{2}{*}{$\begin{array}{c}\text { Deflection } \\
(\mathrm{mm})\end{array}$} & \multicolumn{2}{|c|}{ Unloading Compliance } & \multicolumn{2}{|c|}{ DC Potential Method } \\
\hline & & & $\mathrm{J}\left(\mathrm{kJ} / \mathrm{m}^{2}\right)$ & $\Delta \mathrm{a}(\mathrm{mm})$ & $\mathrm{J}\left(\mathrm{kJ} / \mathrm{m}^{2}\right)$ & $\Delta \mathrm{a}(\mathrm{mm})$ \\
\hline 0 & 0.088 & 0.000 & & & & \\
\hline 1 & 1.971 & 0.125 & 9.7 & -0.014 & 9.8 & 0.004 \\
\hline 2 & 2.630 & 0.176 & 19.2 & -0.376 & 19.1 & 0.007 \\
\hline 3 & 3.185 & 0.236 & 26.7 & -0.041 & 33.1 & 0.010 \\
\hline 4 & 3.544 & 0.311 & 52.4 & 0.055 & 53.7 & 0.020 \\
\hline 5 & 3.643 & 0.404 & 78.0 & 0.081 & 80.5 & 0.030 \\
\hline 6 & 3.636 & 0.519 & 110.5 & 0.159 & 114.3 & 0.043 \\
\hline 7 & 3.589 & 0.624 & 142.0 & 0.119 & 144.7 & 0.055 \\
\hline 8 & 3.527 & 0.729 & 172.2 & 0.155 & 174.6 & 0.067 \\
\hline 9 & 3.469 & 0.836 & 205.8 & 0.095 & 204.6 & 0.080 \\
\hline 10 & 3.426 & 0.941 & 233.9 & 0.143 & 233.5 & 0.091 \\
\hline 11 & 3.341 & 1.047 & 259.4 & 0.199 & 262.3 & 0.101 \\
\hline 12 & 3.266 & 1.153 & 281.3 & 0.294 & 285.4 & 0.210 \\
\hline 13 & 3.195 & 1.259 & 309.3 & 0.296 & 304.8 & 0.309 \\
\hline 14 & 3.124 & 1.366 & 335.0 & 0.334 & 324.7 & 0.397 \\
\hline 15 & 3.058 & 1.472 & 357.7 & 0.390 & 344.5 & 0.479 \\
\hline 16 & 2.959 & 1.581 & 384.2 & 0.405 & 363.8 & 0.566 \\
\hline 17 & 2.880 & 1.689 & 404.9 & 0.467 & 381.4 & 0.657 \\
\hline 18 & 2.793 & 1.796 & 416.2 & 0.590 & 397.9 & 0.746 \\
\hline 19 & 2.709 & 1.903 & 440.3 & 0.599 & 413.7 & 0.832 \\
\hline 20 & 2.647 & 2.009 & 461.1 & 0.640 & 428.7 & 0.918 \\
\hline 21 & 2.539 & 2.169 & 486.0 & 0.730 & 452.1 & 1.040 \\
\hline 22 & 2.431 & 2.329 & 508.4 & 0.819 & 471.2 & 1.169 \\
\hline 23 & 2.284 & 2.491 & 524.1 & 0.941 & 487.7 & 1.301 \\
\hline 24 & 2.184 & 2.649 & 538.6 & 1.048 & 503.1 & 1.416 \\
\hline 25 & 2.060 & 2.811 & 550.1 & 1.167 & 515.4 & 1.550 \\
\hline 26 & 1.951 & 2.970 & 552.7 & 1.318 & 522.6 & 1.694 \\
\hline 27 & 1.834 & 3.131 & 559.7 & 1.436 & 529.4 & 1.823 \\
\hline 28 & 1.743 & 3.290 & 569.4 & 1.534 & 537.1 & 1.939 \\
\hline 29 & 1.657 & 3.449 & 574.7 & 1.647 & 546.4 & 2.041 \\
\hline
\end{tabular}

Power-Law Fit

Unloading Compliance

Coeff. C $\quad: 513 \mathrm{~kJ} / \mathrm{m}^{2}$

DC Potential Method

Coeff. C $\quad: 442 \mathrm{~kJ} / \mathrm{m}^{2}$
$\mathrm{J}=\mathrm{C}(\Delta \mathrm{a})^{\mathrm{n}}$

$\mathrm{J}_{\mathrm{Ic}} \quad: 368 \mathrm{~kJ} / \mathrm{m}^{2} \quad$ (16 Data)

Exponent $\mathrm{n}: 0.33$

$\mathrm{J}_{\mathrm{Ic}} \quad: 313 \mathrm{~kJ} / \mathrm{m}^{2}$

Fit Coeff. R : 0.948

(17 Data)

Fit Coeff. R : 0.996 


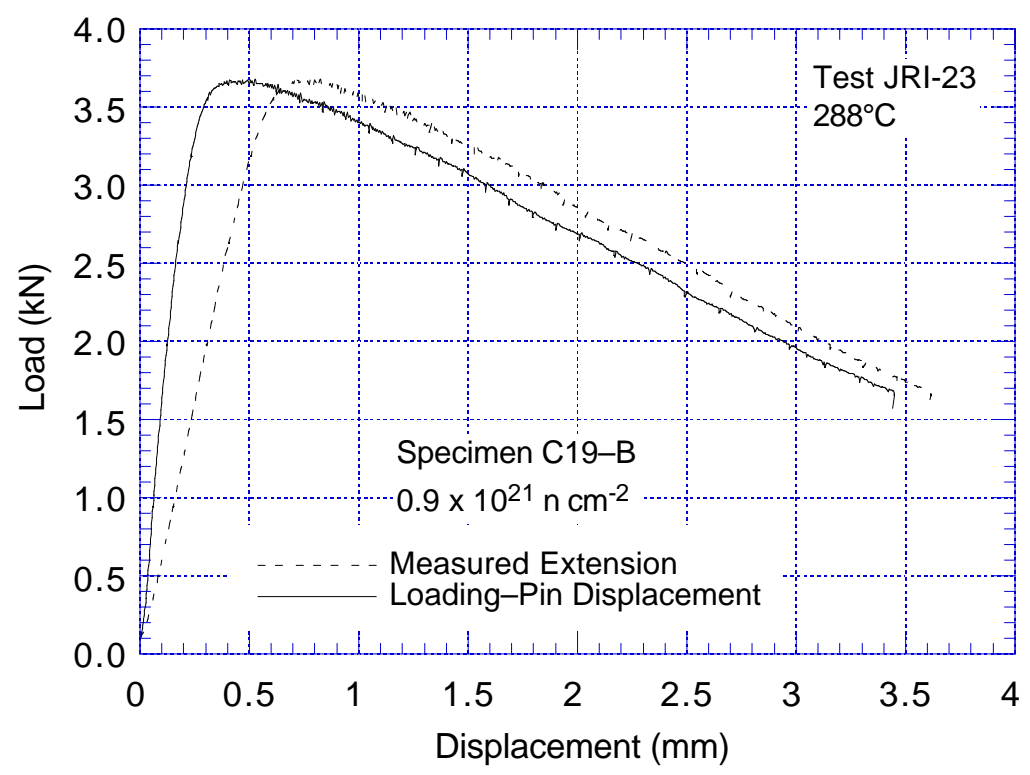

Figure A-15.1 Load-vs.-loadline displacement curve for specimen C19-B of irradiated Type $304 \mathrm{SS}$ tested at $288^{\circ} \mathrm{C}$

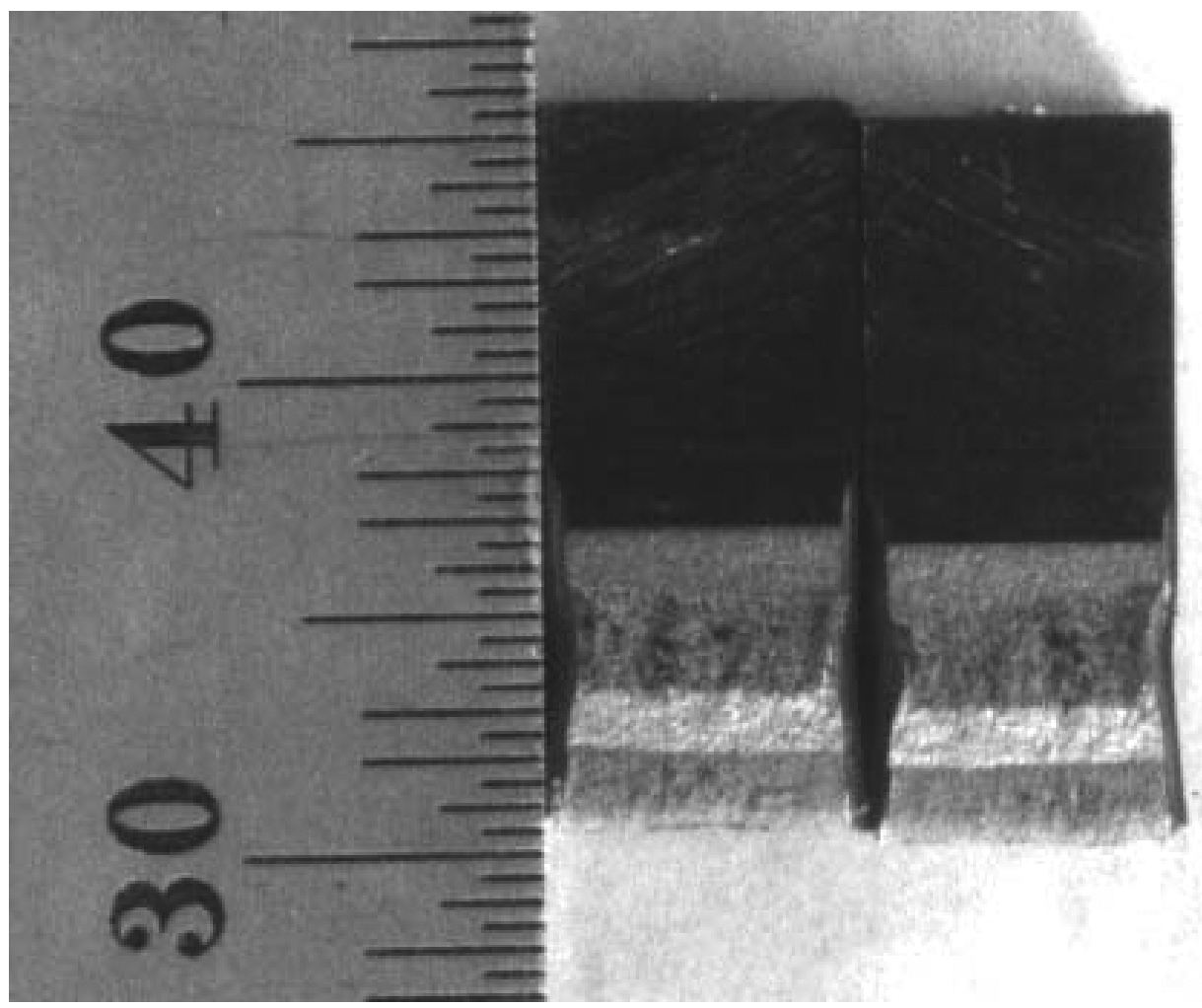

Figure A-15.2 Fracture surface of specimen C19-B tested at $288^{\circ} \mathrm{C}$ 
Table A-16. Test data for specimen C19-C of irradiated Type 304 SS tested at $288^{\circ} \mathrm{C}$

$\begin{array}{llll}\text { Test Number } & : \text { JRI-33 } & \text { Test Temp. } & : 288^{\circ} \mathrm{C} \\ \text { Material Type } & : \text { Type 304 SS } & \text { Heat Number } & : \mathrm{C} 19 \\ \text { Aging Temp. } & :- & \text { Aging Time } & :- \\ \text { Irradiation Temp. } & : 288^{\circ} \mathrm{C} & \text { Fluence } & : 2.0 \times 10^{21} \mathrm{n} / \mathrm{cm}^{2} \\ \text { Thickness } & : 6.50 \mathrm{~mm} & \text { Net Thickness } & : 5.85 \mathrm{~mm} \\ \text { Width } & : 12.00 \mathrm{~mm} & \text { Flow Stress } & : 794.0 \mathrm{MPa} \\ \text { Modulus E } & : 175 \mathrm{GPa} & \text { Effective Flow Stress } & : 566.8 \mathrm{MPa} \\ \text { Initial Crack } & : 7.38 \mathrm{~mm} & \text { Init. a/W } & : 0.61 \text { (Measured) } \\ \text { Final Crack } & : 9.20 \mathrm{~mm} & \text { Final a/W } & : 0.77 \text { (Measured) } \\ \text { Final Crack } & : 9.13 \mathrm{~mm} & \text { Final a/W } & : 0.76 \text { (Compliance) }\end{array}$

\begin{tabular}{|c|c|c|c|c|c|c|}
\hline \multirow[b]{2}{*}{ No. } & \multirow{2}{*}{$\begin{array}{c}\text { Load } \\
(\mathrm{kN})\end{array}$} & \multirow{2}{*}{$\begin{array}{l}\text { Deflection } \\
(\mathrm{mm})\end{array}$} & \multicolumn{2}{|c|}{ Unloading Compliance } & \multicolumn{2}{|c|}{ DC Potential Method } \\
\hline & & & $\mathrm{J}\left(\mathrm{kJ} / \mathrm{m}^{2}\right)$ & $\Delta \mathrm{a}(\mathrm{mm})$ & $\mathrm{J}\left(\mathrm{kJ} / \mathrm{m}^{2}\right)$ & $\Delta \mathrm{a}(\mathrm{mm})$ \\
\hline 0 & 0.089 & 0.000 & & & & \\
\hline 1 & 0.621 & 0.040 & 1.1 & -0.254 & & \\
\hline 2 & 0.930 & 0.061 & 2.1 & -0.011 & & \\
\hline 3 & 1.251 & 0.082 & 4.3 & 0.047 & & \\
\hline 4 & 1.586 & 0.106 & 7.3 & -0.034 & & \\
\hline 5 & 1.911 & 0.129 & 10.3 & -0.078 & & \\
\hline 6 & 2.234 & 0.156 & 14.3 & -0.103 & & \\
\hline 7 & 2.543 & 0.182 & 19.2 & -0.381 & & \\
\hline 8 & 2.839 & 0.210 & 23.2 & -0.388 & & \\
\hline 9 & 3.108 & 0.240 & 29.1 & -0.253 & & \\
\hline 10 & 3.352 & 0.273 & 35.0 & -0.176 & & \\
\hline 11 & 3.540 & 0.310 & 42.9 & -0.090 & & \\
\hline 12 & 3.668 & 0.350 & 52.3 & -0.044 & & \\
\hline 13 & 3.718 & 0.397 & 64.4 & 0.038 & & \\
\hline 14 & 3.691 & 0.449 & 78.8 & 0.003 & & \\
\hline 15 & 3.627 & 0.504 & 96.1 & 0.006 & & \\
\hline 16 & 3.546 & 0.558 & 110.7 & 0.072 & & \\
\hline 17 & 3.412 & 0.668 & 140.4 & 0.102 & & \\
\hline 18 & 3.232 & 0.781 & 168.7 & 0.168 & & \\
\hline 19 & 3.070 & 0.893 & 190.6 & 0.311 & & \\
\hline 20 & 2.926 & 1.004 & 212.8 & 0.387 & & \\
\hline 21 & 2.746 & 1.118 & 228.3 & 0.575 & & \\
\hline 22 & 2.569 & 1.232 & 239.9 & 0.762 & & \\
\hline 23 & 2.426 & 1.343 & 248.2 & 0.956 & & \\
\hline 24 & 2.294 & 1.453 & 256.6 & 1.122 & & \\
\hline 25 & 2.166 & 1.564 & 269.5 & 1.230 & & \\
\hline 26 & 2.073 & 1.672 & 280.5 & 1.351 & & \\
\hline 27 & 1.963 & 1.780 & 297.9 & 1.445 & & \\
\hline 28 & 1.871 & 1.889 & 306.0 & 1.523 & & \\
\hline 29 & 1.795 & 1.997 & 318.9 & 1.599 & & \\
\hline 30 & 1.700 & 2.105 & 329.9 & 1.680 & & \\
\hline 31 & 1.625 & 2.212 & 340.0 & 1.757 & & \\
\hline
\end{tabular}

Power-Law Fit

Unloading Compliance

Coeff. C : $268 \mathrm{~kJ} / \mathrm{m}^{2}$

DC Potential Method
$\mathrm{J}=\mathrm{C}(\Delta \mathrm{a})^{\mathrm{n}}$

$\mathrm{J}_{\mathrm{Ic}} \quad: 188 \mathrm{~kJ} / \mathrm{m}^{2} \quad$ (15 Data)

Exponent $\mathrm{n}: 0.28 \quad$ Fit Coeff. $\mathrm{R}: 0.967$

(information could not be determined) 


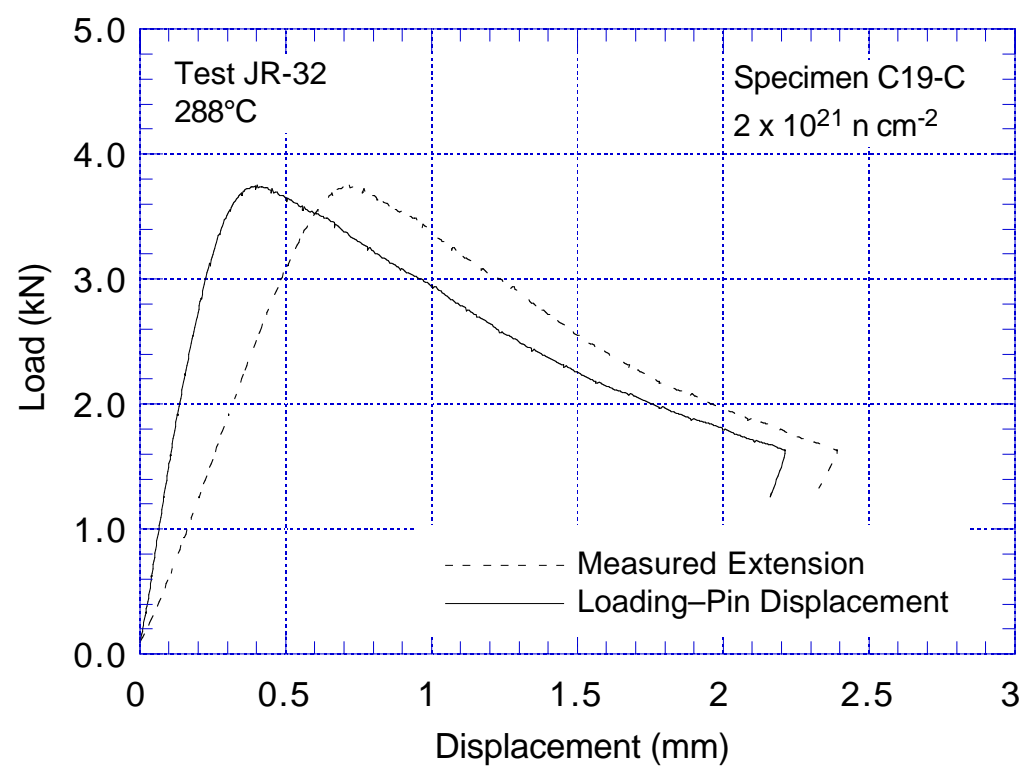

Figure A-16.1 Load-vs.-loadline displacement curve for specimen C19-C of irradiated Type 304 SS tested at $288^{\circ} \mathrm{C}$

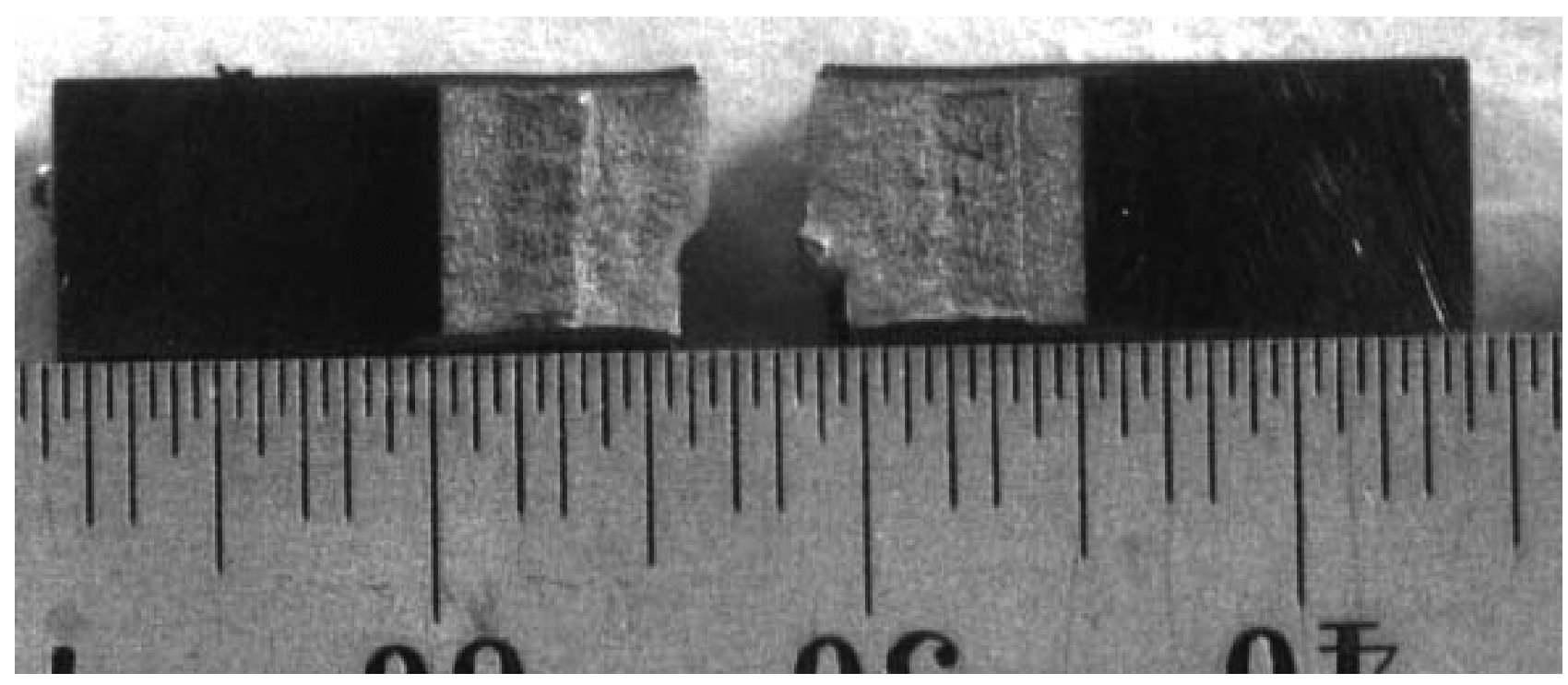

Figure A-16.2 Fracture surface of specimen $\mathrm{C} 19-\mathrm{C}$ tested at $288^{\circ} \mathrm{C}$ 
Table A-17. Test data for specimen C16-A of irradiated Type 316 SS tested at $288^{\circ} \mathrm{C}$

$\begin{array}{ll}\text { Test Number } & : \text { JR-26 } \\ \text { Material Type } & : \text { Type 316 SS } \\ \text { Aging Temp. } & :- \\ \text { Irradiation Temp. } & : 288^{\circ} \mathrm{C} \\ \text { Thickness } & : 6.50 \mathrm{~mm} \\ \text { Width } & : 12.00 \mathrm{~mm} \\ \text { Modulus E } & : 175 \mathrm{GPa} \\ \text { Initial Crack } & : 7.28 \mathrm{~mm} \\ \text { Final Crack } & : 8.73 \mathrm{~mm} \\ \text { Final Crack } & : 8.36 \mathrm{~mm}\end{array}$

$\begin{array}{ll}\text { Test Temp. } & : 288^{\circ} \mathrm{C} \\ \text { Heat Number } & : \mathrm{C} 16 \\ \text { Aging Time } & :- \\ \text { Fluence } & : 0.9 \times 10^{21} \mathrm{n} / \mathrm{cm}^{2} \\ \text { Net Thickness } & : 5.85 \mathrm{~mm} \\ \text { Flow Stress } & : 590.0 \mathrm{MPa} \\ \text { Effective Flow Stress } & : 463.0 \mathrm{MPa} \\ \text { Init. a/W } & : 0.61 \text { (Measured) } \\ \text { Final a/W } & : 0.73 \text { (Measured) } \\ \text { Final a/W } & : 0.70 \text { (Compliance) }\end{array}$

\begin{tabular}{|c|c|c|c|c|c|c|}
\hline \multirow[b]{2}{*}{ No. } & \multirow{2}{*}{$\begin{array}{c}\text { Load } \\
(\mathrm{kN})\end{array}$} & \multirow{2}{*}{$\begin{array}{c}\text { Deflection } \\
(\mathrm{mm})\end{array}$} & \multicolumn{2}{|c|}{ Unloading Compliance } & \multicolumn{2}{|c|}{ DC Potential Method } \\
\hline & & & $\mathrm{J}\left(\mathrm{kJ} / \mathrm{m}^{2}\right)$ & $\Delta \mathrm{a}(\mathrm{mm})$ & $\mathrm{J}\left(\mathrm{kJ} / \mathrm{m}^{2}\right)$ & $\Delta \mathrm{a}(\mathrm{mm})$ \\
\hline 0 & 0.089 & 0.000 & & & & \\
\hline 1 & 2.527 & 0.212 & 33.3 & 0.054 & 26.6 & 0.015 \\
\hline 2 & 2.702 & 0.275 & 42.4 & 0.066 & 39.8 & 0.019 \\
\hline 3 & 2.755 & 0.347 & 59.3 & 0.004 & 55.6 & 0.026 \\
\hline 4 & 2.785 & 0.421 & 74.5 & 0.024 & 72.0 & 0.033 \\
\hline 5 & 2.807 & 0.496 & 89.8 & 0.097 & 88.7 & 0.039 \\
\hline 6 & 2.810 & 0.572 & 106.4 & 0.099 & 105.4 & 0.047 \\
\hline 7 & 2.812 & 0.649 & 123.1 & 0.136 & 122.8 & 0.054 \\
\hline 8 & 2.821 & 0.725 & 141.0 & 0.117 & 139.8 & 0.062 \\
\hline 9 & 2.832 & 0.801 & 159.6 & 0.097 & 156.9 & 0.070 \\
\hline 10 & 2.818 & 0.880 & 176.6 & 0.126 & 174.5 & 0.077 \\
\hline 11 & 2.823 & 0.955 & 191.1 & 0.184 & 191.4 & 0.084 \\
\hline 12 & 2.821 & 1.031 & 207.2 & 0.202 & 208.3 & 0.091 \\
\hline 13 & 2.800 & 1.136 & 230.7 & 0.217 & 230.0 & 0.139 \\
\hline 14 & 2.805 & 1.236 & 255.9 & 0.189 & 249.9 & 0.183 \\
\hline 15 & 2.784 & 1.338 & 279.1 & 0.198 & 269.6 & 0.234 \\
\hline 16 & 2.785 & 1.441 & 294.0 & 0.310 & 289.0 & 0.290 \\
\hline 17 & 2.770 & 1.544 & 313.2 & 0.356 & 307.9 & 0.346 \\
\hline 18 & 2.745 & 1.647 & 343.0 & 0.293 & 327.1 & 0.397 \\
\hline 19 & 2.720 & 1.751 & 354.0 & 0.430 & 345.8 & 0.456 \\
\hline 20 & 2.693 & 1.853 & 378.8 & 0.410 & 363.3 & 0.515 \\
\hline 21 & 2.655 & 1.957 & 402.9 & 0.413 & 380.8 & 0.576 \\
\hline 22 & 2.619 & 2.063 & 414.2 & 0.521 & 398.1 & 0.638 \\
\hline 23 & 2.573 & 2.169 & 430.2 & 0.580 & 414.7 & 0.703 \\
\hline 24 & 2.539 & 2.273 & 455.9 & 0.561 & 430.3 & 0.767 \\
\hline 25 & 2.512 & 2.378 & 479.9 & 0.561 & 445.4 & 0.834 \\
\hline 26 & 2.480 & 2.482 & 498.3 & 0.595 & 461.4 & 0.888 \\
\hline 27 & 2.444 & 2.588 & 513.3 & 0.648 & 477.9 & 0.941 \\
\hline 28 & 2.393 & 2.693 & 512.5 & 0.796 & 493.9 & 0.994 \\
\hline 29 & 2.351 & 2.797 & 532.4 & 0.807 & 506.3 & 1.051 \\
\hline 30 & 2.292 & 2.904 & 550.9 & 0.836 & 521.0 & 1.111 \\
\hline 31 & 2.230 & 3.010 & 560.4 & 0.911 & 532.4 & 1.188 \\
\hline 32 & 2.180 & 3.117 & 568.0 & 0.989 & 543.1 & 1.260 \\
\hline 33 & 2.128 & 3.223 & 584.6 & 1.016 & 554.5 & 1.325 \\
\hline 34 & 2.081 & 3.328 & 596.2 & 1.068 & 565.4 & 1.390 \\
\hline 35 & 2.040 & 3.429 & 613.3 & 1.086 & 575.4 & 1.453 \\
\hline
\end{tabular}

Power-Law Fit Unloading Compliance Coeff. C : $607 \mathrm{~kJ} / \mathrm{m}^{2}$ DC Potential Method Coeff. C $\quad: 490 \mathrm{~kJ} / \mathrm{m}^{2}$
$\mathrm{J}=\mathrm{C}(\Delta \mathrm{a})^{\mathrm{n}}$

$\mathrm{J}_{\mathrm{Ic}} \quad: 353 \mathrm{~kJ} / \mathrm{m}^{2} \quad$ (12 Data)

Exponent $\mathrm{n}: 0.52$

$\mathrm{J}_{\mathrm{Ic}} \quad: 299 \mathrm{~kJ} / \mathrm{m}^{2}$

Fit Coeff. R : 0.848

(14 Data)

Fit Coeff. R : 0.997 


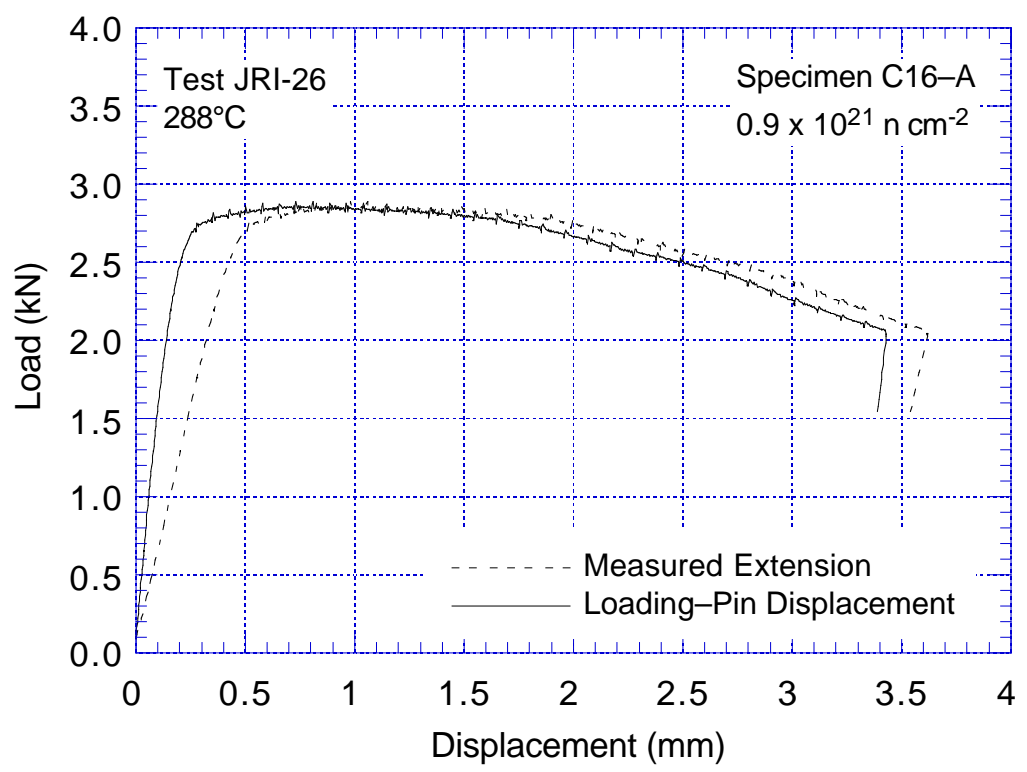

Figure A-17.1 Load-vs.-loadline displacement curve for specimen C16-A of irradiated Type 316 SS tested at $288^{\circ} \mathrm{C}$

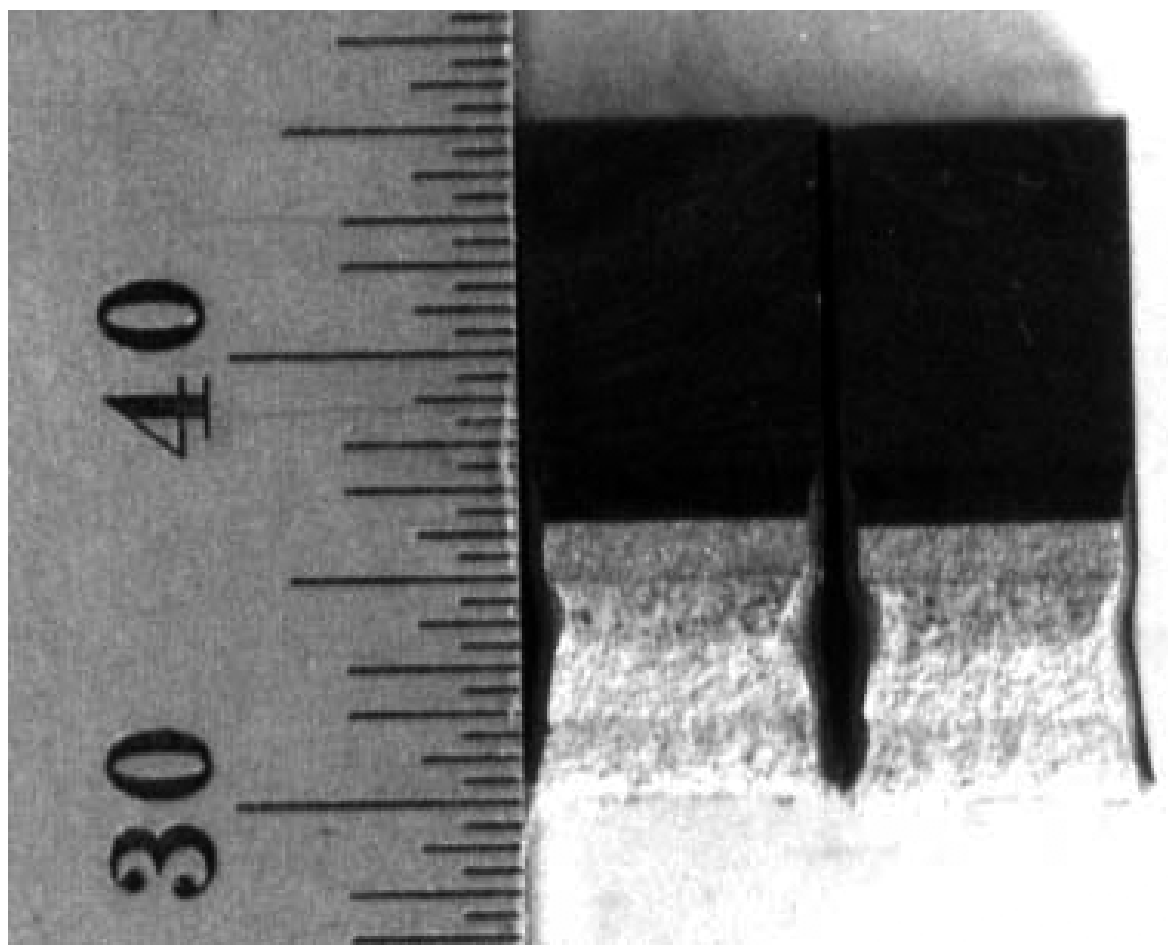

Figure A-17.2 Fracture surface of specimen $\mathrm{C} 16-\mathrm{A}$ tested at $288^{\circ} \mathrm{C}$ 
Table A-18. Test data for specimen L20-A of irradiated Type 304 SS tested at $288^{\circ} \mathrm{C}$

$\begin{array}{ll}\text { Test Number } & : \text { JR-22 } \\ \text { Material Type } & : \text { Type 304 SS } \\ \text { Aging Temp. } & :- \\ \text { Irradiation Temp. } & : 288^{\circ} \mathrm{C} \\ \text { Thickness } & : 6.50 \mathrm{~mm} \\ \text { Width } & : 2.00 \mathrm{~mm} \\ \text { Modulus E } & : 175 \mathrm{GPa} \\ \text { Initial Crack } & : 7.38 \mathrm{~mm} \\ \text { Final Crack } & : 9.17 \mathrm{~mm} \\ \text { Final Crack } & : 8.08 \mathrm{~mm}\end{array}$

$\begin{array}{ll}\text { Test Temp. } & : 288^{\circ} \mathrm{C} \\ \text { Heat Number } & : \text { L20 } \\ \text { Aging Time } & :- \\ \text { Fluence } & : 0.3 \times 10^{21} \mathrm{n} / \mathrm{cm}^{2} \\ \text { Net Thickness } & : 5.85 \mathrm{~mm} \\ \text { Flow Stress } & : 270.5 \mathrm{MPa} \\ & \\ \text { Init. a/W } & : 0.61 \text { (Measured) } \\ \text { Final a/W } & : 0.76 \text { (Measured) } \\ \text { Final a/W } & : 0.75 \text { (Compliance) }\end{array}$

\begin{tabular}{|c|c|c|c|c|c|c|}
\hline \multirow[b]{2}{*}{ No. } & \multirow{2}{*}{$\begin{array}{c}\text { Load } \\
(\mathrm{kN})\end{array}$} & \multirow{2}{*}{$\begin{array}{l}\text { Deflection } \\
(\mathrm{mm})\end{array}$} & \multicolumn{2}{|c|}{ Unloading Compliance } & \multicolumn{2}{|c|}{ DC Potential Method } \\
\hline & & & $\mathrm{J}\left(\mathrm{kJ} / \mathrm{m}^{2}\right)$ & $\Delta \mathrm{a}(\mathrm{mm})$ & $\mathrm{J}\left(\mathrm{kJ} / \mathrm{m}^{2}\right)$ & $\Delta \mathrm{a}(\mathrm{mm})$ \\
\hline 0 & 0.089 & 0.000 & & & & \\
\hline 1 & 1.300 & 0.080 & 6.5 & 0.237 & 6.5 & 0.006 \\
\hline 2 & 1.453 & 0.169 & 18.9 & 0.152 & 17.1 & 0.016 \\
\hline 3 & 1.529 & 0.265 & 30.2 & 0.155 & 29.3 & 0.028 \\
\hline 4 & 1.596 & 0.361 & 43.7 & 0.126 & 41.9 & 0.040 \\
\hline 5 & 1.648 & 0.459 & 58.7 & 0.041 & 55.2 & 0.054 \\
\hline 6 & 1.685 & 0.556 & 72.5 & 0.015 & 68.9 & 0.067 \\
\hline 7 & 1.717 & 0.656 & 87.4 & 0.027 & 83.2 & 0.080 \\
\hline 8 & 1.741 & 0.756 & 101.7 & 0.040 & 97.7 & 0.093 \\
\hline 9 & 1.754 & 0.857 & 117.1 & 0.027 & 112.4 & 0.107 \\
\hline 10 & 1.769 & 0.958 & 130.1 & 0.082 & 127.1 & 0.119 \\
\hline 11 & 1.774 & 1.059 & 144.7 & 0.101 & 142.1 & 0.132 \\
\hline 12 & 1.780 & 1.160 & 159.9 & 0.104 & 157.0 & 0.146 \\
\hline 13 & 1.775 & 1.275 & 176.7 & 0.120 & 171.1 & 0.234 \\
\hline 14 & 1.759 & 1.379 & 191.6 & 0.136 & 181.6 & 0.339 \\
\hline 15 & 1.734 & 1.482 & 203.5 & 0.200 & 192.3 & 0.432 \\
\hline 16 & 1.708 & 1.586 & 214.2 & 0.277 & 201.9 & 0.542 \\
\hline 17 & 1.692 & 1.688 & 227.3 & 0.310 & 211.0 & 0.651 \\
\hline 18 & 1.666 & 1.793 & 238.6 & 0.372 & 220.9 & 0.747 \\
\hline 19 & 1.619 & 1.898 & 243.2 & 0.518 & 230.0 & 0.850 \\
\hline 20 & 1.580 & 2.001 & 252.5 & 0.593 & 237.2 & 0.973 \\
\hline 21 & 1.544 & 2.105 & 260.8 & 0.676 & 244.9 & 1.075 \\
\hline 22 & 1.504 & 2.209 & 265.5 & 0.798 & 253.0 & 1.173 \\
\hline 23 & 1.461 & 2.315 & 275.3 & 0.859 & 259.4 & 1.289 \\
\hline 24 & 1.411 & 2.470 & 283.6 & 1.006 & 270.8 & 1.429 \\
\hline 25 & 1.353 & 2.627 & 292.9 & 1.132 & 280.0 & 1.577 \\
\hline 26 & 1.280 & 2.785 & 299.8 & 1.271 & 286.5 & 1.741 \\
\hline 27 & 1.219 & 2.942 & 304.8 & 1.417 & 292.3 & 1.893 \\
\hline
\end{tabular}

Power-Law Fit

Unloading Compliance

Coeff. C $\quad: 283 \mathrm{~kJ} / \mathrm{m}^{2}$

DC Potential Method

Coeff. C $: 243 \mathrm{~kJ} / \mathrm{m}^{2}$
$\mathrm{J}=\mathrm{C}(\Delta \mathrm{a})^{\mathrm{n}}$

$\mathrm{J}_{\mathrm{Ic}} \quad: 237 \mathrm{~kJ} / \mathrm{m}^{2} \quad$ (13 Data)

Exponent $n: 0.20$

$\mathrm{J}_{\mathrm{Ic}} \quad: 186 \mathrm{~kJ} / \mathrm{m}^{2}$

Fit Coeff. $\mathrm{R}$ : 0.988

(15 Data)

Fit Coeff. R : 0.996 


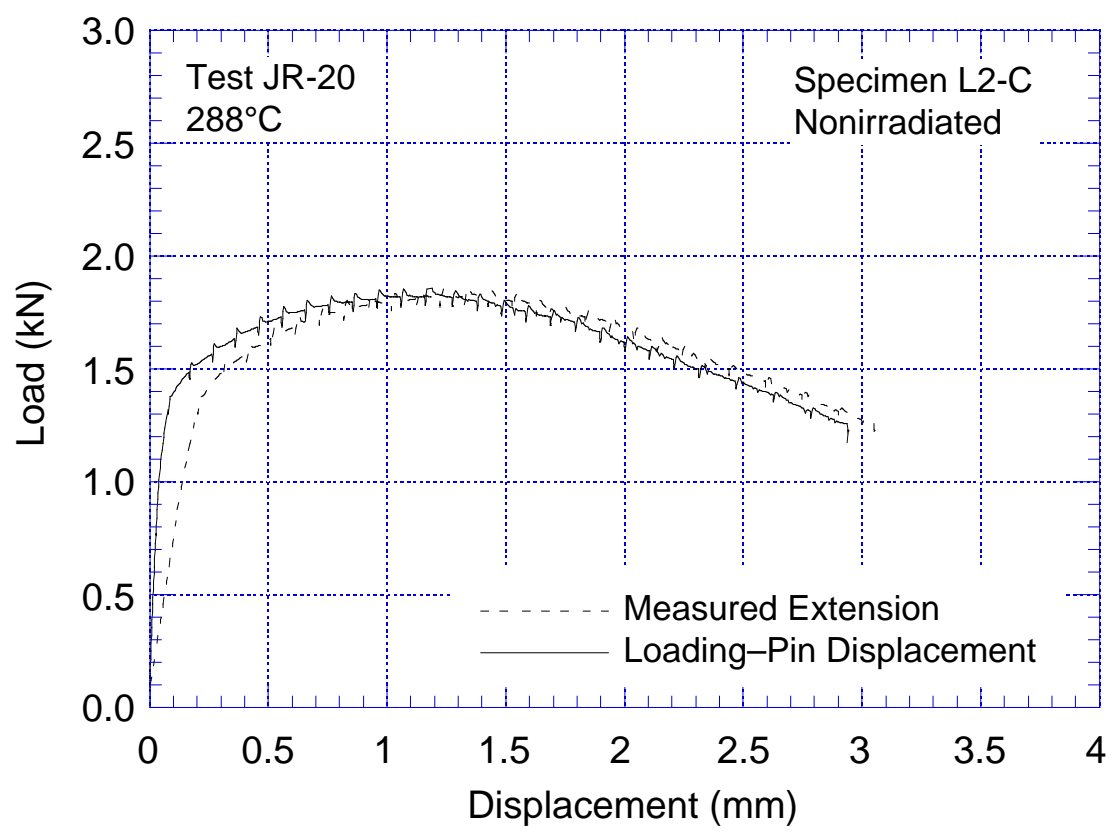

Figure A-18.1. Load-vs.-loadline displacement curve for specimen L20-A of irradiated Type 304 SS tested at $288^{\circ} \mathrm{C}$

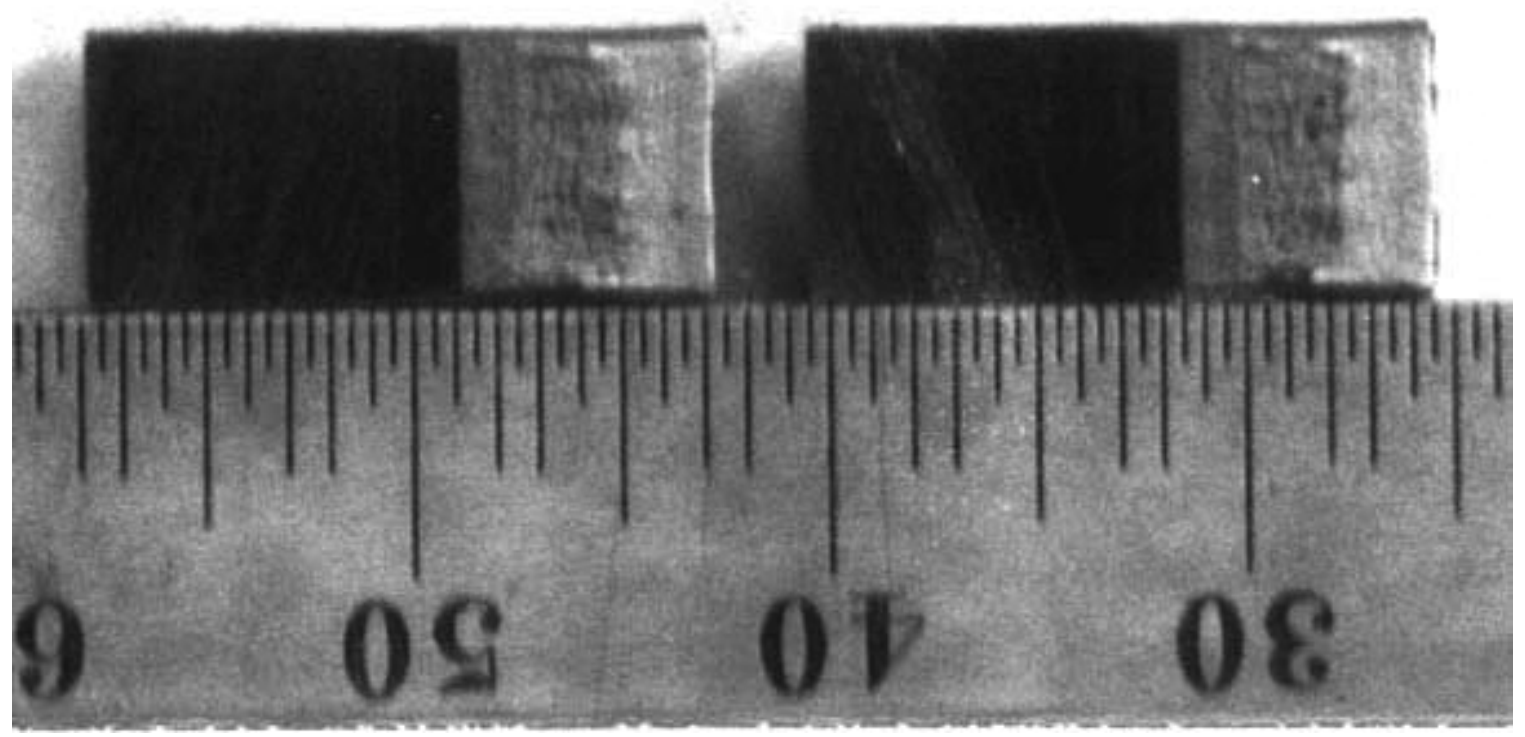

Figure A-18.2. Fracture surface of specimen L20-A tested at $288^{\circ} \mathrm{C}$ 
Table A-19. Test data for specimen L20-B of irradiated Type 304 SS tested at $288^{\circ} \mathrm{C}$

$\begin{array}{ll}\text { Test Number } & : \text { JR-24 } \\ \text { Material Type } & : \text { Type } 304 \mathrm{SS} \\ \text { Aging Temp. } & :- \\ \text { Irradiation Temp. } & : 288^{\circ} \mathrm{C} \\ \text { Thickness } & : 6.51 \mathrm{~mm} \\ \text { Width } & : 11.98 \mathrm{~mm} \\ \text { Modulus E } & : 175 \mathrm{GPa} \\ \text { Initial Crack } & : 7.38 \mathrm{~mm} \\ \text { Final Crack } & : 9.17 \mathrm{~mm} \\ \text { Final Crack } & : 8.08 \mathrm{~mm}\end{array}$

$\begin{array}{ll}\text { Test Temp. } & : 288^{\circ} \mathrm{C} \\ \text { Heat Number } & : \text { L20 } \\ \text { Aging Time } & :- \\ \text { Fluence } & : 0.9 \times 10^{21} \mathrm{n} / \mathrm{cm}^{2} \\ \text { Net Thickness } & : 5.84 \mathrm{~mm} \\ \text { Flow Stress } & : 270.5 \mathrm{MPa} \\ & \\ \text { Init. a/W } & : 0.61 \text { (Measured) } \\ \text { Final a/W } & : 0.76 \text { (Measured) } \\ \text { Final a/W } & : 0.75 \text { (Compliance) }\end{array}$

\begin{tabular}{|c|c|c|c|c|c|c|}
\hline \multirow[b]{2}{*}{ No. } & \multirow{2}{*}{$\begin{array}{c}\text { Load } \\
(\mathrm{kN})\end{array}$} & \multirow{2}{*}{$\begin{array}{c}\text { Deflection } \\
(\mathrm{mm})\end{array}$} & \multicolumn{2}{|c|}{ Unloading Compliance } & \multicolumn{2}{|c|}{ DC Potential Method } \\
\hline & & & $\mathrm{J}\left(\mathrm{kJ} / \mathrm{m}^{2}\right)$ & $\Delta \mathrm{a}(\mathrm{mm})$ & $\mathrm{J}\left(\mathrm{kJ} / \mathrm{m}^{2}\right)$ & $\Delta \mathrm{a}(\mathrm{mm})$ \\
\hline 0 & 0.089 & 0.000 & & & & \\
\hline 1 & 1.300 & 0.080 & 6.5 & 0.237 & 6.5 & 0.006 \\
\hline 2 & 1.453 & 0.169 & 18.9 & 0.152 & 17.1 & 0.016 \\
\hline 3 & 1.529 & 0.265 & 30.2 & 0.155 & 29.3 & 0.028 \\
\hline 4 & 1.596 & 0.361 & 43.7 & 0.126 & 41.9 & 0.040 \\
\hline 5 & 1.648 & 0.459 & 58.7 & 0.041 & 55.2 & 0.054 \\
\hline 6 & 1.685 & 0.556 & 72.5 & 0.015 & 68.9 & 0.067 \\
\hline 7 & 1.717 & 0.656 & 87.4 & 0.027 & 83.2 & 0.080 \\
\hline 8 & 1.741 & 0.756 & 101.7 & 0.040 & 97.7 & 0.093 \\
\hline 9 & 1.754 & 0.857 & 117.1 & 0.027 & 112.4 & 0.107 \\
\hline 10 & 1.769 & 0.958 & 130.1 & 0.082 & 127.1 & 0.119 \\
\hline 11 & 1.774 & 1.059 & 144.7 & 0.101 & 142.1 & 0.132 \\
\hline 12 & 1.780 & 1.160 & 159.9 & 0.104 & 157.0 & 0.146 \\
\hline 13 & 1.775 & 1.275 & 176.7 & 0.120 & 171.1 & 0.234 \\
\hline 14 & 1.759 & 1.379 & 191.6 & 0.136 & 181.6 & 0.339 \\
\hline 15 & 1.734 & 1.482 & 203.5 & 0.200 & 192.3 & 0.432 \\
\hline 16 & 1.708 & 1.586 & 214.2 & 0.277 & 201.9 & 0.542 \\
\hline 17 & 1.692 & 1.688 & 227.3 & 0.310 & 211.0 & 0.651 \\
\hline 18 & 1.666 & 1.793 & 238.6 & 0.372 & 220.9 & 0.747 \\
\hline 19 & 1.619 & 1.898 & 243.2 & 0.518 & 230.0 & 0.850 \\
\hline 20 & 1.580 & 2.001 & 252.5 & 0.593 & 237.2 & 0.973 \\
\hline 21 & 1.544 & 2.105 & 260.8 & 0.676 & 244.9 & 1.075 \\
\hline 22 & 1.504 & 2.209 & 265.5 & 0.798 & 253.0 & 1.173 \\
\hline 23 & 1.461 & 2.315 & 275.3 & 0.859 & 259.4 & 1.289 \\
\hline 24 & 1.411 & 2.470 & 283.6 & 1.006 & 270.8 & 1.429 \\
\hline 25 & 1.353 & 2.627 & 292.9 & 1.132 & 280.0 & 1.577 \\
\hline 26 & 1.280 & 2.785 & 299.8 & 1.271 & 286.5 & 1.741 \\
\hline 27 & 1.219 & 2.942 & 304.8 & 1.417 & 292.3 & 1.893 \\
\hline
\end{tabular}

Power-Law Fit

Unloading Compliance

Coeff. C $\quad: 283 \mathrm{~kJ} / \mathrm{m}^{2}$

DC Potential Method

Coeff. C $: 243 \mathrm{~kJ} / \mathrm{m}^{2}$
$\mathrm{J}=\mathrm{C}(\Delta \mathrm{a})^{\mathrm{n}}$

$\mathrm{J}_{\mathrm{Ic}} \quad: 237 \mathrm{~kJ} / \mathrm{m}^{2} \quad$ (13 Data)

Exponent $n: 0.20$

$\mathrm{J}_{\mathrm{Ic}} \quad: 186 \mathrm{~kJ} / \mathrm{m}^{2}$

Fit Coeff. $\mathrm{R}$ : 0.988

(15 Data)

Fit Coeff. R : 0.996 


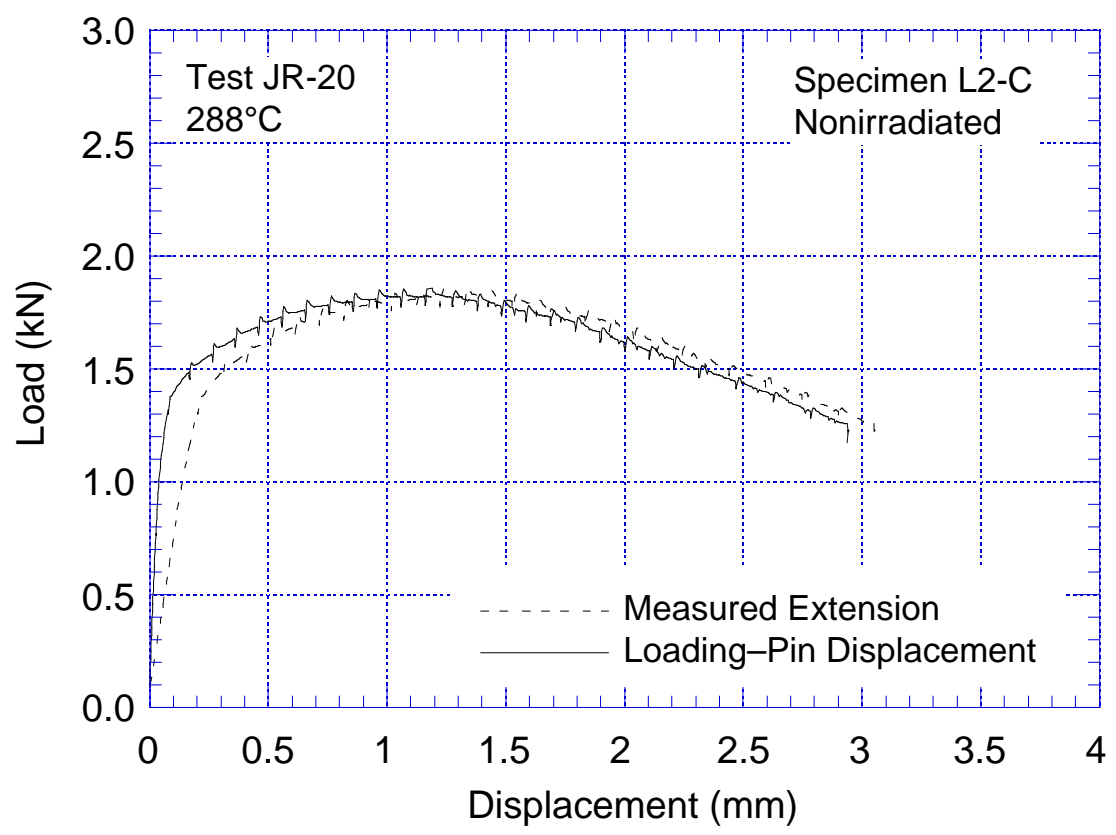

Figure A-19.1. Load-vs.-loadline displacement curve for specimen L20-B of irradiated Type 304 SS tested at $288^{\circ} \mathrm{C}$

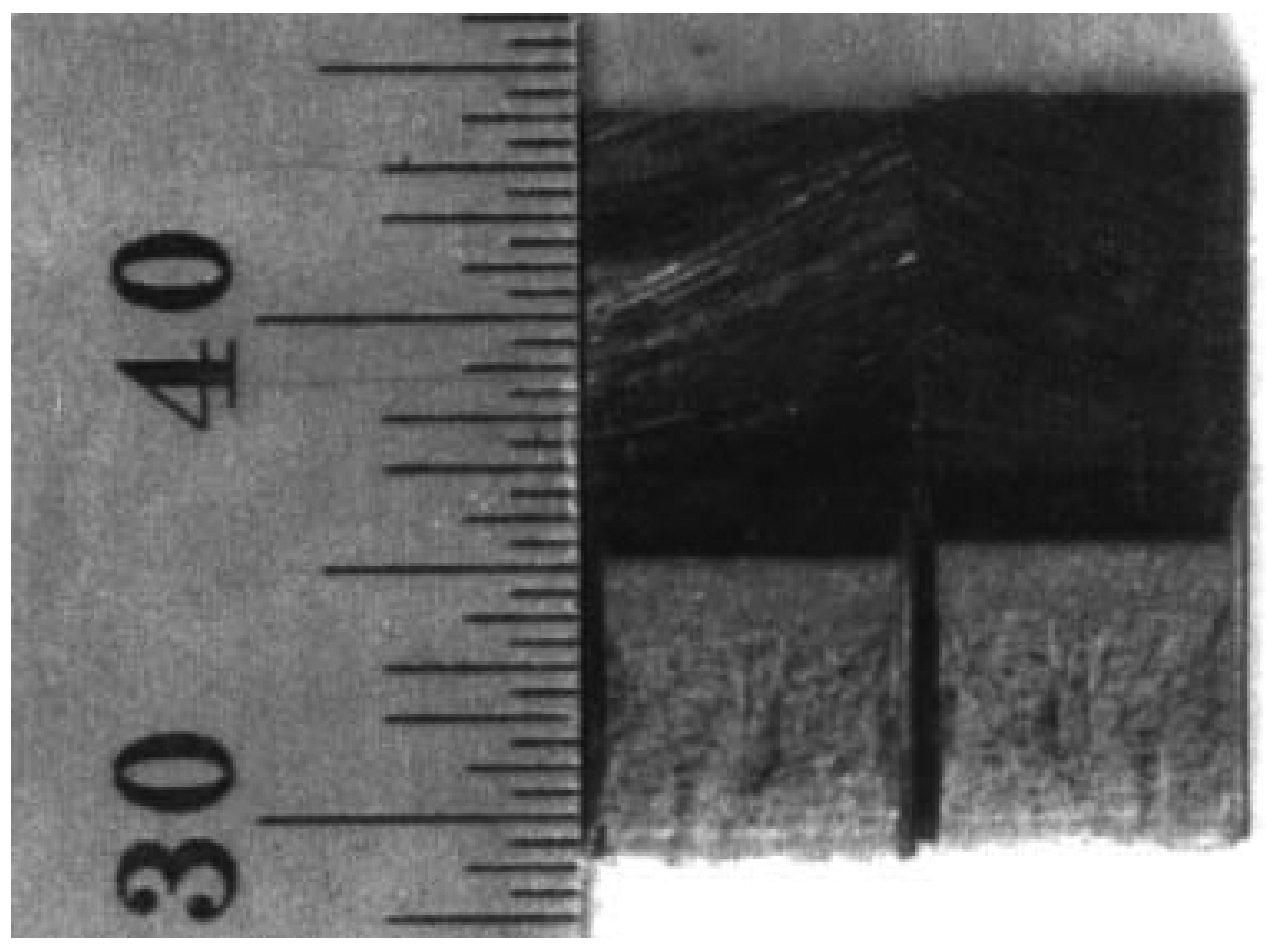

Figure A-19.2. Fracture surface of specimen L20-B tested at $288^{\circ} \mathrm{C}$ 
Table A-20. Test data for specimen L2-A of irradiated Type $304 \mathrm{SS}$ tested at $288^{\circ} \mathrm{C}$

$\begin{array}{ll}\text { Test Number } & : \text { JR-25 } \\ \text { Material Type } & : \text { Type } 304 \mathrm{SS} \\ \text { Aging Temp. } & :- \\ \text { Irradiation Temp. } & : 288^{\circ} \mathrm{C} \\ \text { Thickness } & : 6.51 \mathrm{~mm} \\ \text { Width } & : 11.98 \mathrm{~mm} \\ \text { Modulus E } & : 175 \mathrm{GPa} \\ \text { Initial Crack } & : 7.38 \mathrm{~mm} \\ \text { Final Crack } & : 9.17 \mathrm{~mm} \\ \text { Final Crack } & : 8.08 \mathrm{~mm}\end{array}$

$\begin{array}{ll}\text { Test Temp. } & : 288^{\circ} \mathrm{C} \\ \text { Heat Number } & : \mathrm{L} 2 \\ \text { Aging Time } & :- \\ \text { Fluence } & : 0.9 \times 10^{21} \mathrm{n} / \mathrm{cm}^{2} \\ \text { Net Thickness } & : 5.84 \mathrm{~mm} \\ \text { Flow Stress } & : 270.5 \mathrm{MPa} \\ & \\ \text { Init. a/W } & : 0.61 \text { (Measured) } \\ \text { Final a/W } & : 0.76 \text { (Measured) } \\ \text { Final a/W } & : 0.75 \text { (Compliance) }\end{array}$

\begin{tabular}{|c|c|c|c|c|c|c|}
\hline \multirow[b]{2}{*}{ No. } & \multirow{2}{*}{$\begin{array}{c}\text { Load } \\
(\mathrm{kN})\end{array}$} & \multirow{2}{*}{$\begin{array}{l}\text { Deflection } \\
(\mathrm{mm})\end{array}$} & \multicolumn{2}{|c|}{ Unloading Compliance } & \multicolumn{2}{|c|}{ DC Potential Method } \\
\hline & & & $\mathrm{J}\left(\mathrm{kJ} / \mathrm{m}^{2}\right)$ & $\Delta \mathrm{a}(\mathrm{mm})$ & $\mathrm{J}\left(\mathrm{kJ} / \mathrm{m}^{2}\right)$ & $\Delta \mathrm{a}(\mathrm{mm})$ \\
\hline 0 & 0.089 & 0.000 & & & & \\
\hline 1 & 1.300 & 0.080 & 6.5 & 0.237 & 6.5 & 0.006 \\
\hline 2 & 1.453 & 0.169 & 18.9 & 0.152 & 17.1 & 0.016 \\
\hline 3 & 1.529 & 0.265 & 30.2 & 0.155 & 29.3 & 0.028 \\
\hline 4 & 1.596 & 0.361 & 43.7 & 0.126 & 41.9 & 0.040 \\
\hline 5 & 1.648 & 0.459 & 58.7 & 0.041 & 55.2 & 0.054 \\
\hline 6 & 1.685 & 0.556 & 72.5 & 0.015 & 68.9 & 0.067 \\
\hline 7 & 1.717 & 0.656 & 87.4 & 0.027 & 83.2 & 0.080 \\
\hline 8 & 1.741 & 0.756 & 101.7 & 0.040 & 97.7 & 0.093 \\
\hline 9 & 1.754 & 0.857 & 117.1 & 0.027 & 112.4 & 0.107 \\
\hline 10 & 1.769 & 0.958 & 130.1 & 0.082 & 127.1 & 0.119 \\
\hline 11 & 1.774 & 1.059 & 144.7 & 0.101 & 142.1 & 0.132 \\
\hline 12 & 1.780 & 1.160 & 159.9 & 0.104 & 157.0 & 0.146 \\
\hline 13 & 1.775 & 1.275 & 176.7 & 0.120 & 171.1 & 0.234 \\
\hline 14 & 1.759 & 1.379 & 191.6 & 0.136 & 181.6 & 0.339 \\
\hline 15 & 1.734 & 1.482 & 203.5 & 0.200 & 192.3 & 0.432 \\
\hline 16 & 1.708 & 1.586 & 214.2 & 0.277 & 201.9 & 0.542 \\
\hline 17 & 1.692 & 1.688 & 227.3 & 0.310 & 211.0 & 0.651 \\
\hline 18 & 1.666 & 1.793 & 238.6 & 0.372 & 220.9 & 0.747 \\
\hline 19 & 1.619 & 1.898 & 243.2 & 0.518 & 230.0 & 0.850 \\
\hline 20 & 1.580 & 2.001 & 252.5 & 0.593 & 237.2 & 0.973 \\
\hline 21 & 1.544 & 2.105 & 260.8 & 0.676 & 244.9 & 1.075 \\
\hline 22 & 1.504 & 2.209 & 265.5 & 0.798 & 253.0 & 1.173 \\
\hline 23 & 1.461 & 2.315 & 275.3 & 0.859 & 259.4 & 1.289 \\
\hline 24 & 1.411 & 2.470 & 283.6 & 1.006 & 270.8 & 1.429 \\
\hline 25 & 1.353 & 2.627 & 292.9 & 1.132 & 280.0 & 1.577 \\
\hline 26 & 1.280 & 2.785 & 299.8 & 1.271 & 286.5 & 1.741 \\
\hline 27 & 1.219 & 2.942 & 304.8 & 1.417 & 292.3 & 1.893 \\
\hline
\end{tabular}

Power-Law Fit

Unloading Compliance

Coeff. C $\quad: 283 \mathrm{~kJ} / \mathrm{m}^{2}$

DC Potential Method

Coeff. C $\quad: 243 \mathrm{~kJ} / \mathrm{m}^{2}$
$\mathrm{J}=\mathrm{C}(\Delta \mathrm{a})^{\mathrm{n}}$

$\mathrm{J}_{\text {Ic }} \quad: 237 \mathrm{~kJ} / \mathrm{m}^{2} \quad$ (13 Data)

Exponent $\mathrm{n}: 0.20$

$\mathrm{J}_{\mathrm{Ic}} \quad: 186 \mathrm{~kJ} / \mathrm{m}^{2}$

Fit Coeff. $\mathrm{R}$ : 0.988

(15 Data)

Fit Coeff. $\mathrm{R}$ : 0.996 


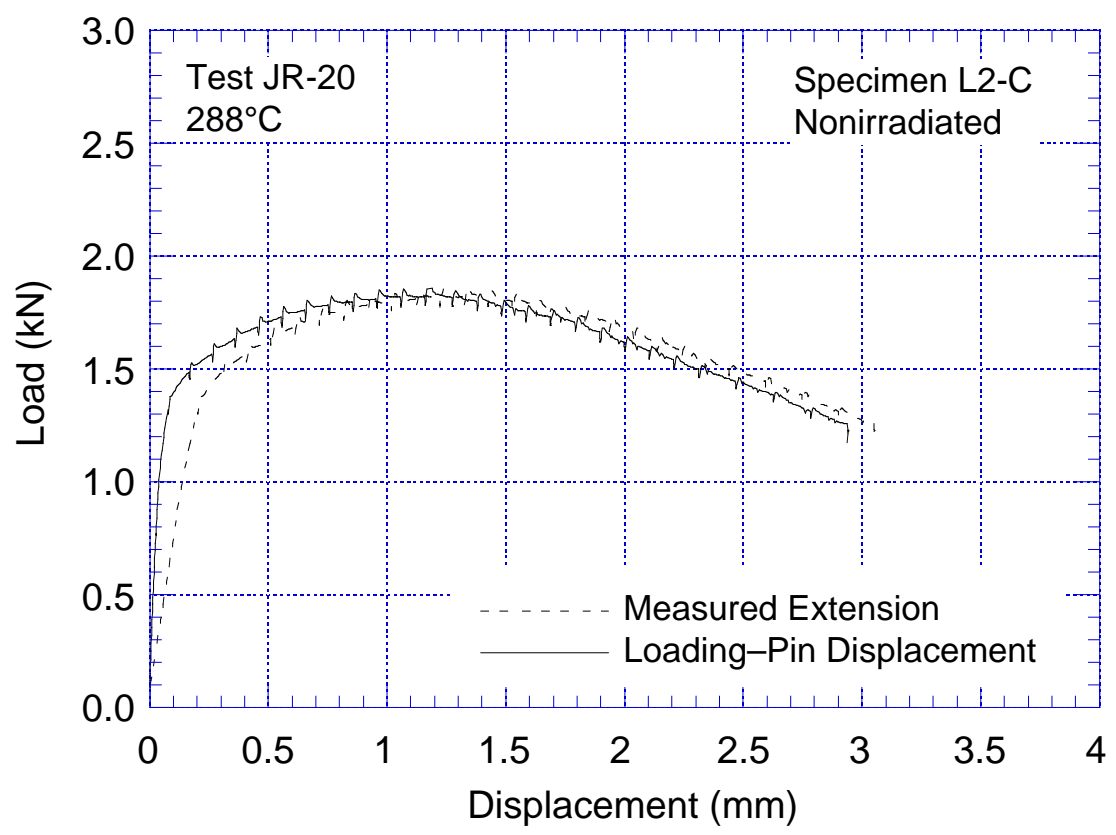

Figure A-20.1. Load-vs.-loadline displacement curve for specimen L2-A of irradiated Type $304 \mathrm{SS}$ tested at $288^{\circ} \mathrm{C}$

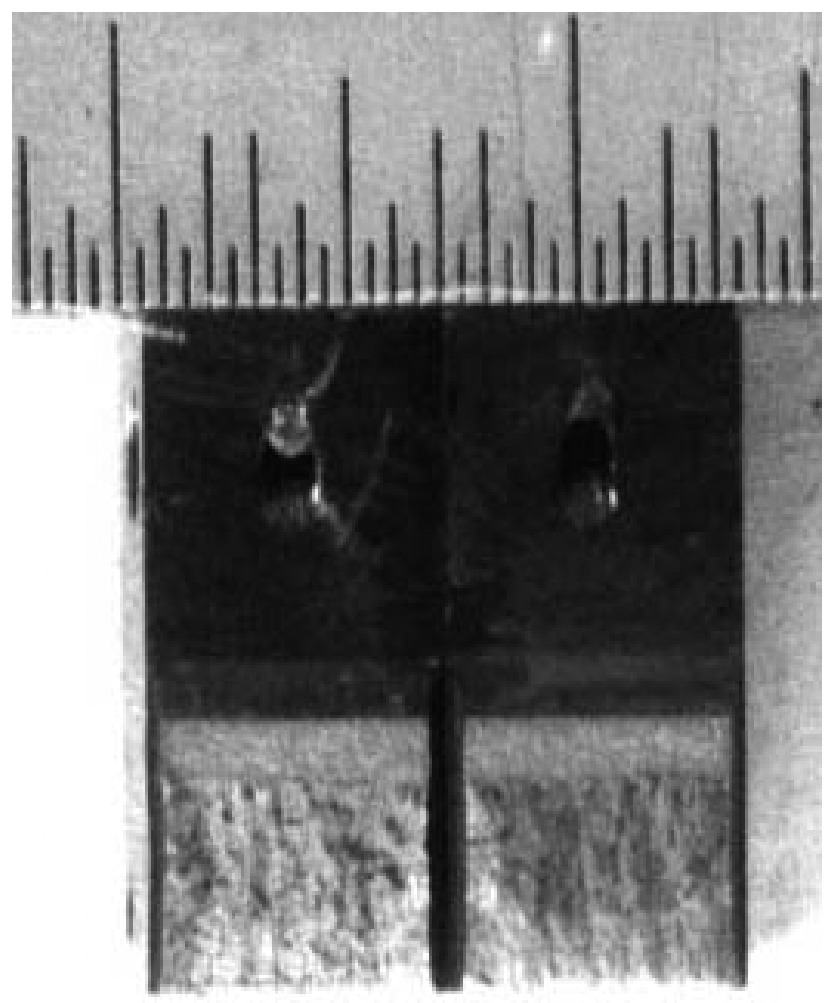

Figure A-20.2. Fracture surface of specimen $L 2-A$ tested at $288^{\circ} \mathrm{C}$ 
NRC FORM 335

(2-89)

NRCM 1102

3201,3202

\section{TITLE AND SUBTITLE}

Fracture Toughness and Crack Growth Rates of Irradiated

Austenitic Stainless Steels

\section{BIBLIOGRAPHIC DATA SHEET}

(See instructions on the reverse)

5. AUTHOR(S)
O. K. Chopra, E. E. Gruber, and W. J. Shack

8. PERFORMING ORGANIZATION - NAME AND ADDRESS (If NRC, provide Division, Office or Region, U.S. Nuclear Regulatory Commission, and mailing address; if contractor, provide name and mailing address.)

Argonne National Laboratory

9700 South Cass Avenue

Argonne, IL 60439

9. SPONSORING ORGANIZATION - NAME AND ADDRESS (If NRC, type "Same as above": if contractor, provide NRC Division, Office or Region, U.S. Nuclear Regulatory Commission, and mailing address.)

Division of Engineering Technology

Office of Nuclear Regulatory Research

U.S. Nuclear Regulatory Commission

Washington, DC 20555-0001

10. SUPPLEMENTARY NOTES

William H. Cullen, Jr., and Carol E. Moyer, NRC Project Managers

11. ABSTRACT (200 words or less)

Austenitic stainless steels (SSs) are used extensively as structural alloys in the internal components of reactor pressure vessels because of their superior fracture toughness properties. However, exposure to high levels of neutron irradiation for extended periods leads to significant reduction in the fracture resistance of these steels. Experimental data are presented on fracture toughness and crack growth rates (CGRs) of austenitic SSs irradiated to fluence levels up to $2.0 \mathrm{x} 10^{21} \mathrm{n} / \mathrm{cm}{ }^{2}(\mathrm{E}>1$ $\mathrm{MeV}$ ) ( $3.0 \mathrm{dpa}$ ) at $288^{\circ} \mathrm{C}$. Crack growth tests were conducted under cycling loading and long hold time trapezoidal loading in simulated boiling water reactor (BWR) environments, and fracture toughness tests were conducted in air. Neutron irradiation at $288^{\circ} \mathrm{C}$ decreases the fracture toughness of the steels; the data from commercial heats fall within the scatter band for the data obtained at higher temperatures. In addition, the results indicate significant enhancement of CGRs of the irradiated steels in normal water chemistry BWR environment; the CGRs for irradiated steels are a factor of 5 higher than the disposition curve proposed for sensitized austenitic SSs. The rates decreased by more than an order of magnitude in low-dissolved-oxygen BWR environment.

12. KEY WORDS/DESCRIPTORS (List words or phrases that will assist researchers in locating this report.)

Fracture Toughness

J-R Curve

Crack Growth Rate

Neutron Irradiation

BWR Environment

Dissolved Oxygen

Austenitic Stainless Steels
3. AVAILABILITY STATEMENT Unlimited

14. SECURITY CLASSIFICATION

(This Page)

Unclassified

(This Report)

Unclassified

15. NUMBER OF PAGES

16.ICE PR 
